\title{
Lokaal en landelijk in Limburg : veranderingen in de Limburgse lokale politiek
}

Citation for published version (APA):

Kuiper, W. (1994). Lokaal en landelijk in Limburg : veranderingen in de Limburgse lokale politiek. [Doctoral Thesis, Maastricht University]. Datawyse / Universitaire Pers Maastricht. https://doi.org/10.26481/dis.19940218wk

Document status and date:

Published: 01/01/1994

DOI:

10.26481/dis.19940218wk

Document Version:

Publisher's PDF, also known as Version of record

\section{Please check the document version of this publication:}

- A submitted manuscript is the version of the article upon submission and before peer-review. There can be important differences between the submitted version and the official published version of record.

People interested in the research are advised to contact the author for the final version of the publication, or visit the DOI to the publisher's website.

- The final author version and the galley proof are versions of the publication after peer review.

- The final published version features the final layout of the paper including the volume, issue and page numbers.

Link to publication

\footnotetext{
General rights rights.

- You may freely distribute the URL identifying the publication in the public portal. please follow below link for the End User Agreement:

www.umlib.nl/taverne-license

Take down policy

If you believe that this document breaches copyright please contact us at:

repository@maastrichtuniversity.nl

providing details and we will investigate your claim.
}

Copyright and moral rights for the publications made accessible in the public portal are retained by the authors and/or other copyright owners and it is a condition of accessing publications that users recognise and abide by the legal requirements associated with these

- Users may download and print one copy of any publication from the public portal for the purpose of private study or research.

- You may not further distribute the material or use it for any profit-making activity or commercial gain

If the publication is distributed under the terms of Article $25 \mathrm{fa}$ of the Dutch Copyright Act, indicated by the "Taverne" license above, 
Produktie: Datawyse I Universitaire Pers Maastricht

\section{CIP GEGEVEINS KONINKLIJKE BIBLIOTHEEK, DEN HAAG}

Kuiper, Wim

Lokaal en landelijk in Limburg : veranderingen in de

Limburgse lokale politiek / Wim Kuiper. - Maastricht :

Universitaire Pers Maastricht. - Ill.

Proefschrift Maastricht. - Met lit. opg. - Met

samenvarting in het Engels.

ISBN 90-5278-128-1

NUGI $654 / 480$

Trefw.: gemeentepolitiek ; Limburg. 


\section{LOKAAL EN LANDELIJK IN LIMBURG}

\section{Veranderingen in de Limburgse lokale politiek}

\section{PROEFSCHRIFT}

ter verkrijging van de graad van doctor aan de Rijksuniversiteit Limburg te Maastricht, op gezag van de Rector Magnifcus, Prof.dr. H. Philipsen, volgens het besluit van het College van Dekanen, in het openbaar te verdedigen op vrijdag, 18 februari 1994 om 16.00 uur

door

WIM KUIPER

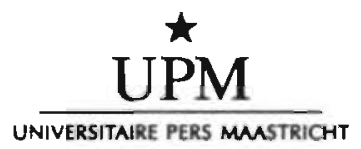




\section{Promotor}

Prof.dr. H. Daalder

(Rijksuniversiteit Leiden)

\section{Co-promotor}

Dr. K.L.L.M. Dittrich

\section{Beoordelingscommissie}

Prof.dr. A.F.A. Korsten

(Open Universiteit Heerlen / Rijksuniversiteit Limburg)(voorzitter)

Prof.dr. G.A. Irwin, Ph.D.

(Rijksuniversiteit Leiden)

Dr. P.W. Tops

(Katholicke Universiteit Brabant)

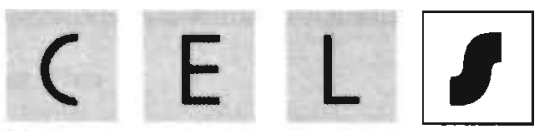

Centrum voor euregionale, provinciale en lokale studies, een samenwerkingsverband van de Open universiteit en METRO, het onderzoeksinstituut van de Faculteit der Rechtsgeleerdheid van de Rijksuniversiteit Limburg 


\section{Inhoudsopgave}

Voorwoord $\ldots \ldots \ldots \ldots \ldots \ldots \ldots \ldots \ldots \ldots$

1. Inleiding . . . . . . . . . . . . . . .

1.1. Aanleiding en doel van het onderzoek . . . . . . . . . . 9

1.2. Probleemstelling en onderzoeksopzet . . . . . . . . . 11

1.3. Onderzoeksmethoden . . . . . . . . . . . . . 13

2. Kenmerken van de Limburgse samenleving . . . . . . . 15

2.1. Staatkundige geschiedenis . . . . . . . . . . . . . 15

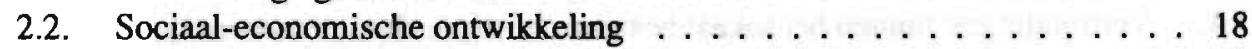

2.3. Urbanisatie en gemeentelijke indeling . . . . . . . . . 20

2.4. Sociaal-culturele ontwikkeling . . . . . . . . . . . . . . 21

2.5. Electorale verhoudingen bij boven-lokale verkiezingen . . . . . . . 29

3. Electorale ontwikkelingen in de Limburgse lokale politiek . . . . 35

3.1. Inleiding . . . . . . . . . . . . . . 35

3.2. De communalististische periode . . . . . . . . . . . . 38

3.3. Achtergronden van de communalistische traditie . . . . . . . 42

3.4. Nationalisering van de Limburgse lokale politiek . . . . . . . . . . . 45

4. Typologie, organisatie en functioneren van lokale politieke

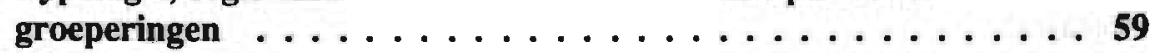

4.1. Inleiding . . . . . . . . . . . . . . . . . 59

4.2. Typen lokale lijsten . . . . . . . . . . . . . . . 60

4.3. Organisatie van lokale en landelijke lijsten . . . . . . . . . . . . 69

4.4. Functioneren van lokale en landelijke lijsten . . . . . . . . . . . . 74

4.5. Recente en te verwachten ontwikkelingen . . . . . . . . . . . . . . 79

5. De band tussen kiezers en politici $\ldots \ldots \ldots \ldots$. . . . . 81

5.1. Inleiding . . . . . . . . . . . . . . 81

5.2. Beschrijving van de onderzoeksresultaten . . . . . . . . . . 82

5.3. Achtergronden van de band tussen kiezers en politici in Limburg . . . . 96 
6. Recrutering van politieke leiders $\ldots \ldots \ldots \ldots$. . . . . 105

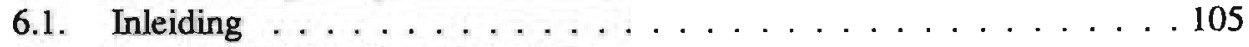

6.2. Beschrijving van de onderzoeksresultaten . . . . . . . . . . . 107

6.3. Achtergronden van recrutering in de Limburgse lokale politiek . . . . . 125

7. Collegevorming in Limburgse gemeenten . . . . . . . . . . 131

7.1. Inleiding . . . . . . . . . . . . . . . . 131

7.2. Collegevorming in de communalistische periode . . . . . . . 133

7.3. Collegevorming in de periode $1982-1990 \ldots \ldots$. . . . . . . 137

7.4. Verhoudingen binnen het lokaal bestuur . . . . . . . . . . . . . . 144

7.5. Achtergronden van collegevorming in Limburgse gemeenten . . . . 147

8. Samenvatting en conclusie $\ldots \ldots \ldots \ldots \ldots \ldots \ldots \ldots$

Appendices . . . . . . . . . . . . . . . . . 157

I. Steekproeftrekking lijsttrekkersenquête . . . . . . . . . . 157

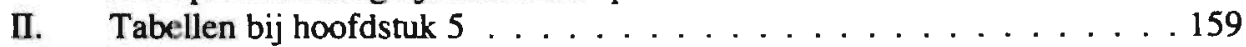

III. Tabellen bij hoofdstuk $6 \ldots \ldots \ldots \ldots$

Summary $\ldots \ldots \ldots \ldots \ldots \ldots$

Literatuur . . . . . . . . . . . . . . . . . 173

Curriculum vitae $\ldots \ldots \ldots \ldots$. . . . . . . . . . . . . . . . . . . . 


\section{Voorwoord}

Hoe komt een niet-Limburger er toe om onderzoek te doen naar de politieke situatie in Limburgse gemeenten? Die vraag heb ik heel wat keren moeten beantwoorden in de loop der jaren. Een bevredigend antwoord heb ik eigenlijk nooit kunnen geven. Ik ben simpelweg door de Rijksuniversiteit Limburg in dienst genomen om mij (onder andere) met onderzoek naar dat onderwerp bezig te houden en ik heb daar nooit spijt van gehad. De Limburgse lokale politiek heeft mij van het begin af aan bijzonder geboeid. Dat lag denk ik mede aan het aanstekende enthousiasme van dr. Karl Dittrich, destijds als universitair hoofddocent werkzaam bij de Maastrichtse Faculteit der Rechtsgeleerdheid. Hij had een groep geïnteresseerde studenten bijeengebracht in de Werkgroep Lokale Politiek en tilde in het verlengde daarvan een compleet onderzoeksproject van de grond.

Enkele jaren later is daar het Centrum voor Euregionale, provinciale en Lokale Studies (CELS) uit voort gekomen, een samenwerkingsverband tussen Open Universiteit en Rijksuniversiteit Limburg, onder leiding van Prof.dr. A. Korsten. Dit proefschriftproject vormde een onderdeel van het onderzoeksprogramma van CELS, getiteld 'De reikwijdte van het sub-nationaal bestuur'.

Van de roemruchte Werkgroep Lokale Politiek maakten de student-assistenten en student-vrijwilligers deel uit, die op allerlei manieren ook een bijdrage aan dit onderzoek hebben geleverd. Ik noem met name Jos Custers, Marc Hermans, Roy Keizers, Marcel Ohlenforst en Marie-Thérese Velraad. Ema Voncken, Annemie Jeukens en met name Elly Peters bedank ik voor de secretariële ondersteuning. Gregor Franssen van de dienst MEMIC ben ik dankbaar voor de ondersteuning bij de steekproeftrekking en de verwerking van enquêtegegevens.

Mijn ex-collega's en collega's die lid waren van de Werkgroep en die voor een prettig en inspirerend werkklimaat borg stonden mogen hier niet onvermeld blijven. Tot die groep behoorden Marcel Boogers, Erik Knippenberg, Mario van Tilburg, Pieter Tops en Rob Welten. Daarnaast bedank ik in het bijzonder Huub Spoormans voor zijn waardevolle commentaren en aanmoedigingen.

Dit boek draag ik tenslotte van harte op aan mijn vrouw Heidi die mij de afgelopen jaren volop gesteund heeft bij de totstandkoming ervan en aan onze kinderen AnneKristin, Vincent en Clemens.

Maastricht, oktober 1993

Wim Kuiper 



\section{Hoofdstuk 1}

\section{Inleiding}

\subsection{Aanleiding en doel van het onderzoek}

Wie ten tijde van gemeenteraadsverkiezingen door het land rijdt en de van gemeentewege ter beschikking gestelde borden bekijkt waarop de diverse partijen hun boodschap uitdragen, constateert een mengeling van 'couleur local' en uniformiteit. Binnen de kaders van de door landelijke partijen vastgestelde logo's, kleuren en slogans, prijken afbeeldingen van plaatselijke coryfeeën. Van noord naar zuid rijdend, neemt de veelkleurigheid van de borden echter zichtbaar toe. In Limburg ziet men er vele waarop de landelijke kaders bijna geheel verdrongen zijn door puur lokaal getinte pamfletten.

Deze oppervlakkige constatering duidt op een apart karakter van de lokale politiek in de provincie Limburg. Een beschouwing van de verkiezingsstatistieken levert een bevestiging van die indruk op. Meer dan in andere provincies wordt de lokale politiek in Limburg gedomineerd door het optreden van plaatselijke politieke groeperingen. De landelijk bekende partijen waren tot voor enkele jaren in de meeste gemeenteraden zelfs in het geheel niet vertegenwoordigd.

Diezelfde statistieken laten echter ook zien dat de lokale lijsten de afgelopen jaren een aanzienlijk aantal zetels kwijt zijn geraakt aan de landelijke lijsten. De verhouding tussen 'lokaal' en 'landelijk' in de Limburgse gemeentepolitiek is drastisch gewijzigd. Er is een proces van nationalisering opgetreden. Deze electorale aardverschuiving is qua omvang vergelijkbaar met de afkalving van de confessionele partijen op landelijk niveau, maar de achtergronden en gevolgen ervan hebben buiten de provincie betrekkelijk weinig aandacht gekregen. In die zin zou men kunnen spreken van een stille revolutie.

De aanleiding tot het onderzoeksproject, waar deze studie een onderdeel van vormt, is zowel de verwondering over de hierboven geconstateerde feiten en de daaruit voortvloeiende nieuwsgierigheid van de onderzoekers naar de oorzaken en achtergronden ervan, als de signalering van een manco in de politicologische literatuur over Nederlandse gemeentepolitiek. De door lokale lijsten gedomineerde politieke systemen die voor lokale politiek in Limburg zo typerend zijn, werden tot voor enige jaren in het politicologisch onderzoek nauwelijks behandeld ${ }^{1}$. 
Dit laatste is niet zo vreemd gelet op enkele specifieke problemen die de afwezigheid of marginale positie van landelijke partijen voor een analyse van de lokale politiek met zich meebrengt. Bij onderzoek dat gericht is op de beleidsuitkomsten in relatie tot de politieke verhoudingen, wordt gewoonlijk gebruik gemaakt van een links-rechts-schaal, zoals die ook voor de partijen op nationaal niveau wordt gehanteerd (bv. Denters, 1987). Weliswaar huldigen plaatselijke afdelingen van landelijke partijen niet noodzakelijkerwijs dezelfde standpunten als de moederpartij en zijn de beleidsthema's die bij het vaststellen van de positie op de links-rechts-schaal gehanteerd worden op lokaal niveau veelal niet relevant, toch kan men de stelling verdedigen dat daarmee ook voor dat niveau een redelijk betrouwbaar beeld wordt verkregen van de globale positie van de plaatselijke partijen ten opzichte van elkaar (Denters, 1987:77).

Hantering van een dergelijke schaal is echter vrijwel onmogelijk wanneer de plaatselijke politieke verhoudingen bepaald worden door lokale groeperingen. Anders dan bij landelijke partijen, duidt de naam van lokale lijsten vaak niet op een bepaalde ideologische profilering. De verschillen tussen dit soort lijsten binnen én gemeente kunnen een heel andere achtergrond hebben. Om vast te stellen waar deze lijsten voor staan, moet men van gemeente tot gemeente nader onderzoek verrichten.

Daarnaast staat het niet op voorhand vast of men lokale lijsten wel als intern homogene politieke groeperingen kan opvatten. Op landelijk niveau is men geneigd om politieke partijen grosso modo als eenheidsactoren op te vatten en dissidentisme als een zeldzame afwijking te zien (bv. De Swaan, 1973: Hfdst. I). In lokale politieke systemen waarin afdelingen van nationale partijen domineren is deze veronderstelling gewoonlijk eveneens plausibel, zij het niet onaangevochten (Tops, 1990:26). Plaatselijke afdelingen van landelijke partijen vormen een schakel van een organisatie die in programmatisch opzicht een duidelijke samenhang vertoont. Bij politieke groeperingen die niet aan een landelijke partij zijn verbonden is een dergelijke aanname echter problematischer, gelet op de afwezigheid van een dergelijk samenbindend element. Dit heeft onder andere gevolgen voor de analyse van de collegevorming in de betreffende gemeenten (Kuiper en Tops, 1989; Tops, 1990). Eén en ander leidt ertoe dat de voor politicologisch onderzoek 'lastige' gemeenten waarin dit soort groeperingen domineren nogal eens buiten beschouwing worden gelaten (bv. Denters, 1985; Denters 1987; Leijenaar en Niemöller 1985; Steunenberg, 1989; Steunenberg 1992). Op die wijze wordt niet alleen een onvolledig beeld verkregen van de lokale politiek in Nederland, maar blifft tevens een vanuit theoretisch oogpunt interessante vergelijkingsmogelijkheid van twee verschillende typen politieke systemen binnen een zelfde juridisch-institutioneel kader onbenut.

1 Een duidelijke uitzondering hierop vormde de studie van Dittrich naar gemeenteraadsverkiezingen in de periode 1966-1974, (Dittrich, 1978). 


\subsection{Probleemstelling en onderzoeksopzet}

Deze studie beoogt de gesignaleerde leemte op te vullen door middel van een primair beschrijvende, exploratieve analyse van de Limburgse lokale politiek. Bij deze onderzoeksdoelstelling past een aantal ruim geformuleerde vraagstellingen met betrekking tot enkele voor de aard en werking van de lokale politiek van belang te achten thema's.

Een eerste cluster van vragen heeft betrekking op de aard en het functioneren van lokale lijsten. Waar staan deze lijsten voor, wat is hun achtergrond en hun positie ten opzichte van landelijke lijsten? Hoe zijn deze lijsten georganiseerd, hoe staat het met de continuïteit ervan en hoe functioneren zij als politieke groepering? Welke verschillen zijn er wat dat betreft te constateren tussen plaatselijke politieke groeperingen en afdelingen van landelijke partijen? Deze vragen komen in hoofdstuk 4 aan de orde.

Ook met betrekking tot de relatie tussen kiezers en politici is de vraag relevant naar verschillen tussen lokale en landelijke lijsten. Op welke wijze binden de lokale groeperingen van oudsher hun kiezers? Brengt de introduktie van landelijke lijsten ook een verandering met zich mee in de relatie tussen raadsleden en burgers? Op deze thema's gaan wij in hoofdstuk 5 nader in.

Een derde onderzoeksterrein betreft de kenmerken van de plaatselijke politieke leiders in relatie tot de wijze van recrutering. Zijn er verschillen tussen de politieke leiders van lokale en landelijke lijsten? Kunnen deze eventuele verschillen in verband worden gebracht met de aard en het functioneren van beide typen lijsten? Dit vormt het onderwerp van hoofdstuk 6.

Tenslotte is het onderzoek in hoofdstuk 7 gericht op de dynamiek van de bestuurlijke verhoudingen, blijkend uit de wijze van collegevorming. Hoe conflictueus of harmonieus verloopt de collegevorming in Limburgse gemeenten waarbinnen de lokale lijsten domineren? Welke veranderingen treden er op wanneer de landelijke lijsten als nieuwe concurrenten voor de bestaande groeperingen gaan optreden?

De behandeling van deze vier kernthema's van het onderzoek levert een beeld op van het karakter van de Limburgse lokale politiek. Deze studie is beperkt tot de 'input'-zijde van het politieke systeem. De consequenties voor de 'output', met name in de vorm van gemeentelijk beleid, blijven buiten beschouwing.

Om de gegevens met betrekking tot de genoemde onderzoeksthema's in een bredere context van de maatschappelijke en electorale verhoudingen en ontwikkelingen in Limburg te plaatsen, gaan aan de vier genoemde hoofdstukken nog twee andere vooraf.

In hoofdstuk 2 staan wij kort stil bij de staatkundige geschiedenis en de sociaal-economische, sociaal-geografische en culturele ontwikkeling van deze provincie. In dit hoofdstuk komt daarnaast de politieke voorkeur van Limburgers bij boven-lokale verkiezingen aan de orde. Deze gegevens zijn van belang voor het verkrijgen van inzicht in de achtergronden van de ontwikkelingen in de Limburgse lokale politiek.

In hoofdstuk 3 wordt aan de hand van verkiezingsstatistieken een beschrijving gegeven van de politieke verhoudingen en electorale ontwikkelingen in Limburg op gemeentelijk niveau, in de periode 1945-1990. Dit levert een beeld op van de afwij- 


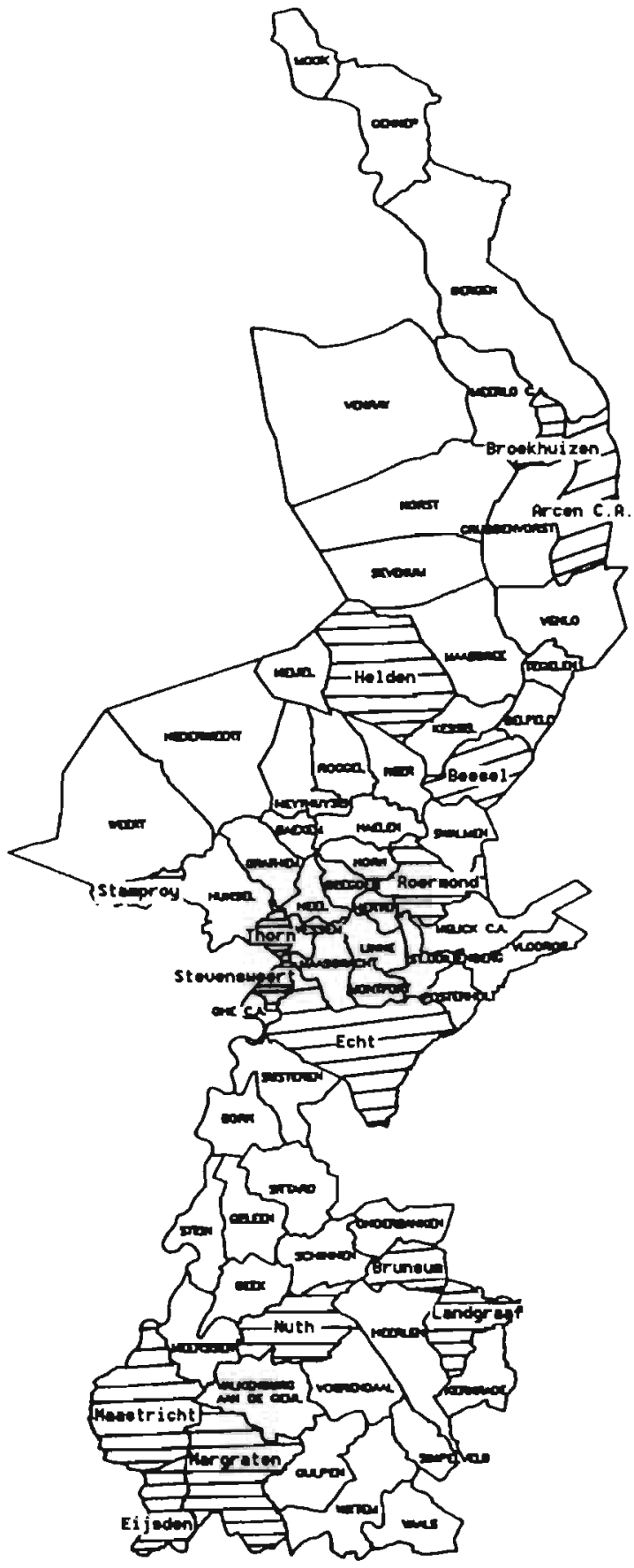

Kaart 1.I. De vijftien steekproefgemeenten van de lijstrekkersenquêtes. 
kingen van de Limburgse situatie ten opzichte van die in de andere provincies, alsmede van het proces van nationalisering in de jaren tachtig.

\subsection{Onderzoeksmethoden}

De belangrijkste bron van gegevens die in deze studie gebruikt wordt, bestaat uit de resultaten van een mondelinge en schriftelijke enquête onder lijsttrekkers bij gemeenteraadsverkiezingen in Limburg. Bij dit eind 1986 en begin 1987 uitgevoerde onderzoek, waren de lijsttrekkers uit vijftien Limburgse gemeenten betrokken. Deze gemeenten zijn geselecteerd op basis van een gestratificeerde steekproef. (Voor nadere gegevens over de steekproeftrekking, zie Appendix I). De betreffende gemeenten zijn: Arcen en Velden, Beesel, Broekhuizen, Brunssum, Echt, Eijsden, Helden, Landgraaf, Maastricht, Margraten, Nuth, Roermond, Stevensweert, Stramproy en Thorn. (Zie kaart 1.1.)

In deze gemeenten werden, voor zover de adressen te achterhalen waren, alle 128 personen die bij de gemeenteraadsverkiezingen van 1982 (c.q. eind 19812) als lijsttrekker waren opgetreden, benaderd met het verzoek om medewerking te verlenen aan een mondelinge enquête. Dertien van de aan die verkiezingen deelnemende lijsten konden om diverse redenen niet worden bereikt. (Deze lijsten bezetten samen in de raadsperiode 1982-1986 overigens slechts 21 van de in totaal 253 raadszetels in de vijftien betrokken gemeenten.)

Van de 105 wel bereikte lijsten, vielen er nog eens zeven af wegens non-respons. (Aan de kort voor de enquête gehouden verkiezingen van 1986, hadden vijf van de betrokken zeven lijsten niet meer deelgenomen, terwijl van de overige twee er slechts één in was geslaagd om een zetel te behalen. In 1982 haalden deze zeven lijsten samen zes zetels.) De 98 lijstvertegenwoordigers die wel bereid waren tot een interview betekenden een hoge respons van ruim negentig procent. ${ }^{3}$ Van deze 98 respontenten waren er 78 die in 1982 als raadslid waren verkozen. De respondenten vertegenwoordigden respectievelijk 55 lokale lijsten en 43 landelijke lijsten. Daarmee werd circa

2 In gemeenten die betrokken waren bij de gemeentelijke herindeling van Zuid-Limburg, vonden de gemeenteraadsverkiezingen niet, zoals elders, op 2 juni 1982, maar vervroegd op 21 oktober 1981 plaats. Waar in de volgende hoofdstukken gesproken wordt over de gemeenteraadsverkiezingen van 1982, worden daaronder ook deze herindelingsverkiezingen van acht maanden daarvoor begrepen, tenzij anders vermeld.

3 Niet in alle gevallen ging het daarbij echter om de persoon die in 1982 lijsttrekker was geweest. In negen gevallen werd de nummer twee van de toenmalige lijst geïnterviewd. Voor zover deze lijsten zetels hadden behaald, betrof het wel steeds een raadslid, in twee gevallen tevens wethouder. Van verschillende van deze lijsten is bovendien bekend dat de lijsttrekker van 1982 op het moment van onderzoek niet meer in functie was. Van de betreffende respondenten nemen wij op grond hiervan aan dat zij binnen hun politieke groepering wel een leidende positie bekleedden. Waar in het vervolg gesproken wordt van lijsttrekkers, worden deze personen daar dan ook mede toe gerekend. 
een zesde, respectievelijk een vijfde deel van de aarı de verkiezingen van 1982 in alle Limburgse gemeenten deelnemende lokale en landelijke lijsten bereikt.

Een aantal maanden na het mondelinge interview ontvingen de respondenten een schriftelijke vragenlijst met nog enkele aanvullende vragen. De respons bij de schriftelijke vervolg-enquête bedroeg bijna zestig procent.

De mondelinge en schriftelijke interviews leverden tal van gegevens op betreffende de vier genoemde onderzoeksthema's. Doordat zowel landelijke als lokale lijsten in het respondentenbestand goed vertegenwoordigd waren, kon op veel onderdelen een vergelijking gemaakt worden tussen beide typen lijsten.

Naast de gegevens van de beide lijsttrekkersenquêtes wordt in deze studie gebruik gemaakt van verkiezingsstatistieken, door anderen uitgevoerde kiezersonderzoeken en case-studies, gegevens ontleend aan notulen van raadsvergaderingen en aan literatuur betreffende de lokale politiek in het algemeen en de lokale politiek in Limburg in het bijzonder. 


\section{Hoofdstuk 2}

\section{Kenmerken van de Limburgse samenleving}

De Limburgse lokale politiek kan niet bestudeerd worden los van de historische en maatschappelijke achtergrond waarbinnen zij gestalte krijgt. In dit hoofdstuk worden daarom enkele saillante kenmerken van de Limburgse omgeving behandeld. Achtereenvolgens staan wij stil bij de staatkundige en sociaal-economische geschiedenis van Limburg, de mate van urbanisatie, de gemeentelijke indeling en de sociaal-culturele ontwikkeling van deze provincie. Aan het eind van dit hoofdstuk worden de electorale ontwikkelingen bij boven-lokale verkiezingen weergegeven die zich in Limburg hebben voorgedaan.

\subsection{Staatkundige geschiedenis}

Het gebied dat nu de Nederlandse provincie Limburg vormt behoorde lange tijd tot de meest omstreden gebieden in Europa. In de tweede helft van de zeventiende eeuw, toen in dit deel van Europa de contouren van de latere nationale staten zich begonnen af te tekenen, was het huidige gebied van de Nederlandse provincie Limburg geenszins een staatkundige eenheid. Deze situatie bleef tot aan het einde van de achttiende eeuw gehandhaafd. (Zie kaarten 2.1 en 2.2.)

Een groot deel van het Noordlimburgse platteland behoorde in de achttiende eeuw tot Pruissisch-Opper-Gelder. Daarnaast behoorden gedeelten van het huidige Noorden Midden-Limburg tot de hertogdommen Gulik en Kleve (waaronder Sittard). Andere plaatsen, als Thom en Stein, maakten als vrije rijksheerlijkheid deel uit van het Duitse Rijk, later de Duitse Bond. Daamaast behoorden verschillende gebieden in Midden- en Noord-Limburg met als centrum de stad Roermond bij de Oostenrijkse Nederlanden (Oostenrijks Gelderland). Een klein gedeelte van Zuid-Limburg, tenslotte, maakte als graafschap Loon deel uit van het prinsbisdom Luik.

De vestingstad Venlo, het ambt Montfort en enkele dorpen in de omgeving werden sinds 1716 bestuurd door de Staten-Generaal, (Staats Opper-Gelder). Ook de stad

- Maastricht met toebehoren werd (al sinds 1632) bestuurd door de Staten-Generaal, tredende in de rechten van de Hertog van Brabant, maar in condominium met de 


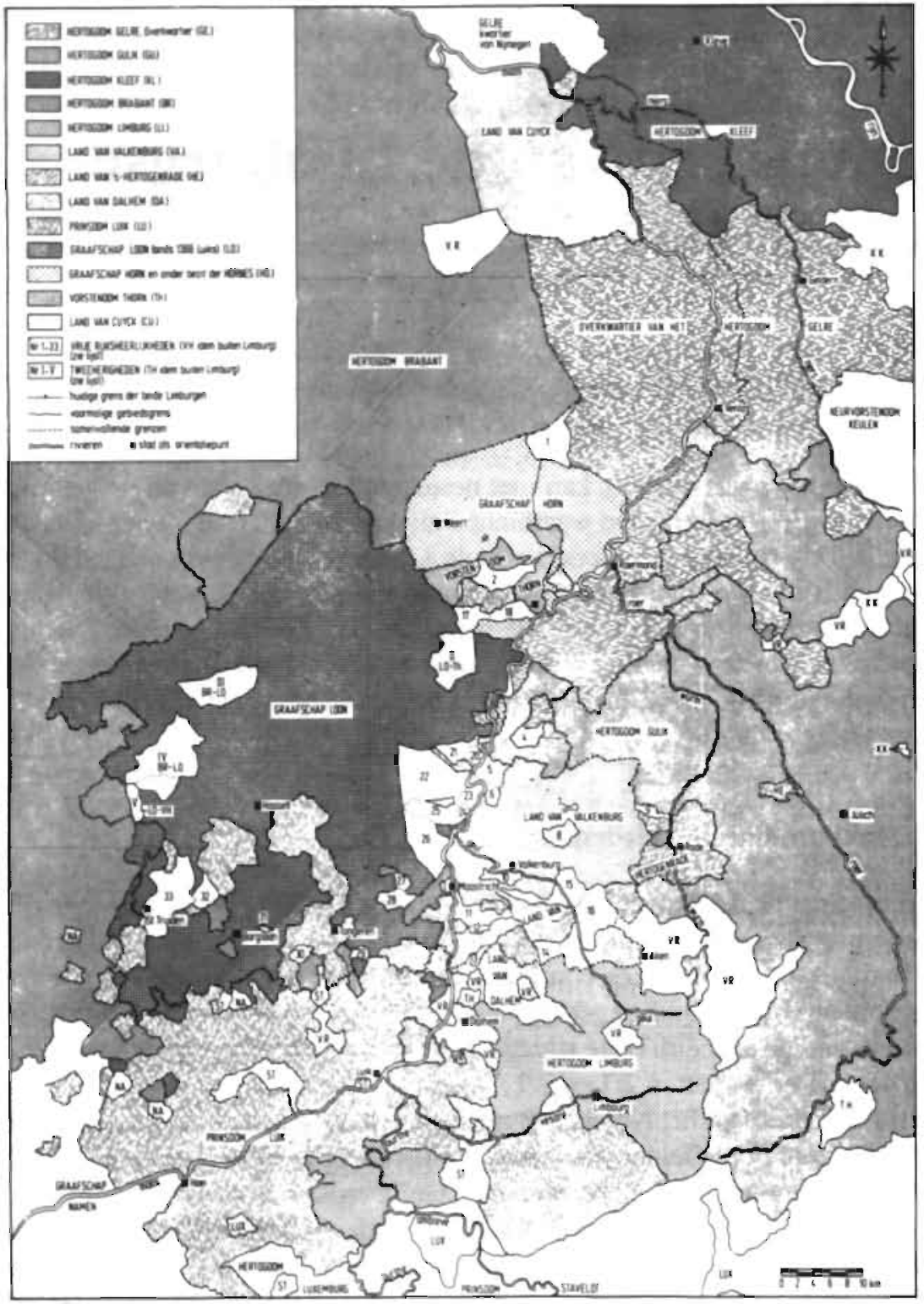

Kuart 2.1. De stautkundige indeling van het grondgebied van de huidige provincie Limburg in 1543. 


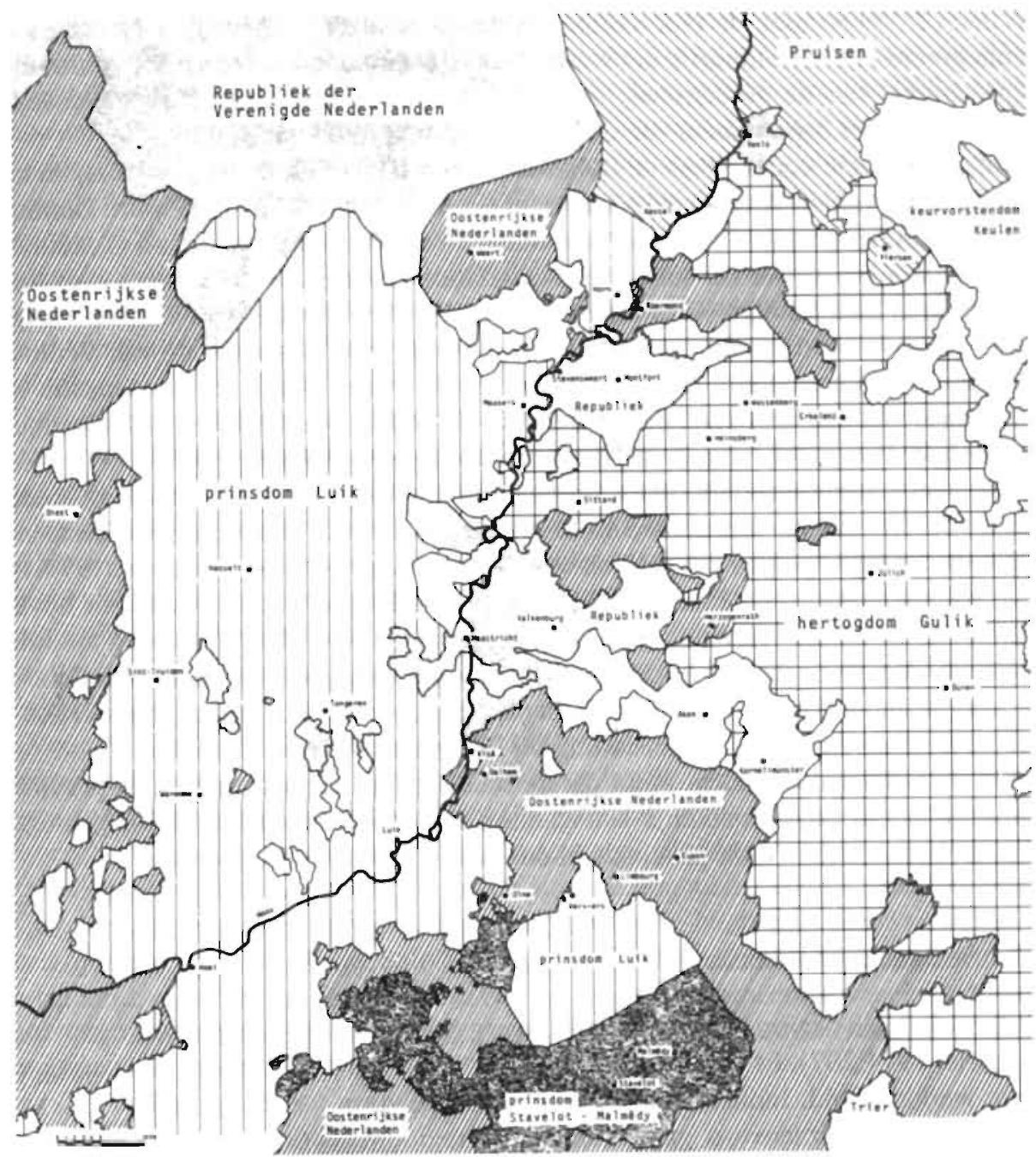

Kaart 2.2. De staatkundige indeling van het grondgebied van de huidige provincie Linhburg in 1785.

prins-bisschop van Luik. Enkele andere plaatsen in Zuid-Limburg, zoals Valkenburg, Gulpen en Vaals, samen de Staatse landen van Overmaze vormend, maikten voorafgaand aan de Franse tijd, eveneens deel uit van de Generaliteitslanden (Fockema Andeae, 1962: 78-85).

De Franse tijd (1794-1815) maakte een einde aan de fragmentatie van het gebied. In het departement van de Nedermaas waren zowel het huidige Belgisch als Nederlands Limburg vrijwel compleet samengevoegd (Nuyens, 1956). Bij het Verdrag van 
Wenen (1815) werden de Noordelijke en de voormalige Oostenrijkse Nederlanden geïntegreerd in het Koninkrijk der Nederlanden. Daarbinnen verkreeg het voormalige departement van de Nedermaas, samen met het aan het Koninkrijk toegewezen gedeelte van het departement van de Roer, de naam provincie Limburg.

Deze provincie koos tijdens de Belgische opstand in 1830, de Belgische zijde, met uitzondering van de vestingstad Maastricht (Lokin, 1989:18). In 1839 werd Limburg echter definitief gesplitst in een bij Nederland en een bij België behorend gedeelte. In dat jaar werden zowel de status als Nederlands gebied, als de grenzen van deze provincie in haar huidige vorm volkenrechtelijk in het Verdrag van Londen vastgelegd. Tevens werd bepaald dat Nederlands Limburg (met uitzondering van Venlo en Maastricht) als hertogdom lid zou worden van de Duitse Bond, ter compensatie van het verlies van een deel van het eveneens tot de Duitse Bond behorende Luxemburg aan België. Pas in 1867 kwam aan dit lidmaatschap een einde.

Dat veel Limburgers zich op dat moment en nog lange tijd daarna niet erg Nederlands voelden, bleek onder andere uit de tot aan het eind van de vorige eeuw bestaande separatische bewegingen die pleitten voor aansluiting bij België (Alberts, 1974:191 e.v.; Knippenberg en De Pater, 1988:26 e.v.). Van Belgische zijde werden er bovendien tot ná de Eerste Wereldoorlog nog aanspraken op Nederlands Limburg tot uiting gebracht. Aan de oostkant van de provincie bestond daamaast een sterke oriëntatie op de aangrenzende Duitse gebieden. Zo bepleitte een delegatie Limburgers in 1848 in het parlement van Frankfurt aansluiting bij Duitsland (Venner, 1989:8).

Uit dit beknopte overzicht blijkt dat de staatkundige begrenzing van de provincie Limburg pas in een betrekkelijk laat stadium een definitief karakter heeft gekregen. Wat dit betreft neemt deze provincie in ons land een bijzondere positie in.

\subsection{Sociaal-economische ontwikkeling}

Tot het eind van de vorige eeuw bleef Limburg een voomamelijk agrarische provincie (Alberts, 1974:207). Er was bovendien in de vorige eeuw sprake van een permanent hoge werkloosheid. Industriële ontwikkeling in de vorm van het grootbedrijf kwam pas laat en moeizaam op gang. Alleen de regio Maastricht vormde hierop een uitzondering met grootschalige metaalnijverheid en keramische en glasverwerkende industrie. In Roermond ontstond enige textiel- en papierindustrie die echter al in het begin van deze eeuw onrendabel bleek. Aan het eind van de negentiende eeuw voltrok zich vooral in de regio Venlo-Tegelen een proces van sterke industriële groei, mede als gevolg van de verbetering van de infrastructuur. De industrialisatie is in de twintigste eeuw echter in nagenoeg alle sectoren gestaag toegenomen. De ontwikkeling van de mijnbouw vormde in Zuid-Limburg een belangrijke groei-impals. De Mijnstreek maakte aan het begin van deze eeuw een stormachtige ontwikkeling door. In korte tijd werden agrarische gemeenten omgevormd tot stedelijke centra. Om een indruk te geven van het tempo van de groei: in 1900 werkten circa duizend personen in de mijnbouw, aan het eind van de jaren twintig waren dat er veertigduizend (Alberts, 1974:236). 
Aangezien de economische structuur in dit gebied voornamelijk op mijnbouw was georiënteerd kwamen de mijnsluitingen in de jaren zestig bijzonder hard aan. Door deze mijnsluitingen gingen direkt 45.000 en indirekt nog eens circa 30.000 arbeidsplaatsen verloren, ofwel bijna 30 procent van de toenmalige totale werkgelegenheid in het op basis van de mijnsluiting vastgestelde herstructureringsgebied Zuid-Limburg (Van de Vooren en Hanraets, 1990:30). De algemene economische stagnatie in de periode 1973-1982 zorgde daamaast voor een aantasting van de werkgelegenheid in andere bedrijfstakken als de metaalnijverheid en confectie-industrie, terwijl de animo om nieuwe bedrijvigheid op te zetten gering was. Ook het andere traditionele centrum van industrie in Zuid-Limburg, de regio Maastricht, werd sterk getroffen door deze recessie.

In het kader van het regionaal economisch beleid heeft de rijksoverheid tot in het begin van de jaren negentig op verschillende manieren geprobeerd om de Zuidlimburgse economie te stimuleren. De van overheidswege geïnitieerde ontwikkeling van onder andere de transportmiddelen- en chemische industrie (respectievelijk Volvo en DSM) en de groei van de dienstensector, onder meer door de vestiging van enkele overheidsinstellingen (zoals het Algemeen Burgerlijk Pensioenfonds, het Centraal Bureau voor de Statistiek, de Open Universiteit en de Rijksuniversiteit Limburg), zorgden voor een gestage groei van het aantal arbeidsplaatsen (Van der Linden en Ruijters, 1990).

Voor de provincie als geheel is er in 1988 een einde gekomen aan de 'regionale component' in de werkloosheid. Vanaf dat jaar lag de Limburgse werkloosheid niet langer boven het landelijk gemiddelde. Dit resultaat wordt voor een belangrijk deel toegeschreven aan het genoemde beleid, dat na een moeizame start met aanvankelijk gebrekkige resultaten aan het einde van de jaren tachtig toch duidelijk vruchten begon af te werpen (Van de Vooren en Hanraets, 1990:48). Niettemin bleef zowel in de oostelijke mijnstreek als in de regio Maastricht de werkloosheid boven het provinciaal en landelijk gemiddelde (Derks, 1990: 60). In een aantal gemeenten was in de tweede helft van de jaren tachtig zelfs meer dan twintig procent van de beroepsbevolking werkloos.

\section{Samenstelling beroepsbevolking}

Als - morfologisch gezien - primair agrarische streken kunnen het Zuidlimburgse heuvelland en Noord- en Midden-Limburg ten westen van de Maas worden beschouwd. Ook in deze streken is echter het aandeel van de agrarische sector in de beroepsbevolking sterk gedaald en hebben velen werk gevonden in de aangrenzende stedelijke gebieden dan wel in de meer kleinschalige dienstverlening en nijverheid in de eigen gemeente.

Evenals elders in het land geldt voor Limburg dat de sectoren zakelijke en overige dienstverlening een steeds groter deel van de beroepsbevolking omvatten. Zoals in tabel 2.1 is weergegeven, was in 1991 ruim 60 procent van de Limburgse beroepsbevolking in de zakelijke en overige dienstensector werkzaam, tegenover 37 procent in 1960. Het aandeel van de sector nijverheid en delfstoffenwinning daalde in dezelfde periode van 54 procent naar 33 procent. De landbouwsector tenslotte verschafte in 
Tabel 2.1. Beroepsbevolking naar bedrijfstak in Limburg (Lb.) en Nederland (Nl.), in 1960, 1971, 1977 en 1991.

\begin{tabular}{|c|c|c|c|c|c|c|c|c|}
\hline \multirow[b]{2}{*}{ bedrijfstak } & \multicolumn{2}{|c|}{1960} & \multicolumn{2}{|c|}{1971} & \multicolumn{2}{|c|}{1981} & \multicolumn{2}{|c|}{1991} \\
\hline & $\mathrm{Lb}$ & NL & $\mathrm{Lb}$ & $\mathrm{Nl}$ & $\mathrm{Lb}$ & $\mathrm{N!}$ & $\mathrm{Lb}$ & $\mathrm{NI}$ \\
\hline landbouw & 9 & 11 & 6 & 7 & 5 & 5 & 5 & 5 \\
\hline $\begin{array}{l}\text { nijverheid en } \\
\text { delfstoffenwinning }\end{array}$ & 54 & 42 & 47 & 39 & 38 & 31 & 33 & 30 \\
\hline zakelijke dienstverl. & 17 & 23 & 26 & 31 & 29 & 33 & 31. & 24 \\
\hline overige dienstverl. & 20 & 24 & 21 & 23 & 28 & 31 & 31 & 41 \\
\hline Totaal & 100 & 100 & 100 & 100 & 100 & 100 & 100 & 100 \\
\hline
\end{tabular}

Bron: CBS, 1967, 1982, 1985, 1992

1991 werk aan 5 procent van de Limburgse beroepsbevolking. In 1960 was dat nog 9 procent (CBS, 1967; CBS, 1992).

In vergelijking met de Nederlandse gemiddelden blijkt in Limburg lange tijd een relatief zeer groot deel van de beroepsbevolking werkzaam geweest te zijn in de nijverheids- en delfstoffenwinningssector. Het verschil met het landelijk gemiddelde was in 1991 echter vrijwel geheel verdwenen. De omvang van de sector zakelijke dienstverlening lag in Limburg daarentegen traditioneel beduidend onder het landelijk gemiddelde; in 1991 was er echter sprake van een positief verschil ten opzichte van dat gemiddelde. De groei in de sector overige dienstverlening bleef in Limburg aan het eind van de onderzoeksperiode sterk achter bij de landelijke ontwikkeling.

De verdeling van de beroepsbevoking over de drie sectoren landbouw, nijverheid en diensten (als geheel) week in Limburg in 1991 niet sterk meer af van het landelijke beeld.

\subsection{Urbanisatie en gemeentelijke indeling}

Omstreeks 1815 woonden er in het gebied van het huidige Nederlands Limburg ongeveer 155.000 personen. De verstedelijking was gering. Op grond van hun omvang ${ }^{l}$ kunnen in die tijd als steden worden beschouwd: Maastricht (circa $18.000 \mathrm{inw}$.), Venlo (5.000 inw.), Roermond (4.000 inw.), Sittard en Kerkrade (beide 3.000 inw.) (Alberts, 1974:146). In deze steden samen woonde ruim 20 procent van de Limburgers.

1 Dit criterium wijkt dus af van hetgeen destijds als maatstaf voor de (juridische) kwalificatie als stad werd gehanteerd. 
Ook aan het einde van de vorige eeuw was de urbanisatie nog beperkt tot de genoemde steden. Het provinciale bevolkingsaantal was in 1880 gegroeid tot 240.000 inwoners (Alberts, 1974:207). De ontwikkeling van de mijnbouw zorgde nadien voor een snelle toename van het inwonertal door immigratie en voor een sterke urbanisatie in de Mijnstreek. Daamaast was evenals elders sprake van een tot in de jaren zestig gestaag oplopend en daama weer dalend geboorten-overschot. In 1947 bedroeg het aantal inwoners van de provincie Limburg 684.000, in 1990 ruim een nniljoen.

Ruim de helft van de Limburgse bevolking is thans geconcentreerd in elf stedelijke gemeenten, met een inwonertal van meer dan 30.000. Maastricht is daarvan de grootste met circa 117.000 inwoners, gevolgd door Heerlen (94.000 inw.), Venlo in Noord-Limburg (63.000 inw.) en Kerkrade in de Mijnstreek (53.000 inw.). Zeven andere stedelijke gemeenten hebben een inwonertal tussen de dertig en vijftigduizend inwoners: Brunssum, Geleen, Landgraaf en Sittard in de Mijnstreek; Weert en Roermond in Midden-Limburg en Venray in Noord-Limburg.

In 1945 waren er in Limburg 111 gemeenten. Door de opheffing van één gemeente in 1958 en zes gemeenten in 1970, daalde dat aantal tot 104. Van deze gemeenten waren er 79 die een inwonertal hadden van 10.000 of minder; 58 gemeenten zelfs minder dan 6.000. In 1981 werd in Zuid-Limburg een gemeentelijke herindeling doorgevoerd. Van de voorheen 58 gemeenten in dit deel van de provincie, bleven er slechts 23 over. In Midden-Limburg vond in 1990 eveneens een gemeentelijke herindeling plaats. Daar werd het aantal gemeenten van 28 naar 15 teruggebracht. Het totaal aantal Limburgse gemeenten bedroeg daama nog 56. (Zie bijgevoegde kaarten 2.3, 2.4, 2.5 en 2.6.) Op het moment van afsluiting van deze studie werd een beperkte herindeling in Noord-Limburg voorbereid.

Dergelijke schaalvergrotende ingrepen hebben uiteraard belangrijke gevolgen voor de lokale politiek. Hieraan zal in het vervolg van deze studie nadere aandacht worden besteed.

\subsection{Sociaal-culturele ontwikkeling}

De sociaal-culturele ontwikkeling van Limburg onderging lange tijd slechts in beperkte mate invloed vanuit het centrum van Nederland. De geografische afstand ten opzichte van Holland was relatief groot en het duurde lang voordat goede spoor- en wegverbindingen hierin veranderingen brachten (Knippenberg en De Pater, 1988:57). Alberts merkt hierover op:

"De uiterst moeizame verwezenlijking van een spoorwegverbinding van de Limburgse steden met het centrum van Nederland was symptomatisch voor de moeizame integratie van Nederlands Limburg in het Koninkrijk der Nederlanden" (Alberts, 1974:216).

Gelet op de staatkundige geschiedenis van Limburg hoeft het niet te verbazen dat er rond de eeuwwisseling van een sterk nationaal gevoel nauwelijks sprake was (Alberts, 1974:157). 


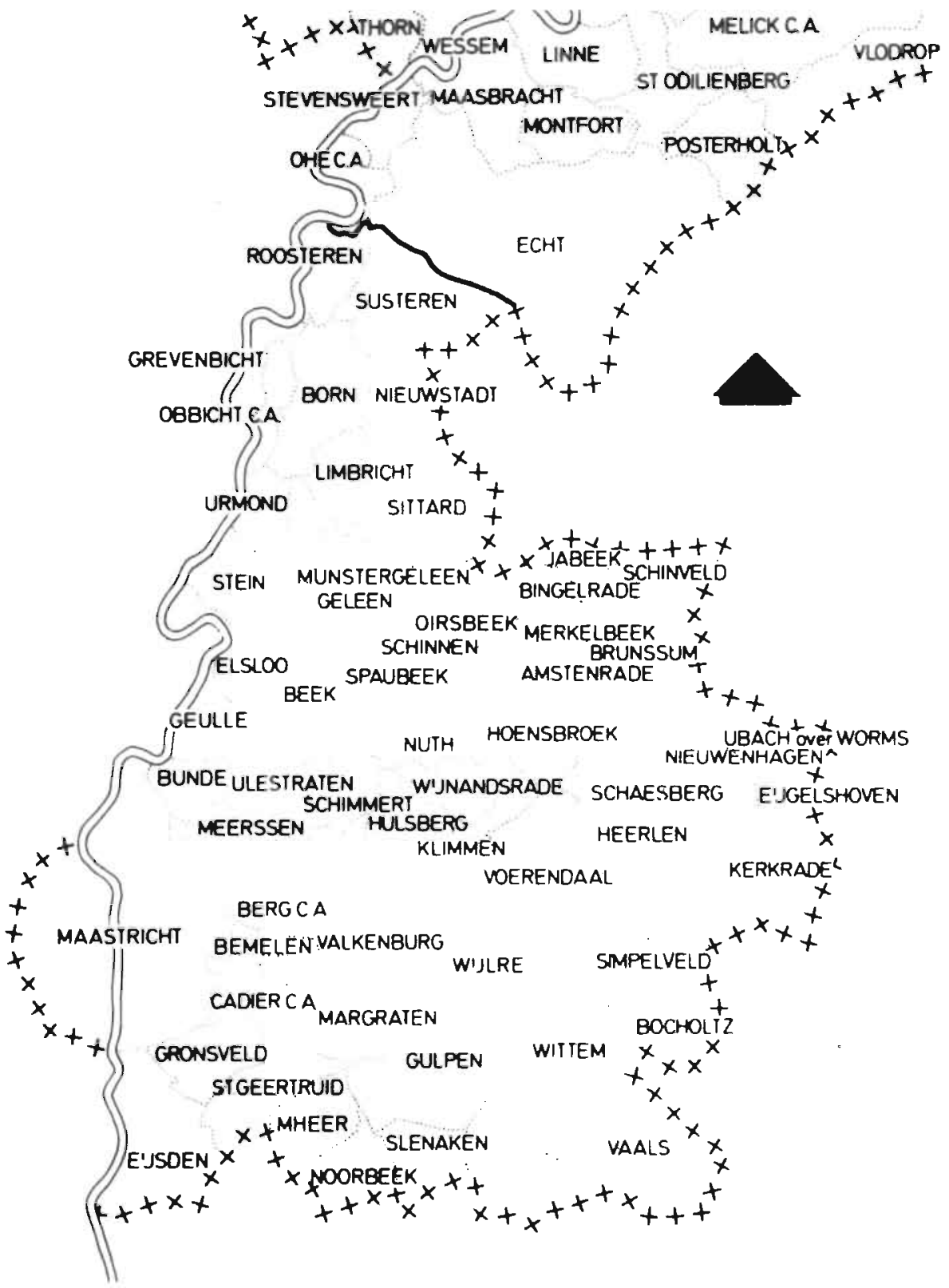

Kaart 2.3. De gemeentegrenzen van Zuid-Limburg tussen 1970 en 1982. 


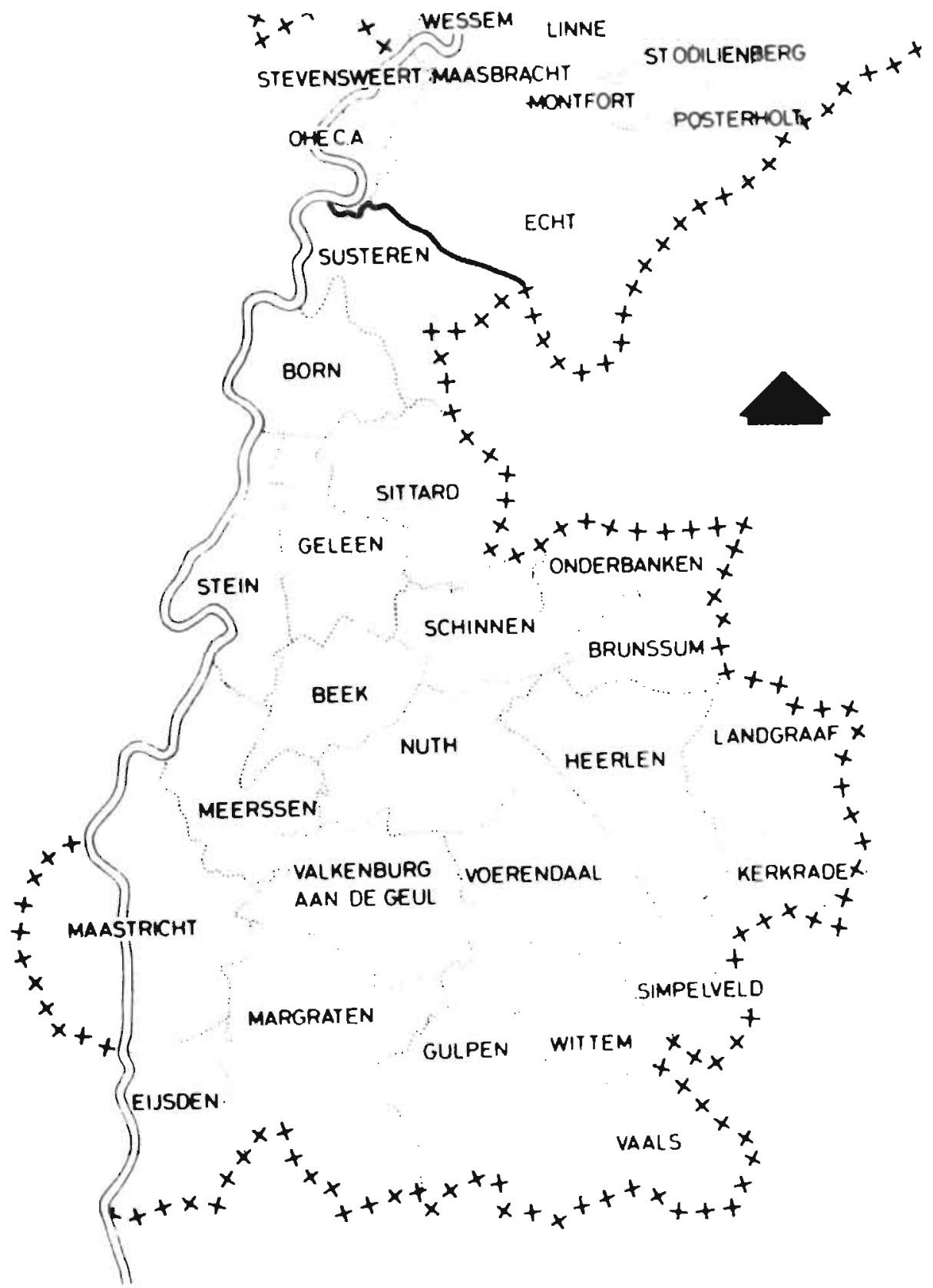

Kaarl 2.4. De gemeentegrenzen van Zuid-Limburg na de herindeling van 1-1-1982. 


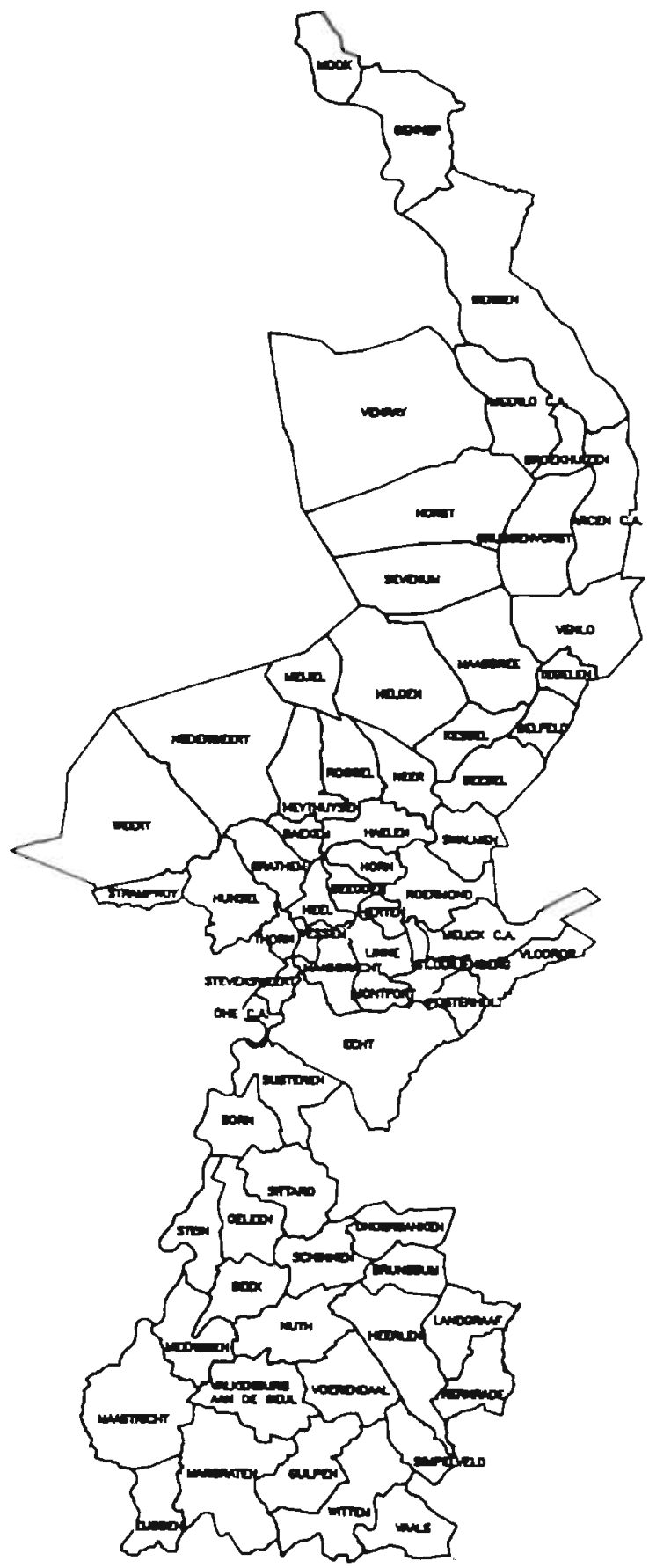

Kaart 2.5. De gemeentegrenzen van de provincie Limburg tussen 1982 en 1990. 


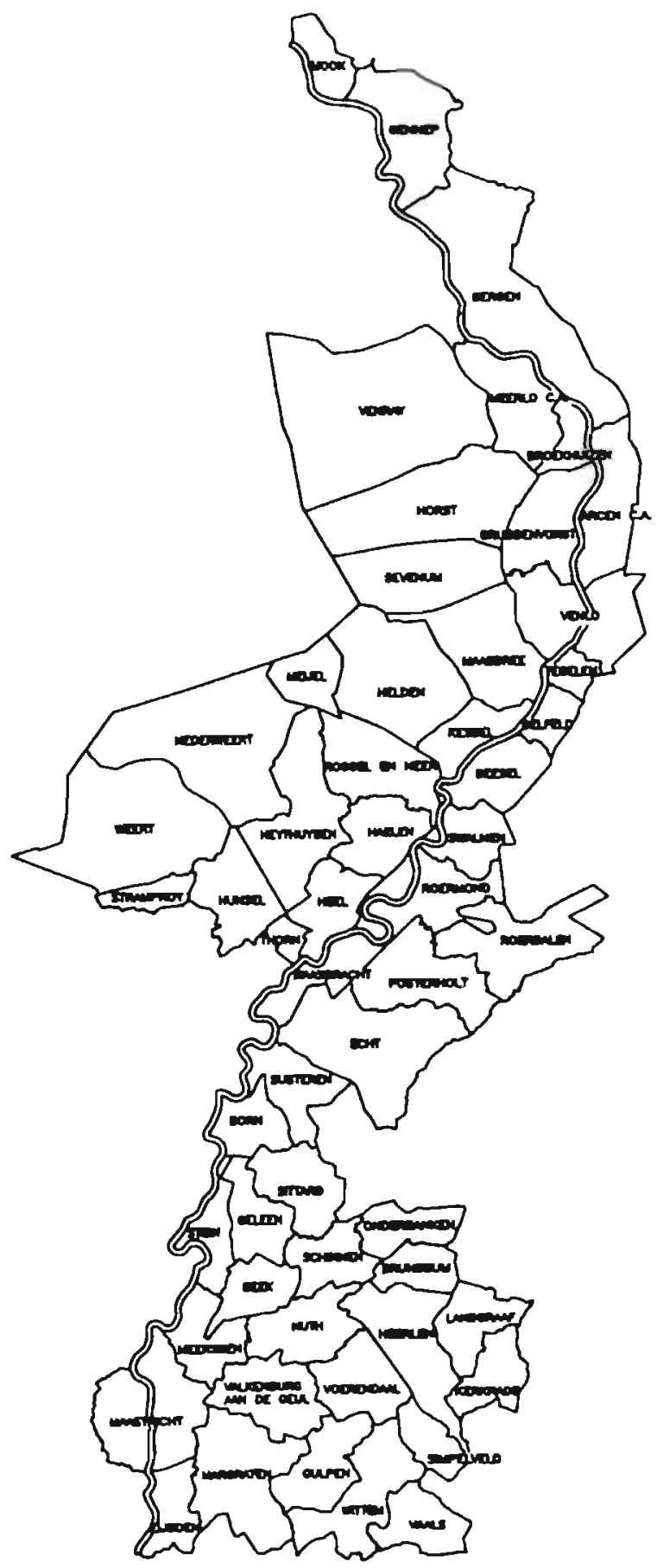

Kaart 2.6. De gemeentegrenzen van de provincie Limburg na de herindeling van 14-9-1990. 
Ook een oriëntatie op de provincie Limburg leek bij veel inwoners aanvankelijk niet aanwezig. Een situatie die tot in onze tijd lijkt voort te duren, gelet op de door verschillende auteurs aangeduide primaire gerichtheid op het eigen dorp of de eigen buurt, ook wel aangeduid als 'lokalisme' (Vellinga, 1975:23; Dittrich, 1978:116-118; Soeters en Felling, 1990:289).

Het is aannemelijk dat deze lokale gerichtheid - die ongetwijfeld in meer regio's in ons land zichtbaar was en is - in Limburg nog steeds een eigen dimensie heeft in de vorm van een zekere aversie tegenover 'Holland' en 'Hollanders', al lijkt deze af te nemen. Het bestaan van de nodige vooroordelen en zegswijzen vormen sporen van een dergelijke aversie. De sterk van het Noord-Nederlands afwijkende streektalen, waarin de invloeden van het naburige Vlaamse, Waalse en Duitse taalgebied duidelijk merkbaar zijn, versterken de culturele afstand tussen Limburgers en niet-Limburgers. De Limburgse dialecten lijken zowel op het platteland als in de steden, in verhouding tot dialecten elders in Nederland bijzonder levendig (Soeters en Felling, 1990:282).

De samenhang met het omliggende niet-Nederlandse gebied blijkt ook op het punt van de religie. De reformatie heeft in dit deel van Europa - in tegenstelling tot het noordelijk gedeelte van ons land - niet blijvend voet aan de grond gekregen. Bij de laatste volkstelling van 1971 gaf 93 procent van de Limburgers aan tot de Rooms-Katholieke kerk te behoren. Alleen in Noord-Brabant vindt men een vrijwel gelijk percentage, in de overige provincies was het percentage katholieken beduidend lager (CBS, 1972:43).

\section{Katholicisme}

Het katholieke karakter van bijna alle Limburgers vormde de voedingsbodem voor de ontwikkeling van een sterke katholieke zuil in deze provincie, in samenhang met een in heel Nederland na circa 1880 optredend proces van verzuiling, waarbij katholieken, orthodox-protestanten en sociaal-democraten de onderlinge verschillen steeds meer gingen institutionaliseren (Pennings, 1991:21). Door Duffhues c.s. wordt onder verzuiling verstaan: "het op levensbeschouwelijke basis organiseren van profaan geachte maatschappelijke functies" (Duffhues, Felling en Roes, 1985:20). In Limburg resulteerde dit proces in de maatschappelijke dominantie van bestuurlijk met elkaar verknoopte katholieke organisaties en instellingen op het terrein van (onder andere) het onderwijs en de cultuur, de volkshuisvesting, de gezondheidszorg, de sociaal-economische belangenbehartiging, de vrije tijdsbesteding, de media en de (boven-lokale) politiek.

Vanaf het eind van de jaren zestig heeft zich echter een sterke mate van ontkerkelijking en ontzuiling voorgedaan. Verschillende enquêtes gaven aan het eind van de jaren tachtig aan dat het percentage Limburgers dat zichzelf als katholiek beschouwde gedaald was tot ruim 70 procent (Nissen, 1990:298). Toch bleef het percentage onkerkelijken in Limburg nog relatief laag, in vergelijking met andere provincies (Knippenberg en De Pater, 1988:199).

Een nog sterkere teruggang geven de cijfers over de mate van kerksheid van de Limburgse katholieken te zien. In maart 1988, bijvoorbeeld, lag de participatie in de weekendmissen in het Bisdom Roermond (dat samenvalt met de provincie Limburg) 
op slechts 18 procent van de als katholiek geregistreerden (Nissen, 1990:318). De dalende tendens die aan het eind van de jaren zestig inzette, was twintig jaar later nog. steeds niet tot stilstand gekomen.

Parallel aan het verminderde kerkbezoek is er ook een verandering in de attitudes van gelovigen te bespeuren, die door Andeweg is aangeduid als verminderde religieuze orthodoxie en die juist onder Nederlandse katholieken bijzonder sterk is geweest. (Andeweg, 1982:63; voor Limburg: Wijnen en Koopmanschap, 1981: 14 e.v.). Traditionele opvattingen over geloofskwesties en maatschappelijke vraagstukken veranderden in een zeer snel tempo.

\section{Ontzuiling}

Met het wegvallen van vanzelfsprekende gedrags- en denk-patronen die sterk verbonden waren met richtinggeving door de clerus, kreeg een proces van ontzuiling zijn beslag. De voedingsbodem voor deze ontzuiling is volgens Duffhues c.s. al in de jaren vijftig ontstaan en in de jaren zestig versterkt toen grote delen van de katholieke bevolking gepreoccupeerd raakten "met een streven naar ontvoogding in eigen katholieke kring en naar zelfbeschikking met betrekking tot de relaties met de buitenwereld" (Duffhues, Felling en Roes, 1985:23). Dit emancipatie-streven uitte zich binnen de zuil in onder andere een geleidelijke doelverlegging, declericalisering en heterogenisering van organisaties en bestuurders. Parallel aan deze interne ontwikkelingen was er in toenemende mate sprake van integratie van de katholieke zuil in nationale structuren, hetgeen aanleiding gaf tot relativering van de eigen katholieke identiteit (Duffheus, Felling en Roes, 1985:33 e.v.). In wisselwerking met de culturele en structurele veranderingen van de samenleving, die na de oorlog in een zekere stroomversnelling geraakten, vonden zowel aan de top als aan de basis van de verzuilde instituties processen plaats die resulteerden in ontzuiling (vgl. Pennings, 1991:24 e.v.).

Korsten signaleert een aantal manieren waarop dit ontzuilingsproces in Limburg zichtbaar is geworden (Korsten, 1991). Binnen de katholieke organisaties en instellingen ging de katholieke identiteit een minder belangrijke rol spelen en werd de afstand ten opzichte van de katholieke kerk vergroot. De bestuurlijke verbindingen binnen de zuil verminderden. Daarnaast ontdeed een aantal voorheen katholieke instellingen en organisaties zich geheel van de katholieke grondslag of ging over tot intensieve 'zuiloverschrijdende' samenwerking (bijvoorbeeld in de vakbeweging en de politiek). In dit verband wordt ontzuiling ook wel getypeerd als het vervagen van sub-culturele grenzen (Van der Eijk en Niemöller, 1983). Tenslotte keerden ook veel zich nog katholiek voelende burgers zich af van katholieke organisaties zoals de Katholieke Radio-Omroep en de KVP.

Aan de hand van een analyse van de gevolgen van de ontzuiling in Limburg concludeert Korsten:

"Een deel van het verzuilde gebouw bestaat nog. Dat deel bevat nog een dak; het geeft beschutting. Maar van een ander deel van het gebouw bestaan alleen nog de tekeningen; het is de zuilrest van de statuten; onzichtbaar, liggend in bureauladen." (Korsten, 1991:43)

Duffhues c.s. stellen dat het organisatiepatroon van de katholieke zuil in stand blijft: 
"zolang een elite van bestuurders en professionals het wenselijk. acht, de technisch-organisatorische oplossingen voldoen, zolang de gemeenschappelijke katholieke waarden en belangen nog, effectief behartigd worden en een draagvlak hebben, en zolang er een financiële basis bestaat." (Duffhues, Felling en Roes, 1985:36).

Aan deze voorwaarden lijkt in het begin van de jaren negentig vooral nog in de onderwijs- en zorgsector te zijn voldaan. In de sociaal-economische sector, daarentegen, is het verdwijnen van de meeste katholieke stands- en vakorganisaties een markant ontzuilingsverschijnsel. Op de politieke uitwerking van het ontzuilingsproces in Limburg komen wij in de volgende paragraaf terug.

Ondanks de ontkerkelijking en de (gedeeltelijke) afbraak en uitholling van de katholieke zuil die ook in Limburg manifest is geworden, is er nog altijd sprake van een afwijkend cultuurpatroon in deze provincie.

Een empirische aanwijzing daarvoor vormt een in 1985 uitgevoerde vergelijking van attitudes van Limburgse, Brabantse en Randstedelijke katholieken. Uit dit onderzoek bleek dat de Limburgse respondenten op verschillende onderdelen een duidelijk afwijkende positie innamen ten opzichte van hun niet-Limburgse geloofsgenoten (Felling en Peters, 1988).

Katholieke Limburgers waren conservatiever dan de Brabantse en Hollandse respondenten op het punt van ingrepen in het leven (abortus provocatus en euthanasie) en hadden vaker traditionele opvartingen over onderwerpen als alternatieve samenlevingsvormen en de positie van de vrouw. Voorts was er sprake van een relatief sterke oriëntatie op de eigen lokale gemeenschap en bleken de Limburgse respondenten eerder geneigd zich aan te passen aan de normen die in de eigen buurt heersen. De onderzoekers constateerden daamaast dat de katholieke Limburgers naar voren komen als tamelijk autoritair. Hieronder verstaan zij het aanhangen van conventionele normen en waarden en veroordeling van overtreders daarvan, een onkritische identificatie met autoriteiten en de neiging om in rigide categorieën te denken. Tenslotte kwam uit het onderzoek naar voren dat relatief veel Limburgse katholieken gekenmerkt werden door anomie, dat wil zeggen een toestand van sociale desoriëntatie en onzekerheid.

Toch lijkt het erop dat er in cultureel opzicht sprake is geweest van een nationaliseringsproces, waarvan vooral de jongere generatie Limburgers de drager vormde. De cultuurpatronen van Limburgse, Brabantse en Randstedelijke jonge respondenten lagen minder ver uit elkaar dan die van de oudere leeftijdsgroepen (Soeters en Felling, 1990: 292) ${ }^{2}$. Het draagvlak voor katholieke organisaties en instellingen, dat door Duffhues c.s. als een wezenlijke voorwaarde voor hun voortbestaan wordt gezien, lijkt daarmee verder af te brokkelen.

2 Deze analyse is gebaseend op dezelfde onderzoeksgegevens als Felling en Peters, 1988. 


\subsection{Electorale verhoudingen bij landelijke en provinciale verkiezingen ${ }^{3}$}

Aan de hand van de verkiezingsuitslagen van de partij met de grootste electorale aanhang in Limburg, de KVP en vanaf 1977 het CDA, kan een driedeling in de tijd worden aangebracht. In de eerste periode, van 1946 tot 1963, behaalde de KVP in deze provincie bij landelijke en provinciale verkiezingen steeds rond de tachtig procent van het aantal uitgebrachte stemmen. De tweede periode, van 1963 tot 1972, staat in het teken van een snelle electorale neergang van de KVP. In de derde periode, vanaf 1972 , is deze neergang tot stilstand gekomen en beweegt de verkiezingsuitslag van de KVP, c.q. haar opvolger het $\mathrm{CDA}$, zich tussen 40 en 50 procent.

\section{Periode 1946-1963}

In de eerste naoorlogse decennia werden de politieke verhoudingen in Nederland beheerst door de sterk verzuilde maatschappelijke verhoudingen (Daalder 1974; Lijphart 1968 en 1979; Righart, 1986). De KVP verkreeg, als politieke arm van de katholieke zuil, tot in de jaren zestig bij boven-lokale verkiezingen een zeer massale steun van het Limburgse electoraat. Bij nationale en provinciale verkiezingen in de periode 1946-1963, haalde deze partij scores van rond de 80 procent (zie tabel 2.2). In de overige tien provincies bij elkaar opgeteld bleef de KVP in diezelfde periode op een gemiddelde van ongeveer 30 procent van de stemmen steken (Spoormans, Welten en Dittrich, 1990:340).

Voor de overige partijen waren er in de periode van verzuiling in Limburg weinig stemmen te behalen. De enige partij die in de schaduw van de KVP een wat grotere aanhang kon opbouwen was de Partij van de Arbeid. Het stemmenpercentage van deze partij bewoog zich tussen bijna 7 en ruim 17 procent. Het gemiddelde van de PvdA buiten Limburg lag in deze periode rond de 30 procent. Incidentele successen had daarnaast de katholieke dissidentenlijst 'groep-Welter', later Katholieke Nationale Partij, die met name kritiek had op de 'rooms-rode' coalitie van de KVP met de PvdA (Luykx, 1987:59) 4 .

Voor een verklaring van het grote electorale succes van de KVP in de eerste na-oorlogse decennia, wordt veelal gewezen op de rol van de kerkleiding bij het bewaren van de katholieke eenheid en het bestrijden van gevoelde bedreigingen uit niet-katholieke hoek, ook op politiek gebied (voor de Limburgse situatie: Reerink, 1989; Spoormans, Welten en Dittrich, 1990). Een laatste openlijke manifestatie daarvan vormde het bisschoppelijk mandement van 1954, waarin katholieken werden opgeroepen om trouw te blijven aan de eigen katholieke organisaties. Het lidmaatschap van de PvdA werd voor katholieken 'onverantwoord' geacht. Door de hoge organisatiegraad van de katholieke zuil waren er veel aangrijpingspunten voor de

3 Deze paragraaf is deels gebaseerd op een eerdere publicatie; Kuiper en Dittrich, 1991.

4 Bij de Tweede Kamerverkiezingen van 1948 behaalde deze partij 3 procent van de Limburgse stemmen en in 1952 ruim 6 procent, bij de verkiezingen voor Provinciale Staten in 1950 bijna 2 procent. 
Tabel 2.2. Uitslagen van Tweede Kamerverkiezingen en verkiezingen voor Provinciale Staten in Limburg, 1946-1963 (in percentages van het totaal aantal geldig uitgebrachte stemmen).

\begin{tabular}{lrrllll}
\hline & KVP & PvdA & VVD & CPN & Overige & Totaal \\
\hline TK1946 & 79,6 & 12,5 & 0,6 & 5,6 & 1,7 & 100 \\
PS1946 & 82,0 & 9,1 & - & 5,9 & 3,0 & 100 \\
TK1948 & 81,5 & 8,6 & 0,8 & 3,7 & 5,4 & 100 \\
PS1950 & 83,7 & 6,8 & - & 2,7 & 6,8 & 100 \\
TK1952 & 75,4 & 12,8 & 0,9 & 2,3 & 8,6 & 100 \\
PS1954 & 82,0 & 12,4 & - & 1,3 & 4,3 & 100 \\
TK1956 & 78,6 & 17,5 & 0,9 & 1,0 & 2,0 & 100 \\
PS1958 & 84,3 & 12,0 & - & 1,2 & 2,5 & 100 \\
TK1959 & 79,5 & 15,0 & 2,5 & 1,0 & 2,0 & 100 \\
PS1962 & 82,0 & 12,9 & 1,6 & 1,3 & 2,2 & 100 \\
TK1963 & 77,5 & 12,9 & 2,3 & 1,7 & 5,6 & 100 \\
\hline
\end{tabular}

TK = Verkiezingen voor de Tweede Kamer, PS = Verkiezingen voor Provinciale Staten.

Bron: CBS, Statistieken der verkiezingen

geestelijkheid om door middel van (positieve dan wel negatieve) sanctionering de volgzaamheid van katholieken te bevorderen (Bakvis, 1978).

Gelet op de werking van informele sociale controle en de neiging tot conformeren aan de opvattingen van referentiegroepen ${ }^{5}$ is het bovendien verklaarbaar dat individuen uit zichzelf niet gemakkelijk tot afwijkende politieke stellingnames kwamen. Wanneer familie, buren, dorps- en verenigingsgenoten allemaal deel uitmaken van de katholieke kerk en de daaraan gelieerde organisaties, dan is de stap om zich buiten dat verband te begeven tamelijk moeilijk (vgl. Houska, 1985:11).

Behalve vanuit de (veelal onbewuste) werking van sociale controle, kan de massale keuze voor de KVP tenslotte worden begrepen vanuit het welbegrepen eigenbelang van veel Limburgse kiezers. De KVP lijkt door haar plaats te midden van de maatschappelijk dominante katholieke instellingen en organisaties goed in staat te zijn geweest om de belangen van kiezers van alle rangen en standen op effektieve wijze te behartigen. Of dat ook daadwerkelijk gebeurde is wellicht minder van belang dan het feit dat deze partij in ieder geval de suggestie kon wekken dat men daartoe beter uitgerust was dan de concurrerende partijen.

\section{Periode 1963-1972}

In de betrekkelijk korte periode van 1963 tot 1972 is het Limburgse politieke landschap ingrijpend gewijzigd, zoals in tabel 2.3 is te zien.

Op het eind van deze periode was de KVP-aanhang vrijwel gehalveerd, van rond de 80 naar ruim 40 procent. Aan deze snelle electorale achteruitgang, lagen met name de eerder besproken maatschappelijke processen als ontkerkelijking (vooral in de vorm

5 Zie over dit fenomeen bijvoorbeeld Keers, Wilke en Kampschuur, 1981:190. 
Tabel 2.3. Uitslagen van Tweede Kamerverkiezingen en verkiezingen voor Provinciale Staten in Limburg, 1963-1972 (in percentages van het totaal aantal geldig uitgebrachte stemmen).

\begin{tabular}{|c|c|c|c|c|c|c|c|}
\hline & KVP & PvdA & VVD & D66 & Klein Links* & Overige & Totaal \\
\hline TK 1963 & 77,5 & 12,9 & 2,3 & - & 1,7 & 5,6 & 100 \\
\hline PS1966 & 73,1 & 11,1 & 3,4 & - & 3,3 & 9,1 & 100 \\
\hline TK 1967 & 63.7 & 11,8 & 5,1 & 3,1 & 3,5 & 12,8 & 100 \\
\hline PS 1970 & 64,3 & 10,2 & 6,2 & 6,8 & 10,2 & 2,3 & 100 \\
\hline TK 1971 & 54,1 & 14,5 & 5,2 & 7,3 & 5,9 & 13,0 & 100 \\
\hline TK 1972 & 43,9 & 20,2 & 12,3 & 4,0 & 8,7 & 10,9 & 100 \\
\hline
\end{tabular}

* Klein Links: PPR, PSP en CPN; TK = Verkiezingen voor de Tweede Kamer; PS = Verkiezingen voor Provinciale Staten.

Bron: CBS. Statistieken der verkiezingen

van een toenemend aantal randkerkelijken), verminderde religieuze orthodoxie en ontzuiling ten grondslag (Andeweg, 1982; Van der Eijk en Niemöller, 1983; Dittrich, Tops en Welten, 1986; Passchier, 1987; voor Limburg: Spoormans, Welten en Dittrich, 1990; Korsten, 1991; Kuiper en Dittrich, 1991).

Niet alleen het aantal katholieken nam af, ook de vanzelfsprekendheid voor katholieken om op een katholieke partij te stemmen was verdwenen. ${ }^{6}$ De tot dan toe effectieve mechanismen van sociale controle en belangenbehartiging door de katholieke instanties, waren niet langer in staat om het eenmaal in de Limburgse samenleving op gang gekomen proces van ontzuiling op het politieke vlak te keren.

Daarbij kwam dat er zich enkele nieuwe concurrenten voor de KVP in deze periode aandienden, naast de van oudsher in Limburg nog niet zeer populaire sociaal-democratische en liberale partijen. Enkele nieuwe partijen die het door de tanende KVP achtergelaten vacuüm op de kiezersmarkt aanvankelijk wisten op te vullen waren de Boerenpartij (in 1967), Democraten '66 (vanaf 1967), de Politieke Partij Radikalen (vanaf 1970) en Democratisch-Socialisten '70 (vanaf 1971). Deze partijen profiteerden aanvankelijk het meest van de dalende populariteit van de katholieke partij. Kennelijk bestond er bij veel kiezers nog een zekere barrière om de overstap naar één van de andere traditioneel aan een zuil verbonden partijen te maken?

6 Anders dan Dittrich, Tops, en Welten suggereren houdt dit proces van politieke deconfessionalisering niet uitsluitend in dat: 'religieuze overtuiging en politieke voorkeur worden losgekoppeld' (Dittrich, Tops en Welten, 1986:297). De religieuze overtuiging kan juist ook de motivatie opleveren voor een loskoppeling van de traditionele katholieke partij en dus een andere politieke voorkeur. Deconfessionalisering omvat beide vormen van loskoppeling.

7 Die barrière kan zich overigens ook sinds de afschaffing van de opkomstplicht in 1970 geuit hebben in het thuisblijven van voormalige KVP-stemmers. In dit verband wijzen wij op het feit dat de opkomst bij boven-lokale verkiezingen in Limburg sinds 1970 beduidend onder het landelijk gemiddelde is gebleven (CBS, Statistieken der Verkiezingen), (zie ook tabel 3.4 in het volgende hoofdstuk). 
De PvdA maakte pas aan het einde van deze periode - bij de Tweede Kamerverkiezingen in 1971 en vooral in 1972 - een duidelijke sprong vooruit in Limburg naar ruim 20 procent in dat laatste jaar. Ook de VVD boekte een forse winst in 1972, toen de aanhang van deze partij groeide van ruim 5 naar ruim 12 procent. De overige partijen verkregen in dat jaar bijna een kwart van de Limburgse kiezers achter zich.

\section{Periode 1972-1991}

De daling van de KVP-aanhang kwam even abrupt tot stilstand als zij begonnen was. In de periode na 1972 was er sprake van een stabilisatie en uiteindelijk van enige winst voor het CDA, de in 1980 uit een fusie van de KVP met de ARP en CHU voortgekomen christen-democratische partij. (Bij de Tweede Kamerverkiezingen van 1977 deden de drie confessionele partijen al eerder onder de naam CDA met een gezamenlijke lijst aan landelijke verkiezingen mee.) De resultaten van deze partij lagen tot aan de Statenverkiezingen van 1991 steeds rond de 45 procent (zie tabel 2.4).

Deze stabiliteit is opmerkelijk te noemen gezien het feit dat de processen die eerder tot de scherpe daling van het aantal confessioneel stemmende kiezers leidden, ook na 1972 bleven doorwerken. In de jaren zeventig en tachtig bleef de ontkerkelijking gestaag toenemen. Ook door demografische processen was er sprake van een stijgend percentage buitenkerkelijken en randkerkelijken binnen het electoraat (Van der Eijk en Niemöller, 1983). Het CDA slaagde er echter in om een groter deel van haar (op zich slinkende) natuurlijke 'marktsegment' (bestaande uit kerkelijke en randkerkelijke kiezers) te bereiken.

Hoe dit relatieve succes van het CDA tot stand kwam is onduidelijk. Bakvis heeft erop gewezen dat de verkiezingsnederlagen van de KVP in de jaren zestig mede in verband moeten worden gebracht met een aantal ontwikkelingen binnen de confessionele partij zelf, in het bijzonder het optreden van het partijkader (Bakvis, 1978:237 e.v.). ${ }^{8}$ Hij wijst op het ontbreken van een poging van de kant van het partijkader om door veranderingen binnen de partij nieuwe wegen te zoeken, waarlangs de negatieve spiraal doorbroken zou kunnen worden en de partij weer aan wervingskracht zou kunnen gaan winnen. Houska verklaart de neergang van de confessionele partij eveneens mede vanuit de falende strategie van de partij-elite in het zicht van de ontzuiling (Houska, 1985).

Deze factor vormt tevens een aanknopingspunt om het latere succes van de confessionelen te verklaren. Uiteindelijk werden die inteme veranderingen namelijk wel doorgevoerd, met name in het kader van de omvorming van de KVP tot het CDA. Het KVP-label dat niet alleen een verliezers-image had verkregen, maar voor veel kiezers cok het symbool vormde van een zuil waaraan men zich trachtte te ontworstelen, kon op die manier geruisloos verdwijnen. De nieuwe partij richtte zich niet langer geheel en uitsluitend op de organisaties van de overblijfsels van de katholieke en protestantse verzuiling en de kiezers die daarin geïnvolveerd waren. De partij-elite koos voor wat Houska noemt een 'cath-more'-strategie, waarbij werd geappelleerd aan een bredere

8 Het is overigens opvallend dat de andere aangehaalde auteurs aan deze achtergronden van de neergang van de KVP geen aandacht besteden. 
Tabel 2.4. Uitslagen van Tweede Kamerverkiezingen en verkiezingen voor Provinciale Staten in Limburg, 1972-1989 (in percentage van het totaal aantal geldig uitgebrachte stemmen).

\begin{tabular}{|c|c|c|c|c|c|c|c|}
\hline & KVP/CDA & PvdA & VVD & D66 & Klein Links* & Overige: & Totaal \\
\hline TK 1972 & 43,9 & 20,2 & 12,3 & 4,0 & 8,7 & 10,9 & 100 \\
\hline PS1974 & 49.7 & 18,6 & 15,2 & 0,7 & 10,6 & 5,2 & 100 \\
\hline TK 1977 & 44,6 & 30,1 & 14,7 & 3,3 & 3,7 & 3,6 & 100 \\
\hline PS 1978 & 51,4 & 29,2 & 12,1 & 2,9 & 4,3 & 0,1 & 100 \\
\hline TK1981 & 43,2 & 25,4 & 12,6 & 11,2 & 4,6 & 3,0 & 100 \\
\hline PS 1982 & 51,4 & 16,3 & 17,1 & 6,9 & 6,5 & 1,8 & 100 \\
\hline TK 1982 & 42,9 & 26,2 & 18.6 & 4,7 & 5,1 & 2,5 & 100 \\
\hline PS1987 & 43,0 & 32,5 & 9,7 & 4,2 & 3.7 & 6,8 & 100 \\
\hline TK 1986 & 46,0 & 33,9 & 11.4 & 4,4 & 2,2 & 2,2 & 100 \\
\hline TK 1989 & 46,9 & 33,4 & 9.1 & 5,5 & 3,0 & 2,1 & 100 \\
\hline PS1991 & 47,4 & 18,9 & 10,3 & 9,9 & 4,2 & 9,3 & 100 \\
\hline
\end{tabular}

* Klein Links: PPR, PSP, CPN en EVP; in 1989 Groen Links; TK = Verkiezingen voor de Tweede Kamer, PS = Verkiezingen voor Provinciale Staten.

Bron: CBS, Statistieken der verkiezingen

doelgroep dan voorheen en niet werd gestreefd naar restauratie en herzuiling (Houska, 1985:128, 138).

De introduktie van het CDA viel bovendien op een voor die partij gelukkige wijze samen met een zekere malaise bij de nieuwe partijen, die aan het eind van de jaren zeventig veel van hun aanvankelijke aantrekkingskracht hadden verloren. Bij de PvdA, de VVD en D669 was er in de periode 1972-1991 sprake van sterk wisselende verkiezingsuitslagen. De landelijke trends voor deze partijen waren steeds ook in de Limburgse uitslagen zichtbaar.

De PvdA kreeg, zoals vermeld, aan het begin van de jaren zeventig rond de dertig procent van het Limburgse electoraat achter zich. Na een lichte terugval bij de Kamerverkiezingen van 1981 en een zeer scherpe daling bij de Statenverkiezingen één jaar later, groeide de aanhang weer tot bijna 34 procent in 1986. Bij de laatste in deze periode gehouden verkiezingen, die voor Provinciale Staten in 1991, leed de PvdA in Limburg en elders een zeer fors verlies. In dat jaar behaalde deze partij weer minder dan 20 procent. De PvdA-scores bij boven-lokale verkiezingen in Limburg lagen vanaf 1977 steeds dichtbij de landelijke gemiddelden voor deze partij.

De uitslagen van de VVD en D66 in Limburg bleven in de gehele periode daarentegen duidelijk onder de landelijk gemiddelden van die parijen. In het begin van de jaren tachtig verkreeg de VVD een stemmenpercentage van bijna 20, aan het einde van de hier behandelde periode viel deze partij terug tot rond de tien procent van het Limburgse electoraat. D66 kende een dieptepunt bij de Statenverkiezingen van 1974 $(0,7$ procent) en hoogtepunten bij de Tweede Kamerverkiezingen van 1981 (11,2

9 Tot 1985 werd deze partij afgekort als D'66, in deze studie wordt de huidige afkorting D66 aangehouden. 
procent) en de verkiezingen voor Provinciale Staten in 1991 (9,9 procent). Bij de overige verkiezingen in de jaren tachtig schommelde de Limburgse aanhang van deze partij rond de 5 procent. De kleinere linkse partijen bleven daar in Limburg nog onder.

\section{Samenvatting van de electorale ontwikkelingen}

In de hele naoorlogse periode is de katholieke, later christen-democratische partij bij boven-lokale verkiezingen in Limburg steeds de partij met de grootste aanhang geweest. Tot in de tweede helft van de jaren zestig stemde meer dan driekwart van het Limburgse electoraat steevast op deze partij. Aan het eind van de jaren zestig was er sprake van een sterke vermindering van de KVP-aanhang. Aanvankelijk profiteerden vooral enkele nieuwe partijen als de Boerenpartij, D66, DS'70 en de PPR van die neergang. Vanaf de jaren zeventig groeide de Limburgse aanhang van de VVD en vooral die van de PvdA. Terwijl het stemmenpercentage op de KVP en het latere CDA in de laatste periode tamelijk stabiel bleef, ondergingen de overige partijen afwisselend sterke groei en sterke daling, in overeenstemming met de landelijke trends. Hoewel de VVD en D66 incidentele successen behaalden, bleef de aanhang van deze partijen in Limburg onder het landelijk gemiddelde. 


\section{Hoofdstuk 3}

\section{Electorale ontwikkelingen in de Limburgse lokale politiek}

\subsection{Inleiding}

Bij de in dit hoofdstuk centraal staande beschrijving van electorale ontwikkelingen in de naoorlogse Limburgse lokale politiek, wordt een indeling gehanteerd in twee perioden. De eerste naoorlogse decennia kunnen (in navolging van Dittrich, 1978) worden aangeduid als de 'communalistische' periode. Daarmee bedoelen wij dat in deze periode in de meeste Limburgse gemeenten geen lijsten van landelijke partijen deelnamen aan de plaatselijke politiek. Lokale politiek was het vrijwel exclusieve domein van lokale lijsten ${ }^{1}$.

Het verkiezingsjaar 1978 markeerde het begin van de tweede periode, die in het teken stond van de opkomst van landelijke lijsten, ofwel de 'nationalisering' van de lokale politieke verhoudingen, alsmede van grootschalige gemeentelijke herindeling in Limburg. Aan een beschrijving van de electorale ontwikkelingen in deze periode gaat een aparte beschouwing vooraf over de mogelijke oorzaken van de prominente plaats van lokale lijsten in de Limburgse lokale politiek (paragraaf 3.2).

De in dit hoofdstuk beschreven ontwikkelingen betreffen naast de electorale aanhang en spreiding van verschillende typen lijsten ook het aantal deelnemende lijsten per gemeente, het opkomstpercentage en het percentage voorkeurstemmen. Bij een aantal van deze onderwerpen wordt (voorzover gegevens voorhanden zijn) een vergelijking gemaakt tussen Limburgse en landelijke gemiddelden, en in enkele gevallen ook provinciale gemiddelden - om zicht te krijgen op bijzondere kenmerken van de Limburgse lokale politiek.

1 Deze lijsten worden ook wel 'communale' lijsten genoemd (Tops, 1990). In deze studie worden de termen lokale lijsten en plaatselijke politieke groeperingen gehanteerd, om de betreffende lijsten aan te duiden. 


\section{Definitie van lokale lijst}

In dit hoofdstuk wordt gebruik gemaakt van de verkiezingsstatistieken die het Centraal Bureau voor de Statistiek (CBS) over de resultaten van de gemeenteraadsverkiezingen opstelt.

Het CBS onderscheidt 'landelijk bekende politieke groeperingen' van 'plaatselijke groeperingen, welke slechts lokale doeleinden nastreven'. Binnen deze laatste categorie worden vervolgens een aantal verschillende subcategorieën onderscheiden, waarbij een verschil kan worden gemaakt tussen een aantal grensgevallen (gemengd lokaal/landelijke lijsten) en een nadere onderverdeling van uitsluitend lokale lijsten. De grensgevallen worden door het CBS bij de categorie landelijke lijsten ondergebracht. Dit zijn de volgende typen lijsten:

a. Gemengd Gecombineerde lijst; Indien twee of meer van de algemeen bekende politieke groeperingen gezamenlijk zijn opgetreden en één of meer van deze groeperingen een niet-protestants-christelijke groepering is, eventueel gecombineerd met ćén of meer lokale groepen.

b. Progressief Akkoord (PAK); Indien een gecombineerde lijst is uitgekomen van twee of meer van de algemeen bekende groeperingen CPN, D66, PPR, PSP en PvdA.

c. Protestants-Christelijke Gecombineerde lijst (PCG); Indien twee of meer van de protestants-christelijke groeperingen (GPV, RPF of SGP; voorheen ook ARP of $\mathrm{CHU}$ ) gezamenlijk zijn opgetreden, eventueel in combinatie met andere protestants-christelijke groepen.

In Limburg kwamen GG- en PCG-lijsten vrijwel niet voor. PAK-lijsten deden wel in veel gemeenten aan gemeenteraadsverkiezingen mee. Dit type lijst kwam zowel onder de naam Progressief Akkoord als onder een op de betreffende gemeente betrokken naam voor, zoals Progessief Swalmen, Helden Links of de lijst Zalm in Maastricht. In het laatste geval is de indeling bij de categorie landelijke lijsten discutabel. Het CBS volgt op dit punt de door de gemeenten opgegeven indeling.

In de statistieken van de gemeenteraadsverkiezingen van 1990 heeft het CBS voor dit type lijst een aparte rubriek geopend; Progressieve Groepering (PG). De definitie van deze groepering, die overigens evenals de PAK-lijsten bij de landelijke lijsten wordt geteld, omvat de volgende twee typen lijsten:

- een gecombineerde lijst waarbij minimaal één van de groeperingen een algemeen bekende linkse groepering is;

- een anderszins duidelijk linkse combinatie c.q. groepering.

$\mathrm{Bij}$ de verwerking van de lijsttrekkersenquêtes wordt van de indeling bij landelijke lijsten van deze lokale progressieve groeperingen op grond van nadere informatie over de aard van de lijst, in een enkel geval afgeweken. Overal waar in deze studie gebruik wordt gemaakt van andere bronnen dan de lijsttrekkersenquêtes, zoals gegevens van het CBS, is echter de bovenvermelde scheidslijn tussen lokale en landelijke lijsten gehanteerd.

In dit hoofdstuk is het van belang om een onderscheid aan te brengen tussen PAK-lijsten met en zonder deelname van de PvdA. Op die manier kan een indruk gegeven worden van de spreiding van de drie grote landelijke partijen bij Limburgse 
gemeenteraadsverkiezingen. Daartoe zijn de PAK-lijsten steeds bij de PvdA geteld, tenzij in de betreffende gemeente een aparte PvdA-lijst naast de PAK-lijst aan de verkiezingen deelnam.

\section{Nadere indeling lokale lijsten}

De overblijvende lokale lijsten of plaatselijke politieke groeperingen probeerde het CBS tot en met 1986 "in enkele rubrieken onder te brengen, lettend op de aard en strekking van deze groepen" (CBS, 1984:17). Het betrof de volgende drie rubrieken:

a. Protestants-Christelijke lijst; indien een protestants-christelijke groep een lijst heeft ingediend en niet is gebleken dat deze geldt als de officiële respectievelijk hoofdlijst van één van de bekende christelijke groeperingen.

b. Rooms-Katholieke lijst; indien een rooms-katholieke groep (middenstanders, boeren, arbeiders, buurtschappen) een lijst heeft ingedien en niet is gebleken dat deze geldt als de officile lijst, respectievelijk hoofdlijst, van één van de bekende christelijke groeperingen.

c. Onafhankelijken; indien uitsluitend de naam van de lijstaanvoerder (lijsttrekker) is vermeld en een specificatie naar kerkelijke of politieke gezindte niet mogelijk bleek, of indien de lijst wordt aangeduid als een plaatselijke kiesvereniging, gemeentebelang respectievelijk algemeen belang (zonder aanduiding van kerkelijke gezindte of onder uitdrukkelijke vermelding van bijvoorbeeld neutrale middenstanders, boeren enz.)

De categorie 'onafhankelijken' werd tot en met 1978 ondergebracht in de rubriek 'overige'. In deze rubriek werden echter ook lijsten ondergebracht van landelijk bekende groeperingen die uitsluitend op een bepaalde regio gericht waren (zoals de Friese Nationale Partij (FNP)) en soms ook zuiver landelijke groeperingen die slechts in een enkele gemeente aan verkiezingen deelnamen (zoals DS'70 in 1970). Vanaf 1982 brengt het CBS een scheiding aan tussen de rubrieken 'onafhankelijk' (uitsluitend lokale lijsten) en 'overige' (uitsluitend landelijk bekende lijsten, waarbij de regionaal opererende FNP voortaan als 'onafhankelijk' telt). In dit hoofdstuk wordt de categorie 'overige' dan ook tot en met 1978 bij de lokale lijsten gerekend en in de tabellen die betrekking hebben op latere verkiezingsjaren als landelijk gerubriceerd.

Het onderscheid tussen protestants-christelijke (PC) en rooms-katholieke (RK) lijsten enerzijds en onafhankelijke lijsten anderzijds, blijkt in de praktijk moeilijk hanteerbaar. Het CBS benadrukt in haar publicaties steeds het enigszins arbitraire karakter ervan. Beide categorieën worden in dit hoofdstuk dan ook gezamenlijk onder de noemer 'lokale lijsten' gevat. Een nadere typologie van lokale lijsten komt in het volgende hoofdstuk aan de orde.

In de statistieken van de verkiezingen van 1990 werden de protestants-christelijke en rooms-katholieke lokale lijsten samen met wat voorheen als (landelijke) PCG-lijsten werd aangeduid, samengevoegd onder de noemer Confessionele Groepering. De definitie van deze categorie luidt:

- een gecombineerde lijst waarbij minimaal één van de groeperingen een algemeen bekende christelijke groepering is; 
- een protestants-christelijke dan wel een rooms-katholieke groep die een lijst heeft ingediend die niet geldt als officiële lijst van één van de bekende christelijke groeperingen.

Ook de lijsten die door het CBS in deze categorie zijn ingedeeld worden in deze studie als lokale lijst beschouwd.

Het onderscheid tussen KVP-lijsten en RK-lijsten is in de periode tot en met 1978 door het CBS niet steeds consequent aangebracht. Zo komt het voor dat bij de weergave van de stemverdeling in een aantal Limburgse gemeenten de op RK-lijsten uitgebrachte stemmen in de betreffende kolom zijn ondergebracht, terwijl bij het overzicht van de raadssamenstelling de zetels als toegevallen aan de KVP worden beschouwd. Ook het omgekeerde komt voor. Bovendien zijn in een aantal gemeenten stemmen die op verschillende lijsten zijn uitgebracht in de tabel bij elkaar geteld en gerangschikt onder de KVP in plaats van onder de categorie RK. In al deze gevallen zijn de statistieken gecorrigeerd met dien verstande dat zowel de stemmen als de zetels toegerekend zijn aan lokale lijsten en niet aan de (landelijke) KVP-lijst. Voor de verkiezingsjaren 1970, 1974 en 1978 is ter aanvullende controle gebruik gemaakt van de vermelding van lijstnamen op de ANP-uitslagen.

\subsection{De communalististische periode}

\section{Zetelverdeling}

Om een eerste indruk te verkrijgen van de politieke verhoudingen in Limburg bij gemeenteraadsverkiezingen, is in tabel 3.1. de verdeling van raadszetels over de diverse politieke groeperingen in de communalistische periode weergegeven, met in de meest rechtse kolom het omslagjaar 1978.

Het door de KVP behaalde zeteltal vertoonde na 1946 een sterke daling. In 1958 was er sprake van een lichte stijging die echter van incidentele aard bleek te zijn. Pas in 1978 nam het zeteltal van het CDA en ook van de PvdA en de VVD aanmerkelijk toe. In eerdere verkiezingsjaren werd een grote meerderheid van tussen de 77 en 87 procent van alle Limburgse raadszetels ingenomen door personen die via een lokale lijst werden verkozen. In 1978 daalde dat percentage tot 70 . Deze electorale verhoudingen hangen sterk samen met het beperkte aantal door de diverse landelijke partijen uitgebrachte lijsten in de betreffende periode van de verschillende typen lijsten.

\section{Spreiding van lijsten}

De communalistische periode werd, zoals vermeld, gekenmerkt door de beperkte deelname van landelijke lijsten aan de Limburgse lokale politiek. De omvang van deze deelname is zichtbaar gemaakt in tabel 3.2, waarin een overzicht is gegeven van de spreidingsgraad van de drie grootste politieke partijen. Deze spreidingsgraad is berekend door het aantal gemeenten waarin lijsten van de betreffende groepering werden ingediend uit te drukken als percentage van het totaal aantal Limburgse gemeenten. Tevens is het percentage gemeenten waarin geen enkele landelijke lijst aan de verkiezingen meedeed in deze tabel opgenomen. 
Tabel 3.1. Door politieke groeperingen behaalde raadszetels bij gerneenteraadsverkiezingen in de gezamenlijke Limburgse gemeenten, 1946-1978.

\begin{tabular}{lrrrrrrrrr}
\hline & 1946 & 1949 & 1953 & 1958 & 1962 & 1966 & 1970 & 1974 & 1978 \\
\hline KVP/CDA* & $17,9 \%$ & $14,8 \%$ & $10,2 \%$ & $11,3 \%$ & $10,8 \%$ & $9,8 \%$ & $7,9 \%$ & $6,4 \%$ & $15,9 \%$ \\
& $(200)$ & $(168)$ & $(118)$ & $(138)$ & $(136)$ & $(131)$ & $(103)$ & $(84)$ & $(212)$ \\
PvdA** & $2,4 \%$ & $2,1 \%$ & $3,4 \%$ & $3,1 \%$ & $2,3 \%$ & $2,0 \%$ & $1,6 \%$ & $4,2 \%$ & $7,6 \%$ \\
& $(27)$ & $(24)$ & $(40)$ & $(38)$ & $(29)$ & $(27)$ & $(20)$ & $(56)$ & $(102)$ \\
VVD & - & - & - & - & - & $0,0 \%$ & $1,1 \%$ & $2,9 \%$ & $4,1 \%$ \\
& - & - & - & - & - & $(3)$ & $(14)$ & $(38)$ & $(55)$ \\
Overige & $2,2 \%$ & $0,8 \%$ & $1,0 \%$ & $1,2 \%$ & $0,4 \%$ & $6,5 \%$ & $2,1 \%$ & $1,9 \%$ & $1,6 \%$ \\
landelijk & $(24)$ & $(9)$ & $(10)$ & $(14)$ & $(5)$ & $(87)$ & $(27)$ & $(25)$ & $(22)$ \\
& & & & & & & & & \\
Totaal landel. & $22,5 \%$ & $17,7 \%$ & $14,6 \%$ & $15,6 \%$ & $13,5 \%$ & $18,3 \%$ & $12,7 \%$ & $15,4 \%$ & $29,2 \%$ \\
lijsten & $(251)$ & $(201)$ & $(168)$ & $(190)$ & $(170)$ & $(248)$ & $(164)$ & $(203)$ & $(391)$ \\
& & & & & & & & & \\
Lokale lijsten & $77,5 \%$ & $82,3 \%$ & $85,4 \%$ & $84,4 \%$ & $86,7 \%$ & $81,7 \%$ & $87,3 \%$ & $84,6 \%$ & $70,4 \%$ \\
& $(864)$ & $(932)$ & $(977)$ & $(995)$ & $(1071)$ & $(1053)$ & $(1126)$ & $(1119)$ & $(947)$ \\
Totaal & $100 \%$ & $100 \%$ & $100 \%$ & $100 \%$ & $100 \%$ & $100 \%$ & $100 \%$ & $100 \%$ & $100 \%$ \\
aantal zetels & $(1115)$ & $(1133)$ & $(1145)$ & $(1222)$ & $(1261)$ & $(1332)$ & $(1290)$ & $(1322)$ & $(1338)$ \\
\hline
\end{tabular}

* In 1970 inclusief Combinatie Christelijke Partijen (CCP); ** Inclusief PAK in gemeenten waar de PvdA niet met een eigen lijst deelnam.

Bron: CBS, Statistieken der verkiezingen

Tabel 3.2. Limburgse gemeenten naar deelname van enkele landelijke lijsten en van lokale lijsten aan gemeenteraadsverkiezingen, 1946-1978.

\begin{tabular}{|c|c|c|c|c|c|c|c|c|c|}
\hline Gemeenten met: & 1946 & 1949 & 1953 & 1958 & 1962 & 1966 & 1970 & 1974 & 1978 \\
\hline KVP/CDA-lijst* & $14 \%$ & $8 \%$ & $7 \%$ & $9 \%$ & $9 \%$ & $9 \%$ & $6 \%$ & $6 \%$ & $15 \%$ \\
\hline PvdA-lijst*** & $18 \%$ & $16 \%$ & $18 \%$ & $21 \%$ & $16 \%$ & $16 \%$ & $16 \%$ & $21 \%$ & $29 \%$ \\
\hline VVD-lijst & - & - & - & - & $2 \%$ & $6 \%$ & $6 \%$ & $19 \%$ & $33 \%$ \\
\hline Lokale lijst(en) & $96 \%$ & $99 \%$ & $95 \%$ & $88 \%$ & $95 \%$ & $97 \%$ & $100 \%$ & $100 \%$ & $99 \%$ \\
\hline \multicolumn{10}{|c|}{ Gemeenten zonder } \\
\hline landelijke lijst & $75 \%$ & $81 \%$ & $80 \%$ & $78 \%$ & $84 \%$ & $78 \%$ & $83 \%$ & $65 \%$ & $59 \%$ \\
\hline $\begin{array}{l}\text { Totaal aantal } \\
\text { gemeenten }\end{array}$ & (111) & $(111)$ & $(111)$ & $(110)$ & $(110)$ & $(110)$ & $(104)$ & $(104)$ & (104) \\
\hline
\end{tabular}

(Leesvoorbeeld: In 1946 werd in $14 \%$ van de Limburgse gemeenten een KVP-lijst uitgebracht. In datzelfde jaar werd in $75 \%$ van de gemeenten geen enkele landelijke lijst uitgebracht.)

* In 1970 inclusief Combinatie Christelijke Partijen (CCP); ** Inclusief PAK in gemeenten waar de PvdA niet met een eigen lijst deelnam.

Bron: CBS, Statistieken der verkiezingen, voor 1970-1978 gecorrigeerd aan de hand van gegevens ANP 
Na 1970 daalde het aantal gemeenten waarin uitsluitend lokale lijsten aan raadsverkiezingen deelnamen. Bij de gemeenteraadsverkiezingen van 1970 waren er nog 86 (van de 104) Limburgse gemeenten waarin geen enkele landelijke partijen op het stembiljet voorkwam. Twee verkiezingen later deed die situatie zich nog maar in 61 gemeenten voor.

De deelname van de KVP (vanaf 1974 CDA) bleef in deze periode in hoofdzaak beperkt tot de steden. In 1970 en 1974 bijvoorbeeld, werden er uitsluitend confessionele landelijke lijsten ingediend in de vier grootste gemeenten van de provincie, Maastricht, Heerlen, Venlo en Kerkrade, alsmede in de middelgrote gemeenten Brunssum en Geleen.

\section{Aantal deelnemende lijsten}

Het aantal deelnemende lijsten per gemeente was in de communalistische periode in de provincie Limburg relatief groot. Dit blijkt uit tabel 3.3, waarin de verschillen te zien zijn tussen het gemiddeld aantal deelnemende lijsten per gemeente in Limburg en in Nederland als geheel, bij de gemeenteraadsverkiezingen in 1974 en $1978 .{ }^{2}$

Dit hoge gemiddelde in Limburg is opmerkelijk, gelet op het feit dat landelijke lijsten in 1974 nog nauwelijks en in 1978 slechts op beperkte schaal in Limburgse gemeenten vertegenwoordigd waren, zoals bleek uit het overzicht van de spreidingsgraad van deze lijsten. Het hoge gemiddelde betekent dat er veelal een groot aantal verschillende, met elkaar concurrerende plaatselijke groeperingen aan verkiezingen deelnam.

Tabel 3.3. Gemiddeld aantal bij gemeenteraadsverkiezingen ingediende lijsten per gemeente, in Limburg en Nederland, 1974-1978.

\begin{tabular}{lcc}
\hline & 1974 & 1978 \\
\hline Limburg & 6,6 & 6,3 \\
Nederland & 5,9 & 5,6 \\
\hline
\end{tabular}

Bron: CBS, Statistieken der Verkiezingen

\section{Opkomst}

Het grote aantal deelnemende lijsten geeft aan dat er sprake was van een sterke electorale concurrentie bij de raadsverkiezingen. Dat de kiezers zich bij die concurrentie betrokken voelden wordt geïndiceerd door de opkomstcijfers. In tabel 3.4 geven wij een overzicht van de opkomst van Limburgse kiezers in de jaren zeventig, gerelateerd aan het landelijk gemiddelde bij verkiezingen voor de Tweede Kamer, Provinciale Staten en gemeenteraden. Alle verkiezingen sinds de afschaffing van de opkomstplicht in 1970 tot aan het einde van de communalistische periode zijn daarin opgenomen.

2 Gegevens over eerdere jaren zijn niet opgenomen in de CBS Statistieken der Verkiezingen. 
Tabel 3.4. Opkomst bij verkiezingen voor de Tweede Kamer, Provinciale Staten en gemeenteraden in Limburg en Nederland, 1970-1978, (als percentage: van het totaal aantal kiesgerechtigden).

\begin{tabular}{llll}
\hline & Limburg & Nederland & verschil \\
\hline PS70 & 62,5 & 68,1 & $-5,6$ \\
GR70 & 73,2 & 67,2 & $+6,0$ \\
TK71 & 73,4 & 79,1 & $-4,7$ \\
TK72 & 77,3 & 83,5 & $-6,2$ \\
PS74 & 66,8 & 74,5 & $-7,7$ \\
GR74 & 71,6 & 69,1 & $+2,5$ \\
TK77 & 83,0 & 88,0 & $-5,0$ \\
PS78 & 74,7 & 79,6 & $-4,9$ \\
GR78 & 75,2 & 73,7 & $+1,5$ \\
\hline
\end{tabular}

PS = Verkiezingen voor Provinciale Staten; GR = Verkiezingen voor gemeenteraden; TK = Verkiezingen voor de Tweede Kamer.

Bron: CBS, Statistieken der Verkiezingen en ANP (PS91)

In overeenstemming met de landelijke cijfers, was ook in Limburg de kiezer het meest geneigd om naar de stembus te gaan bij Tweede Kamerverkiezingen. De opkomst bij deze verkiezingen lag in Limburg echter beduidend onder het landelijk gemiddelde. Ook de provinciale verkiezingen kenden in Limburg een relatief lage opkomst. Dit gold echter niet voor de gemeenteraadsverkiezingen. De belangstelling hiervoor lag in deze periode steeds boven het landelijk gemiddelde. Bovendien was de opkomst bij raadsverkiezingen in Limburg in 1970 en in 1974 hoger dan de opkomst bij Statenverkiezingen in die zelfde jaren. In de meeste andere provincies was dat niet het geval (Van Tilburg en Ohlenforst, 1991:173-174).

\section{Voorkeurstemmen}

Een ander aspect van raadsverkiezingen waarbij sprake is van een Limburgse afwijking van het landelijk gemiddelde, vormt het aantal kiezers dat voorkeurstemmen uitbrengt. Wanneer er relatief weinig stemmen op de lijssttrekker worden uitgebracht dan kan men daaruit afleiden dat veel kiezers niet alleen een voorkeur voor een bepaalde lijst, maar ook bewust een voorkeur voor een bepaalde persoon kenbaar maken. In tabel 3.5 zijn de percentages voorkeurstemmen in de provincie Limburg en in Nederland als geheel weergegeven in de verkiezingsjaren 1974 en 1978. ${ }^{3}$

In beide verkiezingsjaren werden er in Limburg bijna twee maal zoveel voorkeurstemmen uitgebracht als in Nederland als geheel. In hoofdstuk 5 gaan wij uitvoeriger op dit onderwerp in.

\section{Samenvatting}

Samengevat constateren wij de volgende kenmerken van Limburgse gemeenteraadsverkiezingen in de communalistische periode:

3 Gegevens over eerdere jaren zijn niet opgenomen in de CBS Statistieken der Verkiezingen. 
Tabel 3.5. Aantal niet op de eerste kandidaat uitgebrachte stemmen als percentage van het totaal aantal uitgebrachte stemmen bij gemeenteraadsverkiezingen in Limburg en Nederland, 1974-1978.

\begin{tabular}{lll}
\hline & 1974 & 1978 \\
\hline Limburg & 51,7 & 52,8 \\
Nederland & 26,3 & 27,0 \\
\hline
\end{tabular}

Bron: CBS, Statistieken der Verkiezingen

- In vrijwel alle gemeenten deden lokale lijsten mee aan de verkiezingen, terwijl de landelijke lijsten in circa 80 procent van de gemeenten niet op het stembiljet voorkwamen.

- De plaatselijke politieke groeperingen behaalden gezamenlijk tussen de 77 en 87 procent van de Limburgse raadszetels.

- Het aantal deelnemende lokale lijsten per gemeente was in de jaren zeventig hoog, waardoor het gemiddeld aantal deelnemende lijsten, ondanks de geringe deelname van landelijke lijsten, boven het landelijk gemiddelde lag.

- De opkomst bij boven-lokale verkiezingen na afschaffing van de opkomstplicht lag in Limburg relatief laag; bij gemeenteraadsverkiezingen scoorde deze provincie daarentegen juist hoger dan het landelijk gemiddelde.

- Er werden in Limburg bij gemeenteraadsverkiezingen in de jaren zeventig relatief veel voorkeurstemmen uitgebracht, waaruit is op te maken dat de verkiezingen een sterk persoonlijk karakter hadden.

Om meer inzicht te krijgen in de onderlinge samenhang en achtergronden van deze kenmerken gaan wij in de volgende paragraaf nader in op de communalistische traditie in Limburg.

\subsection{Achtergronden van de communalistische traditie}

In de vorige paragraaf is de in de periode tot 1978 beperkte deelname van landelijke politieke partijen aan de Limburgse lokale politiek zichtbaar geworden. Hoe kan deze situatie verklaard worden?

Gelet op de electorale verhoudingen in Limburg is het noodzakelijk om onderscheid te maken tussen enerzijds de positie van de KVP en anderzijds die van de overige landelijke partijen. Aan de hand van de uitslagen bij boven-lokale verkiezingen is vast te stellen dat de kans op het verwerven van één of meer zetels in de raad voor deze overige partijen in de meeste gemeenten niet erg groot was te achten.

Bij de Statenverkiezingen van 1966 zette zich een scherpe daling in voor de KVP, waarvan vooral de PvdA, maar ook de VVD en enkele andere partijen konden profiteren (zie het vorige hoofdstuk). De gevolgen van deze electorale ontwikkeling waren in de beginfase van de ontzuiling vooral in de stedelijke gemeenten merkbaar. 
Daar namen de niet-confessionele partijen al langer aan raadsverkiezingen deel en konden ze nu hun zeteltal beduidend uitbreiden.

Op het platteland kregen de veranderingen van kiezersvoorkeuren met enige vertraging eveneens gevolgen voor de lokale politieke verhoudingen. In gemeenten waar men gelet op de uitslag bij boven-lokale verkiezingen en de omvang van de plaatselijke kiesdrempel perspectief kreeg op het behalen van raadszetels, was het vervolgens noodzakelijk dat er voldoende leden waren om een eigen kandidatenlijst te kunnen vormen. Naast het beperkte aantal potentiële kiezers, kan het gebrek aan leden en daarmee potentieel partij-kader op het Limburgse platteland als een tweede handicap voor niet-confessionele landelijke partijen worden beschouwd.

De verklaring voor het achterwege blijven van KVP-lijsten moet daarentegen gezocht worden bij de motieven van zowel het Limburgse KVP-kader, als de lokale politici, om voor handhaving van die situatie te kiezen. Voor beide categorieën zijn verschillende argumenten te formuleren die de conclusie rechtvaardigen dat deelname van KVP-lijsten aan gemeenteraadsverkiezingen niet wenselijk zou zijn.

Voor het KVP-kader kunnen drie redenen genoemd worden. In de eerste plaats ontbrak een belangrijke prikkel om de politieke verhoudingen in gemeenten drastisch te gaan wijzigen, aangezien de aanhang van de KVP bij boven-lokale verkiezingen zeer stabiel was. Er was sprake van een (naar het leek hecht verankerd) 'pre-dominant party system' (Sartori, 1976:85). Andere landelijke partijen waren niet in staat om zich lokaal te manifesteren zodat de noodzaak om het eigen electoraat daartegen af te schermen niet bestond (Dittrich, 1978:114).

Een aanwijzing voor de werking van deze faktor is het feit dat in gemeenten waar de bedreiging door met name de PvdA wel werd gevoeld, KVP-lijsten ofwel katholieke 'eenheidslijsten' als aanloop naar een KVP-lijst optraden, (bijvoorbeeld in Sittard, (Boogers en Keizers, 1991) en Roermond (Quanjel, 1988)). De door de provinciale afdeling gestimuleerde pogingen tot deelname van een dergelijke eenheidslijst hielden echter veelal geen stand op het moment dat die bedreiging minder reëel bleek dan men aanvankelijk had gedacht.

Een tweede reden waarom een dringende noodzaak voor KVP-deelname in de meeste gemeenten ontbrak vormde het feit dat men er in de periode van verzuiling van uit kon gaan dat het overgrote deel van de plaatselijke politici, evenals de Limburgse kiezers, een onderdeel vormde van de katholieke zuil. Hoe pluriform de profilering van de verschillende lijsten ook was, de gemeenschappelijke katholieke achtergrond was gewoonlijk wel voorhanden.

Onduidelijk is in hoeverre de KVP-Limburg de formatie van KVP-lijsten ook bewust heeft ontmoedigd op grond van het feit dat men deelname aan de lokale politiek niet raadzaam vond. Dittrich suggereert dat dit het geval is geweest, verwijzend naar de beduchtheid voor dissidentisme en de mogelijke repercursies daarvan op het KVP-resultaat bij provinciale en landelijke verkiezingen in de betreffende gemeente (Dittrich, 1978:120). Deze angst voor dissidentisme levert een mogelijke derde reden op.

De kans op dissidentisme moet overigens inderdaad groot geacht worden aangezien de lokale politici gewoonlijk sterk verdeeld waren, (vgl. Custers, 1988; Ohlenforst, 
1992.) In het algemeen geldt dat er bij gebrek aan electorale concurrentie gewoonlijk een tendens bestaat in de richting van vermindering van partij-eenheid (Sartori, 1976:86).

\section{Weerstanden van lokale politici}

Voor de lokale politici zijn, nog afgezien van de genoemde verdeeldheid, eveneens verschillende redenen aan te geven op grond waarvan een samengaan in één KVP-lijst voor hen niet aantrekkelijk was. Een pragmatische reden om niet mee te werken aan het opzetten van een KVP-lijst hangt samen met de door de betreffende politicus ingeschatte gevolgen voor zijn kans op het raadslidmaatschap, c.q. het wethouderschap.

Dit motief was overigens ook in de jaren tachtig nog voorhanden, blijkens de mondelinge lijsttrekkersenquête. Eén van de geënquêteerde lijsttrekkers van een lokale lijst verwoordde dit als volgt:

"Ik zat in de raad en wilde dit continueren. Zou ik me bij een landelijke lijst aansluiten, dan zou het risico groot zijn dat ik op een onverkiesbare plaats zou komen te staan. Om dit risico te verkleinen kwam ik met een eigen lokale lijst uit. De mensen kennen mij immers en weten hoe ik werk. Ik kan zeker zijn van een vaste aanhang die mij een zetel op zal brengen."

Gelet op de eigen status en herkenbaarheid naar de kiezers toe, prefereerden deze lijsttrekkers het lijsttrekkerschap van een eigen lijst boven een onzekere, door de leden bij stemming vastgestelde plaats, ergens op de katholieke eenheidslijst. Zeker waar kiezers in belangrijke mate voor personen kozen en niet voor partijen of lijsten, zal een populaire politicus niet snel geneigd zijn geweest om een eigen lijst op te geven.

Een principiëler argument tegen deelname onder landelijke noemer komt voort uit de overtuiging dat de landelijke politieke partijen niet thuishoren in de lokale politiek. Een partijpolitieke verbinding tussen het lokale en boven-lokale niveau werd als een bedreiging van de onafhankelijkheid van de lokale groepering gezien.

Ook deze opvatting was terug te vinden in de antwoorden van Limburgse lijsttrekkers van lokale lijsten op de vraag waarom men bij de raadsverkiezingen van 1982 niet had deelgenomen onder de vlag van de partij waarop men bij de Tweede Kamerverkiezingen van datzelfde jaar had gestemd. Bij wijze van illustratie zijn hieronder enkele typerende antwoorden weergegeven.

"Landelijke politiek wordt vaak uitgespeeld in de Raad. Dat is niet goed voor de burger, daarom lokale lijsten."

"In een dorpsgemeenschap hoort geen politieke partij thuis. Voor mij kan dat niet werken."

"Omdat ik dan geen dorpspolitiek kan voeren in de goede zin des woords. Dorpspolitiek is geen vies woord, het is een mooi woord. Ik wil me niet conformeren aan de partijbelangen."

"Ik ben mezelf en ik ben het zelfs met het CDA niet eens. Een gemeente is het best in staat om zelf uit te maken wat goed is, niet de grote broer in Den Haag."

"Ik ben a-politiek."

"Dat zou betekend hebben dat er maar eén partij in ons dorp zou zijn. Dat trok niemand hier aan." 
Uit deze antwoorden blijkt dat een aantal lijsttrekkers van lokale lijsten het gevoel had dat lokale politiek los moest worden gezien van landelijke partijvorming. Er bestond geen behoefte om zich in partij-politiek of ideologisch opzicht te profileren. In dit verband lijkt een constatering van Sartori ook voor Limburg op te gaan: "Ideology does not strike roots in all types of soil" (Sartori, 1976:247).

Uit de hierboven aangehaalde citaten blijkt eveneens de grote waarde die werd gehecht aan de onafhankelijke status van de lijst. De politieke standpuntbepaling werd niet beïnvloed of bepaald door landelijke of provinciale instanties. Dit onafhankelijke, uitsluitend op de lokale situatie gerichte profiel sloot aan bij de sterke oriëntatie op de eigen lokale gemeenschap van een groot deel van het Limburgse electoraat (zie paragraaf 2.4).

De hierboven genoemde mogelijke verklaringen voor de af wezigheid van landelijke partijen in de Limburgse lokale politiek vertonen een duidelijke overeenkomst met de door Grant genoemde oorzaken voor communalisme in enkele Britse regio's (Grant, 1977:10 e.v.) Ook daar werd een zekere vijandige houding ten opzichte van politieke partijen gesignaleerd en in verband gebracht met gevestigde tradities van 'localism', dat wil zeggen een sterk gemeenschapsgevoel, en 'suspicion of outsiders'. Daarnaast was ook in die regio's bij boven-lokale verkiezingen sprake van een zeer grote meerderheid voor één partij, de conservatieven. Evenals in Limburg kwam er een einde aan de communalistische lokale politiek door de introduktie van de conservatieve partij, op het moment dat die meerderheidspositie onder druk kwam te staan en andere landelijke partijen terrein wonnen.

Aan de wijze waarop deze verandering zich in Limburg heeft voltrokken, is het resterende deel van dit hoofdstuk gewijd.

\subsection{Nationalisering van de Limburgse lokale politiek}

In de tweede helft van de jaren zeventig en met name in het begin van de jaren tachtig zijn de lokale politieke verhoudingen in Limburg drastisch gewijzigd. In deze paragraaf wordt deze wijziging aan de hand van verkiezingsstatistieken belicht, waarbij achtereenvolgens aan de orde komen; de zetelverdeling en de spreiding van de verschillende typen lijsten, de politieke verhoudingen binnen de gemeenten, het aantal deelnemende lijsten, de opkomstpercentages en het aantal voorkeurstemmen.

\section{Zetelverdeling}

In aanvulling op tabel 3.1 wordt in tabel 3.6 een overzicht gegeven van de politieke verhoudingen bij Limburgse gemeenteraadsverkiezingen, geïndiceerd door de aantallen raadszetels die door de verschillende typen lijsten werden verworven, in de periode 1978 tot 1990.

Uit dit overzicht blijkt dat de landelijke lijsten vooral in 1982 hun aandeel in de Limburgse gemeenteraadszetels sterk hebben zien toenemen. In 1986 wisten de lokale lijsten hun positie min of meer te handhaven, maar in 1990 moesten zij opnieuw een stap achteruit doen. 
Tabel 3.6. Door politieke groeperingen behaalde raadszetels bij de Limburgse raadsverkiezingen, 1978-1990.

\begin{tabular}{lrrrr}
\hline & 1978 & 1982 & 1986 & 1990 \\
\hline CDA & $15,9 \%$ & $33,5 \%$ & $30,6 \%$ & $35,7 \%$ \\
& $(212)$ & $(350)$ & $(323)$ & $(343)$ \\
PvdA* & $7,6 \%$ & $8,3 \%$ & $14,4 \%$ & $15,6 \%$ \\
& $(102)$ & $(87)$ & $(151)$ & $(150)$ \\
VVD & $4,1 \%$ & $7,6 \%$ & $7,7 \%$ & $6,4 \%$ \\
& $(55)$ & $(80)$ & $(81)$ & $(61)$ \\
D66 & $0,3 \%$ & $1,6 \%$ & $0,8 \%$ & $2,1 \%$ \\
& $(4)$ & $(17)$ & $(8)$ & $(20)$ \\
LC/GL** & $1,3 \%$ & $1,4 \%$ & $0,6 \%$ & $2,1 \%$ \\
& $(18)$ & $(15)$ & $(6)$ & $(20)$ \\
SP & & & $0,1 \%$ & $0,4 \%$ \\
& & & $(1)$ & $(4)$ \\
Totaal landelijke & $29,2 \%$ & $52,4 \%$ & $54,2 \%$ & $62,3 \%$ \\
lijsten & $(391)$ & $(549)$ & $(569)$ & $(598)$ \\
& & & & \\
Lokale lijsten & $70,4 \%$ & $47,6 \%$ & $45,8 \%$ & $37,7 \%$ \\
& $(947)$ & $(498)$ & $(480)$ & $(362)$ \\
& & & $100 \%$ & $100 \%$ \\
Totaal aantal zetels & $(1338)$ & $(1047)$ & $(1049)$ & $(960)$ \\
\hline
\end{tabular}

* Inclusief PAK in gemeenten waar de PvdA niet met een eigen lijst deelnam; ** LC is een combinatie van (leden van) D66, PPR, PSP en/of CPN, maar zonder PvdA; GL staat voor de sinds 1990 deelnemende partij Groen Links.

Bron: CBS, Statistieken der verkiezingen

Zowel in 1982 als in 1990 was er voor het CDA sprake van een forse uitbreiding van het aantal vertegenwoordigers in gemeenteraden. De PvdA boekte met name in 1986 zetelwinst. Aan het eind van de in deze studie geanalyseerde periode bezette het CDA ruim een derde van de Limburgse raadszetels. De PvdA kwam als tweede landelijke partij uit op ruim 15 procent van het totaal aantal zetels. De overige landelijke partijen bleven daar tamelijk ver onder.

Met deze ontwikkeling zijn de politieke verhoudingen - met name de verhouding tussen lokale en landelijke lijsten - bij gemeenteraadsverkiezingen in Limburg minder afwijkend geworden ten opzichte van de verhoudingen in andere provincies. De verschillen op dit punt tussen de twee zuidelijke provincies Noord-Brabant en Limburg en de overige provincies, zijn echter ook in 1990 nog aanzienlijk. Dit blijkt uit een vergelijking van het percentage door lokale lijsten verworven gemeenteraadszetels in de diverse provincies in tabel 3.7. 
Tabel 3.7. Percentage door lokale lijsten behaalde raadszetels per provincie, bij gemeenteraadsverkiezingen 1978-1990.

\begin{tabular}{lrrrr}
\hline & 1978 & 1982 & 1986 & 1990 \\
\hline Groningen & 7,2 & 9,7 & 8,5 & 6,0 \\
Friesland & 12,1 & 13,1 & 10,7 & 12,9 \\
Drente & 11,0 & 12,1 & 12,6 & 16,6 \\
Overijssel & 8,3 & 8,3 & 7,0 & 9,7 \\
Noord Holland & 19,0 & 15,3 & 10,9 & 11,5 \\
Zuid Holland & 6,1 & 6,8 & 5,9 & 5,7 \\
Utrecht & 6,3 & 5,6 & 6,2 & 6,4 \\
Flevoland & & & 5,4 & 4,4 \\
Gelderland & 19,0 & 15,3 & 12,8 & 13,9 \\
Zeeland & 15,2 & 13,2 & 10,8 & 11,7 \\
Noiord Brabant & 45,3 & 42,3 & 36,2 & 36,0 \\
Limburg & 70,4 & 47,6 & 45,8 & 37,7 \\
Nederland & 22,8 & 18,6 & 16,9 & 17,1 \\
\hline
\end{tabular}

Bron: CBS, Statistieken der verkiezingen

Tabel 3.8. Limburgse gemeenten naar deelname van enkele landelijke lijsten en lokale lijsten aan gemeenteraadsverkiezingen 1978-1990.

\begin{tabular}{lcccc}
\hline Gemeenten met: & 1978 & 1982 & 1986 & 1990 \\
\hline CDA-lijst & $15 \%$ & $81 \%$ & $86 \%$ & $95 \%$ \\
PvdA-lijst* & $29 \%$ & $61 \%$ & $70 \%$ & $93 \%$ \\
VVD-lijst & $33 \%$ & $57 \%$ & $64 \%$ & $73 \%$ \\
Lokale lijst(en) & $99 \%$ & $99 \%$ & $97 \%$ & $88 \%$ \\
$\begin{array}{llll}\text { Gremeenten zonder } \\
\text { landelijke lijst }\end{array}$ & $59 \%$ & $17 \%$ & $12 \%$ & $2 \%$ \\
$\begin{array}{l}\text { Totaal aantal } \\
\text { gemeenten }\end{array}$ & $(104)$ & $(69)$ & $(69)$ & $(56)$ \\
\hline
\end{tabular}

* Inclusief PAK in gemeenten waar de PvdA niet met cen eigen lijst deelnam.

Bron: CBS, Statistieken der verkiezingen, voor 1978 gecorrigeerd aan de hand van gegevens ANP

\section{Spreiding van lijsten}

Aan deze snelle electorale neergang van lokale lijsten lag een aanzienlijke uitbreiding van het aantal lijsten van landelijke partijen ten grondslag. Het aantal gemeenten waarin deze partijen op het stembiljet voorkwamen nam in de jaren zeventig en vooral in het begin van de jaren tachtig sterk toe. 
In de jaren zeventig waren de PvdA en de VVD in staat om ook in kleinere gemeenten met eigen lijsten uit te komen. Met name bij de verkiezingen van 1982 breidde de spreidingsgraad van deze twee partijen, maar ook van het CDA, zich sterk uit. Tabel 3.8 laat deze groeiende deelname van deze drie landelijke lijsten aan gemeenteraadsverkiezingen in Limburg zien. ${ }^{4}$

De PvdA en de VVD hadden - min of meer gelijk opgaand - het aantal eigen lijsten al in 1974 en 1978 verhoogd (zie tabel 3.2). Bij de verkiezingen van 1982 volgde een zeer sterke uitbreiding van het aantal gemeenten waarin deze partijen aan de verkiezingen deelnamen. In 1986 was er nog een lichte stijging, terwijl in 1990 de deelname van de PvdA opnieuw aanzienlijk toenam, met name in het herindelingsgebied Midden-Limburg. De VVD bleef bij die ontwikkeling wat achter.

$\mathrm{Bij}$ het CDA was sprake van een inhaalmanoeuvre. In 1978 deed deze partij slechts mee aan raadsverkiezingen in 15 procent van de gemeenten, beduidend minder dan de twee andere partijen. Vier jaar later waren er christen-democratische lijsten in 80 procent van de Limburgse gemeenten. Alleen in een aantal kleine Midden- en Noordlimburgse gemeenten kwam het CDA in 1986 nog niet met een eigen lijst uit. In 1990 was de deelname van het CDA compleet, op de kleine gemeenten Broekhuizen, Kessel en Thom na.

In tabel 3.8 werd de spreidingsgraad van de partijen apart weergegeven. Uit tabel 3.9 is af te lezen dat de KVP en haar opvolger het CDA in een aantal gemeenten haar intrede deed, vier jaar nadat de PvdA en/of de VVD dat voor het eerst hadden gedaan. Pas in 1982 heeft het CDA het initiatief niet langer aan de andere twee partijen gelaten.

Het feit dat het CDA tot in 1982 in geen enkele gemeente als enige landelijke partij naar voren trad, maar steeds samen met, of pas na andere landelijke partijen haar intrede in de gemeentepolitiek deed, vormt een bevestiging van de in de vorige paragraaf gegeven verklaring voor niet-deelname van deze partij. Pas op het moment dat de confessionele positie in een gemeente onder druk kwam te staan door (dreigende) deelname van de PvdA en/of de VVD, werd de tijd rijp geacht om met een eigen CDA-lijst uit te komen.

In 1982 slaagde het CDA er echter in om qua spreiding een voorsprong te nemen op PvdA en VVD. In dat jaar was er vrijwel geen enkele gemeente meer, waarin de PvdA en/of de VVD zonder concurrentie van het CDA aan de gemeenteraadsverkiezingen deelnamen, terwijl het omgekeerde in 10 gemeenten het geval was.

\section{Gevolgen herindeling}

De gemeentelijke herindelingen in Zuid-Limburg (in 1982) en in Midden-Limburg (in 1990) vormden voor de landelijke partijen een belangrijke impuls om de lokale activiteiten sterk uit te breiden. In een aantal opzichten was deze herindeling voor hen gunstig.

De schaalvergroting die werd gerealiseerd vergrootte de mogelijkheid tot het vormen van eigen afdelingen en lijsten door een samenvoeging van leden uit de tot dan

4 Gelet op hun geringe deelname zijn de overige kleinere landelijke partijen bij deze analyse buiten beschouwing gelaten. 
Tabel 3.9. Limburgse gemeenten naar deelname van (combinaties van) landelijke lijsten aan raadsverkiezingen 1970-1986.

\begin{tabular}{|c|c|c|c|c|c|c|}
\hline & 1970 & 1974 & 1978 & 1982 & 1986 & 1990 \\
\hline$C D A^{*}-P v d A^{* *}$-VVD & D 4 & 6 & 14 & 33 & 42 & 39 \\
\hline CDA & - & - & - & 10 & 11. & 2 \\
\hline CDA-PvdA & 2 & - & 1 & 8 & 5 & 11 \\
\hline CDA-VVD & - & - & 1 & 5 & 1 & 1 \\
\hline PvdA & 9 & 10 & 8 & - & - & 1 \\
\hline VVD & 1 & 8 & 12 & - & 1 & 1 \\
\hline PvdA-VVD & 2 & 6 & 7 & 1 & - & - \\
\hline $\begin{array}{l}\text { Gemeenten zonder } \\
\text { landelijke lijst }\end{array}$ & 84 & 68 & 60 & 12 & 9 & 1 \\
\hline $\begin{array}{l}\text { Totaal aantal } \\
\text { gemeenten }\end{array}$ & 104 & 104 & 104 & 69 & 69 & 56 \\
\hline
\end{tabular}

(Leesvoorbeeld: In 1978 waren er 13 gemeenten waarin CDA, PvdA en VVD tegelijk meededen. In dat zelfde jaar was er geen enkele gemeente waarin het CDA als enige landelijke partij met een lijst uitkwam.)

* In 1970 en 1974 inclusief KVP en Combinatie Christelijke Partijen (CCP); ** Inclusief PAK in gemeenten waar de PvdA niet met een eigen lijst deelnam.

Bron: CBS, Statistieken der verkiezingen

toe vaak zeer kleine afzonderlijke gemeenten. Vooral PvdA en VVD die in Limburg over een bescheiden ledental beschikten, hebben van deze afgenomen versnipperiñg van hun (potentieel) kader geprofiteerd (Dittrich, 1983:49 en Kuiper/Van Tilburg/Korsten, 1991).

De herindeling bracht naast een bestuurlijke ook een politieke reorganisatie met zich mee 5 . Het absolute aantal kiezers dat nodig was om in de grotere gemeente een raadszetel te behalen steeg (maar procentueel gezien daalde de kiesdrempel). In de nieuwe gemeente bestond de raad uit minder leden dan de raden van de oude gemeenten bij elkaar opgeteld, zodat een groot aantal zittende raadsleden hoe dan ook moest opstappen.

Eén en ander vormde voor diverse lokale politici aanleiding om mee te werken aan op de gehele gemeente georiënteerde lijsten, al dan niet onder de vlag van een landelijke partij. Met name het CDA bleek in Zuid-Limburg in staat om een groot aantal lokale lijsten als het ware over te nemen. In de gemeenten Beek, Eijsden, Nuth, Schinnen en Stein, bijvoorbeeld, werden in 1982 tussen de vijf en tien raadsleden voor het CDA verkozen die in de voormalige gemeenten als raadslid voor een lokale lijst

5 Voor een casus-beschrijving van de politieke verhoudingen na herindeling in de gemeente Stein (Zuid-Limburg) zie: Zijlstra, 1989 en Kuiper, 1991:112 e.v. en voor een vergelijkbare casus-beschrijving van de Middenlimburgse gemeerite: Maasbracht: Bekkers, 1991. 
Tabel 3.10. Percentage gemeenten waarin lokale lijsten aan gemeenteraadsverkiezingen hebben deelgenomen, per provincie, in 1978-1990.

\begin{tabular}{lrrrr}
\hline & 1978 & 1982 & 1986 & 1990 \\
\hline Groningen & 70 & 70 & 68 & 60 \\
Friesland & 95 & 100 & 100 & 94 \\
Drente: & 85 & 79 & 77 & 88 \\
Overijssel & 77 & 68 & 58 & 80 \\
Flevoland & & & & 100 \\
Utrecht & 58 & 56 & 48 & 63 \\
Noord-Holland & 73 & 70 & 69 & 70 \\
Zuid-Holland & 66 & 55 & 58 & 69 \\
Gelderland & 74 & 75 & 67 & 71 \\
Zeeland & 67 & 50 & 43 & 87 \\
Noord-Brabant & 94 & 96 & 98 & 98 \\
Limburg & 99 & 96 & 97 & 88 \\
& & & & \\
Nederland & 79 & 75 & 74 & 80 \\
\hline
\end{tabular}

Bron: CBS, Statistieken der verkiezingen

waren opgetreden. In totaal betrof het in deze vijf gemeenten 33 herkozen raadsleden. In dezelfde gemeenten hadden slechts vier herkozen raadsleden een overstap van een lokale lijst naar de PudA gemaakt (in Stein en in Eijsden).

De spreidingsgraad van lokale lijsten bleef gedurende de hele periode echter hoog, dat wil zeggen dat in bijna alle gemeenten tenminste één lokale politieke groepering aan verkiezingen deelnam (zie tabel 3.8). Pas in 1990 was er in Limburg sprake van een duidelijke daling van de spreidingsgraad van lokale lijsten. In zeven Noordlimburgse gemeenten deed in dat jaar geen enkele lokale lijst meer aan de verkiezingen mee.

De spreidingsgraad van lokale lijsten in Limburgse gemeenten bleef in de eerste drie verkiezingsjaren van deze periode ook hoog in vergelijking met de meeste andere provincies, (zie tabel 3.10). 6

(De nog grotere spreiding van lokale lijsten in Friesland komt voort uit de categorisering van de FNP als lokale lijst.)

\section{Politieke verhoudingen in gemeenten}

De massale deelname van landelijke partijen aan Limburgse gemeenteraadsverkiezingen is voor deze partijen bepaald niet zonder electoraal succes gebleven. In een snel

6 De opvallende stijging van spreidingspercentages van lokale lijsten in een aantal provincies in 1990 is voor een deel terug te voeren op de gewijzigde indeling van protestants-christelijke groeperingen als confessionele groeperingen en daarmee de categorisering van deze groeperingen als lokale in plaats van landelijke lijsten. (Deze gewijzigde indeling is aan het begin van dit hoofdstuk besproken.) 
Tabel 3.11. Limburgse gemeenten naar politieke verhoudingen in de gemeenteraad, 1978-1990.

\begin{tabular}{lrrrr}
\hline Gemeenten met: & 1978 & 1982 & 1986 & 1990 \\
\hline meerderheid lokale lijsten & $88,5 \%$ & $62,3 \%$ & $52,2 \%$ & $33,9 \%$ \\
meerderheid landelijke lijsten & $11,5 \%$ & $37,7 \%$ & $47,8 \%$ & $66,1 \%$ \\
& & & & $100 \%$ \\
Totaal aantal gemeenten & $100 \%$ & $100 \%$ & $100 \%$ \\
& $(104)$ & $(69)$ & $(69)$ & $(56)$ \\
\hline
\end{tabular}

Bron: CBS, Statistieken der verkiezingen

Tabel 3.12. Meerderheidsposities voor afzonderlijke fracties in Limburg, 1974-1990.

\begin{tabular}{lrrrr}
\hline Gemeenten met: & 1978 & 1982 & 1986 & 1990 \\
\hline meerderheid CDA-fractie & $1,9 \%$ & $15,9 \%$ & $11,6 \%$ & $16,1 \%$ \\
meerderheid fractie lokale lijst & $6,7 \%$ & $1,4 \%$ & $4,3 \%$ & $3,6 \%$ \\
geen meerderheidsfractie & $91,4 \%$ & $82,7 \%$ & $84,1 \%$ & $80,3 \%$ \\
& $100 \%$ & $100 \%$ & $100 \%$ & $100 \%$ \\
Totaal aantal gemeenten & $(104)$ & $(69)$ & $(69)$ & $(56)$ \\
& & & \\
\hline
\end{tabular}

Bron: CBS, Statistieken der verkiezingen

Tabel 3.13. Limburgse gemeenten naar type grootste fractie in de gemeenteraad, 1978-1990.

\begin{tabular}{lrrrr}
\hline Gemeenten met als grootste fractie: & 1978 & 1982 & 1986 & 1990 \\
\hline CDA-fractie & $12,5 \%$ & $58,0 \%$ & $61,0 \%$ & $69,6 \%$ \\
PvdA-fractie & - & - & $4,3 \%$ & - \\
D66-fractie & - & $1,4 \%$ & $1,4 \%$ & - \\
Lokale fractie & $87,5 \%$ & $40,6 \%$ & $33,3 \%$ & $30,4 \%$ \\
& & & & $100 \%$ \\
Totaal aantal gemeenten & $100 \%$ & $100 \%$ & $100 \%$ \\
& $(104)$ & $(69)$ & $(69)$ & $(56)$ \\
\hline
\end{tabular}

Bron: CBS, Statistieken der verkiezingen

stijgend aantal gemeenteraden leidde dit ertoe dat de fracties van de landelijke lijsten gezamenlijk een meerderheid in de gemeenteraad verwierven. In tabel 3.11 is dit in kaart gebracht.

Een situatie die in de gehele periode vrij zelden voorkwam, is die waarbij én lijst een fractie in de gemeenteraad vormt die over een absolute meerderheid van het aantal raadszetels beschikt. Dit lukte alleen enkele lokale lijsten en lijsten van het CDA, zoals uit tabel 3.12 is af te lezen. 
Tabel 3.14. Gemiddeld aantal bij gemeenteraadsverkiezingen ingediende lijsten per gemeente, in Limburg en Nederland, 1978-1990.

\begin{tabular}{lllll}
\hline & 1978 & 1982 & 1986 & 1990 \\
\hline Limburg & 6,33 & 7,00 & 6,07 & 5,70 \\
Nederland & 5,61 & 5,77 & 5,10 & 5,36 \\
\hline
\end{tabular}

Bron: CBS. Statistieken der Verkiezingen

Tabel 3.15. Aantal bij raadsverkiezingen in 1978, 1982, 1986 en 1990 in Limburg ingediende lokale lijsten en gemiddeld aantal lijsten per gemeente, naar gemeentegrootte.

\begin{tabular}{llrrrr}
\hline & 1978 & 1982 & 1986 & 1990 \\
\hline$\leq 10.000$ inwoners & aantal lijsten & 401 & 148 & 107 & 40 \\
& gemiddeld & $(5,1)$ & $(4,1)$ & $(3,0)$ & $(2,1)$ \\
& aantal gemeenten & 79 & 36 & 36 & 19 \\
$10-20.000$ inwoners & aantal lijsten & 88 & 94 & 77 & 68 \\
& gemiddeld & $(6,3)$ & $(4,7)$ & $(3,9)$ & $(2,8)$ \\
& aantal gemeenten & 14 & 20 & 20 & 24 \\
$\geq 20.000$ inwoners & aantal lijsten & 47 & 53 & 57 & 34 \\
& gemiddeld & $(4,3)$ & $(4,1)$ & $(4,4)$ & $(2,7)$ \\
& aantal gemeenten & 11 & 13 & 13 & 13 \\
Totaal aantal lijsten & & 536 & 298 & 241 & 142 \\
& & $(5,2)$ & $(4,3)$ & $(3,5)$ & $(2,5)$ \\
& & 104 & 69 & 69 & 56 \\
Totaal aantal gemeenten & & & & & \\
\hline
\end{tabular}

Bron: ANP en opgaven gemeenten

Het percentage gemeenteraden met een meerderheidspositie voor één van de fracties is in 1982 weliswaar fors gestegen, maar daarna gestabiliseerd op een nog altijd tamelijk laag niveau. De toename in $1982 \mathrm{kwam}$ geheel voor rekening van het succes van een aantal CDA-lijsten. De lokale lijsten waren in de meeste gemeenten onderling te zeer verdeeld om met een lijst uit te komen die in staat zou zijn om een meerderheidspositie in de gemeenteraad te verwerven.

Om dezelfde reden moesten lokale lijsten in de meeste gemeenten ook de positie van grootste fractie aan het CDA afstaan. Tabel 3.13 laat zien in hoeveel gemeenten de verschillende typen lijsten de grootste fractie leveren. (In het geval twee fracties even groot waren, is de lijst met het grootste aantal stemmen als de grootste aangemerkt.)

Uit deze tabel blijkt dat het CDA erin is geslaagd om vanaf de verkiezingen van 1982 in ongeveer tweederde van de Limburgse gemeenten de strategisch belangrijke positie van grootste fractie in de raad te verwerven. Deze positie is onder andere van groot belang in het kader van de collegevorming. (Het effect van deze veranderde 
Tabel 3.16.a. Opgeheven, doorgaande en nieuwe Limburgse lokale lijsten bij de gemeenteraadsverkiezingen in 1986.

aantal lijsten 1982

opgeheven lijsten 1986

doorgaande lijsten 1986

nieuwe lijsten 1986

aantal lijsten 1986
298

122

176

65

241
$(73 \%)$

(27\%)

(100\%)

Tabel 3.16.b. Specificatie opgeheven Limburgse lokale lijsten bij de gemeenteraadsverkiezingen in 1986.

waarvan:

1. in 1982 niet-succesvolle lijsten

2. in 1982 succesvolle, met een landelijke lijst gefuseerde lijsten

3. in 1982 succesvolle, met andere lokale lijst(en) $9 \%$ gefuseerde lijsten

4. overige in 1982 succesvolle lijsten

$31 \%$

Bron: ANP en opgaven gemeenten

politieke verhoudingen op de samenstelling van de Limburgse colleges van $B$ en W komt in hoofdstuk 7 aan de orde.)

\section{Aantal deelnemende lijsten}

In de periode waarin de landelijke lijsten in aantal sterk toenamen, was er sprake van een tegenovergestelde tendens ten aanzien van het aantal deelnemende lokale lijsten. $\mathrm{Na}$ een groei in 1982 daalde het gemiddeld aantal per gemeente deelnemende lijsten in Limburg en nam het verschil met het landelijk gemiddelde af, zoals uit tabel 3.14 is af te lezen.

Uit tabel 3.15 blijkt dat in 1978 gemiddeld ruim vijf lokale lijsten per gemeente aan de raadsverkiezingen in Limburg deelnamen. In 1990 was dat gemiddelde gedaald tot 2,5. In absolute termen verminderde het aantal lokale lijsten tussen 1978 en 1990 van 536 tot 142 . Daarbij deden zich enkele met de gemeentegrootte samenhangende verschillen voor. In tabel 3.15 is dat voor de periode van 1978 (de laatste raadsverkiezingen voor de herindeling in Zuid-Limburg) tot en met 1990 in beeld gebracht.

De daling van het absolute aantal lokale lijsten is in belangrijke mate terug te voeren op de twee gemeentelijke herindelingen, ten gevolge waarvan het aantal kleine gemeenten sterk gereduceerd is. Naast deze absolute daling is er echter ook sprake van een halvering van het gemiddeld aantal per gemeente deelnemende lokale lijsten in de periode 1978-1990. Wanneer deze gemiddelden na 1978 niet gedaald zouden zijn, dan 
Tabel 3.17.a. Opgeheven, doorgaande en nieuwe Zuid- en Noordimburgse lokale lijsten bij de gemeenteraadsverkiezingen in 1990 .

aantal lijsten 1986

opgeheven lijsten 1990

doorgaande lijsten 1990

nieuwe lijsten 1990

aantal lijsten 1990
136

58

78

13

91
$(86 \%)$

$(14 \%)$

(100\%)

Tabel 3.17.b. Specificatie opgeheven Zuid- en Noordlimburgse lokale lijsten bij de raadsverkiezingen in 1990 .

\begin{tabular}{ll}
\hline $\begin{array}{l}\text { Aantal opgeheven lijsten } \\
\text { waarvan: }\end{array}$ & $100 \%$ \\
\hline $\begin{array}{l}\text { 1. in } 1986 \text { niet-succesvolle lijsten } \\
\text { 2. in } 1986 \text { succesvolle, met een landelijke lijst }\end{array}$ & $44 \%$ \\
$\begin{array}{l}\text { gefuseerde lijsten } \\
\text { 3. in } 1986 \text { succesvolle, met andere lokale lijst(en) } \\
\text { gefuseerde lijsten }\end{array}$ & $10 \%$ \\
\begin{tabular}{l} 
4. overige \\
\hline
\end{tabular} & $24 \%$ \\
\hline
\end{tabular}

Bron: ANP en opgaven gemeenten

waren er in 1990 nog ruim 300 lokale lijsten overgebleven. In werkelijkheid waren het er minder dan de helft van dat aantal.

\section{Analyse dalend aantal lokale lijsten}

De achtergronden van deze, althans niet direkt, op het verminderde aantal gemeenten terug te voeren daling van het aantal deelnemende lokale lijsten, is nader onderzocht. Om de effekten van de herindeling buiten deze analyse te houden, is gekeken naar de verkiezingen van 1986 (heel Limburg) en die van 1990 (alleen Noord- en Zuid-Limburg).

Nagegaan is hoeveel lokale lijsten er verdwenen, doorgingen dan wel bij de verkiezingen van 1986, respectievelijk 1990, voor het eerst optraden. Bij de verdwijnende lijsten is tevens, (voor zover informatie daarover beschikbaar was), nagegaan of er sprake was van een fusie van lokale lijsten, van het opgaan in een landelijke lijst, dan wel van het opheffen van de lijst om andere redenen. Bij deze laatste categorie is tenslotte nog een onderscheid gemaakt tussen lijsten die er wel in slaagden om in 1982 , respectievelijk 1986, een raadszetel te bemachtigen en lijsten die toen niet succesvol waren. In tabel 3.16 is een overzicht van deze gegevens voor de verkiezingen van 1986 gegeven.

De grootste groep lokale lijsten die in 1986 is afgehaakt betrof lijsten die in 1982 zonder succes aan de verkiezingen deelnamen. 
Het aantal fusies van lokale lijsten onderling en van lokale: met landelijke lijsten was op het totaal van 1982 vrij gering. Van het laatste type fusie profiteerde het CDA het meest. Negentien lijsten gingen op in deze partij. De gemeente: Meerlo-Wanssum vormde een uitschieter met vijf lokale lijsten die in 1986 tesamen onder de vlag van de christen-democraten uitkwamen. Voor zover dat kon worden nagegaan waren er in totaal zo'n veertig raadsleden van lokale lijsten die de overstap naar het CDA maakten. Vijf plaatselijke groeperingen gingen op in de VVD en drie in de PvdA.

Het ontstaan van een aantal van de in de tabel genoemde nieuwe lokale lijsten kwam overigens voort uit deze fusies. Met name onenigheid over de volgorde van kandidaten op de lijst, vormde de aanleiding voor verschillende kandidaten om een nieuwe eigen lijst uit te brengen. Dit deed zich in 1986 onder meer voor in Beek, Echt, Linne, Maasbracht, Stein, Venlo, Vlodrop, en Voerendaal.

Tenslotte was er een tamelijk grote restcategorie van lijsten met raadszetels die om andere redenen, (vaak samenhangend met de persoon van de lijsttrekker) in 1986 niet meer deelnam.

In tabel 3.17 is een overzicht gegeven van de ontwikkelingen in 1990. Het herindelingsgebied Midden-Limburg is daarbij, zoals vermeld, buiten beschouwing gelaten.

Ook in 1990 werd de grootste categorie afvallers gevormd door niet-succesvolle lijsten. Op één lijst na, deden alle lokale lijsten die in 1986 geen zetel hadden behaald, vier jaar later niet meer aan de verkiezingen mee. ${ }^{7}$

Het aantal wel succesvolle lijsten dat om andere redenen dan fusies afhaakte, was relatief kleiner dan in 1986. Van de 14 betreffende lijsten vormden er overigens 11 een eenmansfractie en drie een tweemansfractie in de periode 1986-1990. Het ging derhalve in deze categorie uitsluitend om - qua zeteltal kleine groeperingen - die gelet op hun afhankelijkheid van een enkele stemmentrekker - veelal bijzonder kwetsbaar waren.

Het aantal fusies tussen landelijke en lokale lijsten bleef in 1990 opnieuw beperkt. De 13 bij deze fusies betrokken plaatselijke politieke groeperingen beschikten in de voorgaande periode samen over 23 raadszetels, (ofwel 9 procent van het in 1986 door lokale lijsten behaalde aantal zetels). Het CDA was opnieuw het meest succesvol door fusies aan te gaan met 9 lokale groeperingen, waaronder enkele met grote fracties in de gemeenteraden van Meerssen en Tegelen. Afsplitsingen van het CDA vonden plaats in onder meer Stein en Brunssum. In beide gevallen vormde onenigheid over de volgorde op de kandidatenlijst daartoe de aanleiding.

De sterke wisselingen in de lokale partijstructuren met per verkiezing grote aantallen nieuwe en opgeheven lijsten, roept het beeld op van 'fluid politics', zoals Sartori een politieke situatie aanduidt waarbij de structurele consolidatie van een partijsysteem ontbreekt (Sartori, 1976:244 e.v.). Waar op provinciaal en nationaal niveau en in gemeenten elders in het land wel een dergelijke consolidatie in hoge mate voor handen was, bleef in Limburg het partijsysteem in veel gemeenten sterk in beweging. Op de achtergronden hiervan komen wij in de hoofdstukken 4 en 5 terug.

7 De enige uitzondering, de lijst Mager in Sittard, behaalde ook in 1990 geen raadszetel. 
Tabel 3.18. Opkomst bij verkiezingen in Limburg en Nederland, sinds 1978, als percentage van het totaal aantal kiesgerechtigde.

\begin{tabular}{lllc}
\hline & Limburg & Nederland & verschil \\
\hline PS78 & 74,7 & 79,6 & $-4,9$ \\
GR78 & 75,2 & 73,7 & $+1,5$ \\
EP79 & 51,7 & 58,1 & $-6,4$ \\
TK81 & 84,0 & 87,0 & $-3,0$ \\
PS82 & 60,4 & 68,4 & $-8,0$ \\
GR82 & 71,6 & 68,3 & $+3,3$ \\
TK82 & 74,9 & 81,0 & $-6,1$ \\
EP84 & 44,7 & 50,9 & $-6,2$ \\
GR86 & 75,1 & 73,2 & $+1,9$ \\
TK86 & 83,1 & 85,8 & $-2,7$ \\
PS87 & 63,3 & 66,3 & $-3,0$ \\
EP89 & 43,8 & 47,5 & $-3,7$ \\
TK89 & 76,9 & 80,3 & $-3,4$ \\
GR90 & 66,9 & 62,3 & $+4,6$ \\
PS91 & 47,8 & 52,1 & $-4,3$ \\
\hline
\end{tabular}

PS = Verkiezingen voor Provinciale Staten; $G R=$ Verkiezingen voor gemeenteraden; TK = Verkiezingen voor de Tweede Kamer; EP = Verkiezingen voor het Europees Parlement.

Bron: CBS, Statistieken der Verkiezingen en ANP (PS9I).

Tabel 3.19. Aantal niet op de eerste kandidaat uitgebrachte stemmen bij gemeenteraadsverkiezingen per provincie, 1974-1982.

\begin{tabular}{llllll}
\hline & 1978 & 1982 & & 1986 & 1990 \\
\hline Limburg & 52,8 & 56,4 & & 56,1 & 59,6 \\
Nederland & 27,0 & 28,4 & & onbekend & onbekend \\
\hline
\end{tabular}

Bron: CBS, Statistieken der Verkiezingen (1978 en 1982) en opgaven gemeenten (1986 en 1990)

Een aanwijzing voor een cok in de Limburgse lokale politiek toenemende consolidatie vormt het feit dat het percentage nieuwe lijsten op het totaal aantal ingediende lokale lijsten, alsmede het aantal met landelijke lijsten gefuseerde lokale lijsten, aan het eind van de hier geanalyseerde periode daalde.

\section{Opkomst}

De opkomst bij gemeenteraadsverkiezingen in Limburg gaf in deze periode hetzelfde beeld te zien als daarvoor. Bij gemeenteraadsverkiezingen was in vergelijking met andere provincies sprake van een bovengemiddelde opkomst. Voor 1978 en 1982 geldt bovendien dat in afwijking van het landelijke beeld de opkomst bij gemeente- 
raadsverkiezingen in Limburg hoger was, dan de opkomst bij Statenverkiezingen in hetzelfde jaar. Deze verschillen zijn terug te vinden in tabel 3.18.

Uit dit overzicht, gevoegd bij tabel 3.4, blijkt dat de opkomst bij Limburgse gemeenteraadsverkiezingen sinds 1970 schommelde tussen de 70 en 75 procent, behalve in 1990 toen sprake was van een diepterecord van nog geen 67 procent.

\section{Voorkeurstemmen}

Ook in de periode vanaf 1978 bleef het aantal bij gemeenteraadsverkiezingen uitgebrachte voorkeurstemmen in Limburg hoog. Tabel 3.19 geeft de betreffende percentages weer. ${ }^{8}$

\section{Samenvatting}

De in deze paragraaf behandelde, ingrijpende veranderingen die de lokale politieke verhoudingen in Limburg na 1974 hebben ondergaan, kunnen als volgt worden samengevat:

- Vanaf de jaren zeventig hebben PvdA en VVD het aantal aan de raadsverkiezingen deelnemende lijsten gestaag uitgebreid. Begin jaren tachtig volgde ook het CDA met de introductie van eigen lijsten in een groot aantal Limburgse gemeenten, waarbij diverse lokale lijsten konden worden 'overgenomen'.

- Een groot aantal lokale lijsten hield op te bestaan. In het begin van de jaren tachtig werden er ook veel nieuwe lijsten ingediend; aan het eind van de geanalyseerde periode nam het aantal nieuwe lijsten af. Het aantal aan de verkiezingen deelnemende lokale lijsten daalde gemiddeld in de jaren tachtig van ruim vijf naar nog geen drie per gemeente.

- In het merendeel van de gemeenten deden in 1990 zowel de drie grootste landelijke partijen als enkele lokale lijsten aan de verkiezingen mee.

- De landelijke lijsten verwierven samen sinds 1982 meer dan de helft van het aantal Limburgse raadszetels. In 1990 vormden raadsleden van landelijke lijsten in tweederde van de gemeenteraden een meerderheid in de raad.

- Van de landelijke lijsten was het CDA het meest succesvol met circa éenderde van de raadszetels. Deze partij vormde bovendien in ongeveer tweederde van de gemeenteraden de grootste fractie.

- De lokale lijsten hebben met name in 1982 een veer moeten laten maar hebben zich in 1986 zowel qua stemmenaantal als qua aantal zetels in de gemeenteraden redelijk weten te handhaven. In 1990 volgde echter in veel gemeenten een verdere afkalving van hun positie.

- In de periode die in het teken stond van nationalisering en gemeentelijke herindeling bleef zowel de opkomst als het percentage voorkeurstemmen bij gemeenteraadsverkiezingen in vergelijking met het landelijk gemiddelde in Limburg hoog.

8 Vanaf 1986 heeft het CBS geen gegevens meer verzameld over de uitgebrachte voorkeurstemmen bij gemeenteraadsverkiezingen. Voor de raadsverkiezingen van 1986 en 1990 zijn uitsluitend de Limburgse percentages berekend (op basis van de processen-verbaal van de raadsverkiezingen). 
Aan de monopolie-positie van lokale lijsten in de Limburgse lokale politiek is in bijna alle gemeenten een eind gekomen. De nationalisering van de lokale politiek heeft echter geenszins een einde gemaakt aan het verschijnsel lokale lijsten. In de meeste gemeenten vormden zij ook na de verkiezingen van 1990 nog steeds een factor van betekenis. 


\section{Hoofdstuk 4}

\section{Typologie, organisatie en functioneren van lokale politieke groeperingen}

\subsection{Inleiding}

Tot nu toe zijn lokale lijsten steeds als aparte categorie geclassificeerd en afgezet tegen landelijke lijsten. Bij die classificatie is voorbij gegaan aan de heterogeniteit die de groep van lokale lijsten kenmerkt.

Om meer zicht te krijgen op deze veelkleurigheid staan wij in de eerste paragraaf van dit hoofdstuk stil bij de vraag wat de doelstelling en motivatie van de verschillende lokale lijsten vormt. Door dat onderzoek ontstaat tevens inzicht in de redenen voor de versnippering en verdeeldheid van lokale lijsten, blijkend uit het gemiddeld grote aantal deelnemende lokale lijsten per gemeente.

Voor een nadere typering van lokale lijsten staan ons met name een tweetal bronnen ter beschikking. In verschillende Limburgse gemeenten zijn case-studies verricht naar de ontwikkelingen in de lokale politiek vanaf 1919, c.q. vanaf 1945. De aard van de scheidslijnen tussen de elkaar beconcurrerende lokale lijsten en de in de tijd plaats vindende verschuivingen op dat punt, vormden steeds een onderdeel van deze studies.

De tweede bron vormt de in 1986 uitgevoerde mondelinge lijsttrekkersenquête. Bij deze enquête zijn lijsttrekkers van vijfenvijftig lokale lijsten in vijftien Limburgse gemeenten gevraagd naar de motieven en doelstellingen van hun politieke groepering. Aan de hand van de antwoorden wordt een indeling gemaakt van verschillende typen lokale lijsten die in de jaren tachtig in Limburg optraden.

In de tweede paragraaf komt de wijze van organisatie en de mate van continuïteit van de lijsten aan de orde. Belangrijke vraag daarbij is in hoeverre lokale lijsten voldoen aan het gangbare organisatiepatroon van politieke partijen. Aan de hand van de resultaten van de lijsttrekkersenquête wordt een beeld geschetst van de wijze waarop lokale politieke groeperingen en plaatselijke afdelingen van landelijke partijen in Limburg georganiseerd zijn.

In de derde paragraaf wordt het onderzoek gericht op de verschillen tussen lokale en landelijke lijsten op het punt van het functioneren als politieke groeperingen. 
Daarbij gaat het om een tweetal kernfuncties van politieke partijen, te weten het opstellen van kandidatenlijsten en het formuleren van verkiezingsprogramma's. Ook bij dit onderwerp wordt geput uit de gegevens die de lijsttrekkersenquête heeft opgeleverd en vormen de lijsten de eenheid van analyse.

In de laatste paragraaf staan wij stil bij de recente en te verwachten ontwikkelingen ten aanzien van zowel de organisatie als het functioneren van met name de lokale lijsten.

\subsection{Typen lokale lijsten}

In het vorige hoofdstuk is er op gewezen dat het gemiddeld aantal aan de gemeenteraadsverkiezingen deelnemende lijsten per gemeente in Limburg relatief hoog is. In hoofdstuk 2 is vermeld dat er in deze provincie van oudsher weinig politiek-ideologische en religieuze verdeeldheid heerste. In de meeste gemeenten was men massaal aanhanger van de KVP bij boven-lokale verkiezingen en behoorde men vrijwel zonder uitzondering tot de katholieke kerk. De verdeeldheid van de politieke elite in Limburgse gemeenten berustte dan ook op andere dan politiek-ideologische en religieuze scheidslijnen.

Een viertal scheidslijnen die, gegeven het bovenstaande, in de Limburgse omgeving verwacht kunnen worden, zijn de volgende:

- persoonsgebonden scheidslijnen (gebaseerd op morele verbondenheid met, dan wel afhankelijkheid van bepaalde personen of families, die al dan niet onderlinge conflicten van persoonlijke aard hebben).

- territoriale scheidslijnen (gebaseerd op bijvoorbeeld dorpen, buurten of straten);

- sociaal-economische scheidslijnen (gebaseerd op beroepsgroepen, standen of klassen);

- 'culturele' scheidslijnen (gebaseerd op verenigingen zoals harmonieën, fanfares etc.);

Het samenvallen van dergelijke scheidslijnen ('mutually reinforcing cleavages' (Lijphart, 1979:172)) is goed denkbaar. Een voorbeeld is een groepering die in eerste instantie een bepaalde vereniging vertegenwoordigt. De leden van die vereniging kunnen vervolgens allen uit een bepaald kerkdorp of een bepaalde buurt afkomstig zijn, waarin bovendien een bepaalde beroepsgroep of klasse dominerend is. De betreffende lijst staat in dat geval niet alleen voor een dergelijke vereniging maar tevens voor een bepaalde buurt en een bepaalde stand. Ook kunnen mengvormen ontstaan doordat verschillende kandidaten op een lijst elk een eigen specifieke achterban inbrengen, die volgens verschillende scheidslijnen is aan te duiden.

Het bovenstaande theoretische onderscheid levert bij een poging tot toepassing daarvan in de praktijk echter een aantal moeilijkheden op.

Een voor de hand liggend criterium aan de hand waarvan een lijst in verband kan worden gebracht met een bepaalde scheidslijn zou de naamsaanduiding zijn. Zo kunnen lijsten die zich afficheren als 'werknemersbelangen', als (primair) sociaal-economisch worden bestempeld. Lijsten die de naam van een dorp of wijk voeren zijn 
waarschijnlijk gebaseerd op een territoriale scheidslijn. Het probleem daarbij is echter dat er dan nog een groot aantal lijsten over blijft, waarbij de naam geen uitsluitsel geeft over de categorie waartoe de lijst behoort. Dit geldt bijvoorbeeld voor namen als 'Algemeen Belang'. Ook zijn er veel lijsten zonder formele naamsaanduiding op het stembiljet. Deze lijsten worden gewoonlijk genoemd naar de eerste kandidaat op de lijst. Het zou niettemin onjuist zijn daaruit zonder meer te concluderen dat het lijsten betreft die primair verbonden zijn met persoonsgebonden scheidslijnen. Het kunnen typische stands-, kerkdorp- of verenigingslijsten zijn, zonder dat men het nodig acht om dit via een aparte naamgeving te laten blijken.

Een andere manier om na te gaan met welk type lijst men te doen heeft is te onderzoeken of de kandidaten en de kiezers van een bepaalde lijst zijn onder te brengen in een bepaald segment van de lokale samenleving. Bij deze methode probeert men de lijsten te typeren door de kenmerken van de politici en hun achterban te reconstrueren.

Bij een territoriale lijst kan men veronderstellen dat deze haar electorale basis vrijwel uitsluitend heeft in één kerkdorp, buurtschap of wijk en dat alle leden van de lijst ook op de betreffende plek wonen. Daarnaast zou men - om de aanwezigheid van andere mogelijke gepolitiseerde scheidslijnen uit te sluiten - alleen die lijsten als (uitsluitend) territoriaal moeten aanmerken die op hun eigen gebied geen concurrentie van andere lijsten ondervinden, die eveneens alleen in de betreffende kern actief zijn.

Dittrich heeft deze methode gebruikt in een onderzoek naar de aard van de lokale lijsten die in Zuid-Limburg aan de 'herindelingsverkiezingen' in 1981 deelnamen (Dittrich, 1983). Uit het onderzoek bleek dat van de 110 deelnemende lokale lijsten er 63 konden worden gekwalificeerd als 'lijsten die specifiek gericht zijn op éen kem binnen een gemeente' (Dittrich, 1983:52). Voor ongeveer de helft daarvan gold bovendien dat zij in 'hun' kern geen concurrentie ondervonden van een andere op die kem gerichte lokale lijst.' $\mathrm{Er}$ waren echter slechts 27 lijsten waarvoor gold dat alle kandidaten afkomstig waren uit dezelfde voormalige gemeenten.

Een interpretatie-probleem bij deze resultaten is de eerder vermelde mogelijkheid van elkaar versterkende, samenvallende scheidslijnen. In dat geval is het niet duidelijk in hoeverre andere dan territoriale tegenstellingen mede aanleiding tot lijstvorming zijn geweest. De woonplaats van kandidaten en kiezers is echter het enige kenmerk van deze personen dat relatief gemakkelijk te achterhalen is. Kenmerken die te maken hebben met andere mogelijke scheidslijnen zoals lidmaatschap van beroepsgroepen, verenigingen, familiaire en vriendschapsnetwerken kunnen daarentegen niet achterhaald worden aan de hand van processen-verbaal van de raadsverkiezingen.

Zowel enkele case-studies als de lijsttrekkersenquête hebben wat dat betreft meer resultaten opgeleverd.

1 Over deze cijfers zegt Dittrich overigens dat ze “op zijn allerbest gekwalificeerd kunnen worden als "intelligent guesses"'. Daaruit valt op te maken dat toepassing van deze methode niet gemakkelijk is geweest. 


\section{a. Resultaten case-studies}

In enkele case-studies is gepoogd om aan de hand van archiefmateriaal en interviews tot een beter gefundeerde typologie van lokale lijsten in de betreffende gemeenten te ontwikkelen. Over drie gemeenten verschenen aparte publikaties. De resultaten ten aanzien van de typen lokale lijsten in deze gemeenten, worden hieronder weergegeven. Het betreft monografieën over lokale politiek in respectievelijk Sint-Geertruid (Custers, 1988), Echt (Ohlenforst, 1992) en Sittard (Boogers en Keizers, 1991).

\section{Sint-Geertruid}

Het door Custers uitgevoerde onderzoek naar lokale politiek in de kleine, in 1982 opgeheven Zuidlimburgse gemeente Sint-Greertruid in de periode 1919-1982, laat zien dat de voor het systeem van lijsten aldaar bepalende scheidslijnen verre van stabiel waren.

In de periode tot 1935 waren er geen gepolitiseerde scheidslijnen en deed gewoonlijk slechts één lijst met zeven kandidaten (voor de zeven beschikbare raadszetels) aan de verkiezingen mee.

Tussen 1935 en 1958 stond de lokale politiek in het teken van persoonlijke tegenstellingen. Er deden veel lijsten mee, waarbij de lijsttrekkers verreweg de belangrijkste actoren waren. De verkiezingscampagnes waren uitermate fel en er werd veel 'op de man gespeeld'. De politici probeerden kiezers aan zich te binden door persoonlijke belangenbehartiging en vriendschapsnetwerken.

Aan het eind van de jaren vijftig deden standslijsten hun intrede. Deze lijsten waren primair gebaseerd op de scheidslijn tussen landbouwers en arbeiders. De arbeiders vormden een sterk groeiend deel van de beroepsbevolking. In de tot dan toe bestaande, door boeren en middenstanders beheerste politieke constellatie voelden zij zich onvoldoende gerepresenteerd. Er waren minder lijsten, de verkiezingscampagnes waren matter en kiezers wisselden minder snel in hun lijstvoorkeur. Volgens Custers waren dit indicatoren voor een verminderde electorale concurrentie.

In de jaren zeventig verdween de tegenstelling tussen landbouwers en arbeiders naar de achtergrond. De groei van de dienstensector maakte de beroepsbevolking heterogener. De toestroom van allochtonen versterkte deze toenemende pluriformiteit. De politiek-ideologische consensus verdween blijkens de uitslagen van Tweede Kamerverkiezingen in de gemeente. In 1959 stemde nog ruim 96 procent van de kiezers op de KVP. In 1971 was dat 20 procent minder en in 1981 haalde het CDA nog maar 56 procent van de uitgebrachte stemmen. Toch kregen de tegenstellingen tussen landelijke politieke partijen in de jaren zeventig nog geen lokale vertaling in Sint-Geertruid. ${ }^{2}$

2 Dit is overigens in strijd met de modemiseringshypothese van Huntington en Dominguez. Zij gaan ervan uit dat de ontwikkeling van een modeme massa-democratie globaal gesproken een drietal stadia doorloopt, waarin de politieke verhoudingen achtereenvolgens bepaald worden door persoonlijke bindingen tussen kiezers en lokale notabelen, door politieke organisaties die verbonden zijn aan sociaal-economische klassen en tenslotte door modeme politieke partijen (Huntington en Dominguez, 1975). (Voor een verklaring van de blijvende afwezigheid van 
Aan de basis van het lijstenstelsel lag de tegenstelling tussen twee groepen verenigingen, die van de gemeente allerlei faciliteiten verlangden. Deze nieuwe gepolitiseerde scheidslijn kwam als het ware bovenop de gedeeltelijk voortbestaande standenidentiteit. In deze fase leek de persoon van de lijsttrekker weer aan gewicht te hebben gewonnen. Er ontbrandde opnieuw een hevige strijd om de kiezers.

\section{Echt}

Kenmerkend voor de lokale politiek in de Middenlimburgse plattelandsgemeente Echt was en is de grote versnippering van de lokale lijsten. Per verkiezingsjaar deden sinds 1946 steeds tussen de zes en dertien verschillende lokale lijsten aan verkiezingen mee.

In afwijking van de situatie in Sint-Geertuid was er echter nauwelijks sprake van een duidelijke profilering van andere dan persoonsgebonden scheidslijnen. Alleen kort na de oorlog ontstonden er enkele standslijsten, met name een drietal arbeiderslijsten, die zich afzetten tegen de vooroorlogse door boeren, middenstanders en ondernemers gedomineerde politieke verhoudingen. In de jaren vijftig kregen de meeste lijsten een qua beroep van de kandidaten gemengd karakter en vormden de standstegenstellingen ook geen onderdeel meer van de profilering van de verschillende lijsten.

Ondanks het feit dat de gemeente Echt dertien verschillende kernen omvat, zijn uitsluitend aan één kem gebonden, territoriale lijsten zeldzaam en nauwelijks succesvol gebleken. De tegenstellingen tussen de kernen hebben geen stempel gezet op de lijstenstructuur in Echt. Op de meeste lijsten, na 1970 zelfs op alle, kwamen kandidaten uit verschillende dorpen voor. De verschillende verenigingen hebben evenmin een politieke vertaling in lokale lijsten gekregen.

Achtergrond voor het grote aantal verschillende lokale lijsten waren dan ook vooral persoonsgebonden scheidslijnen. Landelijke politieke partijen speelden ook in 1990 met vier van de zeventien raadszetels - nog slechts een bescheiden rol in de plaatselijke politiek.

\section{Sittard}

In de stedelijke gemeente Sittard werd de vooroorlogse lokale politiek gedomineerd door katholieke notabelen, die ofwel op een lijst van de Katholieke Kiesvereniging ofwel op een katholieke 'eenheidslijst' uitkwamen. Vanaf de jaren twintig traden verschillende dissidentenlijsten op, die zich tegen deze notabelen afzetten. Deze lijsten kwamen vooral voort uit persoonlijke tegenstellingen en conflicten over de lijstvolgorde op de eenheidslijst. De verschillende wijken of standen vormden bijna nooit een eigen lijst.

Ook na de oorlog vormden de katholieke standsorganisaties in de lokale politiek een tamelijk gesloten front achter de katholieke eenheidslijst. Opnieuw traden er echter enkele dissidentenlijsten op, waaronder ook lijsten die nauw gelieerd waren aan vakbonden. 
In de jaren zeventig kreeg daarnaast de tegenstelling tussen progressief en conservatief, oud en jong, een vertaling in de lijstenstructuur. De politieke verhoudingen waren aan het eind van de onderzoeksperiode bovendien in hoge mate genationaliseerd.

\section{Overige case-studies}

In verschillende andere gemeenten zijn case-studies verricht waarmee de uitkomsten van het onderzoek in Sint-Geertruid, Echt en Sittard kunnen worden vergeleken. ${ }^{3}$ Deze gemeenten zijn: Heer, Meerlo-Wanssum, Noorbeek, Roermond, Roosteren en Weert. Wat betreft het type lokale lijsten zien we een tweetal kenmerken die ook in de hiervoor behandelde case-studies gesignaleerd zijn, in verschillende van deze gemeenten terug:

- het gedurende een langere periode centraal staan van persoonlijke tegenstellingen binnen de politieke elite, (alle gemeenten, maar in het bijzonder, Noorbeek, Meerlo-Wanssum en Roosteren);

- het optreden van standslijsten in de jaren vijftig en zestig en de verbreding of afkalving van deze lijsten in de jaren zeventig.

Anders dan in de hierboven behandelde gemeenten is de lijstenstructuur in Roermond lange tijd vooral gebaseerd geweest op territoriale scheidslijnen. Met uitzondering van de vooroorlogse situatie in de (voormalige) gemeente Heer, hebben tegenstellingen tussen verenigingen in geen van de onderzochte gemeenten een politieke vertaling gekregen.

Evenals in Sittard zien wij tenslotte in de stedelijke gemeenten Weert en Roermond dat er in de jaren zeventig lokale lijsten werden geïntroduceerd die afstand namen van de heersende politieke cultuur en een zekere politisering en verjonging van de lokale politiek voorstonden.

Uit het laatst genoemde kenmerk blijkt dat niet alle lijsten zijn te classificeren met behulp van de in het begin van deze paragraaf genoemde vier scheidslijnen. In de jaren zeventig ontstond in een aantal gemeenten een nieuwe scheidslijn die te maken heeft met dimensies als 'oud versus jong', 'progressief versus conservatief', 'politisering versus depolitisering', en daardoor met verschillen van inzicht over bepaalde concrete beleidsthema's in de gemeentepolitiek. (Bij een vergelijkbare situatie in Engeland spreekt Grant van 'genuine policy conflicts' (Grant, 1978:16).) Kortheidshalve wordt dit snort lijsten hier getypeerd als vernieuwingsgezind.

Deze ontwikkeling ging in sommige gevallen vooraf of liep parallel aan de introduktie van landelijke lijsten, die eveneens bijdroeg aan de politisering van beleidsinhoudelijke en ideologisch getinte scheidslijnen.

3 De resultaten van deze case-studies zijn niet eerder gepresenteerd. Ze werden verricht in het kader van de activiteiten van de Werkgroep Lokale Politiek van de de Faculteit der Rechtsgeleerdheid te Maastricht. De betrokken onderzoekers waren P. Kunen, P. Pustjens, M. Rompelbeek, M. Verbeet (studenten) en R. Welten (wetenschappelijk assistent). 


\section{b. Resultaten lijsttrekkersenquête}

\section{Motieven voor deelname}

Op grond van de resultaten van de case-studies is het te verwachten dat de lokale lijsten in de jaren tachtig - waarop de lijsttrekkersenquête betrekking heeft - een zeer pluriform karakter vertoonden. Om er achter te komen welke scheidslijnen in de jaren tachtig actueel zijn geweest, is aan de lijsttrekkers gevraagd naar de motieven voor deelname van de lijst aan de gemeenteraadsverkiezingen van 1982.

De open vraag die hierop betrekking had luidde als volgt:

"Groeperingen en personen kunnen om een groot aantal verschillende motieven aan de verkiezingen deelnernen. Het kan zijn dat de groepering als plaatselijke afdeling van een landelijke partij optreedt. Het kan echter ook gaan om het behartigen van belangen van boeren of werknemers, van een bepaalde wijk of dorp, of van bepaalde verenigingen. Ook is het mogelijk dat het gaat om tegenstellingen tussen personen of dat men het niet eens is met het beleid van de gemeente en daarom aan de verkiezing deelneemt. Mag ik u vragen: wat waren de motieven van uw grcepering orn aan de gemeenteraadsverkiezingen in 1982 deel te nemen?"

Om een indruk te geven van de antwoorden op deze vraag, zijn hieronder enkele reacties weergegeven.

"Het algemeen belang van de gemeente dienen. De burgers weten dat ik eerlijke politiek bedrijf, hetgeen mij stemmen oplever, zodat ik weer zeker ben van een plaatsje in de raad."

"Het algemeen belang van de gemeente dienen. De lijst heeft een grote variatie wat betreft de maatschappelijke en sociale status van de personen die op de lijst voorkomen."

"Vertegenwoordigen van de gemeenschap, maar eveneens van boeren en tuinders."

"Vooral traditionele overwegingen. De lijst vindt zijn wortels nog voor de oorlog in toen opererende lijsten. Oorspronkelijk waren er veel stemmen vanuit een bepaalde harmonie. Dit is verslapt met het optreden van een nieuwe lijst. Maar toch nog een deel van die traditionele kiezers overgehouden. Daamaast is het voor een groot deel boerenvertegenwoordiging."

"Om op progressieve wijze de belangen in de gemeenschap te behartigen. De gemeente is te conservatief. De plaatselijke politiek had alleen oog voor belangen van boer, winkelier en tuinder."

"Vertegenwoordiging van werknemers dat was het enige motief. Vertegenwoordiging van werknemers is er altijd geweest. Er zijn eerder aan de NKV/KAB gelieerde lijsten geweest, vandaar." "De wijk had meer aandacht nodig. Verder geen politieke items. Ik ben er puur als wijkvertegenwoordiger ingekomen."

"De lijst staat vooral voor het belang van dit dorp. Het andere dorp is groter en er zijn bovendien veel inwoners van buiten de gemeente komen wonen. Die mensen zijn meer partij-politiek gericht."

Uit de bovenstaande voorbeelden, blijkt dat het niet in alle gevallen duidelijk is om welk type lijst het gaat. Zoals werd verwacht, vallen sommige lijsten in twee categorieën tegelijk. Een aantal antwoorden is bovendien moeilijk te interpreteren, zoals bijvoorbeeld het frequent aangehaalde motief van de 'belangenbehartiging van de hele gemeenschap'. 
Tabel 4.1. Motieven van lokale lijsten voor deelname aan de gemeenteraadsverkiezingen van 1982 , naar verschillende categorieèn.

\begin{tabular}{lr}
\hline territoriaal & 14 \\
sociaal-economisch & 14 \\
cultureel & 2 \\
persoonsgebonden & 11 \\
vernieuwingsgezind & 14 \\
overig & 7 \\
Totaal & 62 \\
aantal respondenten & $(55)$ \\
\hline
\end{tabular}

Bron: Lijsttrekkersenquête, RL

In tabel 4.1 is een overzicht gegeven van de genoemde motieven, achteraf verdeeld over een zestal categorieën, waarvan de eerste vijf corresponderen met de eerder genoemde typen scheidslijnen. Een aantal antwoorden is in twee categorieën tegelijk ondergebracht.

De restcategorie betreft antwoorden waarin niet verwezen werd naar een bepaald groepsbelang, noch naar de persoon van de lijsttrekker, noch naar onvrede met het bestaande beleid of de bestaande lijsten. Het betreft antwoorden als "Belangenbehartiging voor alle inwoners."

Het betrekkelijk grote aantal 'territoriale' motieven is voor de Zuidlimburgse respondenten deels terug te voeren op de gemeentelijke herindeling. Bij de herindelingsverkiezingen hebben veel lokale lijsten deelgenomen die geheel voortkwamen uit opgeheven gemeenten. De voomaamste doelstelling van deze lijsten vormde het behartigen van de belangen van de eigen voormalige gemeente in het grotere verband van de nieuwe gemeente (Dittrich, 1983).

Bij de verwijzingen naar de behartiging van verenigings- en standenbelangen valt op dat de lijsttrekkers hier vaak spraken van het voortzetten van een bepaalde traditie. Het beeld van de case-studies dat dergelijke scheidslijnen in de loop der tijd door anderen zijn overschaduwd, vindt hierin enige bevestiging. Ook de omvang van de categorie vernieuwingsgezinde lijsten sluit aan bij de eerder beschreven ontwikkeling van lijsten die zich op een dergelijke wijze profileerden. De opkomst van deze categorie kan in verband gebracht worden met de massale introduktie van landelijke lijsten in 1982.

Uit het bovenstaande blijkt dat de Limburgse lokale lijsten een afspiegeling vormden van in de tijd wisselende tegenstellingen in de betreffende gemeenten. Bepaalde scheidslijnen verloren of wonnen aan belang, nieuwe scheidslijnen overvleugelden oude. Sommige lijsten vertoonden, ondanks het feit dat het conflict waaraan zij hun bestaansgrond ontleenden geen rol van betekenis meer speelt in de gemeenschap, een opmerkelijke mate van continuiteit. Verschillende plaatselijke groeperingen wisten 
Tabel 4.2. Politieke voorkeur van lijsttrekkers van lokale lijsten bij Tweede Kamerverkiezingen in 1982 en 1986.

\begin{tabular}{lrr}
\hline & 1982 & 1986 \\
\hline CDA & $40 \%$ & $47 \%$ \\
PvdA & $15 \%$ & $17 \%$ \\
VVD & $25 \%$ & $19 \%$ \\
D66 & $8 \%$ & $5 \%$ \\
PPR/PSP/CPN & $12 \%$ & $12 \%$ \\
& & \\
Totaal & $100 \%$ & $100 \%$ \\
& $(55)$ & $(55)$ \\
\hline
\end{tabular}

Bron: Lijsttrekkersenquête, RL

kennelijk flexibel in te spelen op de wijzigingen in de scheidslijnen. Dit leidt ertoe dat de lijsten over het algemeen niet eenduidig zijn te classificeren ${ }^{4}$.

\section{Politieke kleur lijsttrekkers}

Een ander resultaat dat uit de lijsttrekkersenquête naar voren is gekomen, vormt het feit dat de lijsttrekkers van lokale lijsten in 1982 niet langer beschouwd kunnen worden als behorend tot, of gelieerd aan de katholieke (of christen-democratische) politieke stroming. Hoewel lokale lijsten in Limburg tijdens de periode van verzuiling zeker niet te beschouwen waren als 'facties' (Sartori, 1976:73) binnen de Katholieke Volkspartij, kon van lokale politici wel aangenomen worden dat ze destijds in grote meerderheid deel uitmaakten van de katholieke zuil.

Een aanwijzing voor de nadien toegenomen politiek-ideologische pluriformiteit van lokale lijsten, wordt gevormd door de politieke voorkeuren van de lijsttrekkers daarvan bij Tweede Kamerverkiezingen. Deze voorkeuren zijn weergegeven in tabel 4.2.

Het CDA vormde de meest verkozen partij door lijsttrekkers van lokale lijsten. Toch had meer dan de helft van de respondenten in 1982 en in 1986 niet op deze partij gestemd. Overigens moet bedacht worden dat de betreffende lijsttrekkers waar het hun eigen opstelling in de lokale politiek betrof, gewoonlijk veel waarde hechtten aan een 'neutrale' positie ten opzichte van de verschillende politiek-ideologische stromingen. ( $\mathrm{Bij}$ de lijsttrekkersenquête bleek dit onder andere uit de in paragraaf 3.3 weergegeven antwoorden op de vraag waarom men niet met een landelijke lijst aan verkiezingen had deelgenomen.)

4 Dit is tevens de reden dat het niet verantwoord zou zijn om de hier gepresenteerde typologie in het vervolg van deze studie als onafhankelijke variabele te hanteren. 
Tabel 4.3. Mogelijkheid om lid te worden van politieke groeperingen naar type lijst.

\begin{tabular}{llll}
\hline & Lokaal & Landelijk & Totaal \\
\hline wel lidmaatschap & $55 \%$ & $100 \%$ & $74 \%$ \\
& $(30)$ & $(43)$ & $(73)$ \\
geen lidmaatschap & $45 \%$ & - & $26 \%$ \\
& $(25)$ & & $(25)$ \\
Totaal & $100 \%$ & $100 \%$ & $100 \%$ \\
& $(55)$ & $(43)$ & $(98)$ \\
\hline
\end{tabular}

$\mathrm{chi}^{2}=23,03 ;(p \leq 0,005)$

Bron: Lijsttrekkersenquête, RL

Tabel 4.4. Aanwezigheid van een bestuur van politieke groeperingen naar type lijst.

\begin{tabular}{llll}
\hline & Lokaal & Landelijk & Totaal \\
\hline wel bestuur & $42 \%$ & $100 \%$ & $67 \%$ \\
& $(23)$ & $(43)$ & $(66)$ \\
geen bestuut & $58 \%$ & - & $33 \%$ \\
& $(32)$ & & $(32)$ \\
Totaal & $100 \%$ & $100 \%$ & $100 \%$ \\
& $(55)$ & $(43)$ & $(98)$ \\
\hline
\end{tabular}

$\operatorname{chi}^{2}=33.71 ;(p \leq 0,005)$

Bron: Lijsttrekkersenquête, RL

Tabel 4.5. Aanwezigheid van een bestuur en mogelijkheid om lid te worden van lokale lijsten.

\begin{tabular}{llll}
\hline & wel & niet & Total \\
\hline wel lidmaatschap & $33 \%$ & $22 \%$ & $55 \%$ \\
& $(18)$ & $(12)$ & $(30)$ \\
geen lidmaatschap & $8 \%$ & $37 \%$ & $45 \%$ \\
& $(5)$ & $(20)$ & $(25)$ \\
Totaal & $41 \%$ & $59 \%$ & $100 \%$ \\
& $(23)$ & $(32)$ & $(55)$ \\
\hline
\end{tabular}

Bron: Lijsttrekkersenquête, RL 
Tabel 4.6. Aantal leden van politieke groeperingen kort voor de raadsverkiezingen van 1982, naar type lijst.

\begin{tabular}{llll}
\hline Aantal leden: & Lokaal & Landelijk & Totaal \\
\hline geen & $45 \%$ & - & $26 \%$ \\
& $(25)$ & & $(25)$ \\
$1-20$ & $33 \%$ & $12 \%$ & $23 \%$ \\
& $(18)$ & $(5)$ & $(23)$ \\
$21-50$ & $13 \%$ & $19 \%$ & $15 \%$ \\
$50+$ & $(7)$ & $(8)$ & $(15)$ \\
& $9 \%$ & $69 \%$ & $36 \%$ \\
\multirow{2}{*}{ Totaal } & $(5)$ & $(30)$ & $(35)$ \\
& & & \\
& $100 \%$ & $100 \%$ & $100 \%$ \\
\hline
\end{tabular}

$\mathrm{chi}^{2}=38,77 ;(\mathrm{p} \leq 0,005)$

Bron: Lijsttrekkersenquête, RL

\subsection{Organisatie van lokale en landelijke lijsten}

In deze paragraaf staat de vraag centraal in hoeverre de in Limburg deelnemende lokale politieke groeperingen qua organisatie lijken op de afdelingen van landelijke partijen die zich bij verkiezingen onder een landelijk partij-label presenteren ${ }^{5}$. Diairbij behandelen wij achtereenvolgens de aanwezigheid van een bestuur, de mogelijkheid om lid te worden, de omvang van de organisatie en het al of niet houden van ledenvergaderingen. Daarnaast gaan wij in op de mate van continuiteit van deze politieke groeperingen.

\section{Bestuur, leden en ledenvergaderingen}

Enkele onderdelen van de (mondelinge) lijsttrekkersenquête hadden betrekking op de organisatie van de lijst. Aan de lijsttrekkers werd onder andere gevraagd of men in 1982 lid kon worden van de betreffende politieke groepering en zo ja, hoeveel leden men had kort voor de verkiezingen van dat jaar. Vervolgens werd aan de respondenten gevraagd of de lijst ook een bestuur kende.

5 In plaats van groeperingen of lijsten zou men kunnen spreken van lokale versus landelijke partijen. Beide typen lijsten voldoen aan gangbare definities van het begrip partij zoals bijvoorbeeld die van Sartori:

"a party is any political group that presents at elections, and is capable of placing through elections, candidates for public office." (Sartori, 1976:64). Om spraakverwarring te voorkomen hanteren wij in deze studie echter (zoals eerder vermeld) de aanduidingen:

- lokale lijst of lokale politieke groepering;

- landelijke lijst of (plaatselijke) afdeling van een landelijke partij. 
Op grond van de enquête-resultaten kan gesteld worden dat achter een groot deel van de lokale lijsten geen organisatie stond, in de zin van een groepering met formeel lidmaatschap en een apart bestuur. De afdelingen van landelijke partijen in Limburg vormden daarentegen wel groeperingen met een voor politieke partijen gebruikelijke organisatie-structuur. De verschillen tussen beide typen lijsten zijn in hoge mate significant. In de tabelien 4.3 en 4.4 zijn de gegevens betreffende de mogelijkheid om lid te worden en de aanwezigheid van een bestuur weergegeven.

Een combinatie van zowel de mogelijkheid om lid te worden als de aanwezigheid van een bestuur, blijkt slechts bij achttien lokale lijsten (ongeveer een derde van het totaal) voor te komen. In tabel 4.5 is dit zichtbaar gemaakt.

Het begrip 'bestuur' is eenduidig. Dat geldt in mindere mate voor het lidmaatschap (vgl. Duverger, 1967:61.) Een lijsttrekker van een lokale lijst die organisatorisch gezien beperkt is tot een samenbundeling van kandidaten bij raadsverkiezingen, is wellicht geneigd deze kandidaten als de leden van de lijst te beschouwen. Gelet op de gebruikelijke omvang van de kandidatenlijst, wordt in dit onderzoek ervan uitgegaan dat een ledenaantal van meer dan twintig indicatief is voor het bestaan van formeel lidmaatschap. Bij de overige groeperingen is de kans groot dat de kandidaten op de lijst tegelijk als leden werden beschouwd. Een overzicht van het ledental van lokale en landelijke lijsten is in tabel 4.6 gegeven.

Slechts twaalf lokale lijsten telden meer dan twintig leden. Deze lijsten behoorden alle tot de eerder genoemde achttien lokale lijsten die zowel de mogelijkheid van lidmaatschap als de institutionalisering van een partijbestuur kenden.

De plaatselijke afdelingen van politieke partijen in de steekproef hadden bijna allemaal meer dan twintig, de meeste zelfs meer dan vijftig leden. De uitzonderingen waren afdelingen van de PvdA (Helden en Beesel), D66 (Arcen en Velden, Brunssum), en de VVD (Margraten).

Bij een ledental van meer dan twintig kan verondersteld worden dat er naast fractieen bestuursvergaderingen ook regelmatig bijeenkomsten voor leden worden gehouden. Bij de plaatselijke partij-afdelingen was dat, op één uitzondering na, het geval. Van de twaalf in aanmerking komende lokale lijsten hadden slechts twee geen ledenvergaderingen in de periode 1982-1986 gehouden.

Uiteindelijk blijven er dus tien (van de vijfenvijftig) lokale lijsten over, die qua ledental en organisatiestructuur overeenkomen met de organisatie-structuur die wij bij de plaatselijke afdelingen van de landelijke politieke partijen aantreffen.

De bovenstaande gegevens hebben, zoals vermeld, betrekking op lijsten die aan de raadsverkiezingen van 1982 in vijftien Limburgse gemeenten deelnamen. Uit enkele case-studies ontstaat de indruk dat lokale lijsten in de periode dat landelijke partijen nog niet deelnamen aan gemeenteraadsverkiezingen in nog mindere mate waren georganiseerd. Men kan veronderstellen dat de vorming van lijsten met een organisatiemodel dat lijkt op deze partijen, onderdeel uitmaakt van het veranderingsproces ten gevolge van de nationalisering van de Limburgse lokale politiek. Een verbreding van het organisatorisch draagvlak door middel van het instellen van een bestuur en het werven van leden, zou kunnen voortkomen uit het streven om de concurrentiepositie ten opzichte van de beter georganiseerde landelijke partij-afdelingen te versterken. In 
dat geval zouden wij dergelijke lokale lijsten vooral verwachten in gemeenten waarin tevens landelijke partijen aan gemeenteraadsverkiezingen deelnamen.

Deze veronderstelling wordt door de gegevens van de enquête bevestigd. Van de tien lokale groeperingen waarvan wij eerder hebben geconstateerd dat zij qua organisatie-structuur overeenkwamen met de plaatselijke afdelingen van politieke partijen, traden er negen op in gemeenten waar minstens twee lijsten van grote landelijke partijen aan de verkiezingen deelnamen.

\section{Continuiteit}

In het vorige hoofdstuk is een overzicht gegeven van de nieuwe en verdwijnende lokale lijsten bij de verkiezingen van 1986 en 1990. De lijsttrekkersenquête, gericht op deelnemers aan de raadsverkiezingen van 1982, levert daarnaast gegevens op, met behulp waarvan de opvallend geringe mate van continuitteit van lokale lijsten nader geanalyseerd kan worden. Het betreft onder andere het aantal jaren dat de lijsten reeds actief zijn en de redenen voor lijsttrekkers om van lijst te veranderen. Deze door de lijsttrekkers opgegeven motieven voor lijstwisselingen geven inzicht in de aard van de organisatie van veel lokale politieke groeperingen.

Dat slechts weinig lokale lijsten in staat zijn geweest om meerdere decennia actief te blijven, wordt bevestigd door de oprichtingsdata van de lijsten in de steekproef, zoals die zijn opgegeven door de lijsttrekkers.

Van de vijfenvijftig onderzochte lokale lijsten die in 1982 in de steekproefgemeenten aan de verkiezingen deelnamen, deden er tweeëndertig in dat jaar voor het eerst mee. Slechts een zestal lokale lijsten was al vóór 1970 actief; de overige zeventien lijsten werden in de jaren zeventig geformeerd. De lijsttrekkers zelf hadden daarentegen veelal een langere politieke geschiedenis dan de lijst waar ze in 1982 voor uitkwamen. Vierenveertig van de vijfenvijftig lijsttrekkers van lokale lijsten waren al voor 1982 in de gemeenteraad verkozen, terwijl daamaast vier respondenten eerder zonder resultaat aan verkiezingen hadden deelgenomen.

Om na te gaan hoe vaak lijstwisselingen zijn voorgekomen, is aan de in totaal tachtig respondenten die eerder kandidaat waren geweest de vraag voorgelegd of zij bij deelneming aan verkiezingen voor 1982 ook wel eens met een andere dan hun huidige lijst waren uitgekomen. De antwoorden zijn weergegeven in tabel 4.7.a.

Lijstwisselaars kwamen zowel bij lokale als bij landelijke lijsten frequent voor. De verschillen tussen beide typen lijsten zijn niet significant. Een nadere uitsplitsing van de respondenten van landelijke lijsten naar de diverse partijen laat wel duidelijke verschillen per partij op dit punt zien ${ }^{6}$. Dit blijkt uit tabel 4.7.b.

In het vorige hoofdstuk is reeds gewezen op de veelvuldige overname van lokale lijsten door met name het CDA in 1982. Dit is in tabel 4.7.b terug te vinden. In zeven van de acht gevallen waarin CDA-respondenten meldden eerder met een lokale lijst te zijn uitgekomen, betrof het CDA-lijsten die in 1982 voor het eerst aan verkiezingen

6 De celfrequenties zijn echter te gering om de chi ${ }^{2}$-toets te hanteren. 
Tabel 4.7.a. Aantal lijsttrekkers dat van lijst veranderd is, naar type lijst.

\begin{tabular}{llll}
\hline & Lokaal & Landelijk & Totaal \\
\hline zelfde lijst & $31 \%$ & $44 \%$ & $36 \%$ \\
andere lijst & $(15)$ & $(14)$ & $(29)$ \\
& $69 \%$ & $56 \%$ & $64 \%$ \\
Totaal & $(33)$ & $(18)$ & $(51)$ \\
& $100 \%$ & $100 \%$ & $100 \%$ \\
\hline
\end{tabular}

chi $^{2}=1,30$; niet sign.

Bron: Lijsttrekkersenquête, RL

Tabel 4.7.b. Aantal lijsttrekkers van landelijke lijsten dat van lijst veranderd is, naar partij.

\begin{tabular}{llllll}
\hline & CDA & PvdA & VVD & Klein Links & Totaal \\
\hline zelfde lijst & 1 & 4 & 4 & 5 & 14 \\
andere lijst & 8 & 4 & 2 & 4 & 18 \\
Totaal & 9 & 8 & 6 & 9 & 32 \\
\hline
\end{tabular}

Bron: Lijsturekkersenquête, RL

deelnamen in de betreffende gemeenten. De enige uitzondering betrof een respondent die eerder lijsttrekker was geweest van een ARP/CHU-lijst.

De beide lijstwisselaars van de VVD waren eveneens voorheen (in 1974, respectievelijk 1978) kandidaat geweest op een lokale lijst. Een aantal lijsttrekkers van de PvdA en kleinere linkse partijen had voorheen aan verkiezingen deelgenomen met combinaties viun linkse partijen, die in 1982 niet meer in dezelfde samenstelling bestonden. Ook waren er twee overstappen van de ene landelijke partij naar de andere; één van de PPR naur D66 en cén van de PvdA naar PPR/PSP. Tenslotte waren er drie respondenten die bij eerdere verkiezingen op een lokale lijst hadden gestaan en in 1982 lijsttrekker waren geworden van een in dat jaar voor het eerst in hun gemeente optredende PvdA-, PPR-, respectievelijk PPR/PSP-lijst. Slechts één respondent van een lokale lijst gaf aan eerder met een landelijke lijst (PvdA/PSP) aan verkiezingen te hebben deelgenomen.

De grootste categorie lijstwisselaars (47 van de 80 ) betreft dus personen die van de ene lokale lijst naar een andere lokale lijst overstappen. Dat de motieven voor dit soort lijstwisselingen in een groot aantal gevallen een uitgesproken persoonsgebonden karakter hebben, wordt door het volgende overzicht van enkele typerende voorbeelden geillustreerd. 
"De lijst is ontbonden in verband met afhaken van de lijsttrekker."

"De reden was een breuk tussen dhr. X en mijzelf in verband met de wethoudersverkiezingen."

"De lijsttrekker zelf is gestorven. Over het lijsttrekkerschap werden de overige twee kandidaten het niet eens."

"Wij zijn vriendschappelijk uit elkaar gegaan, want wij beiden wilden wethouder worden. Daarom ben ik met een aparte lijst gekomen."

"Gebrek aan visie van de lijst en ik stond niet hoog genoeg. Daarom ben ik alleen verder gegaan." "Vanwege onenigheid binnen de fractie die bestond uit persoonlijke en politieke punten."

"Ik had meer kans op een verkiesbare plaats op een andere lijst."

"De lijsttrekker is gestopt. Toen ben ik met een andere lijst begonnen."

Uit deze antwoorden spreekt een tamelijk pragmatische houding van de respondenten ten opzichte van de betreffende lijsten. Het gevolg is dat lijsttrekkers hun lijsten regelmatig (politiek gezien) overleefden terwijl de omgekeerde situatie zeldzaam was.

\section{c. Samenvatting}

Qua organisatiestructuur komt uit de lijsttrekkersenquête een duidelijke tegenstelling naar voren tussen plaatselijke afdelingen van landelijke partijen en de meeste lokale politieke groeperingen. De organisatie van lokale lijsten doet sterk denken an het door Duverger geîntroduceerde begrip 'caucus'. Deze 'caucus' werd door hem als volgt gedefinieerd:

"The first characteristic of the caucus is its limited nature. It consists of a small number of members, and seeks no expansion. It does not indulge in any propaganda with a view to extending its recruitment. Moreover, it does not really admit members...; membership is achieved only by a kind of tacit co-option or by formal nomination.... Moreover the activity of the caucus is seasonal: it reaches its peak at election times and is considerably reduced in the intervals between the ballots. In short the caucus is semi-permanent by nature." (Duverger, 1967:18)

Minder dan een vijfde van de lokale lijsten in de steekproef kenden in het begin van de jaren tachtig een bestuur, een ledental boven de twintig en regelmatige ledenvergaderingen. De geringe mate van continuïteit van lokale lijsten bleek onder andere uit het feit dat een minderheid van de in 1982 deelnemende lijsten ook bij eerdere verkiezingen had deelgenomen.

Uit de veelvuldig voorkomende lijstwisselingen en de door respondenten opgegeven redenen daartoe valt af te leiden dat de lokale lijst voor de meer ambitieuze kandidaten primair een middel vormde om verkozen te worden. Zodra een bestaande lijst wat dat betreft niet meer functioneel werd geacht, stapte men over naar een andere lijst of richtte men zelf een nieuwe lijst op. Een poging tot institutionalisering van de lijst bleef gewoonlijk achterwege.

Typerend voor plaatselijke organisaties van landelijke partijen is daarentegen een streven om het ledental te vergroten en om ook tussen verkiezingen in activiteiten te ontplooien, om zodoende de continuïteit van de organisatie te waarborgen en minder afhankelijk te zijn van de persoon van de lijsttrekker. De vorming van een bestuur, 
ledenwerving en regelmatige bijeenkomsten van de leden zijn daartoe noodzakelijk (vgl. Duffhues, 1988:7). Het voortbestaan en de verdere uitbouw van deze politieke organisatie worden op die manier doelen op zich.

\subsection{Functioneren van lokale en landelijke lijsten}

De wellicht meest wezenlijke functie van politieke partijen vormt het opstellen van kandidatenlijsten voor verkiezingen, (vgl. Epstein, 1975:230 en 257). Daamaast kan als een tweede belangrijke functie van partijen worden genoemd, het kanaliseren en articuleren van opvattingen over het te voeren beleid, (Sartori, 1976:28; Thomassen, 1981:166; Zielonka-Goei, 1989:12). Voor Lasswell en Kaplan zijn deze beide functies dermate kenmerkend dat zij hun definitie van partijen daarop toespitsen:

"A party (political) is a group formulating comprehensive issues and submitting candidates in elections." (Geciteerd in: Sartori, 1976:62) ${ }^{7}$

Deze formulering van 'issues' vindt in de regel plaats in een verkiezingsprogramma. In deze paragraaf worden lokale en landelijke lijsten vergeleken op het punt van de besluitvorming rond kandidatenlijsten en de afspraken die worden gemaakt ten aanzien van de gevolgen van voorkeurstemmen voor de lijstvolgorde. Daarnaast bespreken wij de omvang van verkiezingsprogramma's als indicator voor de wijze waarop de tweede functie wordt uitgeoefend.

\section{Kandidaatstelling}

Bij de mondelinge lijsttrekkersenquête is gevraagd op welke wijze het besluit over de volgorde van kandidaten op de kandidatenlijst bij de verkiezingen van 1982 tot stand is gekomen binnen de eigen groepering. Indien geen spontaan antwoord volgde is aan de respondenten een aantal mogelijkheden voorgelegd, te weten: onderlinge afspraken; groslijststemming; door lijsttrekker bepaald; voordracht door commissie of bestuur en loting.

In tabel 4.8 is de respons op deze vraag weergegeven. Aan de hand van de antwoorden zijn de hierboven genoemde categorieën als volgt samengevoegd. Na de eerste categorie, onderlinge afspraken, is de categorie stemming door leden opgevoerd. Daaronder wordt een procedure verstaan waarbij veelal het bestuur, in enkele gevallen geadviseerd door een aparte commissie, een kandidatenlijst ter stemming aan de leden(vergadering) voorlegt. De overige mogelijkheden zijn in een restcategorie samengevoegd.

Uit deze gegevens blijkt dat bij de meeste lokale lijsten in de steekproef een informele besluitvormingsmethode gehanteerd werd. Naast onderlinge afspraken kunnen daartoe ook de bij de categorie 'overige' ondergebrachte methoden van loting (vijf keer) en bepaling door de lijsttrekker (drie keer) ondergebracht worden. Alle elf lokale

7 Overigens delen wij de mening van Sartori dat het opstellen van verkiezingsprogramma's geen onderdeel zou moeten uitmaken van de definitie van politieke partijen (Sartori, 1976:62). 
Tabel 4.8. Besluitvormingsmethode inzake de kandidatenlijst, naar type lijst.

\begin{tabular}{llll}
\hline & Lokaal & Landelijk & Totaal \\
\hline onderlinge afspraken & $62 \%$ & $10 \%$ & $39 \%$ \\
stemming leden & $(34)$ & $(4)$ & $(38)$ \\
overige & $20 \%$ & $88 \%$ & $50 \%$ \\
& $(11)$ & $(38)$ & $(49)$ \\
Totaal & $18 \%$ & $2 \%$ & $11 \%$ \\
& $(10)$ & $(1)$ & $(11)$ \\
& $100 \%$ & $100 \%$ & $100 \%$ \\
\hline
\end{tabular}

$\mathrm{chi}^{2}=46,26 ;(\mathrm{p} \leq 0,005)$

Bron: Lijsttrekkersenquête, $\mathrm{RL}$

lijsten die de kandidatenlijst door stemming van de leden samenstelden, behoorden tot de categorie van achttien van dit type lijsten die zowel een bestuur als lidmaatschap kenden.

Bij plaatselijke afdelingen van landelijke partijen, daarentegen, past het bij het gebruikelijke organisatiemodel dat er een formele stemming van de leden plaatsvindt, zelfs indien het ledental gering is. Onderlinge afspraken kwamen slechts voor bij twee lijsten van het CDA, één van de PvdA en één van de VVD.

Een ander opvallend verschil tussen lokale en landelijke lijsten doet zich voor met betrekking tot de wijze waarop men persoonlijke voorkeurstemmen laat meetellen bij de invulling van de na verkiezingen aan de betreffende lijst toegewezen raadszetels.

De Kieswet regelt de manier waarop moet worden vastgesteld welke kandidaten van een lijst verkozen zijn. Primair bepalend daarvoor is de volgorde die op de lijst is aangegeven. De aan een lijst toegewezen zetels worden ingevuld overeenkomstig die volgorde (art. P 17 Kieswet). Hiervan wordt echter afgeweken indien eén van de kandidaten een aantal voorkeurstemmen behaalt dat meer bedraagt dan de helft van de kiesdeler. Dergelijke personen worden direkt verkozen verklaard, voor zover aan de lijst voldoende zetels zijn toegewezen (art. P 15 Kieswet).

Aangezien het aantal benodigde voorkeurstemmen om los van de lijstvolgorde ('met voorkeur') verkozen te worden tamelijk hoog is, heeft de door de partij zelf vastgestelde volgorde van kandidaten dankzij deze regeling een bijzonder zwaar gewicht. Dat gewicht kan alleen verminderen indien de kandidaten onderling afspreken dat zij een van de regeling van de Kieswet afwijkende manier van invulling van de toegewezen zetels zullen hanteren.

Een voorbeeld van een dergelijke (overigens niet rechtens afdwingbare) afspraak, is de regel dat de volgorde van de kandidaten na de verkiezingen opnieuw wordt bepaald aan de hand van het op hen persoonlijk uitgebrachte aantal stemmen. De zetels die de lijst mag bezetten, worden vervolgens ingenomen conform die laatste volgorde. Dat kan inhouden dat personen die door het stembureau verkozen zijn verklaard, hun 
Tabel 4.9. Mate waarin door kandidaten afspraken zijn gemaakt omtrent de invulling van toegewezen zetels, naar type lijst.

\begin{tabular}{llll}
\hline & Lokaal & Landelijk & Totaal \\
\hline wel afspraak & $62 \%$ & $9 \%$ & $39 \%$ \\
& $(33)$ & $(4)$ & $(37)$ \\
geen afspraak & $38 \%$ & $91 \%$ & $61 \%$ \\
& $(20)$ & $(39)$ & $(59)$ \\
Totaal & $100 \%$ & $100 \%$ & $100 \%$ \\
geen antwoord & $(53)$ & $(43)$ & $(96)$ \\
& 2 & - & 2 \\
\hline
\end{tabular}

$\mathrm{chii}^{2}=28.11 ;(\mathrm{p} \leq 0,005)$

Bron: Lijsturekkersenquête, RL

zetel afstaan ten gunste van lager op de lijst geplaatste kandidaten, indien deze meer voorkeurstemmen hebben behaald. In tabel 4.9 is aangegeven bij hoeveel lijsten in 1982 afspraken tussen de kandidaten bestonden, om af te wijken van de regeling van de Kieswet in de hierboven bedoelde zin.

De kandidaten van de landelijke lijsten in de steekproefgemeenten stelden zich, op een enkele uitzondering na, onder het regime van de Kieswet. (De uitzonderingen betroffen twee CDA-lijsten, één lijst van de PvdA en één van klein links.) Bij een meerderheid van de lokale lijsten, daarentegen, werd door de kandidaten afgesproken dat het door iedere kandidaat afzonderlijk behaalde aantal voorkeurstemmen bepalend zou zijn voor de uiteindelijke volgorde van de kandidaten en daarmee voor de invulling van de zetels die de lijst zou verkrijgen.

De aantallen door de diverse kandidaten behaalde stemmen speelden overigens bij diverse lokale groeperingen tevens een belangrijke rol bij de vaststelling van de volgorde op de kandidatenlijst voor volgende verkiezingen. Dit bleek uit de respons op de hiervoor behandelde vraag naar de wijze van vaststelling van deze volgorde. Verschillende keren meldden de respondenten dat de vorige verkiezingsuitslag een leidraad vormde bij het maken van onderlinge afspraken over deze volgorde.

Dat het bestaan van dit soort afspraken door veel lokale lijsten werd beschouwd als een belangrijk onderdeel van de eigen profilering, spreekt uit het feit dat deze afspraken in bijna alle gevallen uitdrukkelijk in het eigen verkiezingsmateriaal vermeld werden.

\section{Verkiezingsprogramma}

Hoewel de gevoerde procedure inzake het vaststellen van een verkiezingsprogramma bij de verschillende afdelingen van politieke partijen niet geheel gelijk is, ziet de gang van zaken er in grote lijnen gewoonlijk als volgt uit. Door het bestuur, al dan niet bijgestaan door een aparte programcommissie en in samenspraak met de fractie, wordt een concept-programma opgesteld. Daarbij wordt gebruik gemaakt van een model- 
programma dat door de moeder-partij is geleverd. De ledenvergadering stelt het verkiezingsprogramma uiteindelijk (na eventuele amendering) vast. Plaatselijke afde-lingen volgen ook op dit punt het voorbeeld van de landelijke partij waar zij deel van uitmaken ${ }^{8}$.

Zoals wij eerder hebben gezien misten bijna alle lokale lijsten in de steekproef een organisatiestructuur zoals die voor de bovenstaande procedure is vereist. Bovendien is uit de eerste paragraaf van dit hoofdstuk, bij de bespreking van een typologie van lokale lijsten, naar voren gekomen dat veel van deze groeperingen niet primair georiënteerd zijn op de vaststelling van politiek-inhoudelijke standpunten, laat staan op politieke ideologieën als grondslag voor een programmatische uitwerking.

Met behulp van de lijsttrekkersenquête is onderzocht in welke mate de in de steekproefgemeenten opererende lijsten in 1982 over een programma beschikten. Daamaast is geïnventariseerd hoe omvangrijk de verschillende verkiezingsprogramma's waren ${ }^{9}$. Deze gegevens zijn samengevat in tabel 4.10.

Tabel 4.10. Aanwezigheid en omvang van verkiezingsprogramma's naar type lijst.

\begin{tabular}{llll}
\hline & Lokaal & Landelijk & Totaal \\
\hline geen progranma & $16 \%$ & - & $9 \%$ \\
aantal pagina's: & $(8)$ & & $(8)$ \\
$1-2$ & $48 \%$ & $8 \%$ & $31 \%$ \\
$3-9$ & $(24)$ & $(3)$ & $(27)$ \\
$10+$ & $24 \%$ & $24 \%$ & $24 \%$ \\
& $(12)$ & $(9)$ & $(21)$ \\
Totaal & $12 \%$ & $68 \%$ & $36 \%$ \\
& $(6)$ & $(26)$ & $(32)$ \\
geen antwoord & $100 \%$ & $100 \%$ & $100 \%$ \\
\hline
\end{tabular}

$\mathrm{chi}^{2}=36,43 ;(\mathrm{p} \leq 0,005)$

Bron: Lijsttrekkersenquête, RL

8 De procedures rond de totstandkoming van landelijke verkiezingsprogramma's zijn voor een viertal partijen in kaart gebracht in: Zielonka-Goei, 1989: 164 e.v.

9 Waar het verkiezingsprogramma voorhanden was, is door de interviewer het aantal pagina's geteld, omgerekend naar A-4-formaat. Lege ruimtes zijn daarbij niet meegerekend. In de overige gevallen betreft het een opgave van de respondent. Om deze opgaven van respondenten mee te kunnen tellen is afgezien van telling van het aantal woorden, een op zich betrouwbaarder vergelijkingsmethode. Gelet op de bij de telling van het aantal pagina's reeds naar voren komende evidente tweedeling tussen lokale en landelijke lijsten op dit punt, kan het daardoor opgetreden informatieverlies als minder emstig worden beschouwd. 
Tabel 4.11. Lokale lijsten naar omvang verkiezingsprogramma's en organisatievorm.

\begin{tabular}{llll}
\hline & \multicolumn{2}{l}{ Organisatievorm: } & \\
\cline { 2 - 3 } & A & T & Totaal \\
\hline geen programma & - & $23 \%$ & $16 \%$ \\
Aantal pagina's: & & $(8)$ & $(8)$ \\
$1-2$ & $27 \%$ & $57 \%$ & $48 \%$ \\
$3-9$ & $(4)$ & $(20)$ & $(24)$ \\
$10+$ & $46 \%$ & $14 \%$ & $24 \%$ \\
& $(7)$ & $(5)$ & $(12)$ \\
Total & $27 \%$ & $6 \%$ & $12 \%$ \\
geen antwoord & $(4)$ & $(2)$ & $(6)$ \\
\hline
\end{tabular}

A = Lijsten met bestuur en lidmaatschap; B = Lijsten zonder bestuur of lijsten zonder lidmaatschap of lijsten zonder beide.

Bron: Lijsttrekkersenquête, RL

Het grootste deel van de lokale lijsten bezat in 1982 geen uitgewerkt verkiezingsprogramma. Gewoonlijk waren er wel enkele beleidspunten geformuleerd in de vorm van een verkiezingspamflet. De landelijke lijsten beschikten daarentegen (zoals verwacht) in het algemeen over meer uitgebreide programma's. Deze lijsten hadden echter het voordeel dat zij gebruik konden maken van de modelprogramma's, waaruit algemene beleidsanalyses en doelstellingen overgenomen konden worden, zodat betrekkelijk gemakkelijk een omvangrijk verkiezingsprogramma ontstond.

In tabel 4.11 is de omvang van verkiezingsprogramma's gerelateerd aan de gegevens betreffende de organisatie-structuur van lokale politieke groeperingen.

Uit deze cijfers blijkt dat lokale lijsten die beschikten over een bestuur en leden, over het algemeen meer omvangrijke verkiezingsprogramma's produceerden, terwijl lijsten die niet op een dergelijke wijze waren georganiseerd veelal geen of slechts een enkele of twee pagina's omvattend pamflet uitbrachten.

\section{c. Samenvatting}

In deze paragraaf is het functioneren van lokale lijsten voor wat betreft twee fundamentele functies van politieke partijen in een vertegenwoordigende democratie vergeleken met het functioneren van plaatselijke afdelingen van landelijke partijen. De verschillen die tussen beide categorieën lijsten eerder werden gevonden op het vlak van de organisatie, blijken ook ten aanzien van het functioneren zeer groot. 
Ten gevolge van de geringere organisatiegraad van de meeste lokale politieke groeperingen werd de volgorde van de kandidatenlijst gewoonlijk in onderlinge overeenstemming door de kandidaten zelf geregeld. Bij landelijke lijsten was het daarentegen gebruikelijk om de ledenvergadering over de volgorde te laten stemmen.

In samenhang hiermee woog de voor de verkiezingen vastgestelde volgorde van kandidaten op de lijst bij lokale groeperingen minder zwaar op het moment dat de aan de lijst toegewezen zetels werden ingevuld. Het absolute aantal stemmen dat elke kandidaat afzonderlijk had verkregen speelde daarbij een doorslaggevende rol. De landelijke lijsten volgden vrijwel zonder uitzondering de regeling die de Kieswet aangeeft. Alleen wanneer het aantal op een kandidaat uitgebrachte stemmen meer bedraagt dan de halve kiesdeler, wordt in dat geval de van te voren vastgestelde lijstvolgorde doorbroken.

Als tweede functie van politieke partijen is het opstellen van verkiezingsprogramma's onderzocht. Uit dit onderzoek komt naar voren dat de lokale lijsten minder uitgebreide verkiezingsprogramma's opstelden. Deze lijsten volstonden veelal met een korte opsomming van een aantal voor hen belangrijke thema's.

\subsection{Recente en te verwachten ontwikkelingen ten aanzien van de organisatie en het functioneren van de lijsten}

In de jaren tachtig is bij een aantal lokale politieke groeperingen een ontwikkeling op gang gekomen in de richting van organisatorische institutionalisering en meer beleidsinhoudelijke profilering. Dit proces is ook wel aangeduid als professionalisering van lokale lijsten (bv. Welten, 1987). Om een aantal redenen is te verwachten dat het beeld van lokale lijsten dat uit de op de periode 1982-1986 betrekking hebbende lijsttrekkersenquête naar voren komt, aan verandering onderhevig is.

Een eerste belangrijke impuls voor een professionalisering van lokale lijsten werd gevormd door het proces van gemeentelijke herindeling; in Zuid-Limburg in 1981 en in Midden-Limburg in 1990. Deze gemeentelijke herindeling bracht een schaalvergroting met zich mee die er onder andere toe leidde dat er meer stemmen nodig zijn om een raadszetel te bemachtigen.

In de voormalige gemeente Sint-Geertruid, bijvoorbeeld, lag de kiesdeler in 1978 op 129 stemmen. Men hoefde dan ook niet meer dan 97 stemmen ( 75 procent van de kiesdeler) te vergaren om in aanmerking te komen voor een restzetel. In deze situatie kon een lijst die rond enkele stemmentrekkers was opgebouwd vrij snel succes hebben. In de gemeente Margraten, waarin Sint-Geertruid bij de herindeling is opgegaan, lag de kiesdeler bij de herindelingsverkiezingen in 1981 op 536 stemmen.

Ook het besef dat een eenmansfractie in de gemeenteraad van een grotere gemeente minder invloed heeft dan in de veelal uit zeven leden bestaande raden van opgeheven gemeenten, zal bijgedragen hebben aan de schaalvergroting van lokale lijsten. In het vorige hoofdstuk is de afname van het aantal deelnemende lokale lijsten geanalyseerd. Daarbij kwam onder andere naar voren dat met name het aantal kleine lijsten sterk is gedaald. Het is aannemelijk dat bij de schaalvergroting van lokale politieke groeperin- 
gen, onder andere als uitvloeisel van samenwerking tussen verschillende lokale lijsten, eerder behoefte ontstond aan een organisatievorm zoals die bij partij-afdelingen gebruikelijk was en is.

Een tweede (al eerder genoemde) factor vormt de toegenomen concurrentie van landelijke lijsten. Dit versterkte de noodzaak voor lokale lijsten om continuïteit en vergroting van de basis van de organisatie als belangrijke organisatiedoelen te aanvaarden. Anders dan in het verleden zagen de lokale lijsten in toenemende mate betrekkelijk succesvolle en beter georganiseerde concurrenten tegenover zich, die klaar stonden om de gaten op de electorale markt op te vulien die opgeheven lokale lijsten achter zich lieten. Het proces van nationalisering leek alleen nog te keren door geprofessionaliseerde lokale lijsten ${ }^{10}$.

Een derde aanleiding voor professionalisering leverde een wijziging in de Kieswet op, die bij de verkiezingen van 1990 voor het eerst werd toegepast. Vanaf dat jaar is het niet langer mogelijk om registratie van een lijstnaam te verkrijgen, indien de lijst niet het karakter van een vereniging met volledige rechtsbevoegdheid heeft (art. G3 Kieswet). Dit impliceert dat een lijst - voor zover men geïnteresseerd is in vermelding van de naam van de groepering op onder andere het stembiljet - voortaan (althans formeel) een bestuur en de mogelijkheid van lidmaatschap moet kennen.Van de in totaal 142 in 1990 aan de gemeenteraadsverkiezingen in Limburg deelnemende lokale lijsten hebben er 111 (of 78 procent) zich laten registreren "I.

Een afname van de bij lokale lijsten veelvuldig voorkomende afspraken op het punt van de omgang met voorkeurstemmen, is niet te verwachten. Veel lijsttrekkers beschouwen dergelijke afspraken juist als een groot voordeel ten opzichte van landelijke partijen. Naar de kiezers toe wordt gesuggereerd dat lokale lijsten dankzij dit soort afspraken meer gewicht verlenen aan de door middel van voorkeurstemmen uitgedrukte voorkeur voor bepaalde personen. Dit werd en wordt als een belangrijk onderdeel van de profilering ten opzichte van landelijke lijsten beschouwd.

Met de eerder gesignaleerde wijzigingen in de organisatie van lokale lijsten en ook de veranderde motivatie en doelstellingen van dit type lijsten, kan tenslotte verondersteld worden dat verkiezingsprogramma's van lokale lijsten omvangrijker worden en ook intern een belangrijker rol zullen gaan spelen. De lokale lijsten worden, dankzij de concurrentie met landelijke lijsten, meer dan in het verleden uitgedaagd tot beleidsinhoudelijke stellingnames en lijken ook eerder bereid om op die uitdaging een antwoord te formuleren. Bij dit onderdeel verwachten wij dan ook, evenals op het punt van de organisatie, een toenemende convergentie tussen lokale en landelijke lijsten.

10 Het navolgen van kenmerken van een concurrent is overigens een tendens, voortkomend uit een ook op andere terreinen te constateren mechanisine, dat door Girard aangeduid is als 'rivalité mimétique' (Girard, 1978).

11 Volgens opgaaf van de gemeenten. 


\section{Hoofdstuk 5}

\section{De band tussen kiezers en politici}

\subsection{Inleiding}

Bij verkiezingen wordt een zekere band manifest tussen kiezers en politici c.q. hun politieke organisaties. Wat de kiezer door middel van het uitbrengen van zijn stem precies uitdrukt is moeilijk te achterhalen. Harrop en Miller (1987) onderscheiden aan de hand van een literatuuroverzicht drie globale benaderingen. In het zogenaamde partij-identificatie model wordt kiezersgedrag met name geïnterpreteerd vanuit het idee dat de meeste kiezers een tamelijk stabiele band ontwikkelen met een bepaalde politieke partij. Deze identificatie vindt veelal op jonge leeftijd plaats als resultaat van socialisatieprocessen.

Een tweede, vanuit de inzichten van de economische wetenschap ontwikkelde benadering, is het rationele keuze model. De bij verkiezingen zichthailr wordende band tussen kiezer en partij of kandidaat wordt als het resultaat van een bewuste en instrumentele keuze gezien. Deze keuze komt tot stand op basis van een vergelijking tussen de eigen beleidsstandpunten met die van de verschillende partijen of kandidaten. De kiezer hanteert zijn stem als een instrument om het te voeren beleid in de door hem gewenste richting te buigen.

In de sociologische benadering, tenslotte, wordt het verband tussen bepaaldle achtergrondvariabelen van de kiezers zoals leeftijd en klasse of gebondenheid aan groepen zoals bepaalde verenigingen, in verband gebracht met het kiesgedrag. Het behoren tot een bepaalde categorie of groep indiceert een daarbij passend stemgedrag.

In de Limburgse lokale politiek zijn politieke partijen met een landelijke naam lange tijd vrijwel afwezig geweest, terwijl de lokale lijsten in de regel niet als coherente politieke groeperingen met een eigen profiel aan de kiezers appelleerden. Bij verkiezingen lichtte eerder de binding tussen de kiezer en een kandidaat, dan tussen de kiezer en een partij op. Het partij-identificatie model heeft in die context slechts een beperkte waarde. Op basis van de in hoofdstuk 3 gemaakte indeling in typen lokale lijsten kan daarentegen verwacht worden dat de politieke binding aan bepaalde kandidaten als logische consequentie van sociologische bindingen in de Limburgse gemeentepolitiek wel een belangrijke rol heeft gespeeld. Daarbij is het denkbaar dat ook elementen die in de rationele keuze benadering benadrukt worden, bij de afweging van individuele kiezers een rol hebben gespeeld. Een bijzondere vorm van een instrumenteel type 
binding die vanuit dit perspectief gë̈nterpreteerd kan worden is het cliëntelisme. Daarbij verleent de kiezer een stem min of meer in ruil voor ontvangen dienstverlening van de politicus. Op dit begrip gaan wij aan het eind van het hoofdstuk nader in.

In de jaren tachtig deden de landelijke partijen hun intrede. Lokale lijsten ontwikkelden zich daarnaast tot op continuïteit gerichte lokale politieke groeperingen met een eigen programmatische basis. Het ligt voor de hand om te veronderstellen dat de band tussen kiezers en gekozenen door deze ontwikkelingen een minder persoonlijk karakter kreeg. Ook werd hierdoor een bovenlokaal element geüntroduceerd; kiezers konden voortaan bij gemeenteraadsverkiezingen mede hun nationale voorkeuren of partijidentificatie tot uitdrukking brengen.

In dit hoofdstuk willen wij nagaan wat de achtergronden zijn van de band tussen kiezers en politici in de Limburgse lokale politiek. Daarbij gaan wij met name na of deze band een meer persoonlijk dan wel onpersoonlijk karakter beeft en in welke mate er sprake is van instrumentele motieven van de kant van de kiezers. Het materiaal dat wij daartoe ter beschikking hebben heeft betrekking op de jaren tachtig. Daardoor is een vergelijking mogelijk tussen lokale en landelijke lijsten op dit punt.

Als eerste indicatie voor de mate waarin de band tussen kiezers en politici in Limburg een persoonlijk karakter heeft, kijken wij naar de percentages uitgebrachte voorkeurstemmen bij de gemeenteraadsverkiezingen vanaf 1978.

Vervolgens bespreken wij de resultaten van twee kiezersonderzoeken, waaruit de stemmotieven van kiezers bij lokale verkiezingen in respectievelijk de gemeenten Heerlen en Sittard en de gemeente Echt naar voren komen.

Het beeld dat de politicus heeft van de band met 'zijn' kiezers levert een verdere aanwijzing op voor de aard van deze band. Daartoe worden enkele gegevens van de mondelinge en schrittelijke lijsttrekkersenquêtes benut. Een eerste ingang om de perceptie van de politicus op het spoor te komen, is de wijze waarop hij verkiezingscampagne voert. Men kan verwachten dat de campagnemiddelen aansluiten bij de door de kandidaat veronderstelde aard van de binding met zijn kiezers. Daarnaast is gevraagd naar het beeld dat de lijsttrekkers hebben van de stemmotieven van de eigen aanhang en naar de opvatting met betrekking tot de eigen rol ten opzichte van de kiezers.

In de tweede paragraaf worden de onderzoeksbevindingen nader geïnterpreteerd en zal worden ingegaan op de mogelijke gevolgen van het nationaliseringsproces voor de band tussen kiezers en gekozenen.

\subsection{Beschrijving van onderzoeksresultaten}

\section{a. Voorkeurstemmen}

In hoofdstuk 3 is aan de hand van verkiezingsstatistieken een beschrijving gegeven van enkele kenmerken van de Limburgse lokale politiek. Relevant voor het onderwerp van dit hoofdstuk zijn, naast de opkomsicijfers, met name de gegevens betreffende de voorkeurstemmen van Limburgse kiezers. Het uitbrengen van een voorkeurstem geeft 
op zijn minst aan dat de kiezer naast de keuze voor een bepaalde lijst of partij ook een bijzondere voorkeur vertoont voor een bepaalde kandidaat. De band met de politiek heeft in dat geval deels een persoonlijk karakter. Toch moet bij de interpretatie van de percentages uitgebrachte voorkeurstemmen enige voorzichtigheid betracht worden. De mate waarin Limburgse kiezers een persoonlijke band met lokale politici ervaren kan om tenminste twee redenen niet aan de hand van het (provinciale) percentage voorkeurstemmen nauwkeurig gë̈ndiceerd worden.

In de eerste plaats kan men niet zonder meer aannemen dat de stemmers op de lijsttrekkers primair een partij in plaats van een persoon hebben gekozen. De lijsttrekker zelf is - zeker bij lokale lijsten - gewoonlijk een welbekende en populaire persoon en het is aannemelijk dat er op de betreffende politicus veel 'onzichtbare' maar niet minder bewuste voorkeurstemmen worden uitgebracht. Het persoonlijke element in de band tussen kiezers en kandidaten wordt om deze reden onderschat wanneer men slechts af zou gaan op de percentages voorkeurstemmen.

Een tweede voor de interpretatie van deze gegevens problematische factor vormt de echo van voorkeursacties voor vrouwelijke politici. Kiezers die gehoor geven aan dit soort acties ervaren niet altijd een persoonlijke band met de politica van hun keuze. Dit leidt ertoe dat het percentage voorkeurstemmen ook kan leiden tot een zekere overschatting van de mate waarin de bindingen in de lokale politiek een persoonlijk karakter hebben.

Illustratief voor de werking van deze tweede factor was de situatie in de Noordlimburgse gemeente Arcen en Velden in 1990. De vrouwelijke kandidaten hadden geen verkiesbare plaatsen op de diverse lijsten verkregen. Om te voorkomen dat er geen vrouwen verkozen zouden worden, werd er een intensicve voorkeursactie voor vrouwelijke kandidaten gevoerd, los van de lijsten waarvoor ze uitkwamen. Het resultaat van deze actie was dat vijf van deze vrouwelijke kandidaten verkozen werden. Het percentage voorkeurstemmen in deze gemeente bedroeg ruim 75 procent, beduidend meer dan het Limburgs gemiddelde.

Uit de in hoofdstuk 3 weergegeven cijfers (tabellen 3.5 en 3.20), blijkt dat in Limburg aanzienlijk meer voorkeurstemmen werden afgegeven dan in andere provincies. Het percentage in de provincie Limburg uitgebrachte voorkeurstemmen bij gemeenteraadsverkiezingen lag in de periode van 1974 tot en met 1982 steeds tussen de vijftig en zestig procent, ongeveer twee keer zoveel als het landelijk gemiddelde. Over de jaren 1986 en 1990 zijn alleen de Limburgse cijfers bekend, waaruit een verder stijgende tendens naar voren komt.

Niet voor elke partij was het verschil tussen het aantal voorkeurstemmen in Limburg en de rest van het land overigens even groot. De cijfers voor een aantal partijen bij de gemeenteraadsverkiezingen van 1978 en 1982 zijn in tabel 5.1 weergegeven ${ }^{1}$.

Uit tabel 5.1 wordt duidelijk dat in Limburg de aanhang van het CDA, de lokale lijsten en de VVD relatief de meeste voorkeurstemmen uitbracht. Het contrast op dit

1 Gelet op de geringe deelname van landelijke lijsten aan Limburgse gerneenteraadsverkiezingen voor 1978 is afgezien van uitsplitsing naar partijen voor eerdere verkiezingsjaren. 
Tabel 5.1. Voorkeurstemmen in Limburg en Nederland bij gemeenteraadsverkiezingen in 1978 en 1982, naar partij (als percentage van het totaal aantal uitgebrachte geldige stemmen).

\begin{tabular}{|c|c|c|c|c|c|c|}
\hline & \multicolumn{3}{|l|}{1978} & \multicolumn{3}{|l|}{1982} \\
\hline & Limburg & $\begin{array}{l}\text { Overig } \\
\text { Nederland }\end{array}$ & verschil & Limburg & $\begin{array}{l}\text { Overig } \\
\text { Nederland }\end{array}$ & verschil \\
\hline CDA & 59 & 25 & 34 & 63 & 25 & 38 \\
\hline PvdA/PAK & 37 & 23 & 14 & 41 & 26 & 15 \\
\hline VVD & 49 & 27 & 22 & 47 & 25 & 22 \\
\hline D66 & 25 & 20 & 5 & 43 & 25 & 18 \\
\hline Lokale lijsten & 45 & 33 & 12 & 60 & 33 & 27 \\
\hline Totaal & 53 & 25 & 28 & 56 & 26 & 30 \\
\hline
\end{tabular}

Bron: CBS, Statistiek der Verkiezingen

punt tussen het Limburgse cijfer en het percentage in de rest van Nederland is vooral voor het CDA bijzonder groot.

Uit de in tabel 5.2 weergegeven Limburgse cijfers over de latere jaren blijkt dat het verschil tussen de PvdA en de VVD aan de ene kant en het CDA en de lokale lijsten aan de andere kant, is verkleind. Bij D66 was daarentegen sprake van een lichte daling van het aantal op andere kandidaten dan op de lijsttrekker uitgebrachte stemmen.

Op het eerste gezicht lijkt het vreemd dat juist bij lokale lijsten die veelal in hoge mate gecentreerd lijken rond een lijsttrekker als belangrijkste stemmentrekker het percentage voorkeurstemmen dermate groot is. Voor een mogelijke verklaring van dit paradoxale gegeven kan in de eerste plaats gewezen worden op het feit dat de lager geplaatsten op de lijst veelal heel bewust uitverkoren werden met het oog op de grote persoonlijke achterban die zij voor de lijst meebrachten, zonder dat dit direkt afbreuk hoefde te doen aan de positie als grootste stemmentrekker van de lijsttrekker. Daarnaast was er sprake van een tamelijk grote instabiliteit onder de kiezers, zoals onder andere bleek uit de eerder aangehaalde case-studies. Lijsttrekkers zagen daardoor van de ene op de andere verkiezing hun populariteit soms scherp dalen ten gunste van lager geplaatsten op de lijst, waardoor het percentage voorkeurstemmen hoog kon uitvallen.

De forse stijging van het percentage voorkeurstemmen bij lokale lijsten tussen 1978 en 1982, kan overigens in verband worden gebracht met het afnemende aantal deelnemende lokale lijsten per gemeente (zie hoofdstuk 3). De overblijvende lijsten hebben veelal raadsfracties van meer dan drie personen, waardoor de kans dat de lijsttrekker het merendeel van de voorkeurstemmen naar zich toetrekt verder is afgenomen.

Eerder is gewezen op het risico van een zekere mate van over- dan wel onderschatting van het aantal persoonsgebonden kiezers. Aangezien de omvang van die effecten niet te meten is, geeft het relatief grote aantal voorkeurstemmen bij Limburgse raadsverkiezingen slechts een eerste indicatie van het feit dat veel Limburgse kiezers 
Tabel 5.2. Aantal in Limburg bij gemeenteraadsverkiezingen uitgebrachte voorkeurstemmen in 1982 , 1986 en 1990, (als percentage van het totaal aantal uitgebrachte geldige stemmen).

\begin{tabular}{llll}
\hline & 1982 & 1986 & 1990 \\
\hline CDA & 63 & 63 & 67 \\
PvdA/PAK & 41 & 44 & 50 \\
VVD & 47 & 51 & 55 \\
D66 & 43 & $*$ & 37 \\
Lokale lijsten & 60 & $*$ & 62 \\
Totaal Limburg & 56 & 56 & 59 \\
\hline
\end{tabular}

* Voor deze partijen c.q. lijsten zijn geen afzonderlijke gegevens verzameld.

Bron: CBS, Statistiek der verkiezingen (1982) en opgaven gemeenten (1986 en 1990)

een persoonlijke band met plaatselijke politici ervaren. Enkele kiezersonderzoeken hebben dit op een meer direkte wijze zichtbaar gemaakt.

\section{b. Resultaten kiezersonderzoeken}

\section{Kiezersonderzoek Sittard en Heerlen}

In 1981 werd door het onderzoeksbureau Ferro b.v., in opdracht van de PvdA een kiezersonderzoek verricht in de Zuidlimburgse gemeenten Heerlen en Sittard (Ferto b.v., 1982). Daarbij zijn een honderdtal kiezers geïnterviewd die bij de Tweede Kamerverkiezingen van 1981 op de Partij van de Arbeid hadden gestemd, maar bij gemeenteraadsverkiezingen in dat zelfde jaar aan een andere lijst his. voorkeur hadden gegeven.

De onderstaande, aan de enquêteurs kenbaar gemaakte, stemmotieven laten zien dat deze (stedelijke) kiezers in veel gevallen een persoonlijke binding hadden met de kandidaat van hun voorkeur.

"Dhr. $\mathrm{x}$ is administrateur van onze school, hij staat altijd voor je klaar."

"lemand van die partij heeft mij geholpen aan een woning."

"Dhr. $\mathrm{x}$ woont bij ons achter, hij wil zorgen voor raampjes in de douchenuimte, hij is zelf longpatiënt."

"Ik ken er iemand van die mijn moeder heeft geholpen met het vindern van eern nieuwe woning."

"Die man zei: "Als het zover is dat ik gekozen word, dan help ik je wel". Maar dat moet je met een korreltje zout nemen, want nu hoor je er niets meer van."

In de bovenstaande gevallen ging het naast een persoonlijke band steeds om een vorm van dienstverlening die tegenover het geven van een stem stond. De volgende voorbeelden laten zien dat een persoonlijke band niet in alle gevallen met dit soort dienstverlening samenhing.

"Ken die man erg goed, dat hij bij het CDA staat, maakt voor mij niets uit."

"Hij kwam dat hier aan de deur vragen. Het maakte ons niets uit en wij kenden elkaar goed." 
"Bij gemeenteraadsverkiezingen stem je op iemand, niet op een partij."

"Je krijgt er geen hoogte van wie er in zit, daarom stem je op iemand die je kent ook al ken je dan de partij niet."

"Dhr. $x$ doet nogal veel. Ook met kerstmis en met verjaardagen kom! hij met een fruitschaal. Op de avonden voor gehandicapten komt hij ook altijd."

Aan de respondenten werd ook gevraagd om de stemmotieven van de aanhang van lokale lijsten in de eigen gemeente in te schatten. Deze antwoorden, waarvan opnieuw een aantal voorbeelden worden weergegeven, bevestigden het beeld van een sterk persoonlijke band tussen kiezers en gekozenen.

"Men kent Jantje of Pietje goed en dan zal het hun verder een zorg zijn."

"Omdat goeie kennissen hun dat vragen. Hebben er dan persoonlijke voordelen van."

"Komen veel langs de deur leuren om stemmen te krijgen."

"Hebben er iets van gedaan gekregen. Kiezers zijn geholpen door lijsttrekkers."

In tabel 5.3 zijn de verschillende motieven die volgens de respondenten een rol speelden bij de keuze van kiezers in hun gemeente voor het CDA, de PvdA, respectievelijk de lokale lijsten in een aantal categorieën gerangschikt. 2

$\mathrm{Bij}$ het stemmen op lokale groeperingen werd vooral de aanwezigheid van aansprekende personen als belangrijk motief gezien. Opvallend is dat - anders dan bij de landelijke partijen - niemand verwachtte dat kiezers uit gewoonte hun stem zouden geven aan de lokale lijsten.

Aan de keuze voor het CDA lagen volgens de respondenten met name de categorieën 'geloof/overtuiging' en 'aansprekende partij/programma' ten grondslag. Deze laatste categorie werd ook bij de PvdA-aanhang een belangrijke rol toebedacht. Voor de PvdA werd daamaast de inzet voor een bepaalde sociaal-economische groep van belang geacht.

De onderzoekers concludeerden dat vooral bij de aanhang van de lokale lijsten het belangrijkste keuzemotief bij de gemeenteraadsverkiezingen de persoonlijke bekendheid met de kandidaat vormde (Ferro b.v., 1982:37 e.v.). Bovendien constateerden zij dat in 1981, in vergelijking met 1978, de persoonlijke aard van de binding nog was toegenomen. De lage score van de PvdA bij de gemeenteraadsverkiezingen, in vergelijking met de uitslag bij Tweede Kamerverkiezingen in de betreffende gemeenten ${ }^{3}$, werd dan ook toegeschreven aan een gebrek aan lokaal aansprekende persoonlijkheden op de PrdA-lijst.

\section{Kiezersonderzoek Echt}

In het voorjaar van 1989 werden honderd kiezers in de Middenlimburgse gemeente Echt geïnterviewd (Ohlenforst, 1992). Uit een vergelijking tussen de uitslagen van de

2 De in totaal 102 respondenten konden meerdere categorieën aangeven.

3 Bij de I'weede Kumerverkiezingen van 1981 haalde de PvdA in Heerlen 30,2 procent en in Sittard 28,4 procent van de geldig uitgebrachte stemmen. Bij de gemeenteraadsverkiezingen in dat zelfde jaar haalde de PvdA in Heerlen 13,1 procent en de PAK-lijst in Sitzard 8,9 procent. 
Tabel 5.3. Door respondenten opgegeven stemmotieven van kiezers op CDA, PvdA en lokale lijsten in Sittard en Heerlen.

\begin{tabular}{lcccc}
\hline & CDA & PvdA & Lokale lijsten & Totaal \\
\hline aansprekende partij/programma & $18 \%$ & $23 \%$ & $25 \%$ & $22 \%$ \\
overtuiging/geloof & $30 \%$ & $7 \%$ & - & $13 \%$ \\
inzet voor sociaaleconomische groep & $3 \%$ & $25 \%$ & - & $9 \%$ \\
gewoonte & $11 \%$ & $15 \%$ & - & $9 \%$ \\
aansprekende personen & $16 \%$ & $10 \%$ & $62 \%$ & $29 \%$ \\
weet niet & $22 \%$ & $20 \%$ & $13 \%$ & $18 \%$ \\
Totaal aantal opgegeven motieven & $100 \%$ & $100 \%$ & $100 \%$ & $100 \%$ \\
& $(120)$ & $(117)$ & $(111)$ & $(348)$ \\
\hline
\end{tabular}

Bron: Kiezersonderzoek Ferro b.v. (1981)

Tabel 5.4. Aantal respondenten dat in 1982 bewust of niet bewust op een persoon heeft gestemd, naar type lijst.

\begin{tabular}{llll}
\hline Stem op persoon: & Lokale lijst & Landelijke lijst & Totaal \\
\hline wel bewust & $97 \%$ & $26 \%$ & $79 \%$ \\
niet bewust & $3 \%$ & $74 \%$ & $21 \%$ \\
Totaal & $100 \%$ & $100 \%$ & $100 \%$ \\
& $(68)$ & $(23)$ & $(91)$ \\
\hline
\end{tabular}

$\mathrm{chi}^{2}=52,43 ;(p \leq 0,005)$

Bron: Kiezersonderzoek Echt, Ohlenforst, 1992.

gemeenteraadsverkiezingen van 1982 en 1986 en de opgave van de respondenten van hun stemgedrag bij die verkiezingen, bleek dat de steekproef qua politieke voorkeur ongeveer overeen kwam met het totale electoraat in Echt.

Een deel van de vragenlijst betrof de mate waarin kiezers bewust op personen stemden en de redenen daarvoor. Op de vraag: "Stemde u toen (in 1982, respectievelijk 1986) bewust op een bepaalde persoon?", antwoordde meer dan driekwart van de respondenten dat dat inderdaad het geval was. Wel was er beide keren een duidelijk verschil tussen kiezers van lokale lijsten en aanhangers van landelijke lijsten. Op een enkele uitzondering na stemden alle lokale lijststemmers bewust op een persoon, bij de andere respondenten was dit slechts bij ongeveer eenderde het geval. In tabel 5.4 is het overzicht voor 1982 weergegeven, voor de 91 respondenten die aangaven in dat jaar te hebben gestemd.

Van de bewust op personen stemmende respondenten gaf bovendien circa 90 procent aan dat men de betrokken politicus ook persoonlijk kende. Van alle respondenten samen had dus ongeveer 80 procent een (door henzelf ervaren) persoonlijke 
band met de politicus van hun keuze. Eenderde van de kiezers gaf aan de betreffende persoon zelfs maandelijks of vaker te spreken.

Om na te gaan waaruit de persoonlijke band tussen kiezers en gekozenen voortkwam, werd verder gevraagd naar de motieven om juist op die betreffende politicus te stemmen. Deze vraag had een open karakter. De variatie van de stemmotieven bleek buitengewoon groot.

In de eerste plaats waren er enkele personen die als enig motief noemden, het feit dat de kandidaat een familielid was. Daarnaast werden stemmotieven opgegeven die betrekking hadden op gevoelde sympathie voor, dan wel instemming met, de (politieke) daden van de politicus. Enkele voorbeelden van dit soor motieven zijn:

"Ik hen het eens met zijn principes."

"Hij heeft in het verleden goede dingen in de politiek gedaan."

"Hij is betrouwbaar en eerlijk."

Vervolgens stemden verschillende respondenten op de persoon omdat ze hem kenden, met name omdat hij in hetzelfde kerkdorp woonde. Ook werden er antwoorden gegeven waarin sprake was van de inzet van de betrokkene voor de gemeenschap dan wel de belangenbehartiging voor het kerkdorp. Voorbeelden van dit type antwoorden zijn:

"Hij doet iets voor de gemeenschap en niet voor zichzelf."

"Hij vertegenwoordigt de belangen van dorp X en Y."

Een laatste categorie wordt gevormd door stemmotieven die te maken hadden met enigerlei vorm van dienstverlening door de betreffende politicus. Deze dienstverlening had veelal betrekking op belastingaangifte en bouwvergunningen. Ook de reputatie van kandidaten als dienstverlener speelde een rol. Ook van deze categorie geven wij hieronder enkele typerende voorbeelden:

"Omdat ik verhalen had gehoord dat hij iemand persoonlijk hielp."

"Als ik geholpen moest worden, hielp hij mij ook."

"Wegens een verleende familie-dienst."

"Ik ken hem persoonlijk en je kunt er met een probleem naar toe."

De mate van dienstverlening door politici is ook op een meer direkte wijze gepeild door de vraag of de persoon op wie men gestemd had de respondent zelf of éen van zijn familieleden in het verleden ooit geholpen had wanneer zich een probleem, moeilijkheid of karwei voordeed. In de aanloop naar de verkiezingen van 1982 waren 19 van de 91 respondenten zelf geholpen en 15 respondenten meldden dat de betreffende politicus diensten had verleend aan een naast familielid van de respondent. (In 1986 waren er dat respectievelijk 23 en 18 van de in totaal 97 respondenten.)

Nog belangrijker bleek echter de reputatie van dienstverlener te zijn. Aan diegenen die een bewuste voorkeurstem hadden uitgebracht werd de volgende vraag voorgelegd: "Denkt $u$ dat het van belang is dat deze persoon u kan helpen wanneer zich in de toekomst een probleem, moeilijkheid of karwei voordoet?" De helft van de betreffende respondenten antwoordde hier positief op. 
Een laatste aanwijzing voor de mate waarin de band tussen kiezers en gekozenen samenhangt met de factor dienstverlening, vormt de respons op een stelling die op de funktie van raadsleden betrekking heeft. Deze stelling luidde als volgt:

"De belangrijkste funktie van een raadslid is om een soort ombudsman te zijn voor burgers die met hun problemen naar hem/haar komen."

Uit de antwoorden blijkt dat de meerderheid van de respondenten inderdaad verwachtte dat de leden van de raad als een soort ombudsman zouden opereren, (zie tabel 5.5).

Uit het kiezersonderzoek in Echt komt overigens wel naar voren dat jonge kiezers eerder voor een landelijke partij kozen, minder geneigd waren om bewust op personen te stemmen en minder waarde hechtten aan het 'ombudsmanschap' van raadsleden.

Tabel 5.5. Mate waarin respondenten de ombudsmanrol als belangrijkste functie van een raadslid beschouwen.

Aantal respondenten

\begin{tabular}{lr}
\hline helemaal niet mee eens & 4 \\
niet mee eens & 12 \\
noch eens, noch oneens & 21 \\
mee eens & 27 \\
helemaal mee eens & 36 \\
Totaal & 100 \\
\hline
\end{tabular}

Bron: Kiezersonderzoek Echt, OhJenforst. 1992.

\section{Conclusie}

De twee beschreven kiezersonderzoeken leveren, ondanks het feit dat het eén in een stedelijke en het ander in een dorpse omgeving is uitgevoerd, geen groot contrast op ten aanzien van de aard van de binding tussen kiezers en gekozenen. Uit beide studies komt de sterk persoonlijke band tussen kiezers en gekozenen in Limburg naar voren, die vooral opgaat voor de kiezers op lokale lijsten. De aard van de binding hangt voorts in veel gevallen samen met behaalde of mogelijk te verwachten voordelen, dankzij de dienstverlening door de betreffende politicus.

\section{c. Resultaten lijsttrekkersenquêtes}

Een aantal onderdelen van de lijsttrekkersenquêtes verschaft inzicht in de perceptie van de politicus van de band met de eigen achterban. Achtereenvolgens zullen wij gegevens behandelen die betrekking hebben op de verkiezingscampagne, het beeld van de stemmotieven van de eigen aanhang en de rolopvatting van de politici. 


\section{Verkiezingscampagne}

Door middel van verkiezingscampagmes proberen politici zoveel mogelijk stemmen voor hun lijst te vergaren. Het ligt voor de hand dat de middelen die men daartoe benut aansluiten bij het beeld dat men heeft van de stemmotieven van de kiezers. Men zal, met andere woorden, inspelen op de wijze waarop de kiezers gebonden zijn aan politici in het betreffende politieke systeem. Wanneer kiezers in hoge mate beleidsgeoriënteerd zijn, is het logisch dat politici hen proberen te overtuigen met behulp van verkiezingsprogramma's, verspreiding van folders waarin standpunten worden uiteengezet, het houden van toespraken en het meedoen aan forumdiscussies. Gaat het de kiezer primair om de persoon van de kandidaat, om diens bekendheid en hulpvaardigheid, dan zal het accent in de campagne liggen op het zoveel mogelijk contact zoeken met burgers bijvoorbeeld door bij openbare gelegenheden uitdrukkelijk aanwezig te zijn. Het plegen van huisbezoeken ('canvassing') is een campagnemiddel dat op beide oriëntaties van kiezers aansluit.

Met behulp van de schriftelijke enquête is een beeld ontstaan van de campagnemethoden die door de verschillende typen lijsten in 1982 gehanteerd werden. Tabel 5.6 geeft hiervan een overzicht. De percentages in de cellen geven aan in welke mate de verschillende in de tabel opgesomde methoden door de plaatselijke groeperingen, respectievelijk afdelingen van landelijke partijen in de steekproef werden gebruikt. (Uit de eerste cel is bijvoorbeeld af te lezen dat 90 procent van de lokale lijsten folders gebruikte tijdens de verkiezingscampagne.)

De landelijke lijsten voerden (op een enkele uitzondering na) campagne met behulp van folders, posters, toespraken en advertenties. Voor deze vier activiteiten geldt dat lokale lijsten er minder gebruik van maakten dan landelijke lijsten. Lokale lijsten waren daarentegen actiever als het gaat om contacten met burgers en huisbezoeken.

Tabel 5.6. Door lijstrekkers opgegeven bij de raadsverkiezingen van 1982 gehanteerde campagnemethoden, naar type lijst.

\begin{tabular}{llll}
\hline & $\begin{array}{l}\text { Lokale } \\
\text { lijsten }\end{array}$ & $\begin{array}{l}\text { Landelijke } \\
\text { lijsten }\end{array}$ & Totaal \\
\hline folders & $90 \%$ & $96 \%$ & $93 \%$ \\
posters & $74 \%$ & $93 \%$ & $83 \%$ \\
advertenties & $65 \%$ & $93 \%$ & $78 \%$ \\
toespraken, fora & $32 \%$ & $93 \%$ & $60 \%$ \\
contact burgers* & $65 \%$ & $52 \%$ & $59 \%$ \\
overige publiciteit & $39 \%$ & $63 \%$ & $50 \%$ \\
huisbezoeken & $55 \%$ & $41 \%$ & $48 \%$ \\
& & & \\
Totaal aantal respondenten & $(31)$ & $(27)$ & $(58)$ \\
\hline
\end{tabular}

* De volledige aanduiding van deze activiteit luidde: "Zoveel mogelijk concact met burgers in openbare gelegenheden, bij feesten etc.".

Bron: Lijsttrekkersenquête, RL 
Naast de vraag naar het gebruik van de verschillende campagnemethoden, is aan de lijsttrekkers ook gevraagd om aan te geven in hoeverre men de verschillende onderdelen van de campagne van belang achtte voor het succes van de eigen lijst. De betreffende vraag luidde: "In welke mate dragen volgens u deze (onderstaande) campagne-activiteiten bij tot succes van uw lijst bij raadsverkiezingen?" In Appendix II, tabel II.1 is de respons per onderdeel weergegeven.

Slechts weinig respondenten meenden dat het plaatsen van advertenties, ophangen van posters en het houden van toespraken veel hadden bijgedragen aan het eigen succes. Niettemin werden deze drie activiteiten door vrijwel alle landelijke lijsten ontplooid. Voor de vierde activiteit die tot het 'standaard-pakket' van landelijke en ook veel lokale lijsten behoorde - het verspreiden van folders - gold dat in mindere mate. Opvallend positief hierover waren de lijsttrekkers van lokale lijsten, terwijl de respondenten van landelijke lijsten sceptischer tegenover de bijdrage van dit campagnemiddel stonden.

De activiteit die volgens verreweg de meeste lijsttrekkers veel bijdroeg aan succes bij verkiezingen is het zoveel mogelijk contact maken met burgers in openbare gelegenheden. Lijsttrekkers van lokale lijsten en het CDA waren over deze campagnemethode overigens positiever dan hun collega's van de overige landelijke lijsten. Over het effekt van huisbezoeken liepen de meningen van de respondenten sterk uiteen.

De in Appendix I, tabel II.1 afgedrukte gegevens vormen de basis voor de berekening van de gemiddelde respons van de drie categorieën respondenten bij de verschillende items, die in tabel 5.7 is weergegeven. Dit gemiddelde komt tot stand door een weging van de antwoorden op de volgende wijze: aan het antwoord 'veel' zijn drie punten toegekend, aan het antwoord 'matig' twee en aan het antwoord 'weinig' éen. Per categorie is vervolgens het op deze wijze verkregen puntentotaal gedeeld door het aantal respondenten. (De in tabel 5.7 verkort aangeduide factoren corresponderen met de in tabel 5.6 vollediger weergegeven factoren.)

Tabel 5.7. Mate waarin campagne-activiteiten volgens lijsttrekkers bijdragen aan het eigen succes, naar type lijst.

\begin{tabular}{|c|c|c|c|c|}
\hline & $\begin{array}{l}\text { Lokale } \\
\text { lijsten }\end{array}$ & CDA & $\begin{array}{l}\text { Ov. landelijke } \\
\text { lijsten }\end{array}$ & Totaal \\
\hline folders verspreiden & 2,3 & 2,2 & 1,9 & 2,1 \\
\hline advertenties & 1,7 & 2,2 & 1,9 & 1,9 \\
\hline posters ophangen & 1,9 & 2,2 & 2,0 & 2,0 \\
\hline toespraken etc. & 1,6 & 1,4 & 2,0 & 1,7 \\
\hline contact met burgers & 2,4 & 2,3 & 1,8 & 2,2 \\
\hline overige publiciteit & 1,3 & 1,8 & 2,0 & 1.6 \\
\hline huisbezoeken & 2,0 & 2,3 & 1,8 & 2,0 \\
\hline aantal respondenten & (31) & (9) & $(18)$ & $(58)$ \\
\hline
\end{tabular}

Bron: Lijsttrekkersenquête, RL 
Het verspreiden van folders, contacten met burgers en huisbezoeken werden gemiddeld genomen belangrijker geacht voor het eigen succes door respondenten van lokale lijsten en het CDA, dan door respondenten van overige landelijke lijsten. Deze laatsten schatten daarentegen het gewicht van toespraken, bijdragen aan forumdiscussies en overige publiciteit voor hun succes gemiddeld hoger in dan de eerder genoemde respondenten.

De gegevens betreffende de verkiezingscampagne in 1982 versterken de indruk dat de binding tussen kiezers en gekozenen in de Limburgse lokale politiek in belangrijke mate persoonlijk van aard was. De daarbij aansluitende persoonlijke benadering tijdens verkiezingscampagnes werd door de politici over het algemeen als het meest waardevol gezien, hoewel de landelijke lijsten in de steekproef op dat punt beduidend minder actief waren dan de lokale lijsten.

\section{Stemmotieven eigen aanhang}

Om op meer directe wijze zicht te krijgen op de visie van de politici is bij de schriftelijke enquête aan de lijsttrekkers de volgende vraag voorgelegd: "Bij de keuze van de kiezers voor uw lijst in 1982 zullen verschillende zaken een rol hebben gespeeld. Kunt u aangeven hoe belangrijk naar uw mening de hieronder genoemde zaken waren?" De volgende zaken werden aan de respondent voorgelegd:

- de inzet voor individuele kiezers door open te staan voor en te helpen bij hun persoonlijke problemen;

- de persconlijke inzet in de plaatselijke gemeenschap;

- de standpunten van de lijsttrekkers en diens groepering bij bepaalde beleidskwesties;

- de afkomst uit een bepaald dorp of stadsdeel;

- het verkiezingsprogramma van de groepering;

- ontwikkelingen in de landelijke politiek.

De respons uitgesplitst per factor is in Appendix II, tabel II.2 opgenomen.

Het openstaan voor problemen van individuele kiezers en de persoonlijke inzet binnen de plaatselijke gemeenschap werden door een groot aantal respondenten als heel belangrijke factoren voor hun succes gezien. Respondenten van lokale lijsten en van het CDA waren vrijwel eensgezind in hun oordeel hierover. De lijsttrekkers van de overige landelijke lijsten weken van deze categorieën significant af doordat er binnen deze groep meer personen waren die deze twee factoren als niet of slechts enigszins belangrijk bestempelden.

Het belang van de standpunten in bepaalde beleidskwesties werd daarentegen door vrijwel iedereen in alle drie lijstcategorieën onderkend. In iets mindere mate gold dat ook voor de verkiezingsprogramma's. Significante verschillen tussen de drie typen lijstrekkers werden ten aanzien van deze factoren niet gevonden.

De overige factoren die aan de respondenten zijn voorgelegd lieten daarentegen een gevarieerd beeld zien. Bij de lokale lijsten valt op dat een grote groep de afkomst uit een bepaald dorp of stadsdeel als heel belangrijk noemde. Bij de landelijke lijsten speelde deze factor kennelijk een minder gewichtige rol. 
De grootste verschillen deden zich voor ten aanzien van de inschatting van de rol van ontwikkelingen in de landelijke politiek. Dat deze ontwikkelingen voor de lokale lijsten over het algemeen niet zo belangrijk waren, is weinig verrassend. Bij de landelijke lijsten zou men een tegenovergestelde beoordeling verwachten. Met uitzondering van de CDA'ers bleek dat ook het geval te zijn; slechts éen CDA-respondent meende daarentegen dat de ontwikkelingen in de landelijke politiek heel belangrijk voor de keuze van zijn kiezers waren.

Analoog aan de beschrijving van onderzoeksgegevens met betrekking tot het belang van de diverse campagne-activiteiten, zijn ook op basis van de in Appendix II, in tabel II. 2 weergegeven data, gemiddelden berekend voor de diverse categorieën respondenten. Aan de antwoorden 'heel belangrijk', 'enigszins belangrijk' en 'niet of nauwelijks belangrijk', werden daarbij achtereenvolgens drie punten, twee punten en één punt toegekend, waarna per categorie de puntentotalen werden gedeeld door het aantal respondenten. Het resultaat is in tabel 5.8 zichtbaar. (De in deze tabel verkort aangeduide factoren corresponderen met de hierboven vollediger weergegeven factoren.)

De persoonlijke inzet voor individuele kiezers en de gemeenschap als geheel, alsmede de afkomst uit een bepaald dorp of een bepaalde wijk waren factoren die door respondenten van lokale lijsten en het CDA gemiddeld van groter belang geacht werden dan door de overige respondenten. Bij deze laatste categorie, de respondenten van overige landelijke lijsten, scoorde de factor 'ontwikkelingen in de landelijke politiek' beduidend hoger dan bij de andere categorieën.

Het contrast tussen de drie typen lijsten is eveneens zichtbaar bij de respons op de vraag welke factor volgens de lijsttrekkers het zwaarst woog bij de keuze van de kiezers voor hun lijst, in 1982.4

Tabel 5.8. Oordeel van de lijsttrekkers over het belang van diverse factoren bij de keuze van de eigen kiezers, naar type lijst.

\begin{tabular}{|c|c|c|c|c|}
\hline & $\begin{array}{l}\text { Lokale } \\
\text { lijsten }\end{array}$ & CDA & $\begin{array}{l}\text { Ov. landelijke } \\
\text { lijsten }\end{array}$ & Totaal \\
\hline inzet voor kiezers & 2,7 & 3,0 & 2,2 & 2,6 \\
\hline inzet in gemeenschap & 2,9 & 2,7 & 2,4 & 2.7 \\
\hline standpunten beleidskwesties & 2,7 & 2,4 & 2,8 & 2,7 \\
\hline afkomst uit dorp/buurt & 2,0 & 2,1 & 1,2 & 1,8 \\
\hline verkiezingsprogramma & 2,3 & 2,0 & 2,0 & 2,1 \\
\hline landelijke politiek & 1,3 & 1,8 & 2,7 & 1,8 \\
\hline aantal respondenten & $(31)$ & (9) & (18) & $(58)$ \\
\hline
\end{tabular}

Bron: Lijsttrekkersenquête, RL

4 Een aantal lijsttrekkers vulde twee in plaats van één faktor in. In die gevallen zijn beide faktoren meegeteld. De celfrequenties in deze tabel laten het niet toe om de chi ${ }^{2}$-significantietoets uit te voeren. 
Tabel 5.9. Lijsttrekkers naar factor die zwaarst woog bij keuze eigen kiezers en type lijst.

\begin{tabular}{lcccc}
\hline & $\begin{array}{c}\text { Lokale } \\
\text { lijsten }\end{array}$ & CDA & $\begin{array}{l}\text { Ov. landelijke } \\
\text { lijsten }\end{array}$ & Totaal \\
\hline $\begin{array}{l}\text { inzet voor kiezers } \\
\text { inzet in gemeenschap }\end{array}$ & $18 \%$ & $30 \%$ & $17 \%$ & $19 \%$ \\
standpunten beleidskwesties & $50 \%$ & $40 \%$ & $22 \%$ & $40 \%$ \\
afkomst uit dorp/buurt & $14 \%$ & $30 \%$ & $39 \%$ & $24 \%$ \\
verkiezingsprogramma & $9 \%$ & - & - & $5 \%$ \\
landelijke politiek & $9 \%$ & - & - & $5 \%$ \\
Totaal & - & - & $22 \%$ & $6 \%$ \\
& $100 \%$ & $100 \%$ & $100 \%$ & $100 \%$ \\
\hline
\end{tabular}

(* in totaal vier respondenten vulden abusievelijk twee factoren in waardoor zij in deze tabel dubbel tellen)

Bron: Lijsttrekkersenquête, $R L$

Tabel 5.10. Mate waarin lijsturekkers de ombudsmanrol als belangrijkste funktie van raadsleden zien, naar type lijst.

\begin{tabular}{lllll}
\hline & $\begin{array}{l}\text { Lokale } \\
\text { lijsten }\end{array}$ & CDA & \multicolumn{2}{c}{ Ov. landelijke } \\
& $17 \%$ & $40 \%$ & $52 \%$ & $31 \%$ \\
niet mee eens & $7 \%$ & $20 \%$ & $24 \%$ & $14 \%$ \\
noch eens noch oneens & $76 \%$ & $40 \%$ & $24 \%$ & $55 \%$ \\
mee eens & $100 \%$ & $100 \%$ & $100 \%$ & $100 \%$ \\
Totaal & $(54)$ & $(10)$ & $(33)$ & $(97)$ \\
geen antwoord & 1 & - & - & 1 \\
\hline
\end{tabular}

$\mathrm{chi}^{2}=23,01 ;(p \leq 0,005)$

Tabel 5.11. Mate waarin lijsttrekkers door burgers benaderd werden, naar type lijst.

\begin{tabular}{lccc}
\hline & $\begin{array}{l}\text { Lokale } \\
\text { lijsten }\end{array}$ & $\begin{array}{l}\text { Landelijke } \\
\text { lijsten }\end{array}$ & Totaal \\
\hline vaak & $83 \%$ & $86 \%$ & $84 \%$ \\
soms & $13 \%$ & $11 \%$ & $12 \%$ \\
zelden/nooit & $4 \%$ & $3 \%$ & $4 \%$ \\
Totaal & $100 \%$ & $100 \%$ & $100 \%$ \\
& $(40)$ & $(36)$ & $(76)$ \\
\hline
\end{tabular}

chi $^{2}=0.49$; (niet-sign.)

Bron: Lijsttrekkersenquête. RL 
Uit tabel 5.9 blijkt opnieuw dat de persoonlijke inzet binnen de gemeenschap als succesfactor hoog werd aangeslagen, met name in de kring van de lokale lijsten en het CDA. Ook de individuele inzet voor kiezers werd door nogal wat lijsttrekkers als belangrijkste thema gezien. Een groot aantal respondenten van de overige landelijke partijen achtte de eigen standpunten en de ontwikkelingen in de landelijke politiek het meest belangrijk. De positie van de CDA-respondenten valt bij deze vergelijking in het bijzonder op: deze laatste factor werd door geen van hen als de belangrijkste gezien.

Het verkiezingsprogramma werd, op een enkele uitzondering na, door de lijsttrekkers niet als de belangrijkste stemmentrekker ervaren. (De drie lokale lijsten die hierop een uitzondering vormden hadden overigens, blijkens de mondelinge enquête, een verkiezingsprogramma dat hoogstens één pagina besloeg.)

\section{Rolopvatting}

Een derde indicatie voor het type binding tussen kiezers en gekozenen vormt de rolopvatting van de politicus. In het vorige hoofdstuk is aangeduid dat veel lijsttrekkers van lokale lijsten als motief voor deelname aan de verkiezingen opgeven dat zij individuele burgers wilden helpen, dan wel de belangen van bepaalde groepen of gemeenschappen wilden behartigen.

Meer expliciet is deze rolopvatting met behulp van de mondelinge enquête gemeten door aan de respondenten dezelfde stelling voor te leggen die ook in het eerder aangehaalde kiezersonderzoek in Echt is gebruikt. Het betreft de opvatting dat raadsleden als belangrijkste funktie een soort ombudsman-rol zouden moeten vervullen.

Uit tabel 5.10 is af te lezen dat driekwart van de lijsttrekkers van lokale politieke groeperingen het eens was met deze stelling. Deze rolopvatting van raadsleden werd in beduidend mindere mate onderschreven binnen de landelijke partijen.

\section{Contacten met burgers}

Een laatste aanwijzing voor het belang van de persoonlijke band tussen kiezers en gekozenen vormt de respons op de volgende vraag, (die uitsluitend aan de 76 in 1982 als raadslid verkozen respondenten is gesteld): "Werd u in de periode 1982-1986 vaak, soms, zelden of niet benaderd door burgers of groepen burgers die aan u als raadslid (of wethouder) hun problemen of verlangens kenbaar maakten?"

Zowel voor landelijke als voor lokale lijsten geldt dat er over het algemeen, althans volgens de opgave van de respondenten, zeer frequent contacten met burgers plaatsvonden. (Zie tabel 5.11.) De verschillen tussen beide categorieën zijn dan ook niet significant.

\section{d. Samenvatting}

Uit de drie onderdelen van deze paragraaf, de analyse van de hoeveelheid voorkeurstemmen, resultaten van kiezersonderzoek en gegevens verkregen door middel van de lijsttrekkersenquêtes, komt het beeld naar voren van een sterk persoonlijke band tussen kiezers en gekozenen in de Limburgse lokale politiek in de jaren tachtig. Het 
lijkt erop dat bij gemeenteraadsverkiezingen veel kiezers eerder kiezen voor een persoon dan voor een partij of een programma.

Naast dit persoonsgebonden stemmen, klinkt vaak het element van persoonlijke dienstverlening door. Onder andere dankzij daadwerkelijke ondersteuning van burgers, alsmede het verkrijgen van de reputatie van effectief dienstverlener, ontstaat een kring van kiezers rondom een politicus. De politicus doet er alles aan, zowel tijdens de verkiezingscampagne als in het gemeenschapsleven, om de persoonlijke band met zoveel mogelijk burgers te verkrijgen en te behouden. Naast de factor dienstverlening wordt in dit verband ook de persoonlijke bekendheid van de politicus door zowel veel kiezers als veel lijsttrekkers als een belangrijk stemmotief aangeduid.

Het bovenstaande gaat in het bijzonder op voor de band tussen kiezers en gekozenen van het CDA en de lokale lijsten. Bij de overige landelijke lijsten zijn deze kenmerken in beduidend mindere mate voorhanden. Toch zijn er ook bij deze categorie lijsten enkele indicaties die wijzen op het voorhanden zijn van sterke persoonlijke bindingen. In dat verband kan onder andere gewezen worden op de verschillen tussen percentages voorkeurstemmen voor deze partijen tussen Limburg en de rest van het land.

\subsection{Achtergronden van de band tussen kiezers en politici in Limburg}

In de inleiding bij dit hoofdstuk is aangegeven dat het onderzoek naar de in de Limburgse lokale politiek in de jaren tachtig voorhanden zijnde typen binding tussen kiezers en politici met name gericht is op twee kenmerken, namelijk de mate waarin sprake is van een persoonlijke en van een instrumentele band. Gemakshalve kan daartoe schema 5.1 worden gehanteerd. Daarbij geldt uiteraard voor beide begrippen de kanttekening dat sprake is van continua tussen twee ideaaltypische polen.

Schema 5.1. Vormen van binding tussen kiezers en gekozenen

niet-instrumenteel instrumenteel

\begin{tabular}{lll} 
onpersoonlijk & A & B \\
persoonlijk & C & D \\
\hline
\end{tabular}

De meer onpersoonlijke vormen van binding, A en B, veronderstellen een zekere mate van identificatie met een bepaalde partij of politieke stroming. Aan die identificatie kan overigens zowel een beleidsoriëntatie ten grondslag liggen, gericht op het politieke programma van de betreffende groepering, als een gevoel van verbondenheid vanwege bijvoorbeeld het karakter van de groepering of het gedrag van de nationale partij met hetzelfde label als de plaatselijke groepering waarop men een stem uitbrengt.

Bij het $\mathrm{C}$-type passen de vormen van politieke loyaliteit tussen kiezers en gekozenen met een persoonlijk karakter. In de lokale omgeving is daarbij onder andere te denken aan familie- en vriendschapsbanden, gezamenlijk lidmaatschap van bepaalde vereni- 
gingen of het feit dat kiezer en gekozene bij elkaar in de straat wonen; kortom persoonlijke bekendheid met en waardering voor de persoon van de politicus. Bij het D-type is met name ook het concept cliëntelisme te plaatsen.

De resultaten van het in de vorige paragraaf beschreven onderzoek duiden erop dat de cliëntelistisch getinte bindingsvorm het sterkst naar voren komt bij de lokale lijsten en daamaast ook bij het CDA. Het belang van dienstverlening indiceert een tamelijk instrumenteel karakter van de relatie tussen kiezers en gekozenen van deze groeperingen. Bij de andere landelijke partijen, met name bij PvdA en VVD, zien wij dat onpersoonlijke stemmotieven, zoals de nationale politieke verhoudingen, een belangrijker rol spelen dan bij de hierboven genoemde lijsten. De persoonlijke binding tussen kiezers en gekozenen lijkt bij deze partijen minder dominant. Bovendien zijn de betreffende politici ook minder geneigd om te beantwoorden aan de rolverwachtingen die passen bij de cliëntelistische relatie.

Gelet op deze resultaten is het wenselijk om nader stil te staan bij het concept cliëntelisme, alvorens in te gaan op de achtergronden ervan.

\section{Het begrip cliëntelisme}

Het begrip cliëntelisme werd in politicologische studies aanvankelijk gehanteerd in situaties waarin sprake was van een persoonlijke en direkte band tussen een politicus (patroon) en een burger (cliënt), waarbij de burger in ruil voor bepaalde - door de patroon verstrekte - goederen en/of diensten, op deze patroon zijn stem uitbrengt (bv. Scott, 1972). Deze definitie vormde een politicologische toespitsing van het ruimere begrip cliëntelisme zoals dat werd gehanteerd in antropologische studies naar afhankelijkheidsrelaties tussen patronen en cliënten in kleine rurale gemeenschappen (Graziano, 1976:149).

Deze 'klassieke' definitie van cliëntelisme werd in de loop der tijd door verschillende onderzoekers opgerekt en van toepassing verklaard op bepaalde typen binding tussen (groepen van) burgers, politieke partijen en de overheidsbureaucratie in 'moderne' democratieën. (Zie onder andere: Sayari, 1977; Belloni, Caciagli en Mattina, 1979; Donneur en Padioleau, 1982; Chubb, 1983; Rooduijn, 1986). Cliëntelisme werd niet langer gezien als een sociaal en politiek verschijnsel dat met de 'modemisering' van de samenleving tot verdwijnen gedoemd is. Zuckerman constateent in dit verband dat:

"Increasing numbers of studies indicate... that clientelism is limited neither to a geographic area nor to a 'stage' in the process of modemisation. Rather, it appears that socio-economic change serves to alter the particular bases of clientele relationships though they persist as frequently found modes of social cohesion" (Zuckerman, 1977:63).

De 'modemisering' van een samenleving lijkt vooral een wijziging te veroorzaken van de 'prijzen' die politici aan burgers te bieden hebben. $\mathrm{Zo}$ is een verschuiving van direkte materiële goederen, (de verharding van een landweg, straatlantaarns, een woningwetwoning, een subsidie enzovoort), naar een ander soort dienstverlening door verschillende onderzoeken zichtbaar gemaakt (vgl. Boissevain, 1977; Komito, 1984). 
De opbrengsten die in westerse democratieën door burgers nagestreefd worden zijn bijvoorbeeld informatie over bureaucratische procedures en regels, ondersteuning bij het invullen van formulieren en bij het aanvragen van vergunningen en subsidies en toegang tot de betreffende ambtenaar. De politicus krijgt in die situatie de rol van makelaar of middelman ('broker') tussen de burgers en een steeds complexer opererende overheidsbureaucratie.

Deze veelheid van verschijningsvormen - Poggi sprak in dit verband van een "sheer ubiquitousness of the clientelist phenomenon" (Poggi, 1983:662) - roept de vraag op wat het meest wezenlijke van cliëntelisme is, en op welke wijze het kan worden onderscheiden van andere soorten relaties tussen burgers en politici. In verschillende theoretische bijdragen over cliëntelisme komt een aantal kenmerken van dit soort relaties naar voren. Als eerste - volgens Graziano meest wezenlijke - verbindende kenmerk, noemen wij het feit dat een cliëntelistische relatie gepaard gaat met een ruilproces:

"There is one element which unifies all the aspects - social as well as political, 'traditional' and 'modern' - of the clientelistic phenomenon: exchange. Clientelism as an interpersonal relationship and clientelism as party-directed patronage are both based on the direct exchange of favors" (Graziano, 1976:157).

Ook bij Eisenstadt en Roniger neemt het element van ruil een belangrijke plaats in bij de conceptuele afbakening van cliëntelisme:

"The interaction on which these relations are based is characterised by the simultaneous exchange of different types of resources - above all, instrumental and economic as well as political ones (support, loyalty, votes, protection) on the one hand, and promises of reciprocity, solidarity and loyalty on the other" (Eisenstadt en Roniger, 1984:49).

Het transactionele of instrumentele karakter van de relatie kan met name worden afgezet tegenover relaties die een doel in zichzelf vonmen. In dit laatste type relaties is sprake van wat Waterbury noemt een sterke 'affective content' (Waterbury, 1977:330). Bailey maakt een vergelijkbaar onderscheid tussen relaties met een morele basis en relaties met een contract-basis (Bailey, 1977:28). In het laatste geval worden de deelnemers primair gemotiveerd door een berekening van persoonlijke kosten en baten. In het eerste geval komt de binding voort uit bijvoorbeeld bepaalde groepssenimenten, persoonlijke vriendschap of ideologische overwegingen.

Graziano, tenslotte, haalt het Weberiaanse begrippenpaar 'wertrational' versus 'zweckrational' aan om de twee typen relaties van elkaar te onderscheiden (Graziano, 1976:159). Hij betoogt dat de cliëntelistische relatie een typisch 'zweckrational' karakter heeft.

Het bovenstaande suggereert een duidelijke theoretische tweedeling in typen binding. De cliëntelistische binding wordt daarbij gekenmerkt door de ruil-relatie met bijbehorende contractuele basis. Het alternatieve bindingstype, voorlopig als nietcliëntelistisch aangeduid, heeft dan een morele of ideële basis. In de praktijk levert deze dichotomie echter problemen op en moet het hier genoemde, als wezenlijk beschouwde kenmerk van cliëntelisme enigszins genuanceerd worden. 
In de eerste plaats kunnen beide hiervoor onderscheiden typen binding tegelijk voorkomen. Een hoge mate van 'affective content' van de binding sluit het voortbestaan van een sterk transactioneel element geenszins uit. Zo kan bijvoorbeeld de keuze van de politieke partij door de kiezer gemaakt worden op grond van groepsgebondenheid, traditie en dergelijke, terwijl de keuze van een bepaalde kandidaat binnen die partij, bepaald wordt door meer transactionele overwegingen. Bax' beschrijving van de Ierse situatie vormt daarvan een illustratie (Bax, 1976; zie voorts: Parker, 1984).

In de tweede plaats kan een oorspronkelijk instrumentele relatie na verloop van tijd een morele lading krijgen. Dit hangt onder meer samen met het diffuse karakter van de geruilde goederen en diensten en de onbepaalde tijdsduur van de binding. Eisenstadt en Roniger wijzen erop dat als gevolg hiervan sprake kan zijn van:

"..a strong element of interpersonal obligation that is prevalent in these relations even if these relations are often very ambivalent" (Eisenstadt en Roniger, 1984:48).

Ook Graziano besteedt aandacht aan dit element. Hij stelt onder andere dat cliëntelistische relaties mede daarom verschillen van de puur instrumentele economische contract-situatie omdat:

"In social exchange, reciprocation for benefits received is assured by the feelings of personal obligation, gratitude and trust engendered by the very interaction" (Graziano, 1976:60).

De cliëntelistische relatie, die weliswaar gebaseerd is op direkte ruil, wordt volgens hem vaak verder versterkt door het feit dat de patroon zich ontwikkelt tot een voor de gтоep en voor de individuele cliënt gelegitimeerde autoriteit. Silverman gaat nog een stap verder en maakt een onderscheid tussen cliëntelisme blijkend uit 'real exchange' en cliëntelisme als een 'way of cognitive patterning', een set van verwachtingen van cliënten gebaseerd op wat hij de 'mythe van de patronage' noemt (Silverman, 1977). Bax wijst er eveneens op dat het voor de aard van de relatie tussen kiezer en gekozene niet uitmaakt of de kiezer inderdaad bepaalde directe beloningen ontvangt voor zijn politieke steun.

"To attract voters implies doing favours for them, or anyway, to let them think that favours are done or can be done" (Bax, 1976:49).

Met andere woorden, ook een reputatie van effectief dienstbetoon in het geval dat dat nodig mocht zijn, kan voor kiezers voldoende aanleiding vormen om te stemmen op een bepaalde politicus.

Aangezien een dergelijke basis de binding van de kiezer niet bijzonder sterk maakt - indien een ander met succes kan suggereren dat hij een betere dienstverlener is zullen de kiezers naar hem overlopen - zal de politicus er van nature op uit zijn om de niet-transactionele elementen in de relatie te versterken. In dat geval vervagen echter de grenzen tussen 'contract-based'- en 'moral-based'-relaties.

Als een tweede, voor cliëntelistische relaties typerend kenmerk wordt de grote (machts)ongelijkheid tussen patroon en cliënt genoemd. De cliënt is afhankelijk van de patroon voor het verkrijgen van voor hem belangrijke goederen en/of diensten. De 
patroon bezit een quasi-monopolie op de toegang tot deze schaarse zaken. De patrooncliënt-relatie is 'vertikaall' van aard en ondermijnt mogelijke 'horizontale' bindingen en solidariteit, met name tussen cliënten onderling (Eisenstadt en Roniger, 1984:49). In een marxistisch getinte benadering wordt cliëntelisme dan ook wel voorgesteld als een effectieve uitbuitingsstrategie (Scott, 1977). Ook dit kenmerk van cliëntelisme heeft echter een gradueel karakter, zodat enige nuancering gewenst is.

Waterbury wijst er op dat zowel de afhankelijkheid van de cliënt als het monopolie van de patroon niet absoluut zijn in het 'moderne' cliëntelisme. De eerder aangehaalde Ierse studies bevestigen het beeld van verschillende patroons - door Bax aangeduid als 'makelaars' ('brokers') - die elkaar beconcurreren om de steun van de cliënten (Waterbury, 1977:329; Bax, 1976:50). In zo'n situatie is er wel sprake van ongelijkheid, maar niet van volstrekte persoonlijke afhankelijkheid van cliënten. Bij de cliëntelistische band tussen kiezers en gekozenen geldt bovendien dat de kiezer alleen al door het feit dat de stemming geheim is, een grote mate van autonomie behoudt.

Een derde kenmerk dat cliëntelisme zou kunnen onderscheiden van een aantal andere relatievormen is het persoonlijke karakter ervan. Zowel economische marktrelaties als burocratische relaties zijn in principe onpersoonlijk van karakter. Dat geldt ook voor bindingen tussen burgers en politieke partijen voor zover die gebaseerd zijn op onpersoonlijke factoren als instemming met de ideologie en standpunten van de partij of traditie en saamhorigheidsgevoel. Cliëntelisme zou juist wel uitsluitend gebaseerd zijn op een persoonlijke binding tussen burger en politicus.

Ook ten aanzien van dit aspect moet geconcludeerd worden dat de grenzen met name aan de kant van de cliënt niet altijd even scherp te trekken zijn. De cliënt kan immers deel uitmaken van een groep (bijvoorbeeld vakbond of dorpsgemeenschap) die als zodanig een cliëntelistische (ruil-)relatie onderhoudt met een bepaalde politicus. De band tussen cliënt en patroon loopt in dat geval via de betreffende groep. Er is dan sprake van wat genoemd zou kunnen worden 'groepscliëntelisme'. Om het concept cliëntelisme toch nog enig onderscheidend vermogen te laten behouden, zal in deze studie deze groepsvariant echter buiten de definitie worden gelaten.

Een cliëntelistische relatie tussen kiezer en gekozene kan, samengevat, daaraan herkend worden dat ze een primair instrumenteel en persoonlijk karakter heeft en is gebaseerd op de al dan niet reële capaciteit van de politicus om aan de kiezer persoonlijk bepaalde voordelen te verschaffen.

\section{Achtergronden van het cliëntelisme in Limburg}

De opmerkelijke omvang en persistentie van het cliëntelisme in verschillende omgevingen, waaronder de Limburgse, roept de vraag op naar de oorzaken en achtergronden van dit verschijnsel. Enkele in de theorievorming rond cliëntelisme gesuggereerde verklaringen kunnen in verband worden gebracht met de Limburgse situatie. Deze verklaringen hebben zowel betrekking op het niveau van de sociaal-economische en culturele omgeving waarbinnen de politieke verhoudingen gestalte krijgen, als op het niveau van de individuele kiezers en politici. 
Het feit dat cliëntelistische verhoudingen oorspronkelijk primair vanuit een antropologische gezichtshoek werd bestudeerd wekt wellicht de suggestie dat dit verschijnsel verbonden is aan in sociaal-economisch opzicht achtergebleven samenlevingen. Ook binnen Europa zijn studies die zich met cliëntelistische relaties bezig houden geconcentreerd op minder ontwikkelde regio's als het Ierse platteland en Zuid-Italië. De provincie Limburg behoort echter niet tot deze categorie. Enkele andere kenmerken van deze provincie komen echter wel overeen met kenmerken van de genoemde Europese regio's.

Meest in het oog springend is de combinatie tussen cliëntelisme en katholicisme. Boissevain suggereert het bestaan van een meer dan toevallige congruentie tussen het in de Rooms-Katholieke dogmatiek gewortelde beeld van de middelaar in de persoon van de priester die bemiddelt tussen God en de gelovigen, en de cliëntelistische situatie met de politicus als middelaar tussen overheid en burgers (Boissevain, 1977). ${ }^{5}$

Een andere aspect van de omgeving dat een rol kan spelen, is de perifere ligging van de betreffende politieke systemen ten opzichte van het politiek-bestuurlijke centrum. Gebrekkige integratie van bepaalde regio's en de onwil van de bewoners daarvan om zich met het centrum te identificeren, zijn bevorderlijk voor een cliëntelistische vorm van belangenbehartiging. In de woorden van Bax: "Brokerage militates against integration." (Bax, 1976:52) Dit geldt overigens ook voor gemeenschappen die in ander dan geografisch opzicht een perifere positie innemen, zoals ethnische minderheden (Hamilton, 1979) en personen die uit andere delen van het land komen (Günes-Ayata, 1987). Deze perifere ligging geldt ook voor Limburg, in zowel geografisch als cultureel opzicht. (Zie hierover hoofdstuk 2.)

Een eenmaal gevestigde traditie van cliëntelisme zal in de praktijk moeilijk te doorbreken zijn. Politici, afhankelijk als zij zijn van de gunst van de kiezers, hebben weinig mogelijkheden uit zichzelf de behoeften van hun electoraat, het vervullen van een makelaarsrol, te wijzigen, zeker niet als er nog concurrenten overblijven die wel bereid zijn om aan die behoefte te voldoen. Wat dat betreft zijn zij, evenals aanbieders in de marktsituatie, in hoge mate gevangenen van het systeem. Toch is een cliëntelistische band met de kiezer voor hen op zich niet erg aantrekkelijk.

Een belangrijk probleem voor de cliëntelistische politicus is dat hij er constant aan moet werken om zijn cliëntennetwerk in stand te houden, hetgeen in de regel nogal wat offers vergt (Bax, 1976:88). Dit geldt overigens alleen wanneer er een tamelijk lage drempel voor nieuwe aanbieders van dienstverlening op de lokale politieke markt bestaat. In de Limburgse situatie is het aannemelijk dat dit in de regel het geval is geweest. De in het vorige hoofdstuk aangehaalde case-studies wijzen hier althans op. Wanneer het electoraat, zoals in Limburg, in politiek-ideologisch opzicht onverdeeld is zijn politici echter bij gebrek aan alternatief goeddeels aangewezen op individuele belangenbehartiging als middel om de kiezers aan zich te binden (Bax, 1976:52). Het kan in zo'n situatie de meest rationele strategie zijn om politiek leiderschap te verwerven en succesvol te concurreren met politieke rivalen. (Zie ook Günes-Ayata,

5 Het lijkt in dit verband geen toeval dat de vele studies naar cliëntelisme in de politiek gericht zijn op primair katholieke gebieden. 
1987.) Dit geldt met name indien de betreffende politicus in staat is om een sterke positie op te bouwen binnen groepen kiezers waar hij zelf deel van uitmaakt (zoals een vereniging, een kerkdorp of buurt). Een groot aantal Limburgse politici verwierf op deze wijze een als het ware natuurlijke achterban, die voor de concurrentie moeilijk bereikbaar was.

Cliëntelistische betrekkingen zijn echter niet alleen afhankelijk van de al dan niet vrije keuze van politici om zich als dienstverlener te profileren. $\mathrm{Bij}$ de kiezers moet ook een op zijn minst potentiële behoefte aan dergelijke vormen van dienstverlening bestaan.

In de vorige paragraaf is er op gewezen dat zich een verschuiving heeft voorgedaan van de 'prijzen' die politici aan burgers kunnen bieden. De baten van het moderne cliëntelisme hebben vooral met informatie over en toegang tot de overheidsbureaucratie te maken. Wanneer de distributie van goederen en diensten door overheidsbureaucratieën op een door de burgers als volstrekt onpersoonlijk ervaren wijze zou geschieden, en deze bureaucratieën voor allen op gelijke wijze toegankelijk en begrijpelijk zouden opereren ${ }^{6}$, dan zou er waarschijnlijk geen behoefte aan bemiddeling door 'makelaars' bestaan. De praktijk zal echter veelal anders zijn (bv. Knegt, 1987).

Uit het kiezersonderzoek blijkt dat dit laatste motief voor het aangaan van cliëntelistische relaties onder de Limburgse kiezers wel een rol speelt. Er is sprake van behoefte aan dienstverlening onder andere op het gebied van de belastingen, volkshuisvesting (onder andere woningtoewijzing en huursubsidie) en ruimtelijke ordening (met name bouwvergunningen). Van politici wordt in het algemeen een open oor verwacht voor problemen rond het verkrijgen van goederen en diensten van de overheidsbureaucratie en waar nodig informatie-verschaffing en bemiddeling.

Naast dit soort meer concrete baten, menen Eisenstadt en Roniger dat cliëntelistische relaties een als prettig ervaren 'moreel klimaat' met zich mee zou brengen. Het zou leiden tot een vermindering van de spanning tussen een steeds onpersoonlijker en complexer wordende samenleving, met vervreemdend werkende bureaucratieën aan de ene kant, en de behoefte aan persoonlijke relaties, vertrouwen, solidariteit en zingeving aan de andere kant (Eisenstadt en Roniger, 1984). Onduidelijk is in hoeverre dit ook opgaat in de Limburgse situatie.

\section{Veranderingen in de binding tussen kiezers en gekozenen}

Uit verschillende hiervoor aangehaalde studies is naar voren gekomen dat cliëntelisme niet zonder meer als een in belang afnemend overblijfsel van archaïsche maatschappelijke verhoudingen kan worden beschouwd. Traditionele vormen van cliëntelisme als de patronage-relatie tussen boer en landeigenaar verdwijnen weliswaar, maar in de gedaante van de politicus als makelaar, eventueel ten behoeve van hele categorieën kiezers, kan het cliëntelisme ook in 'moderne' politieke systemen voortbestaan.

Huntington en Dominguez veronderstellen een ontwikkeling in de aard van de binding tussen kiezers en gekozenen, (in termen van het hier ontwikkelde schema),

6 Naar analogie van het begrip 'volkomen concurrentie' voor een perfekte marktwerking zou men hier wellicht van 'volkomen burocratie' kunnen spreken. 
van persoonlijk naar onpersoonlijk en van instrumenteel naar niet-instrumenteel (Huntington en Dominguez, 1975). Een dergelijke ontwikkeling lijkt zich echter in de Limburgse situatie tot nu toe slechts in beperkte mate te hebben voorgedaan.

Het aantal persoonlijke voorkeurstemmen is eerder gestegen dan gedaald. Het instrumentele en in ieder geval het persoonlijke element in de binding wordt door politieke partijen, zij het niet in gelijke mate, nog steeds bewust benadrukt, onder andere gedurende de verkiezingscampagnes. Het is bovendien niet te verwachten dat de lokale lijsten, die zich van oudsher het sterkst op deze elementen hebben geprofileerd hun opstelling zullen wijzigen.

Met name het CDA zou zich kunnen ontwikkelen tot een in hoge mate cliëntelistische partij, analoog aan christen-democratische partijen in bijvoorbeeld België en Italië. De attitude van de plaatselijke leiders van deze partij staat blijkens de enquête het dichtst bij het cliëntelistische 'ethos'. Ook haar aanhang lijkt in mindere mate ideologisch gemotiveerd te zijn. De partij verkeert bovendien zowel provinciaal als landelijk in het begin van de jaren negentig in een tamelijk machtige positie zodat gebruikmaking van boven-lokale relaties voor CDA-politici een belangrijk en effectief middel zou kunnen zijn om de reputatie van succesvol dienstverlener te vergroten.

Onduidelijk is in hoeverre lokale CDA-politici zich, onder invloed van de nationale partij, in de komende tijd ook in de kleine gemeenten ideologisch en politiek-inhoudelijk sterker gaan profileren. Een dergelijke houding zou de neiging tot cliëntelisme kunnen afremmen. In het zicht van de nog altijd vrij sterke concurrentie van lokale lijsten is een meer ideologische profilering echter wellicht electoraal gezien onaantrekkelijk. Een tendens in omgekeerde richting bij de overige landelijke partijen is mede gelet op deze electorale overwegingen evenmin ondenkbaar.

De nationalisering van de Limburgse lokale politiek lijkt vooralsnog niet tot een substantiële verzwakking van het cliëntelisme te leiden. Een ondubbelzinnige, ideologisch gemotiveerde afwijzing van cliëntelisme is bij geen van de partijen duidelijk voorhanden. De komst van politieke partijen opent daarentegen juist nieuwe mogelijkheden voor nog effectievere vormen van dienstverlening door lokale politici, gelet op de dwarsverbanden binnen deze partijen tussen de lokale, provinciale, nationale en Europese niveaus. Het lijkt gegeven de gevestigde politieke cultuur niet waarschijnlijk dat die mogelijkheden geheel onbenut zullen blijven. 



\section{Hoofdstuk 6}

\section{Recrutering van politieke leiders}

\subsection{Inleiding}

$\mathrm{Na}$ de behandeling van de organisatie en het functioneren van lokale lijsten en de aard van de binding tussen kiezers en gekozenen, richten wij ons in dit hoofdstuk op de kenmerken van de plaatselijke politieke leiders in relatie tot de wijze van recrutering. Het proces van recrutering van politici kan zowel vanuit het perspectief van de individuele politicus beschouwd worden, als vanuit de instellingen, politieke organisaties en personen die belast zijn met recrutering. Tijdens dit proces is er sprake van zowel zelfselectie, als selectie door anderen. In zijn klassieke studie naar recrutering in de lokale politiek in de San Fransisco Bay Area, drukte Prewitt deze twee afzonderlijke ingangen om recrutering te bestuderen als volgt uit:

"One approach to studying leadership selection seeks to identify the processes channeling political aspirations. A second and, as it turns out, closely related approach is to identify the processes mobilizing talent and resources to public office. Very frequently these two approaches overtap in the social processes identified. (Prewitt, 1970:10-11)

De meest voor de hand liggende instituties waarbinnen recrutering voor politieke ambten zich afspeelt zijn politieke partijen. Normaal gesproken treden zij op als (wat Czudnowski heeft genoemd) 'recruitment agencies'. Bestuursleden, zittende raadsleden, leden van speciale selectie-commissies en tot slot de partij-leden, vormen daarbinnen de belangrijkste 'recruitment agents' (Czudnowkski, 1975). (Als Nederlandstalige equivalenten worden hier de termen 'recruteringsinstanties' en 'selectie-functionarissen' gehanteerd.)

Bij selectie in het kader van politieke partijen is de kring van kandidaten in principe logisch beperkt tot leden (en eventueel potentiële leden) van die partijen. Het simpele lidmaatschap is echter uiteraard niet voldoende om in aanmerking te komen voor kandidaatstelling. Kandidaten moeten zich in de regel binnen de partij op een dusdanige manier manifesteren dat een voldoende mate van persoonlijke en (afhankelijk van het type partij) ideologische identificatie tussen hen en de verschillende selectie-functionarissen op kan treden.

De partijen hoeven echter bij de uitvoering van hun recruteringsfunctie niet uitsluitend intern georiënteerd te zijn. Afhankelijk van de aard van de partij kan het 
voorkomen dat bij de selectie van kandidaten in het bijzonder gelet wordt op de aanvaardbaarheid van deze personen voor bepaalde verenigingen of organisaties, zoals een vakbond. In dat geval kan de elite van dergelijke organisaties tot op zekere hoogte beschouwd worden als (mede-)recruteringsinstantie. ${ }^{1}$

Bij de afwezigheid van politieke organisaties met een organisatie-structuur die zoals in hoofdstuk 4 bleek - typerend is voor plaatselijke afdelingen van landelijke partijen, moet de recrutering op een andere wijze plaats vinden.

Een lokale lijst kan in meerdere of mindere mate geënt zijn op een bepaalde organisatie binnen de plaatselijke gemeenschap. Dit geldt met name voor de sociaaleconomische (stands)lijsten en de culturele (verenigings)lijsten. In dat geval treedt de groepselite op als recruteringsinstantie. De recrutering zal echter in vergelijking met de selectie bij politieke partijen een informeler karakter hebben.

Dit geldt a fortiori voor die situaties waarin lokale lijsten betrekkelijk onafhankelijk van verenigingen en organisaties opereren. Hierbij kan gedacht worden aan de territoriale lijsten en de persoonslijsten. In dat geval zal het veelal de lijsttrekker zelf zijn die kandidaten en een eventuele opvolger uitzoekt.

Voor beide situaties is het echter te verwachten dat, evenals uit het onderzoek van Prewitt naar voren komt, het verenigingsleven in ruime zin - de verschillende plaatselijke organen als school- en kerkbesturen daar tevens toegerekend - het vacuüm opvult dat ontstaat door de afwezigheid van politieke partijen als recruteringsinstanties. Prewitt verwoordde deze belangrijke functie van het verenigingsleven als volgt:

"Political activity is a subset of more general social activity; elected position is an extension of volunteer type of community roles in organisations... There is an overlap between the politically active stratum and organized civic life. It is to be expected, therefore, that a community's many organizations and associations are a breeding ground for political officialdom.... It is also likely that persons with council ambitions recognize that civic groups are a useful springboard into elected office; the civic role is chosen to attain other goals" (Prewitt, 1970:85-86).

De selectie door anderen leidt er daarnaast in het algemeen toe dat er een zekere homogeniteit ontstaat binnen de politieke elite voor wat betreft een aantal kenmerken van de politieke actoren. Het is aannemelijk dat de elite van recruteringsinstanties enkele kenmerken gemeen heeft met de door hen uitverkoren kandidaten, met name als het gaat om sociaal-economische status. Naar gelang van de aard van de organisatie geldt dat tevens voor kenmerken als geslacht, leeftijd en herkomst, afhankelijk van het belang dat de selectie-functionarissen aan deze overige eigenschappen hechten. Prewitt drukte dit verschijnsel als volgt uit:

"Persons who control the pathways to public office tend to perpetuate their own kind" (Prewitt, 1970:27).

1 In dit verband kan bijvoorbeeld gedacht worden aan de kwaliteitszetels die de KVP op allerlei niveau's aan verwante organisaties ter beschikking stelde, (Duffhues c.s., 1985:205 e.v.; Boogers en Keizers, 1991). 
Hillebrand wees ter verklaring hiervan op het sociaal-psychologische fenomeen van de 'ingroup-outgroup-differentiatie', inhoudende dat over de eigen groep positiever wordt gedacht dan over andere groepen, met name wanneer er sprake is van een concurrentieverhouding, zoals bij kandidaatstelling het geval is (Hillebrand, 1992:245). Wat kan dit betekenen voor de te verwachten kenmerken van lijsttrekkers van landelijke, dan wel lokale lijsten in de Limburgse lokale politiek? Is aan de lokale lijst - die onder andere gekenmerkt wordt door een lage organisatiegraad - een ander recruteringspatroon verbonden dan aan de plaatselijke afdeling van een landelijke partij? Geeft mede daarom in deze lijsten een ander type politicus de toon aan dan in de landelijke lijsten of leveren beide soorten lijsten eenzelfde type lijsttrekker op? Vormt de in het vorige hoofdstuk vastgestelde cliëntelistisch getinte binding tussen kiezers en gekozenen een hindernis voor bepaalde bevolkingsgroepen om politieke ambten te gaan bekleden? Deze vragen staan centraal in dit hoofdstuk.

De empirische gegevens inzake het recruteringsproces in de Limburgse lokale politiek zijn echter helaas tamelijk beperkt. Een indirekte aanwijzing levert het profiel van de lijsttrekkers op, zoals dat uit de mondelinge lijsttrekkersenquête naar voren is gekomen. De kenmerken van deze plaatselijke politici geven een beeld van die eigenschappen die kennelijk de kans op zelf-selectie dan wel selectie door anderen vergroten. Dit beeld wordt aangescherpt door meer specifiek op de wijze van recrutering betrekking hebbende gegevens die met behulp van de schriftelijke lijsttrekkersenquête verzameld zijn. In de tweede paragraaf worden deze onderzoeksresultaten beschreven.

In de derde paragraaf gaan wij vervolgens nader in op de achtergronden van deze resulaten en op de vraag welke wijzigingen ten gevolge van het eerder beschreven nationaliseringsproces op dit punt te verwachten zijn.

\subsection{Beschrijving van de onderzoeksresultaten}

Met betrekking tot het thema van de recrutering is het noodzakelijk om rekening te houden met het feit dat een aantal respondenten van landelijke lijsten bij hun initiële kandidaatstelling via lokale politieke groeperingen zijn gerecruteerd. Dit geldt in het bijzonder voor bijna alle geïnterviewde lijsttrekkers van het CDA, (zie paragraaf 4.3). Dit is de reden waarom de respondenten van landelijke lijsten bij de volgende presentatie van enquête-resultaten regelmatig naar partij worden uitgesplitst, of wel worden ingedeeld in de categorieën CDA en overige landelijke partijen. ${ }^{2}$

2 Een systematische samenhang van de onderzochte kenmerken met de gemeentegrootte van de gemeenten waarin de respondenten woonden, bleek niet aanwezig. Vandaar dat ook in deze sub-paragraaf de respondenten uitsluitend naar type lijst worden gerubriceetd. 


\section{a. Kenmerken van lijsttrekkers}

Een eerste indicatie voor de aard van het recruteringsproces levert, zoals hiervoor gesteld, het overzicht van kenmerken van lijsttrekkers op. De in de enquête opgenomen kenmerken waren achtereenvolgens; het geslacht, de leeftijd, de geografische herkomst, de genoten opleiding en het beroep dat wordt (of werd) uitgeoefend, familiebanden met andere (lokale) politici, verenigingsactiviteiten en tenslotte de mate van kerkelijkheid en kerksheid van de respondenten. Bij de kenmerken geslacht en leeftijd wordt de analyse verbreed tot de Limburgse raadsleden in 1982 en 1986.

\section{Geslacht}

Onder de achtennegentig geïnterviewde lijsttrekkers, bevonden zich slechts drie vrouwen, twee van een landelijke en één van een lokale lijst. Een aanwijzing voor de werking van specifiek aan de Limburgse omgeving gebonden faktoren, vormt het feit dat het aantal vrouwelijke raadsleden en wethouders in deze provincie aanmerkelijk lager is dan in andere delen van het land. Voor de gemeenteraadsleden is de situatie na de verkiezingen van 1982 en 1986, (de periode waarop de lijsttrekkersenquête betrekking heeft), in tabel 6.1 weergegeven.

In beide verkiezingsjaren bleef het percentage vrouwelijke raadsleden in de provincie Limburg ver achter bij de cijfers in de andere provincies. Ook het aantal vrouwelijke wethouders was in Limburg relatief laag met circa 5, respectievelijk 10 procent in 1982 en 1986. De landelijke cijfers in de zelfde jaren bedroegen circa 9 en 13 procent van het totaal aantal wethouders.

Bij een differentiatie naar type lijst blijken zich enkele opvallende verschillen voor te doen. In tabel 6.2 is het percentage vrouwelijke raadsleden per partij in Limburg en in de rest van Nederland met elkaar vergeleken.

Uit deze tabel blijkt dat vrouwelijke raadsleden die in 1982 en 1986 via lokale lijsten in de gemeenteraad werden verkozen tamelijk zeldzaam waren. Vrouwen verwierven in beide verkiezingsjaren relatief meer zetels bij landelijke lijsten dan bij lokale lijsten. Van de landelijke lijsten kende het CDA in beide verkiezingsjaren het geringste percentage vrouwelijke raadsleden. De PvdA scoorde op dit punt het hoogst.

Voor alle Limburgse landelijke lijsten gold overigens dat er relatief beduidend minder vrouwen in de diverse gemeenteraden werden verkozen dan in de rest van het land. De sterkste afwijking deed zich voor bij de kleine linkse lijsten.

\section{Leeftijd}

Op het punt van de leeftijd van de lijsttrekker bestaan er aanzienlijke verschillen tussen lokale en landelijke lijsten. Tabel 6.3 geeft hiervan een overzicht. Daarbij is de leeftijd van de respondenten in het verkiezingsjaar 1982 weergegeven. ${ }^{3}$

3 Het significantie-niveau van het verschil tussen respondenten van landelijke en lokale lijsten is in deze en de volgende tabellen steeds aangegeven. Voor de nadere uitsplitsing van landelijke partijen geldt echter dat de celfrequenties te gering zijn om daarover aan de hand van de chi ${ }^{2}$-toets uitsluitsel te kunnen geven. 
Tabel 6.1. Aantal in 1982 en 1986 verkozen vrouwelijke gemeenteraadsleden als percentage van het totaal, per provincie.

\begin{tabular}{lcc}
\hline & 1982 & 1986 \\
\hline Groningen & 19,4 & 19,2 \\
Friesland & 16,4 & 21,8 \\
Drenthe & 16,9 & 21,1 \\
Overijssel & 15,1 & 18,2 \\
Gelderland & 13,7 & 16,8 \\
Utrecht & 17,6 & 23,1 \\
Flevoland & & 25,0 \\
Noord-Holland & 21,8 & 25,0 \\
Zuid-Holland & 17,0 & 21,0 \\
Zeeland & 11,0 & 16,1 \\
Noord-Brabant & 13,5 & 16,7 \\
Limburg & 7,9 & 11,4 \\
& & 19,1 \\
Nederland totaal & 15,5 &
\end{tabular}

Bron: CBS, Statistieken der verkiezingen

Tabel 62. Percentage in 1982 en 1986 in Limburg en de rest van Nederland verkozen vrouwelijke gemeenteraadsleden, naar type lijst

\begin{tabular}{|c|c|c|c|c|}
\hline & \multicolumn{2}{|l|}{1982} & \multicolumn{2}{|l|}{1986} \\
\hline & Limburg & $\begin{array}{l}\text { Overig } \\
\text { Nederland }\end{array}$ & Limburg & $\begin{array}{l}\text { Overig } \\
\text { Nederland }\end{array}$ \\
\hline Lokale lijsten & 4,7 & 11,4 & 7,1 & 13,6 \\
\hline Landelijke lijsten** & 11,2 & 18,4 & 14,7 & 22,2 \\
\hline $\mathrm{CDA}$ & 10,3 & 11,8 & 10,8 & 15,9 \\
\hline PvdA & 15,4 & 23,8 & 21,9 & 27,8 \\
\hline VVD & 13.8 & 21,6 & 15.8 & 23,6 \\
\hline Klein Links* & 11,4 & 22,7 & 15,9 & 26,5 \\
\hline Totaal & 7,9 & 16.3 & 11,5 & 20.0 \\
\hline
\end{tabular}

* Klein links = D66, PPR, PSP, CPN en PAK; ** Uitsluitend de in de tabel genoemde partijen. Bron: CBS, Statistieken der verkiezingen

Uit de tabel is op te maken dat bijna de helft van de respondenten van lokale lijsten ouder was dan 50 jaar terwijl slechts 16 procent van de lijsttrekkers van landelijke lijsten in die leeftijdscategorie viel. In de categorie jonger dan 40 jaar was eveneens sprake van een groot contrast. Van de respondenten van landelijke lijsten was 56 
Tabel 6.3. Lijsttrekkers naar leeftijd in 1982 en type lijst.

\begin{tabular}{|c|c|c|c|c|c|c|}
\hline & $21-29$ & $30-39$ & $40-49$ & $50-59$ & $60+$ & Totaal \\
\hline Lokale lijsten & $\begin{array}{l}1 \\
(2 \%)\end{array}$ & $\begin{array}{l}9 \\
(16 \%)\end{array}$ & $\begin{array}{l}18 \\
(33 \%)\end{array}$ & $\begin{array}{l}19 \\
(34 \%)\end{array}$ & $\begin{array}{l}8 \\
(15 \%)\end{array}$ & $\begin{array}{l}55 \\
(100 \%)\end{array}$ \\
\hline Landelijke lijsten & $\begin{array}{l}7 \\
(16 \%)\end{array}$ & $\begin{array}{l}17 \\
(40 \%)\end{array}$ & $\begin{array}{l}12 \\
(28 \%)\end{array}$ & $\begin{array}{l}6 \\
(14 \%)\end{array}$ & $\begin{array}{l}1 \\
(2 \%)\end{array}$ & $\begin{array}{l}43 \\
(100 \%)\end{array}$ \\
\hline \multicolumn{7}{|c|}{$\operatorname{chi}^{2}=19,63 ;(p \leq 0,005)$} \\
\hline $\mathrm{CDA}$ & - & 3 & 3 & 4 & - & 10 \\
\hline PvdA & 2 & 3 & 3 & 1 & - & 9 \\
\hline VVD & - & 6 & 4 & 1 & - & 11 \\
\hline Klein Links & 5 & 5 & 2 & - & 1 & 13 \\
\hline Totaal & $\begin{array}{l}8 \\
(8 \%)\end{array}$ & $\begin{array}{l}26 \\
(27 \%)\end{array}$ & $\begin{array}{l}30 \\
(31 \%)\end{array}$ & $\begin{array}{l}25 \\
(25 \%)\end{array}$ & $\begin{array}{l}9 \\
(9 \%)\end{array}$ & $\begin{array}{l}98 \\
(100 \%)\end{array}$ \\
\hline
\end{tabular}

Bron: Lijsttrekkersenquête, RL

procent jonger dan 40; het vergelijkbare percentage bij de lokale lijsten bedroeg 18 procent.

Een nadere uitsplitsing van de landelijke lijsten laat zien dat het leeftijdspatroon van CDA-lijsttrekkers min of meer vergelijkbaar was met dat van de lokale lijsttrekkers. Het grootste aantal was ouder dan veertig. Vrijwel alle lijsttrekkers jonger dan veertig jaar waren te vinden bij de overige landelijke partijen. Bij die partijen waren de veertig-plussers in de minderheid.

Ook bij dit onderdeel kan de analyse van de kenmerken van politici verbreed worden van lijsttrekkers tot raadsleden van de diverse lijsten. In tabel 6.4 is een overzicht gegeven van de leeftijd van Limburgse raadsleden in respectievelijk 1982 en 1986.

De leeftijdsverschillen tussen raadsleden van lokale en landelijke lijsten blijken minder groot dan die tussen lijsttrekkers van beide typen lijsten, maar de richting van de verschillen is gelijk. Het raadsledenbestand van CDA en lokale lijsten was gemiddeld ouder dan dat van de overige landelijke partijen. In beide verkiezingsjaren vormden bij de PvdA en de kleine linkse partijen de raadsleden die tussen de 30 en 39 jaar waren de grootste categorie. Bij de andere partijen en groeperingen waren relatief meer veertigers en vijftigers vertegenwoordigd.

Het leefiijdspatroon van raadsleden van lokale lijsten bleef in 1986 vrijwel ongewijzigd. Bij het CDA en de PvdA was er in 1986 sprake van een afname van dertigers en een toename van veertigers, zodat er per saldo enige vergrijzing van het raadsledenbestand optrad. De verschillen op dit punt tussen deze partijen bleven echter opvallend groot.

Bij de kleine linkse partijen nam het percentage dertigers en veertigers toe terwijl het percentage twintigers en vijftig-plussers daalde. De ontwikkeling van het leeftijdspatroon van VVD-raadsleden levert een diffuus beeld op. Tegenover een stijging 
Tabel 6.4.a. In 1982 in Limburg verkozen gemeenteraadsleden naar leeftijd en type lijst.

\begin{tabular}{|c|c|c|c|c|c|c|}
\hline & $21-29$ & $30-39$ & $40-49$ & $50-59$ & $60+$ & Totaal \\
\hline Lokale lijsten & $2,8 \%$ & $20,9 \%$ & $32.4 \%$ & $27,9 \%$ & $16.0 \%$ & $\begin{array}{l}100 \% \\
(498)\end{array}$ \\
\hline Landelijke lijsten* & $2,5 \%$ & $29,7 \%$ & $31,7 \%$ & $25,6 \%$ & $10,5 \%$ & $\begin{array}{l}100 \% \\
(549)\end{array}$ \\
\hline $\mathrm{CDA}$ & $1,1 \%$ & $21,7 \%$ & $33,1 \%$ & $30,0 \%$ & $14,0 \%$ & $\begin{array}{l}100 \% \\
(350)\end{array}$ \\
\hline PvdA & $6,2 \%$ & $58,5 \%$ & $23,1 \%$ & $12,3 \%$ & - & $\begin{array}{l}100 \% \\
(87)\end{array}$ \\
\hline VVD & $2,5 \%$ & $31,3 \%$ & $35,0 \%$ & $23,8 \%$ & $7,5 \%$ & $\begin{array}{l}100 \% \\
(80)\end{array}$ \\
\hline Klein Links** & $7,4 \%$ & $46,3 \%$ & $25,9 \%$ & $16,7 \%$ & $3,7 \%$ & $\begin{array}{l}100 \% \\
(32)\end{array}$ \\
\hline Totaal Limburg & $2,7 \%$ & $25,7 \%$ & $31.9 \%$ & $26,6 \%$ & $13,1 \%$ & $\begin{array}{l}100 \% \\
(1.047)\end{array}$ \\
\hline Totaal overig Ned & $3.3 \%$ & $28.1 \%$ & $32,1 \%$ & $26,4 \%$ & $10,1 \%$ & $\begin{array}{l}100 \% \\
(10.741)\end{array}$ \\
\hline
\end{tabular}

Tabel 6.4.b. In 1986 in Limburg verkozen gemeenteraadsleden naar leeftijd en type lijst.

\begin{tabular}{lllllll}
\hline & $21-29$ & $30-39$ & $40-49$ & $50-59$ & $60+$ & Totaal \\
\hline Lokale lijsten & $2,0 \%$ & $20,4 \%$ & $31,2 \%$ & $27,3 \%$ & $19,1 \%$ & $\begin{array}{l}100 \% \\
(480)\end{array}$ \\
Landelijke lijsten* & $3,0 \%$ & $27,4 \%$ & $37,0 \%$ & $22,2 \%$ & $10,4 \%$ & $\begin{array}{l}100 \% \\
(569)\end{array}$ \\
CDA & $2,2 \%$ & $15,2 \%$ & $37,8 \%$ & $30,0 \%$ & $14,9 \%$ & $100 \%$ \\
PvdA & $3,3 \%$ & $49,7 \%$ & $31,1 \%$ & $13,9 \%$ & $2,0 \%$ & $\begin{array}{l}100 \% \\
(151)\end{array}$ \\
VVD & $6,1 \%$ & $22,0 \%$ & $46,3 \%$ & $15,9 \%$ & $9,8 \%$ & $\begin{array}{l}100 \% \\
(81)\end{array}$ \\
Klein Links* & $2,3 \%$ & $52,3 \%$ & $34,1 \%$ & $6,8 \%$ & $4,5 \%$ & $\begin{array}{l}100 \% \\
(15)\end{array}$ \\
Totaal Limburg & $2,6 \%$ & $24,4 \%$ & $34,5 \%$ & $24,4 \%$ & $14,1 \%$ & $\begin{array}{l}100 \% \\
\text { Totaal overig Ned. }\end{array}$ \\
& $2,5 \%$ & $23,4 \%$ & $37,6 \%$ & $25,9 \%$ & $10,6 \%$ & $\begin{array}{l}100 \% \\
(10.415)\end{array}$ \\
\hline
\end{tabular}

* Uitsluitend de in de tabel genoemde partijen; ** Klein links = D66, PPR, PSP, CPN en PAK. Bron: CBS, Statistieken der verkiezingen 
van het percentage twintigers, veertigers en zestigers, stond een daling van het percentage dertigers en vijftigers, zodat noch van vergrijzing, noch van verjonging kan worden gesproken.

In beide verkiezingsjaren was er overigens geen sprake van een sterke afwijking van het leeftijdspatroon van Limburgse raadsleden ten opzichte van het leeftijdspatroon van raadsleden in de rest van het land.

\section{Geografische herkomst}

Een kleine 90 procent van de lijsttrekkers had zijn jeugd in de provincie Limburg doorgebracht. Nog boven dit gemiddelde lagen lijsttrekkers van het CDA (allen Limburger) en van lokale lijsten. Wanneer wij de geografische herkomst nader inperken tot de gemeente waarin men als lijsttrekker functioneerde, dan blijken de verschillen tussen de respondenten van de onderscheiden typen lijsten groter te worden.

In tabel 6.5 is weergegeven hoeveel jaren de respondenten in hun gemeente hadden gewoond, op het moment dat zij in 1982 als lijsttrekker optraden. Daarbij zijn de lijsttrekkers ingedeeld in de categorieèn: lokale lijsten, CDA en overige landelijke lijsten.

Uit tabel 6.5 komt opnieuw een contrast naar voren tussen lijsttrekkers van lokale lijsten en CDA enerzijds en respondenten van overige landelijke lijsten anderzijds. Het overgrote deel van de eersten woonde in 1982 twintig jaar of langer in de gemeente waarin men in dat verkiezingsjaar als lijstaanvoerder fungeerde. Bij de overige landelijke lijsten vormde die categorie respondenten daarentegen een minderheid van ruim een derde van het totaal.

\section{Opleiding}

Aanzienlijke verschillen tussen lokale en landelijke lijsten waren er ook qua opleidingsniveau van de lijsttrekkers. Dit is in tabel 6.6 weergegeven.

Een meerderheid ( 55 procent) van de respondenten van lokale lijsten heeft een lager opleidingsniveau genoten. $\mathrm{Bij}$ de respondenten van landelijke lijsten bedraagt het percentage lager opgeleiden slechts 18 procent. $\mathrm{Bij}$ deze groep is daarentegen sprake van een bijna tweederde meerderheid van hoger opgeleiden. Opvallend is de tweedeling bij CDA-lijsttrekkers met een bijna gelijk aantal lager en hoger opgeleiden. Bij de lijstaanvoerders van de overige landelijke partijen treft men nauwelijks lager opgeleiden aan.

\section{Beroep}

Qua beroepssector vertoonden respondenten van zowel lokale als landelijke lijsten een grote mate van verscheidenheid. De verschillende beroepen zijn gerubriceerd in de categorieën: land- en tuinbouw, industrie en delfstoffenwinning, commerciële dienstverlening, detailhandel, overheid en semi-overheid, bestaande uit instellingen op de terreinen onderwijs, gezondheidszorg en welzijn. Bij respondenten zonder betaald werk is uitgegaan van de laatste werkkring die men had. In tabel 6.7.a. is het resultaat van dit onderdeel van de enquête weergegeven. 
Tabel 6.5. Lijsttrekkers naar aantal jaren dat ze in 1982 in de gemeente waarin men ain verkiezingen meedeed gewoond hadden en naar type lijst.

\begin{tabular}{lllll}
\hline & \multicolumn{2}{l}{ Aantal jaren } & & \\
\cline { 2 - 5 } & $\leq 9$ & $10-19$ & 220 & Totaal \\
\hline Lokale lijsten & 3 & 6 & 46 & 55 \\
CDA & $(5 \%)$ & $(11 \%)$ & $(84 \%)$ & $(100 \%)$ \\
Overige landelijke lijsten & - & 1 & 9 & 10 \\
Totaal & 9 & $(10 \%)$ & $(90 \%)$ & $(100 \%)$ \\
& $(28 \%)$ & $(36 \%)$ & $(36 \%)$ & $(100 \%)$ \\
& 12 & 19 & 67 & 98 \\
& $(12 \%)$ & $(19 \%)$ & $(69 \%)$ & $(100 \%)$ \\
\hline
\end{tabular}

$\mathrm{chi}^{2}=24,44 ;(p \leq 0,005)$

Bron: Lijsttrekkersenquête, RL

Tabel 6.6. Lijsttrekkers naar opleidingsniveau en type lijst.

\begin{tabular}{lllll}
\hline & \multicolumn{2}{l}{ Opleidingsniveau } & \\
\cline { 2 - 3 } & lager & middelbaar & hoger* & Totaal \\
\hline Lokale lijsten & 30 & 16 & 9 & 55 \\
Landelijke lijsten & $(55 \%)$ & $(29 \%)$ & $(16 \%)$ & $(100 \%)$ \\
& 8 & 9 & 26 & 43 \\
chi ${ }^{2}=21,66 ;(p \leq 0,005)$ & $(18 \%)$ & $(21 \%)$ & $(61 \%)$ & $(100 \%)$ \\
CDA & & & & \\
PvdA & & & & \\
VVD & 4 & 1 & 5 & 10 \\
Klein Links & 2 & 1 & 6 & 9 \\
Totaal & 1 & 4 & 7 & 11 \\
& 37 & 25 & 36 & 98 \\
\hline
\end{tabular}

* lager = LO, LBO en MAVO-niveau; middelbaar = HAVO, VWO en MBO-niveau; hoger = HBO en WO-niveau.

Bron: Lijsttrekkersenquête, RL

Een opvallend gegeven uit deze tabel is dat de land- en tuinbouwsector vrijwel niet vertegenwoordigd was bij de lijsttrekkers van landelijke lijsten, terwijl 17 procent van de lijsttrekkers van lokale lijsten in deze sector werkzaam was. In de sectoren industrie- en delfstoffenwinning en overheid waren relatief meer respondenten van 
Tabel 6.7 a Lijsttrekkers naar beroepssector en type lijst.

\begin{tabular}{llll}
\hline & Lokaal & Landelijk & Totaal \\
\hline land- en tuinbouw & 9 & 1 & 10 \\
industrie en delfstoffenwinning & $(17 \%)$ & $(2 \%)$ & $(10 \%)$ \\
commerciële dienstverlening & 15 & 7 & 22 \\
& $(27 \%)$ & $(17 \%)$ & $(23 \%)$ \\
detailhandel & 5 & 6 & 11 \\
overheid & $(9 \%)$ & $(14 \%)$ & $(11 \%)$ \\
semi-overheid & 7 & 4 & 11 \\
overig* & $(13 \%)$ & $(10 \%)$ & $(11 \%)$ \\
& 10 & 5 & 15 \\
Total & $(19 \%)$ & $(12 \%)$ & $(15 \%)$ \\
geen antwoord** & 7 & 15 & 22 \\
& $(13 \%)$ & $(35 \%)$ & $(23 \%)$ \\
\hline
\end{tabular}

$\mathrm{chi}^{2}=15,33 ;(\mathrm{p} \leq 0,025)$

* De volgende beroepen konden niet in eén van de bovenstaande categorieën worden ondergebracht aangezien nadere specificatie ontbrak: secretaresse, administratief medewerker, arbeidsanalist (allen kleinere linkse partijen); personeelschef (PvdA) en administrateur (lokale lijst); ${ }^{* *}$ Het betrof eén huisvrouw en é́n werkloze.

Bron: Lijsttrekkersenquête, RL.

Tabel 6.7.b Lijsttrekkers naar beroepssector en type lijst.

\begin{tabular}{lllll}
\hline & Lokaal & CDANVD & PvdA/K1.Links Totaal \\
\hline private sector & 36 & 13 & 5 & 54 \\
publieke sector & $(65 \%)$ & $(62 \%)$ & $(29 \%)$ & $(59 \%)$ \\
& 17 & 8 & 12 & 37 \\
Totaal & $(35 \%)$ & $(38 \%)$ & $(71 \%)$ & $(41 \%)$ \\
geen antwoord/overigen & 53 & 21 & 17 & 91 \\
\hline
\end{tabular}

$\operatorname{chi}^{2}=7,89 ;(\mathrm{p} \leq 0,025)$

lokale dan van landelijke lijsten werkzaam. Het omgekeerde gold voor de sectoren commerciële dienstverlening en semi-overheid.

Een nadere toespitsing op twee sectoren, namelijk de private sector (omvattende de eerste vier categorieën) en de publieke sector (omvattende de laatste twee catego- 
Tabel 6.8. Politiek actieve familieleden van lijsttrekkers, naar type lijst.

\begin{tabular}{llll}
\hline & \multicolumn{2}{l}{ Politiek actieve familieleden } & \\
\cline { 2 - 3 } & wel & niet & Totaal \\
\hline Lokale lijsten & 20 & 35 & 55 \\
& $(36 \%)$ & $(64 \%)$ & $(100 \%)$ \\
Landelijke lijsten & 14 & 29 & 43 \\
& $(33 \%)$ & $(67 \%)$ & $(100 \%)$ \\
chi2 $=0,15 ;$ (niet significant) & & & \\
CDA & & & \\
PvdA & 4 & 6 & 10 \\
Klein Links & 2 & 7 & 9 \\
VVD & 5 & 8 & 13 \\
& 3 & 8 & 11 \\
Totaal & 34 & & 98 \\
& $(35 \%)$ & $(65 \%)$ & $(100 \%)$ \\
\hline
\end{tabular}

Bron: Lijsttrekkersenquête, RL

rieën), geeft een nog duidelijker contrast te zien. Uit de cijfers blijkt dat de verdeling over deze beide sectoren bij CDA- en VVD-respondenten vrijwel gelijk was en sterk verschilde van de verdeling bij de respondenten van overige landelijke lijsten. In tabel 6.7.b zijn de VVD'ers en CDA'ers dan ook in één categorie ondergebracht.

De verschillen tussen lokale en landelijke lijsttrekkers worden met name veroorzaakt door de respondenten van de PvdA en de kleinere linkse partijen die voomamelijk in de publieke sector werkzaam waren. Zowel van de respondenten van lokale lijsten, als van de lijsttrekkers van respectievelijk het CDA en de VVD werkte daarentegen ongeveer tweederde in de private sector.

Corresponderend met de gegevens betreffende de beroepssector en het opleidingsniveau was er ook een grote mate van variatie in de specifieke beroepen die door de respondenten van de verschillende typen lijsten zijn opgegeven.

Bij de lijsttrekkers van lokale lijsten vonden wij grotere aantallen lager administratief personeel (11), lager technisch personeel (9) en agrariërs (9). Kleinere groepen vormden de (ex)mijnwerkers (5), de horeca-ondememers (4) en beroepen die verbonden zijn met onderwijs en maatschappelijk werk (5).

De CDA'ers vertoonden qua beroep een zeer heterogeen beeld, zonder dominantie van een bepaalde categorie. Bij de PvdA en de kleinere linkse partijen was een grote concentratie van onderwijsgevenden (7) zichtbaar. Beroepen in de 'sociale' sector als arbeidsdeskundige en maatschappelijk werker kwamen onder deze respondenten ook nogal eens voor (5). De VVD'ers bekleedden over het algemeen leidinggevende functies binnen commerciële instellingen of waren werkzaam als zelfstandig ondernemer dan wel in een vrij beroep. 
Tabel 6.9. Lijsttrekkers naar opgegeven aantal verenigingslidmaatschappen en type lijst.

\begin{tabular}{llll}
\hline & \multicolumn{2}{l}{ Aantal lidmaatschappen } & \\
\cline { 2 - 3 } & geen/1 & $2 / 3$ & Totaal \\
\hline Lokale lijsten & 20 & 35 & 55 \\
Landelijke lijsten & $(36 \%)$ & $(64 \%)$ & $(100 \%)$ \\
& 26 & 17 & 43 \\
chi ${ }^{2}=5,60 ;(p \leq 0,025)$ & $(60 \%)$ & $(40 \%)$ & $(100 \%)$ \\
CDA & & & \\
PvdA & & & \\
VVD & 2 & 8 & 10 \\
Klein Links & 7 & 2 & 9 \\
Totaal & 7 & 4 & 11 \\
& 10 & 3 & 13 \\
\hline
\end{tabular}

Bron: Lijsttrekkersenquête, RL

Tabel 6.10. Lijsttrekkers die verenigingslid zijn, naar lidmaatschap van een bestuur en type lijst.

\begin{tabular}{llll}
\hline & \multicolumn{2}{l}{ Bestuursfunctie } & \\
\cline { 2 - 3 } & wel & niet & Totaal \\
\hline Lokale lijsten & 42 & 4 & 46 \\
Landelijke lijsten & $(91 \%)$ & $(8 \%)$ & $(100 \%)$ \\
& 23 & 9 & 32 \\
chi ${ }^{2}=5,23 ;(p \leq 0,025)$ & $(72 \%)$ & $(28 \%)$ & $(100 \%)$ \\
CDA & & & \\
PvdA & & & \\
VVD & 9 & 1 & 10 \\
Klein Links & 3 & 2 & 5 \\
Totaal & 6 & 2 & 8 \\
& 5 & 4 & 9 \\
\hline
\end{tabular}

Bron: Lijsttrekkersenquête, RL 


\section{Familietradidies}

Ongeveer een derde van alle lijsttrekkers in de steekproef noemde één of meer familieleden - men kon er maximaal drie opgeven - die in de gemeentepolitiek actief zijn (of zijn geweest), hetzij in de eigen, hetzij in een andere gemeente. In totaal werden 58 politiek actieve familieleden genoemd. De cijfers die in tabel 6.8 zijn weergegeven maken duidelijk dat er op dit punt geen significant verschil tussen de typen lijsten bestaat.

Slechts bij een minderheid van veertien van de door respondenten genoemde politiek actieve familieleden, ging het om één van de ouders van de respondent. Dit houdt in dat bij 14 van de 98 Limburgse lijsttrekkers in de steekproef sprake was van opvolging van vader op zoon, ook wel aangeduid als 'succession politics' (Grant, 1978).

\section{Verenigingsactiviteiten}

Een groot aantal lijsttrekkers blijkt lid te zijn van niet-politieke en semi-politieke organen en organisaties. Tabel 6.9 geeft hiervan een overzicht. De respondenten konden maximaal drie verenigingen noemen waarvan zij in het verkiezingsjaar 1982 (en eerder) lid waren. In totaal werden er 153 verenigingen genoemd.

Opnieuw blijkt er sprake van een tweedeling van de respondenten. Lijsttrekkers van lokale lijsten waren over het algemeen actiever in het verenigingsleven dan lijsttrekkers van landelijke lijsten. Bijna tweederde van hen gaf twee of meer lidmaatschappen op, bij de landelijke lijstaanvoerders was dat slechts 40 procent.

Een nadere uitsplitsing over verschillende landelijke partijen laat zien dat vooral de $C D A$ 'ers actief waren in het verenigingsleven. Een CDA-respondent die geen lid van een vereniging was, kwam niet voor; bij de overige landelijke partijen bedroeg het aantal niet-leden 11 (van de 33) personen.

\section{Soort verenigingen}

Om welke verenigingen het bij deze lidmaatschappen ging, is nader onderzocht. Daarbij zijn drie categorieën onderscheiden, te weten: sportverenigingen, gezelligheidsverenigingen en belangenverenigingen. Voorbeelden van gezelligheidsverenigingen zijn camavalsverenigingen, schutterijen, harmonieën en andere muziekverenigingen. Onder belangenverenigingen worden onder andere verstaan: vakbonden, boerenbonden en verenigingen van ondememers en winkeliers.

Sportverenigingen werden het meest genoemd door respondenten van beide typen lijsten. Het aantal door de respondenten genoemde verenigingen van dit type bedroeg 61. Naast deze categorie waren ook veel lijsttrekkers lid van gezelligheidsverenigingen. In totaal werden 47 van dit soort verenigingen genoemd. Lidmaatschappen van belangenverenigingen werden iets minder vaak genoemd, namelijk 41 keer. ${ }^{4}$

Respondenten van verschillende typen lijsten hadden van elkaar onderscheiden voorkeuren voor bepaalde soorten verenigingen. In de sector gezelligheidsverenigin-

4 Vier verenigingen konden niet in én van deze drie categorieën worden ondergebracht. 
gen vindt men vrijwel uitsluitend lijsttrekkers van het CDA en lokale lijsten. Dat geldt ook voor de belangenverenigingen. In deze categorie treffen wij echter ook een aantal lijsttrekkers van kleine linkse partijen aan. De PvdA- en VVD-respondenten blijken, voor zover ze al lid zijn van een vereniging, vooral te hebben gekozen voor sportverenigingen.

\section{Bestuursfuncties}

Binnen de verschillende verenigingen bekleedden de lijsttrekkers in veel gevallen een bestuursfunctie. In tabel 6.10 is aangegeven hoeveel van de verenigingsleden onder de respondenten tevens opgaven lid te zijn van tenminste één verenigingsbestuur.

Ook ten aanzien van bestuurlijke activiteiten waren de respondenten van lokale lijsten en het CDA veruit het meest actief. Circa negentig procent van de verenigingsleden die voor deze lijsten als lijstaanvoerder optraden bekleedde tevens tenminste één bestuurslidmaatschap. Bij de verschillende bestuursfunkties (in totaal 115) ging het vaak om het voorzitterschap (53 keer).

\section{Organen}

Naast verenigingen zijn er in een lokale gemeenschap ook nog allerlei, veelal semipublieke, 'organen' die funkties voor vrijwilligers kennen. Hierbij is te denken aan instellingen op het gebied van welzijn, volksgezondheid en cultuur, woningbouwcorporaties, buurtwerk, school- en kerkbesturen. In tabel 6.11 is weergegeven in welke mate de respondenten in dit soort organen actief waren. (De respondenten konden maximaal drie organen noemen.)

In vergelijking met de verenigingslidmaatschappen valt een geringere deelname van alle lijsttrekkers tezamen op. In totaal zijn 81 functies genoemd. Daamaast bestaat er op dit punt, anders dan bij de verenigingen, weinig verschil tussen landelijke en lokale lijsten. Binnen de groep van landelijke lijsttrekkers waren opnieuw de CDA'ers het meest actief.

Om een indruk te geven van de aard van de organen of instellingen waarbinnen de lijsttrekkers participeerden zijn deze in tabel 6.12 in een aantal categorieën gerubriceerd.

De lijsttrekkers blijken het meest actief te zijn geweest in het buurtwerk en in organen op het terrein van welzijn, volksgezondheid en cultuur. De deelname aan besturen van scholen, kerken en woningbouwcorporaties was aanmerkelijk geringer. Er waren tussen de typen lijsten geen in het oog springende verschillen wat de verdeling over sectoren betreft.

In tabel 6.13, tenslotte, is een overzicht gegeven van de optelling van het aantal lidmaatschappen van verenigingen en organen per respondent.

Uit dit overzicht blijkt opnieuw dat vooral de CDA-lijsttrekkers zich bijzonder actief betoonden. De respondenten van de overige landelijke lijsten blijven daarbij achter, zoals blijkt uit het veel lagere gemiddelde aantal lidmaatschappen per lijsttrekker van dit type lijsten. ${ }^{5}$ 
Tabel 6.11. Lijsttrekkers naar aantal functies binnen (niet-politieke) organen, en type lijst.

\begin{tabular}{|c|c|c|c|}
\hline & \multicolumn{2}{|c|}{ Aantal functies } & \multirow[b]{2}{*}{ Totaal } \\
\hline & geen/1 & $2 / 3$ & \\
\hline Lokale lijsten & $\begin{array}{l}43 \\
(78 \%)\end{array}$ & $\begin{array}{l}12 \\
(22 \%)\end{array}$ & $\begin{array}{l}55 \\
(100 \%)\end{array}$ \\
\hline Landelijke lijsten & $\begin{array}{l}34 \\
(79 \%)\end{array}$ & $\begin{array}{c}9 \\
(21 \%)\end{array}$ & $\begin{array}{l}43 \\
(100 \%)\end{array}$ \\
\hline \multicolumn{4}{|c|}{ chi $^{2}=0,01 ;$ (niet-sign.) } \\
\hline CDA & 5 & 5 & 10 \\
\hline PvdA & 8 & 1 & 9 \\
\hline VVD & 10 & 1 & 11 \\
\hline Klein Links & 11 & 2 & 13 \\
\hline Totaal & $\begin{array}{l}77 \\
(79 \%)\end{array}$ & $\begin{array}{l}21 \\
(21 \%)\end{array}$ & $\begin{array}{l}98 \\
(100 \%)\end{array}$ \\
\hline
\end{tabular}

Bron: Lijsttrekkersenquête, RL

Tabel 6.12. Aard van de organen waarbinnen lijstrekkers functies vervullen.

Aard van het orgaan Aantal opgegeven lidmaatschappen

$\begin{array}{lr}\text { buurtwerk } & 26 \\ \text { welzijn/volksgezondheid/cultuur } & 26 \\ \text { huisvesting } & 6 \\ \text { onderwijs } & 5 \\ \text { kerk } & 4 \\ \text { overig } & 14 \\ \text { Totaal } & 81\end{array}$

Bron: Lijsttrekkersenquête, RL

\section{Kerkelijkheid en kerksheid}

Om een indruk te krijgen van de kerkelijkheid van de lijsttrekkers is aan hen de volgende vraag voorgelegd: "Rekent u zich thans te behoren tot een kerkgenootschap, een godsdienstige groepering of een vereniging op levensbeschouwelijke grondslag?"

5 De celfrequenties in deze tabel zijn te klein om met behulp van de chi ${ }^{2}$-toets uitsluitsel te kunnen geven over de significantie van de gevonden verschillen. 
Tabel 6.13. Lijsttrekkeis naar opgegeven aantal lidmaatschappen van verenigingen en organen en type lijst.

\begin{tabular}{|c|c|c|c|c|c|c|c|c|c|}
\hline & \multicolumn{7}{|c|}{ Aantal lidmaatschappen } & \multirow[b]{2}{*}{ Totaal } & \multirow[b]{2}{*}{ Gemid } \\
\hline & 0 & 1 & 2 & 3 & 4 & 5 & 6 & & \\
\hline Lokale lijsten & 7 & 4 & 9 & 22 & 9 & 3 & 1 & 55 & 2,6 \\
\hline Landelijke lijsten & 6 & 11 & 11 & 9 & 2 & 3 & 1 & 43 & 2,1 \\
\hline $\mathrm{CDA}$ & - & - & 1 & 4 & 1 & 3 & 1 & 10 & 3.5 \\
\hline PvdA & 1 & 3 & 2 & 2 & - & - & - & 8 & 1,6 \\
\hline VVD & 2 & 4 & 2 & 2 & 1 & - & - & 11 & 1,6 \\
\hline Klein Links & 3 & 4 & 6 & 1 & - & - & - & 14 & 1,6 \\
\hline Totaal & 13 & 15 & 20 & 31 & 12 & 6 & 2 & 98 & 2,4 \\
\hline
\end{tabular}

Bron: Lijsttrekkersenquête, RL

Tabel 6.14. Lijstrrekkers naar kerkelijkheid en type lijst.

\begin{tabular}{|c|c|c|c|c|}
\hline & \multicolumn{2}{|c|}{ Kerkelijk } & \multirow[b]{2}{*}{ Totaal } & \multirow{2}{*}{$\begin{array}{l}\text { geen } \\
\text { antwoord }\end{array}$} \\
\hline & wel & niet & & \\
\hline Lokale lijsten & $\begin{array}{l}50 \\
(91 \%)\end{array}$ & $\begin{array}{l}5 \\
(9 \%)\end{array}$ & $\begin{array}{l}55 \\
(100 \%)\end{array}$ & - \\
\hline Landelijke lijsten & $\begin{array}{l}25 \\
(60 \%)\end{array}$ & $\begin{array}{l}17 \\
(40 \%)\end{array}$ & $\begin{array}{l}42 \\
(100 \%)\end{array}$ & 1 \\
\hline \multicolumn{5}{|c|}{$\operatorname{chi}^{2}=14,03 ;(p \leq 0,005)$} \\
\hline CDA & 10 & - & 10 & - \\
\hline PrdA & 2 & 7 & 9 & - \\
\hline VVD & 8 & 3 & 11 & - \\
\hline Klein Links & 5 & 7 & 12 & 1 \\
\hline Totaal & $\begin{array}{l}75 \\
(77 \%)\end{array}$ & $\begin{array}{l}22 \\
(23 \%)\end{array}$ & $\begin{array}{l}97 \\
(100 \%)\end{array}$ & 1 \\
\hline
\end{tabular}

Bron: Lijsttrekkersenquête, RL

Tabel 6.14 laat zien dat het contrast tussen de respondenten van verschillende typen lijsten opnieuw bijzonder groot is.

Uit deze tabel is af te leiden dat de respondenten van lokale lijsten in meerdere mate kerkelijk waren dan hun collega's van landelijke lijsten. Bij uitsplitsing van de laatste categorie naar verschillende politieke partijen, blijkt dat het verschil voortkomt uit het relatief geringere aantal kerkelijke respondenten van de PvdA en de kleinere linkse 
Tabel 6.15. Kerkelijke lijsttrekkers naar mate van kerksheid en type lijst.

\begin{tabular}{|c|c|c|c|c|c|}
\hline & \multicolumn{4}{|c|}{ Kerkbezoek } & \multirow[b]{2}{*}{ Totaal } \\
\hline & wekelijks & maande & s jaarlijks & zelden & \\
\hline Lokale lijsten & $\begin{array}{l}23 \\
(46 \%)\end{array}$ & $\begin{array}{l}12 \\
(24 \%)\end{array}$ & $\begin{array}{l}10 \\
(20 \%)\end{array}$ & $\begin{array}{l}5 \\
(10 \%)\end{array}$ & $\begin{array}{l}50 \\
(100 \%)\end{array}$ \\
\hline Landelijke lijsten & $\begin{array}{l}9 \\
(36 \%)\end{array}$ & $\begin{array}{l}5 \\
(20 \%)\end{array}$ & $\begin{array}{l}9 \\
(36 \%)\end{array}$ & $\begin{array}{l}2 \\
(8 \%)\end{array}$ & $\begin{array}{l}25 \\
(100 \%)\end{array}$ \\
\hline \multicolumn{6}{|c|}{ chi $^{2}=2,26 ;$ (niet-sign.) } \\
\hline CDA & 8 & 2 & - & - & 10 \\
\hline PvdA & - & 1 & 1 & - & 2 \\
\hline VVD & 1 & - & 6 & 1 & 8 \\
\hline Klein Links & - & 2 & 2 & 1 & 5 \\
\hline Totaal & $\begin{array}{l}32 \\
(43 \%)\end{array}$ & $\begin{array}{l}17 \\
(23 \%)\end{array}$ & $\begin{array}{l}19 \\
(25 \%)\end{array}$ & $\begin{array}{l}7 \\
(9 \%)\end{array}$ & $\begin{array}{l}75 \\
(100 \%)\end{array}$ \\
\hline
\end{tabular}

Bron: Lijsttrekkersenquête, RL

partijen. Bij de VVD'ers waren de kerkelijken in de meerderheid. De kerkelijke respondenten van alle lijsten behoorden vrijwel zonder uitzondering tot de Rooms-Katholieke kerk.

Aan de groep kerkelijken is vervolgens gevraagd hoe vaak men in het algemeen naar de kerk of een religieuze bijeenkomst gaat. De volgende antwoordcategorieën werden daarna (op een kaart) voorgelegd (tussen haakjes staat de aanduiding in de tabel): 'vrijwel elke week of vaker' (wekelijks); '1 à 2 keer per maand' (maandelijks); 'enkele keren per jaar' (jaarlijks); 'zelden'; 'nooit', (deze laatste categorie is niet opgenomen in tabel 6.15 aangezien geen van de respondenten dit antwoord had gekozen). Een antwoordpatroon dat vergelijkbaar is met het hierboven beschrevene, is het resultaat.

De CDA-lijsttrekkers waren niet alleen het meest kerkelijk maar ook het meest kerks. Het kerkbezoek van de lijsttrekkers van lokale lijsten was relatief hoog. Bij de overige respondenten was de mate van kerksheid aanmerkelijk lager. Het verschil tussen lijsttrekkers van alle landelijke lijsten bij elkaar opgeteld en lijsttrekkers van lokale lijsten is niet significant.

\section{Samenvatting: het profiel van de lijsttrekkers}

Samenvattend kunnen wij stellen dat de doorsnee aan de enquête deelnemende lijsttrekker van een lokale lijst ruim vijftig jaar oud is, zijn hele leven heeft geleefd in de gemeente waar hij als lijsttrekker functioneert, sterk betrokken is bij de Rooms-Katholieke kerk en lid is van een aantal plaatselijke verenigingen. Hij is werkzaam in de private sector en heeft een relatief laag opleidingsniveau. 
De gemiddelde CDA-lijsttrekker sluit goed aan bij dit profiel, zij het dat er sprake is van een hoger opleidingsniveau. Ten opzichte van alle andere respondenten vallen de CDA'ers daarnaast op door hun grote mate van betrokkenheid bij het verenigingsleven en de kerk, alsmede door relatief veel activiteiten in semi-publieke organen en instellingen.

De lijsttrekkers van de overige landelijke partijen onderscheiden zich van de voorgaande categorieën door een beduidend hoger opleidingsniveau, een lagere mate van kerkelijkheid en kerksheid, minder buiten-politieke bestuurlijke activiteiten en een lagere leeftijd. De meeste lijsttrekkers van PvdA en kleinere linkse partijen zijn bovendien - in afwijking van de andere respondenten - werkzaam in de publieke sector.

Ten aanzien van het geslacht van de politicus en de aanwezigheid van familiaire banden met andere lokale politici zijn er geen grote afwijkingen te constateren tussen de verschillende typen lijsten. Wanneer de analyse verbreed wordt naar de Limburgse raadsleden dan blijkt het percentage vrouwen bij de lokale lijsten en het CDA echter beduidend lager dan bij de overige landelijke lijsten.

\section{b. Recruteringservaringen van lijsttrekkers}

Een meer directe aanwijzing voor het belang van diverse factoren tijdens het proces van recrutering van lokale politici, vormt de beantwoording op een daarop betrekking hebbende vraag uit de schriftelijke enquête die luidde: "Toen u zich, hetzij uit eigener beweging, hetzij door anderen gevraagd, voor het eerst kandidaat stelde bij raadsverkiezingen, hoe belangrijk waren toen voor u de volgende factoren?" Onder deze vraag waren de volgende factoren opgesomd, waarbij men de drie antwoordcategorieën 'heel belangrijk', 'enigszins belangrijk' en 'niet of nawwelijks belangrijk' kon aankruisen:

- bekendheid met eén of meer zittende raadsleden;

- activiteiten in het verenigingsleven en/of kerkgenootschappen;

- activiteiten in bepaalde organen als schoolbesturen, woningbouwverenigingen, buurtcentra etc.;

- beroep;

- het feit dat men in een hepaald dorp of stadsdeel woont;

- het feit dat éen of meer familieleden actief zijn (geweest) in de lokale politiek;

- activiteiten binnen de organisatie van de eigen politieke groepering.

In Appendix III is een overzicht gegeven van de antwoorden bij de verschillende factoren.

Significante verschillen tussen de drie categorieën lijsttrekkers zijn gevonden voor de volgende vier factoren: bekendheid met zittende raadsleden, activiteiten in het verenigingsleven en/of kerkgenootschappen, politiek actieve familieleden en activiteiten binnen de eigen politieke groepering. Voor de eerste drie factoren geldt dat lijsttrekkers van lokiale lijsten deze over het algemeen belangrijker achtten dan lijsttrekkers van landelijke lijsten, bij de laatste factor is het omgekeerde het geval (met uitzondering van de CDA-lijsttrekkers). 
Tabel 6.16. Mening van lijstrekkers over de rol van een aantal factoren bij de eerste kandidaatstelling. naar type lijst (gemiddelden).

\begin{tabular}{lllll}
\hline & Lokaal & CDA & Ov. landelijk & Totaal \\
\hline bekendheid raadsleden & 2,0 & 1,2 & 1,2 & 1,4 \\
verenigingsactiviteiten & 2,5 & 2,2 & 1,5 & 1,9 \\
activiteiten in organen & 1,8 & 1,2 & 1,7 & 1,7 \\
beroep & 1,7 & 1,4 & 1,3 & 1,5 \\
dorp/buurt & 2,0 & 1,7 & 1,3 & 1,7 \\
familie in politiek & 1,5 & 1,1 & 1,0 & 1,3 \\
activiteiten in groepering & 2,0 & 1,7 & 3,2 & 2,3 \\
aantal respondenten & $(31)$ & $(9)$ & $(18)$ & $(58)$ \\
\hline
\end{tabular}

Bron: Lijsttrekkersenquête, RL

Aan de hand van de in de Appendix weergegeven data is een samenvattend overzicht samengesteld op basis van de gemiddelde waarden die respondenten van elk van de drie categorieën lijsten toekenden aan de verschillende factoren. Daartoe is aan het antwoord 'heel belangrijk' drie punten toegerekend, aan 'enigszins belangrijk' twee punten en aan 'niet belangrijk' tenslotte één punt. De op deze wijze verkregen puntentotalen zijn vervolgens gedeeld door het aantal respondenten in de betreffende categorie, waardoor een gemiddelde waarde wordt verkregen. Deze gemiddelden zijn te vinden in tabel 6.16. (De in deze tabel verkort opgenomen factoren corresponderen met de hierboven volledig aangeduide factoren.)

De twee factoren waaraan door de respondenten gemiddeld het hoogste gewicht wordt toegekend zijn verenigingsactiviteiten en activiteiten binnen de eigen politieke groepering. Daarbij legden de respondenten van de lokale lijsten en het CDA heel duidelijk de nadruk op het eerste, die van de overige landelijke lijsten juist op het tweede type activiteit. Voor de lijsttrekkers van landelijke partijen anders dan het CDA vormden de activiteiten binnen de eigen politieke groepering zelfs de enige factor die door een (grote) meerderheid van hen als heel belangrijk werd ervaren.

Het dorp of stadsdeel waarin men woont blijkt vooral bij lijsttrekkers van verschillende lokale lijsten een belangrijke rol te hebben gespeeld. Dat geldt ook voor de bekendheid met een of meer zittende raadsleden en activiteiten in semi-publieke organen, factoren die door landelijke lijsttrekkers duidelijk minder belangrijk werden gevonden.

Een meerderheid van de CDA-respondenten achtte bijna geen enkele van de genoemde factoren belangrijk bij hun eerste kandidaatstelling. De enige uitzondering betreft de activiteiten in het verenigingsleven.

Het al of niet hebben van familieleden in de lokale politiek scoorde relatief laag bij alle categorieën respondenten. Dat gold ook, zij het in mindere mate, voor de factor beroep. De beroepen van respondenten die deze factor als enigszins of heel belangrijk bestempelden waren overigens zeer uiteenlopend. 
Tabel 6.17. Factor die volgens de lijsttrekkers het zwaarst woog bij hun eerste kandidaatstelling, naar type lijst.

\begin{tabular}{|c|c|c|c|c|}
\hline & Lokaal & $\mathrm{CDA}$ & Ov. landelijk & Totaal \\
\hline bekendheid raadsleden & 1 & - & - & $\begin{array}{l}1 \\
(2 \%)\end{array}$ \\
\hline verenigingsactiviteiten & 11 & 6 & - & $\begin{array}{l}17 \\
(31 \%)\end{array}$ \\
\hline activiteiten in organen & 2 & 1 & 1 & $\begin{array}{l}4 \\
(7 \%)\end{array}$ \\
\hline beroep & 2 & 1 & - & $\begin{array}{l}3 \\
(6 \%)\end{array}$ \\
\hline dorp/buurt & 7 & - & $一$ & $\begin{array}{l}7 \\
(13 \%)\end{array}$ \\
\hline familie in politiek & 2 & - & - & $\begin{array}{l}2 \\
(4 \%)\end{array}$ \\
\hline activiteiten in groepering & - & - & 14 & $\begin{array}{l}14 \\
(26 \%)\end{array}$ \\
\hline overige & 3 & - & 3 & $\begin{array}{l}6 \\
(11 \%)\end{array}$ \\
\hline Totaal & 28 & 8 & 18 & $\begin{array}{l}54 \\
(100 \%)\end{array}$ \\
\hline geen antwoord & 3 & 1 & - & 4 \\
\hline
\end{tabular}

Bron: Lijsttrekkersenquête, RL

Aan de lijsttrekkers is vervolgens gevraagd om aan te geven welke van de hierboven genoemde zeven factoren naar hun oordeel het zwaarst gewogen heeft. Het resultaat is in tabel 6.17 weergegeven.

Ook uit tabel 6.17 komt een tweedeling van lijsttrekkers naar voren ${ }^{6}$. Door CDA'ers en respondenten van lokale lijsten werd de factor verenigingsactiviteiten het meest genoemd als belangrijkste factor bij hun recrutering. Dezelfde factor werd in het geheel niet genoemd door respondenten van de overige landelijke lijsten. Deze laatsten wezen daarentegen bijna unaniem de activiteiten in de eigen politieke groepering als zwaarst wegende factor aan, terwijl die factor juist door geen van de respondenten van CDA en lokale lijsten werd verkozen.

Voor enkele respondenten vormden de activiteiten in verenigingen zelfs het hoofdmotief voor deelname aan gemeenteraadsverkiezingen. De onderstaande citaten uit de beantwoording van de vraag in de mondelinge enquête naar de reden voor deelname aan verkiezingen geven bovendien een aanwijzing voor de manier waarop verenigingsactivisme samenhangt met recrutering voor politieke ambten.

6 De celfrequenties in deze tabel zijn te klein om met behulp van de chi ${ }^{2}$-toets uitsluitsel te kunnen geven uver de significantie van de gevonden verschillen. 
"Ik was in diverse verenigingen bestuurslid en ben er toen gewoon ingerold. Mensen hebben mij gevraagd en toen ben ik meegesleept door hun spontaniteit en inzet".

"Voor 1966 heb ik nooit wat aan politiek gedaan. Ik had er voor die tijd ook helemaal geen interesse in. $\mathrm{k}$ ben toen door verenigingen gevraagd en ik vond dat mijn gemeenschap goed voor de dag moest komen".

"Vanuit het verenigingsleven een vaak 'de neus stoten' bij de gemeente, in verband met subsidies, vergunningen en dergelijke".

"Uit hoofde van functies bij het verenigingsleven, stemmen proberen te vergaren. Verder geen motieven van politieke aard".

\subsection{Achtergronden van recrutering van politieke leiders in Limburg}

De in de vorige paragraaf weergegeven bevindingen laten een aantal duidelijke verschillen zien tussen zowel de kenmerken als de aard van het recruteringsproces van respondenten van het CDA en de lokale lijsten aan de ene kant en respondenten van de overige landelijke lijsten aan de andere kant. In deze paragraaf willen wij enkele mogelijke verklaringen voor deze verschillen formuleren. Daarbij gaan wij achtereenvolgens in op de positie van vrouwen, jongeren, niet-Limburgers en buiten- en rand-kerkelijken, alsmede de rol van opleiding en beroep, familietradities en gemeenschapsactiviteiten. Vooropgesteld zij dat wij op basis van het voorhanden zijnde materiaal niet in staat zijn om eenduidige conclusies te trekken.

\section{Positie van vrouwen}

Uit de percentages vrouwelijke raadsleden en wethouders blijkt dat de lokale politiek in Limburg, meer nog dan in andere delen van het land, vooral een mannenzaak is (vgl. Leijenaar en Niemöller, 1985:106). Voor een deel is dit terug te voeren op ook elders spelende factoren bij de zelfselectie van vrouwen. In dit kader kan met name gewezen worden op de hardnekkigheid van traditionele rollenpatronen, waardoor veel vrouwen een primaire verantwoordelijkheid voor het gezin voelen, die zij onverenigbaar achten met het uitoefenen van politieke functies (vgl. Ministerie van Binnenlandse Zaken, 1983).

Het feit dat er in de noordelijke en westelijke provincies van het land relatief meer vrouwelijke raadsleden zijn dan in Limburg (en in mindere mate Noord-Brabant), duidt daarnaast op een verband met de primair katholieke cultuur in het zuiden. In de Rooms-Katholieke kerk nemen vrouwen, onder andere door hun uitsluiting van het priesterambt, van oudsher een ondergeschikte plaats in. Het ligt voor de hand dat in een samenleving waarin een patriarchale cultuur traditioneel dominant is, zelf-selectie veel vrouwen ervan weerhoudt om politieke ambities te koesteren (vgl. Knippenberg en Korsten, 1991:216).

De traditionele katholieke cultuur veroorzaakt (en wordt op zijn beurt bestendigd door), een mannelijke dominantie binnen de kerk, verenigingen, belangenorganisaties èn politieke partijen, kortom de sociale en politieke elite van de gemeenschap. ${ }^{7}$ De 
hindernis die dit voor vrouwen met zich meebrengt is door Chapman als volgt onder woorden gebracht:

"... women as an out-group by definition lack the attributes of status in all fields of social relations and in particular the profiles of characteristics which the institutions of men are designed to convert into political status, influence and power." (Chapman, 1987:7)

Selectie van vrouwen voor leiderschapsposities van die politieke groeperingen die sterk verbonden zijn met deze patriarchale sociale structuur, is dan ook minder voor de hand liggend. ${ }^{8}$ In dat licht bezien is ook het relatief lage percentage vrouwelijke raadsleden bij lokale lijsten en het CDA, in vergelijking met de andere landelijke partijen verklaarbaar. ${ }^{9}$

Daarnaast kan nog gewezen worden op de van oudsher cliëntelistisch getinte politieke cultuur, waarin belangenbehartiging een zeer prominente plaats inneemt. In de ogen van selectie-functionarissen en van het electoraat zullen vrouwen veelal in mindere mate worden geacht over de hulpbronnen voor effectieve belangenbehartiging te beschikken dan mannen. Bij dit soort hulpbronnen kan men denken aan toegang tot het, eveneens door mannen gedomineerde gemeentelijk apparaat en andere maatschappelijke instituties, kennis, sociale status en financiële middelen.

Opnieuw kan gesteld worden dat de lokale lijsten het sterkst met deze politieke cultuur verbonden zijn. Voor vrouwen geldt dan ook dat zij bij recrutering buiten partij-kaders een geringere kans op selectie door anderen hebben. Maar ook indien sprake is van recrutering via politieke organisaties speelt het probleem van dominantie van mannen in de rol van selectie-functionarissen. De daardoor ontstane natuurlijke tendens om vrouwen bij selectie voor belangrijke posities te passeren, wordt echter vooral binnen landelijke lijsten enigszins tegengegaan door bewuste activiteiten om de positie van vrouwen in de lokale politiek te verbeteren. Dergelijke vormen van 'positieve actie' worden al geruime tijd binnen vrijwel alle politieke partijen uitgevoerd. De hogere percentages vrouwelijke raadsleden en wethouders bij landelijke lijsten in Limburg in vergelijking met lokale lijsten, kunnen mede teruggevoerd worden op deze bewuste poging om de ondervertegenwoordiging van vrouwen te verminderen.

7 De relatie tussen cultuur en sociale structuur op dit punt vormt een voorbeeld van wat door Elias een 'dubbelbindingfiguratie' wordt genoemd (Elias, 1982:53). Een mechanisch oorzaaken-gevolg-model is in dit geval niet toepasbaar.

8 Een opvallende poging om de door mannen gedomineerde recruteringsinstanties te omzeilen, vormde de oprichting van de lijst Vrouwenappłl in de gemeente Landgraaf, in 1986. Deze lijst behaalde in dat jaar in één keer drie zetels.

9 Het is overigens merkwaardig dat Leijenaar en Niemöller het, zelfs ten opzichte van het CDA, bijzonder lage percentage vrouwelijke raadsleden bij lokale lijsten buiten beschouwing laten (Leijenaar en Niemöller, 1985:101). 


\section{Positie van jongeren}

Het feit dat relatief meer jongeren in de rollen van lijsttrekker en van raadsilid deelnemen binnen de landelijke partij-afdelingen, geeft aan dat ook. deze categorie burgers die binnen de traditionele recruteringskaders minder kans heeft, bij landelijke lijsten eerder de politieke ambities gehonoreerd ziet.

Voor een deel kan dit teruggevoerd worden op een incidentele verklarende factor, namelijk het feit dat veel landelijke lijsten in het jaai waar de enquête betrekking op had, pas waren opgericht. Dit bracht een tamelijk jong kader met zich mee. In deze situatie ontbraken personen die op grond van senioriteit en politieke ervaring aanspraak maken op de leiderschapsposities. In veel lokale lijsten en in CDA-afdelingen die tot stand kwamen vanuit (fusies van) lokale lijsten, waren dergelijke personen juist in ruime mate voorhanden. Het verschil in leeftijd van raadsleden van CDA en lokale lijsten ten opzichte van de overige landelijke partijen was echter in 1986 ongeveer even groot als in 1982, zodat ook meer structurele factoren geacht kunnen worden een rol te spelen.

In dit verband kan daamaast opnieuw worden gewezen op de aard van de binding tussen kiezers en gekozenen. Jongeren worden daardoor op gelijksoortige wijze benadeeld als vrouwen. Ook van jongeren kan over het algemeen gesteld worden dat zij niet beschikken over voldoende hulpbronnen voor een, in de ogen van de kiezers, effectieve belangenbehartiging.

\section{Positie van niet-Limburgers}

Een extra handicap voor niet-Limburgers die op zowel de zelf-selectie als de selectie door anderen van invloed is, vormt de Limburgse cultuur met haar hoge mate van eigen identiteit en lokalistische oriëntatie, zich onder meer uitende in een van het Nederlandse sterk afwijkende streektaal. (Zie hierover hoofdstuk 2.)

De weinige niet-Limburgers die lijsttrekker bij de raadsverkiezingen van 1982 waren, maakten vrijwel zonder uitzondering deel uit van landelijke partijen, anders dan het CDA. Binnen deze partijen als recruteringskaders hebben kennelijk niet-Limburgers een grotere kans om een vooraanstaande positie in te nemen.

\section{Positie van buiten-en rand-kerkelijken}

Het is aannemelijk dat de kerk als één van de belangrijkste 'verenigingen' in de lokale gemeenschap, van oudsher een rol speelt bij de recrutering. De ook op het platteland opgetreden secularisering en vermindering van kerksheid heeft er echter toe geleid dat deze factor geleidelijk minder zwaar is gaan wegen.

Dat van die ontwikkeling het minst terug te vinden was bij het CDA is, gelet op het karakter van deze partij, niet verwonderlijk. Buiten deze partij gold voor alle groeperingen, dat de selectie van buiten- en rand-kerkelijken voor het lijsttrekkerschap geen uitzondering meer vormde en in sommige partijen (PvdA en kleinere linkse partijen) zelfs regel was geworden. Bij de overige landelijke lijsten (met uitzondering van het CDA) lijkt het al of niet behoren tot een kerkgenootschap niet relevant te zijn in het recruteringsproces. 


\section{Rol van opleiding en beroep}

Uit onderzoek naar de kenmerken van leden van politieke partijen blijkt dat het vooral personen uit de (economische) middenklasse betreft met een daarbij behorend bovengemiddeld opleidings- en inkomensniveau, een verschijnsel dat wel met de term 'social bias' wordt aangeduid (Andeweg, 1985:101; Hillebrand, 1992:254 e.v.). Selectie binnen het kader van politieke partijen lijkt ten nadele te werken van personen die qua beroep, opleiding en inkomen een relatief lage status bezitten. Op grond hiervan is het aannemelijk dat het in de steekproef gevonden relatief hoge opleidingsniveau van lijsttrekkers van landelijke lijsten samenhangt met het eveneens doorgaans hoge opleidingsniveau van plaatselijke partijkaders.

In hoeverre is er ook sprake van een 'social bias' wanneer de selectie niet in handen is van een in partij-verband georganiseerd kader? De resultaten van het onderzoek van Prewitt in een 'non-partisan'-kader wijzen in de richting van een benadeling van zowel personen die een lagere, als die een duidelijk hogere sociaal-economische positie innemen:

"Natural selection processes, isolate from recruitment networks those citizens furthest removed from the modal socio-economic character of the active stratum" (Prewitt, 1970:41).

De 'social bias' van recrutering werkte in de San Fransisco Bay Area dus naar twee kanten toe. Dit hangt samen met zowel de aanwezige zelf-selectie als de rol die recruteringsinstanties spelen.

In het partijloze recruteringskader in de Limburgse lokale politiek is deze werking van de recrutering goed voorstelbaar. De basis voor een succesvolle politieke carrière wordt immers gevormd door een sterke band met grote groepen kiezers. Personen die, in de woorden van Bax, een 'real local' en een 'good mixer' zijn, hebben daarop de meeste kans. Onder dat laatste verstaat Bax:

".. that one has good contacts with all sorts of people and behaves in the same way as the majority." (Bax, 1976:57)

Deze voorwaarde heeft niet alleen gevolgen ten aanzien van de sociale klasse van de politici. Ook een boven-gemiddeld opleidingsniveau kan in een dergelijke situatie een handicap vormen, terwijl de marginale positie van de eerder genoemde categorieën vrouwen, jongeren, niet-Limburgers en buiten- en rand-kerkelijken eveneens met dit gegeven in verband kan worden gebracht.

De gemiddeld genomen lagere scholingsgraad van de respondenten van de lokale lijsten kan daamaast nog gerelateerd worden aan hun leeftijd, en de leeftijd van de betreffende selektie-functionarissen. Gedurende de oorlog en de daarop volgende wederopbouwperiode waren er voor velen minder mogelijkheden om langdurige opleidingen af te ronden. Binnen deze generatie vormt een laag opleidingsniveau dan ook een minder grote handicap in het recruteringsproces.

In zijn algemeenheid is het aannemelijk dat het ontbreken van formele partijkaders voor recrutering leidt tot afstandsreductie tussen de politieke leiders en de brede massa van de plaatselijke bevolking. Recrutering binnen partijkaders heeft daarentegen in de regel tot gevolg dat die afstand toeneemt. 


\section{Rol van familietradities}

Prewitt heeft in zijn eerder aangehaalde studie gewezen op het belang van vroegtijdige politieke socialisatie, met name in het proces van zelfselectie. Uit het feit dat ook in onze steekproef een groot aantal respondenten aangaf politiek-actieve familieleden te hebben, kunnen we afleiden dat deze factor ook in de Limburgse lokale politiek een rol speelt.

Toch gaf het overgrote deel van de respondenten aan dat deze familiaire betrekkingen geen belangrijke rol hadden gespeeld bij hun eerste kandidaatstelling. Voor slechts twee van hen vormde de familierelatie de belangrijkste factor in hun recruteringsproces. Beide respondenten waren overigens lijstaanvoerder van een lokale lijst. Gevallen van 'opvolgingspolitiek' lijken, althans in de periode waarop het onderzoek betrekking heeft, zoals in de vorige paragraaf al vermeld, tamelijk zeldzaam.

\section{Rol van gemeenschapsactiviteiten}

Uit de lijsttrekkersenquêtes is duidelijk naar voren gekomen dat bij afwezigheid van politieke partijen als recruteringskader, de plaatselijke verenigingen een prominente rol spelen in het recruteringsproces in de Limburgse lokale politiek.

Een sterke positie in het gemeenschapsleven vergroot in een sterk op de persoon gerichte politieke cultuur de eigen electorale mogelijkheden. Voor politici zijn verenigingen interessant als reservoir van stemmen. Deelname aan verenigingen, en vooral ook het uitoefenen van bestuursfuncties daarbinnen, verschaft bovendien een zekere mate van zelfvertrouwen, status en bestuurlijke kennis en ervaring, die de stap naar een politieke functie minder groot maken. Voor verenigingen is een goede band met de politiek van belang onder andere met het oog op subsidieverlening. Wat dit betreft is er kennelijk sprake van een wisselwerking, zoals het in de inleiding aangehaalde citaat van Prewitt reeds suggereerde.

\section{Gevolgen van nationalisering}

Met de introduktie van landelijke partij-afdelingen is een nieuw recruteringskader voor lokale politici geschapen waardoor een aantal groepen die tot nu toe niet of nauwelijks in staat waren om belangrijke posities in de lokale politiek te verwerven daartoe nu beter in staat worden gesteld. Het betreft met name vrouwen, jongeren, niet-Limburgers, rand- en buiten-kerkelijken.

Of de ook in lokale politieke groeperingen en plaatselijke CDA-afdelingen onvermijdelijke wisseling van generaties een afname met zich mee zal brengen van het aantal lager opgeleide, in de primaire en secundaire sector werkzaam zijnde lijsttrekkers, is nog onzeker. In ieder geval staat het vast dat door de deelname van landelijke lijsten een nieuw type hoger opgeleide politici in de Limburgse lokale politiek is geïntroduceerd.

Daarnaast is het te verwachten dat bij het proces van selectie door anderen de activiteiten binnen politieke organisaties (partij-afdelingen dan wel geprofessionaliseerde plaatselijke groeperingen) minstens even zwaar, zo niet zwaarder gaan wegen dan activiteiten in niet-politieke organisaties. De prominente rol van het verenigingsleven als recruteringskanaal voor de lokale politiek zou daarmee verzwakken. 



\section{Hoofdstuk 7}

\section{Collegevorming in Limburgse gemeenten}

\subsection{Inleiding}

In de voorgaande drie hoofdstukken zijn een aantal verschillen tussen lokale en landelijke lijsten geconstateerd ten aanzien van de organisatie en het functioneren van de diverse politieke groeperingen, de binding tussen kiezers en gekozenen, de kenmerken van politieke leiders en de aard van de recruteringsprocessen. Daarbij is ook steeds gewezen op de implicaties van het nationaliseringsproces dat zich in de jaren tachtig in de Limburgse lokale politiek heeft voltrokken.

In dit hoofdstuk staat de collegevorming in Limburgse gemeenten centraal. Dit onderwerp heeft betrekking op de wijze waarop het lokaal bestuur functioneert en op de dynamiek van de onderlinge betrekkingen tussen politieke groeperingen en individuele politici.

Het in Nederland gangbare patroon van collegevorming is enkele jaren geleden door Tops in kaart gebracht. Naar aanleiding van een uitvoerige analyse van de in Nederlandse gemeenten in de periode 1946-1986 gevormde coalities concludeerde Tops:

“.. dat de vorming van afspiegelingscolleges een dorninant en bestendig kenmerk is van de coalitievorming in Nederlandse gemeenten." (Tops, 1990:211)

In een afspiegelingscollege zijn de wethouderszetels over de grootste fracties van de gemeenteraad verdeeld, naar rato van hun zeteltal. Dat resulteert in de regel in een grote mate van consensus over de zetelverdeling en een brede mate van steun van colleges in de raden waar ze uit voort komen.

De situatie in Limburgse gemeenten lijkt echter af te wijken van dit beeld. Tops wijst erop dat in de door hem als 'communaal' bestempelde gemeenteraden, dat wel zeggen raden waarin lokale lijsten de meerderheid van de zetels bezetten, aanmerkelijk minder afspiegelingscolleges werden gevormd. Bovendien verkregen de wethouders in die situatie relatief weinig stemmen op het moment van hun verkiezing. Dit duidt op een mindere mate van consensus dan elders gebruikelijk is. Hij concludeert dan ook dat de coalitievorming in 'communale' gemeenten (waartoe bijna alle Limburgse 
gemeenten tot 1978 behoorden) op een andere wijze moet worden geïnterpreteerd, dan de coalitievorming in 'nationale' gemeenten (Tops, 1990:137).

Gegevens die specifiek op collegevorming in de communalistische periode in Limburg betrekking hebben zijn helaas nogal beperkt. Niettemin kunnen wij aan enkele case-studies aanwijzingen ontlenen over de veelal geringe mate van consensus in deze periode, hetgeen een bevestiging oplevert van de conclusie van Tops ten aanzien van 'communale' gemeenten. Het betreft een analyse van de stemverhoudingen bij wethoudersverkiezingen in een steekproef van 22 kleine Limburgse gemeenten ${ }^{1}$, alsmede de eerder aangehaalde onderzoeken naar de lokale politiek in de gemeenten Sint-Geertruid (Custers, 1988) en Echt (Ohlenforst, 1992) ${ }^{2}$, aangevuld door de conclusies van een onderzoek naar het gedwongen ontslag van wethouders in Limburg (Knippenberg, 1988).

In de tweede paragraaf richten wij ons op de situatie in de periode vanaf de collegevorming in 1982. De centrale vraag daarbij is of de introduktie van landelijke partijen in de gemeentepolitiek gevolgen heeft gehad voor de wijze waarop coalities gevormd werden en colleges functioneerden. Is als gevolg van deze introduktie het elders gangbare patroon van collegevorming op basis van afspiegeling ook in Limburgse gemeenten overgenomen? Is er in verband daarmee ook sprake van een grotere mate van consensus en meer steun voor colleges in de gemeenteraden, alsmede een positieve attitude bij politieke leiders ten aanzien van de wenselijkheid van colleges op brede basis?

Aangezien de landelijke partijen over het algemeen een sterke voorkeur hebben voor de vorming van colleges op brede basis ofwel afspiegelingscolleges (Tops, 1990:86), zou men verwachten dat de nationalisering in de regel tot een grotere mate van steun in de gemeenteraden voor colleges zou leiden. Van het nationaliseringsproces zou op basis van dat gegeven een matigend effect moeten uitgaan. Daar staat echter tegenover dat de mogelijke tegenstelling tussen lokale en landelijke lijsten aanleiding kan vormen voor enige polarisatie tussen beide typen lijsten.

Om de feitelijke situatie in kaart te brengen is voor het laatste verkiezingsjaar in de onderzoeksperiode, 1990, opnieuw een analyse uitgevoerd van de stemverhoudingen bij wethoudersverkiezingen. Anders dan in de communalistische periode is het daarnaast als gevolg van de opgetreden partijvorming mogelijk om de partijpolitieke samenstelling van de gevormde coalities te analyseren. Daarbij kan met name bekeken worden in hoeverre er sprake is van brede afspiegelingscolleges, dan wel smalle meerderheidscoalities, gelet op het zeteltal van de in het college vertegenwoordigde fracties. In dat kader wordt ook onderzocht in hoeverre de vorming van colleges op smalle basis in verband kan worden gebracht met de tegenstelling tussen lokale en

1 Deze gegevens zijn in het kader van het onderzoek van de (voomalige) Werkgroep Lokale Politiek door R. Keizers verzameld, maar nog niet eerder gepubliceerd.

2 De derde gepubliceerde case-study naar lokale politiek in Sittard (Boogers en Keizers, 1991) is in dit hoofdstuk buiten beschouwing gelaten, aangezien in Sittard de politieke verhoudingen mede werden gestempeld door deelname van de KVP (zij het niet bij alle naoorlogse verkiezingen), de PvdA en later het CDA, de VVD en enkele kleinere linkse partijen. 
landelijke lijsten. Deze gegevens worden tenslotte aangevuld met enkele op collegevorming betrekking hebbende resultaten van de mondelinge lijsttrekkersenquête. Daarbij worden de opvattingen van lijsttrekkers ten aanzien van de wenselijkheid van colleges op brede dan wel smalle basis belicht. In paragraaf 7.3. wordt tenslotte aan de hand van de enquêteresultaten de aard van de onderlinge verhoudingen in het lokaal bestuur in de vijftien steekproefgemeenten belicht.

\subsection{Collegevorming in de communalistische periode}

Het is bij onderzoek naar coalitievorming (zowel op landelijk als op lokaal niveau) gebruikelijk om de analyse primair te richten op de partijpolitieke samenstelling van executieve organen als het college van B en W. De betreffende coalities kunnen vervolgens nader gekwalificeerd worden met behulp van de in coalitievormingstheorieën ontwikkelde concepten (bv. De Swaan, 1973 en Denters, 1985). Deze benadering is echter niet hanteerbaar als de betreffende politieke partijen niet als eenheidsactoren optreden bij de coalitievorming (Tops, 1990:26).

Zoals in hoofdstuk 4 uiteen is gezet, was de organisatiegraad van individuele raadsleden in de communalistische periode in de Limburgse lokale politiek zeer laag. Landelijke partijen deden buiten enkele steden niet aan de verkiezingen mee, terwijl de lokale lijsten in de regel niet als coherente politieke organisaties kunnen worden beschouwd. Om de omvang van de steun van colleges te achterhalen is het in dat geval noodzakelijk om stemverhouding bij de wethoudersverkiezingen als graadmeter te hanteren. Op dat moment wordt de omvang van de zogenaamde legislatieve coalitie zichtbaar (Tops, 1990:27), gedefinieerd als het aantal raadsleden dat de wethouder op het moment van diens verkiezing steunde. Een onderzoek naar de omvang van de executieve coalities, dat wil zeggen de omvang van de fracties waarvan de leden van de executieve (in casu het college van B en W) deel uitmaken, is uitsluitend met betrekking tot de latere periode relevant.

\section{De omvang van legislatieve coalities}

In een steekproef van 22 Limburgse gemeenten met minder dan 15.000 inwoners ${ }^{3}$, zijn de verkiezingen van in totaal 356 wethouders in de periode 1946-1978 geînventariseerd, aan de hand van de notulen van de betreffende gemeenteraadsvergaderingen. Hoewel gelet op de selecte wijze van steekproeftrekking, gebaseerd op de bereikbaarheid en beschikbaarheid van gegevens, geen sprake is van een representatieve steekproef van alle kleine Limburgse gemeenten, is op deze wijze wel een indicatie verkregen van de omvang van legislatieve coalities in kleine Limburgse

3 Deze gemeenten zijn: Meerlo, Wanssum (vanaf 1970 Meerlo-Wanssum), Haelen, Baexem, Grathem, Heel en Panheel, Thorn, Wessem, Maasbracht, Montfort, Ohe en Laak, Grevenbicht, Obbicht, Bom, Nieuwstadt, Limbricht, Urmond, Stein, Elslo, Munstergeleen, Meerssen en Sint Geertruid. Van de gemeenten Beegden en Heel en Panheel konden geen gegevens over de wethoudersverkiezingen in 1978 niet meer worden achterhaald. 
gemeenten in de communalistische periode. De steekproef omvatte ruim 24 procent van de totale populatie Limburgse gemeenten met minder dan 15.000 inwoners in 1970.

Nagegaan is in hoeveel gevallen er sprake was van een minimale meerderheid, dat wil zeggen de helft plus één van het aantal uitgebrachte stemmen, blanco stemmen niet meegeteld. Ook situaties waarin de stemmen staakten en de wethouder door loting werd aangewezen zijn in deze categorie meegeteld. Van de overige wethoudersverkiezingen zijn vervolgens die gevallen afgezonderd, waarbij sprake was van volledige unanimiteit of bijna unanimiteit in de zin dat slechts één raadslid zich van stemming onthield dan wel tegen stemde. (In de tabel zijn deze categorieën samengevoegd en als '(bijna) unaniem' aangeduid.) Alle overige situaties zijn ondergebracht in een restcategorie ('noch unaniem, noch minimaal'). In tabel 7.1 is het resultaat van deze inventarisatie weergegeven.

Bij ruim de helft van alle verkiezingen in deze 22 gemeenten werd de keuze voor de betreffende wethouder gedragen door de kleinst mogelijke meerderheid in de gemeenteraad. Unanimiteit of bijna unanimiteit kwam slechts in zestien procent van de gevallen voor.

De hierboven gegeven indruk van de beperkte mate van consensus bij wethoudersverkiezingen in de steekproefgemeenten kan worden aangevuld door per gemeente na te gaan hoeveel steun er gemiddeld in de onderzoeksperiode aan de wethouders werd gegeven. Daartoe is voor elke gemeente het wethouderssteunpercentage berekend. Dit percentage wordt gevormd door het aantal stemmen voor de verkozen wethouder bij elke wethoudersverkiezing uit te drukken als percentage van het totaal aantal uitgebrachte stemmen (inclusief de blanco stemmen) en vervolgens het gemiddelde te berekenen van deze percentages in de betreffende gemeente over de gehele onderzoeksperiode. Tenslotte is een aan Tops ontleende onderverdeling van steekproefgemeenten in drie categorieën gehanteerd: gemeenten met een laag (kleiner of gelijk aan $66 \%$ ), een gemiddeld ( $\operatorname{van} 67 \%$ tot $85 \%$ ) en een hoog ( $86 \%$ en hoger) wethouderssteunpercentage (Tops, 1990:128). ${ }^{4}$

Uit de cijfers van tabel 7.2 blijkt dat de steun voor wethouders in de steekproefgemeenten over het algemeen als laag is te bestempelen. Twee case-studies naar lokale politiek in de gemeenten Sint-Geertruid (Custers, 1988) en Echt (Ohlenforst, 1992), bevestigen dit beeld en verschaffen bovendien inzicht in de achtergronden van deze gepolariseerde verhoudingen.

\section{Sint-Geertruid}

Typerend voor de collegevorming in de (voormalige) gemeente Sint-Geertruid is dat de lijsttrekkers er op gericht waren om een minimale meerderheid van vier van de zeven raadsleden bij wethoudersverkiezingen achter zich te krijgen. Afspiegeling in

4 De door Tops berekende wethouderssteunpercentages zijn overigens niet vergelijkbaar aangezien in deze studie de gemeenten als analyse-eenheid zijn gehanteerd en in de studie van Tops de wethoudersverkiezingen de eenheden van analyse vormen. 
Tabel 7.1. Stemverhouding bij 356 wethoudersverkiezingen in 22 kleine Limburgse gemeenten in de periode 1946-1978.

(bijna) unaniem

noch unaniem noch minimaal

minimaal

Totaal

Bron: Notulen van de betreffende gemeenteraden
$16 \%$

$30 \%$

$54 \%$

$100 \%$

(356)

Tabel 72. Gemiddelde wethouderssteunpercentages in 22 kleine Limburgse gemeenten (1946-1978).

\begin{tabular}{ll}
\hline & Limburg \\
\hline laag & $77 \%$ \\
gemiddeld & $18 \%$ \\
hoog & $5 \%$ \\
Totaal & $100 \%$ \\
& $(22)$ \\
\hline
\end{tabular}

Bron: Notulen van de betreffende gemeenteraden

het college van de krachtsverhoudingen van de diverse lijsten werd niet nagestreefd. Alle na-oorlogse colleges steunden dan ook op een minimale meerderderheid in de gemeenteraad. De strategie van de verschillende actoren vat Custers als volgt samen:

"Het enige dat telde was de persoonlijke macht die kon worden verkregen, met als logisch gevolg dat zo weinig mogelijk personen in de macht mochten delen." (Custers, 1988:62)

Aan de sterke mate van polarisatie tussen de verschillende lijsttrekkers, lagen volgens Custers veelal persoonlijke conflicten ten grondslag. In de eerste naoorlogse periode, tot circa 1958, was er in de gemeenteraad niettemin veelal sprake van eensgezindheid, behalve bij die kwesties waarbij persoonsgebonden belangen van de raadsleden zelf en van hun kiezers in het geding waren. Bij de hoofdelijke stemmingen rond dit soort onderwerpen was van een scheidslijn tussen oppositie en coalitie nauwelijks sprake; de fractie-discipline was gebrekkig.

Het optreden van standslijsten (vanaf eind jaren vijftig) zorgde voor een meer homogeen optreden van de diverse fracties. Tegelijk nam de consensus in de gemeenteraad over het te voeren beleid af. Coalitie en oppositie vormden bij stemmingen duidelijker en vaker twee tegenover elkaar staande blokken. Weinig consensus en een scherpe tegenstelling tussen een gedisciplineerd stemmende coalitie en oppositie bleven ook typerend voor de verhoudingen in de gemeenteraad in de laatste periode van Sint-Geertruid als zelfstandige gemeente, van 1970 tot 1982. 


\section{Echt}

In een beschrijving van de wijze van collegevorming in de gemeente Echt, stelt Ohlenforst dat er een stilzwijgende afspraak bestond om het aantal deelnemers aan het coalitie-overleg te beperken door alleen de grootste fracties daarbij te betrekken. Een gevolg hiervan was dat de wethouders veelal met een minimale meerderheid werden verkozen.

De fracties die de (aanvankelijk twee, sinds 1966 drie) wethouders leverden, beschikten samen vrijwel nooit over een meerderheid in de gemeenteraad. Dit hield verband met het feit dat er in Echt veel lijsten aan de verkiezingen deelnamen en de 15 (vanaf 1962 17) raadsleden verdeeld waren over gemiddeld circa 10 verschillende fracties. De scheidslijnen tussen deze fracties berustten volgens Ohlenforst, evenals in Sint-Geertruid, hoofdzakelijk op persoonlijke tegenstellingen tussen de lijsttrekkers.

Tot in de jaren zestig lijkt ook de situatie in de gemeenteraad van Echt sterk op die in Sint-Geertruid. Er was een grote mate van consensus, behalve bij kwesties waar persoonlijke belangen in het spel waren. In dit verband kunnen met name de benoeming van gemeentepersoneel en de verpachting of verkoop van gemeentegrond genoemd worden. Vanaf de jaren zeventig was er echter sprake van een toenemende polarisatie tussen een coalitie en een oppositie in de gemeenteraad, onder meer blijkend uit lange discussies tijdens de raadsvergaderingen en veel hoofdelijke stemmingen. Zowel de fractiediscipline als de discipline binnen de coalitie op basis van coalitie-beraad namen toe. De oppositie voelde zich hierdoor buiten spel gezet, hetgeen bijdroeg aan een verscherping en verharding van de politieke verhoudingen in de gemeente Echt.

\section{Gedwongen ontslag van wethouders}

Uit beide case-studies komt naar voren dat de de smalle basis van colleges in de gemeenteraad in verband moet worden gebracht met het sterk persoonsgebonden karakter van de lokale politiek. De conclusies van een onderzoek van Knippenberg naar gedwongen ontslagen van wethouders in Limburgse gemeenten sluiten hierbij aan (Knippenberg, 1988).

In Limburgse gemeenten is in vergelijking met andere provincies relatief vaak gebruik gemaakt van de bevoegdheid van de gemeenteraad om wethouders tussentijds te ontslaan (ex art. 87a gemeentewet). Dertig procent van de door Bense voor heel Nederland in kaart gebrachte ontslagen vond plaats in Limburg (Bense, 1983:85). In totaal is sinds de invoering van art. 87a gemeentewet (in 1948) tot 1986 in 24 Limburgse gemeenten 39 keer gebruik gemaakt van deze bevoegdheid (Knippenberg, 1988). Van deze 39 ontslagbesluiten werden er 35 genomen in gemeenteraden met uitsluitend raadsleden die op lokale lijsten hadden gekandideerd. In de overige vier situaties was er een meerderheid in de raad voor dit type lijsten.

$\mathrm{Bij}$ een nadere analyse van twintig van deze ontslag-kwesties in de jaren zeventig en begin jaren tachtig, bleek dat 85 procent van de wethouders die met een ontslagprocedure werden geconfronteerd, door een minimale raadsmeerderheid waren verkozen. Het voorstel tot ontslag werd eveneens gewoonlijk met de kleinst mogelijke meerderheid aanvaard. Vaak kwam de ontslagprocedure voort uit het 'overlopen' van 
één raadslid, van de ene coalitie naar de andere. Daardoor sloeg de krappe meerderheid voor één of meerdere zittende wethouders om in een minderheid.

Naar aanleiding van een inhoudsanalyse van de betreffende gemeenteraadsnotulen stelt Knippenberg vast dat de motieven voor dit overlopen veelvuldig in de persoonlijke sfeer lagen. Hij concludeert dat:

“..er sprake was van diepgewortelde tegenstellingen, die samenwerking in een college op brede basis ten enenmale onmogelijk maken." (Knippenberg, 1988:8)

\subsection{Collegevorming in de periode $1982-1990$}

De omvang van legislatieve coalities

Een eerste aanwijzing voor de mogelijke veranderingen in de hiervoor geschetste situatie als gevolg van de komst van landelijke partijen in de Limburgse lokale politiek, vormt een analyse van de omvang van legislatieve coalities aan het eind van de onderzoeksperiode 5 .

Op basis van een opgave van de Limburgse gemeenten is een berekening gemaakt van de mate waarin de in 1990 (en in een aantal geherindeelde gemeenten begin 1991) verkozen wethouders in deze gemeenten gesteund werden door raadsleden op het moment van hun verkiezing.

Evenals in de vorige paragraaf zijn de gemeenten verdeeld over drie categorieën op basis van de omvang van het wethouderssteunpercentage: laag (kleiner of gelijk aan $66 \%$ ), gemiddeld (van $67 \%$ tot $85 \%$ ) en hoog $(86 \%$ en hoger) 6 .

In een meerderheid van de gemeenten blijken de wethouders op een gemiddelde tot hoge mate van steun in de raad te kunnen rekenen. Zie tabel 7.3. Uit deze tabel spreekt een grotere mate van steun voor wethouders dan uit tabel 7.2 die betrekking had op de communalistische periode. Daarbij moet echter bedacht worden dat de beide populaties niet zonder meer vergelijkbaar zijn, aangezien de gegevens van tabel 7.2 slechts betrekking hebben op de situatie in een steekproef van 22 kleine Limburgse gemeenten. Deze gegevens kunnen slechts beschouwd worden als een eerste aanwijzing voor een toename van de steun voor colleges ten opzichte van de communalistische periode.

\section{De omvang van executieve coalities}

Bij het in kaart brengen van de omvang van de in de Limburgse lokale politiek voorkomende executieve coalities is een door Tops ontwikkelde methode toegepast (Tops, 1990:95 e.v.). Daarbij wordt in eerste instantie een onderscheid gemaakt tussen

5 Gegevens over eerdere verkiezingsjaren zijn niet voorhanden.

6 In de gemeente Echt verlieten zeven raadsleden uit protest de vergadering, vlak voor de wethoudersverkiezingen. Overeenkomstig de definitie van het wethouderssteunpercentage zou deze gemeente in de categorie 'hoog' vallen gelet op het feit dat de overblijvende negen raadsleden unaniem voor de wethouders stemden. In dit specifieke geval zijn de zeven niet-stemmers echter als tegenstemmers aangemerkt, hetgeen een reëler beeld geeft van de steun voor de wethouders in de betreffende situatie. 
Tabel 73. Gemiddelde wethouderssteunpercentages in Limburgse gemeenten (1990).

\begin{tabular}{ll}
\hline & Limburg \\
\hline laag & $43 \%$ \\
gemiddeld & $28,5 \%$ \\
hoog & 28,5 \\
Totaal & $100 \%$ \\
& $(56)$ \\
\hline
\end{tabular}

Bron: CELS-bestand (op basis van opgaven gemeenten)

Tabel 7.4. Afspiegelings en niet-af spiegelingscolleges in Limburgse gemeenten, 1982-1990.

\begin{tabular}{lccc}
\hline & 1982 & 1986 & 1990 \\
\hline afspiegeling & $73 \%$ & $72 \%$ & $59 \%$ \\
niet-afspiegeling & $27 \%$ & $28 \%$ & $41 \%$ \\
Totaal & $100 \%$ & $100 \%$ & $100 \%$ \\
& $(69)$ & $(69)$ & $(56)$ \\
\hline
\end{tabular}

Bron: CELS-bestand (op basis van opgaven gemeenten)

afspiegelings- en niet-afspiegelingscolleges. Van afspiegeling is sprake indien alle partijen die volgens de methode van de grootste gemiddelden recht hebben op een wethouderszetel, deel uitmaken van het college. In alle andere gevallen is sprake van niet-afspiegeling. Dit houdt in dat het bij afspiegeling uitgesloten is dat een kleinere fractie wel en een grotere fractie niet een wethouderszetel levert. Het afspiegelingscollege is te beschouwen als een 'grote' coalitie ofwel een college dat op een 'brede basis' in de gemeenteraad steunt.

In tabel 7.4 is het aantal in Limburg gevormde afspiegelingscolleges in de periode 1982-19907 zichtbaar gemaakt. Een ruime meerderheid van de in de onderzoeksperiode tot stand gekomen colleges voldeed aan het afspiegelingscriterium. In 1990 was sprake van een duidelijke stijging van het aantal niet-afspiegelingscolleges.

Om verschillende redenen kunnen aan de hand van deze tabel echter nog geen conclusies getrokken worden over de mate waarin de afspiegelingsregel een belangrijke rol speelt bij collegevorming in Limburgse gemeenten.

Tops heeft er terecht op gewezen dat een afspiegelingscollege niet altijd hoeft voort te komen uit het bewuste streven van de plaatselijke politici om bij de collegevorming

7 Inclusief de na de verkiezingen van 29 november 1990 in Midden-Limburg gevormde colleges, die formeel pas in 1991 werden geïnstalleerd. Waar in het vervolg van dit hoofdstuk sprake is van de collegevorming in 1990 wordt de Middenlimburgse collegevorming in 1990-91 daar tevens toe gerekend. 
recht te doen aan de politieke verhoudingen in de gemeenteraad (Tops, 1990:102). De gevormde coalitie kan ook een min of meer gedwongen afspiegelingskarakter hebben, indien alleen bij deze samenstelling van het college een meerderheid voor de coalitie in de gemeenteraad zou ontstaan. Het is in dat geval onduidelijk of er sprake is van een bewuste keuze van partijen voor hantering van de afspiegelingsnorm, er vanuit gaande dat men minderheidscolleges zoveel mogelijk wil voorkomen.

Deze situatie komt vooral veel voor in kleine gemeenten. Wanneer de gemeenteraad bijvoorbeeld uit zeven leden bestaat die in drie tweemansfracties en één éénmansfractie zijn onderverdeeld (2-2-2-1), dan is de enige mogelijkheid om een meerderheidscollege te vormen, een college dat bestaat uit wethouders van twee tweemans-fracties. Datzelfde college voldoet automatisch aan de afspiegelingsregel. In dit geval is het echter mogelijk dat de betrokkenen niet primair afspiegeling nastreefden, maar eerder gericht waren op de vorming van een zo klein mogelijke meerderheid (4-3). Met het oog op dit soort situaties is het dan ook zinvol om een nader onderscheid te maken tussen afspiegelingscolleges met een, gegeven de politieke verhoudingen in de raad, min of meer gedwongen karakter, en afspiegelingscolleges waarvoor bewust gekozen is, ondanks dat colleges met een smallere basis ook op een meerderheid in de raad zouden kunnen rekenen.

Een bijzondere vorm van gedwongen afspiegeling doet zich voor indien één fractie niet alleen de meerderheid in de raad heeft, maar bovendien op grond van de afspiegelingsregel aanspraak kan maken op alle wethouderszetels, bijvoorbeeld bij een verhouding 4-2-1. Echter, wanneer naast de meerderheidsfractie toch een andere fractie een wethouder levert, is er sprake van 'gekozen' afspiegeling. De meerderheidsfractie heeft er in dat geval kennelijk voor gekozen om de macht met een andere fractie te delen, zodat dan moeilijk van een gedwongen afspiegeling kan worden gesproken 8 .

Een derde te onderscheiden categorie afspiegelingscolleges wordt gevormd door die colleges, waarbij de fracties die de wethouders leveren niet beschikken over een meerderheid in de gemeenteraad.

In tabel 7.5 is deze nadere onderverdeling van de in Limburg gevormde afspiegelingscolleges in de betreffende periode, in de drie genoemde categorieën weergegeven. Uit dit overzicht blijkt dat een derde van alle afspiegelingscolleges tot stand is gekomen in een situatie waarin alleen die coalitie over een meerderheid in de raad kon beschikken. Er is sprake van een relatieve afname van het aantal gedwongen afspiegelingscolleges, zowel in 1986, als in 1990.

De niet-afspiegelingscolleges worden door Tops voorts nog onderscheiden in minderheidscolleges, colleges die berusten op een minimale meerderheid (de helft plus énn) in de raad en colleges die op een ruimere meerderheid steunen.

In tabel 7.6 is deze onderverdeling van in Limburg in de periode 1982-1990 gevormde niet-afspiegelingscolleges gegeven.

8 Het is dan ook ons inziens ten onrechte dat Tops deze categorie wel als gedwongen afspiegeling aanduidt (Tops, 1990: 102, 170). 
Tabel 7.5. Verschillende soorten afspiegelingscolleges in Limburgse gemeenten, 1982-1990.

\begin{tabular}{llll}
\hline & 1982 & 1986 & 1990 \\
\hline keuze & $50 \%$ & $59 \%$ & $61 \%$ \\
gedwongen & $38 \%$ & $29 \%$ & $21 \%$ \\
minderheid & $12 \%$ & $12 \%$ & $18 \%$ \\
Totaal & $100 \%$ & $100 \%$ & $100 \%$ \\
& $(50)$ & $(49)$ & $(33)$ \\
\hline
\end{tabular}

Bron: CELS-bestand (op basis van opgaven gemeenten)

Tabel 7.6. Soorten niet-afspiegelingscolleges in Limburgse gemeenten, 1982-1990.

\begin{tabular}{llll}
\hline & 1982 & 1986 & 1990 \\
\hline niet-minimaal & $42 \%$ & $40 \%$ & $65 \%$ \\
minimaal & $21 \%$ & $20 \%$ & $9 \%$ \\
minderheid & $37 \%$ & $40 \%$ & $26 \%$ \\
Totaal & $100 \%$ & $100 \%$ & $100 \%$ \\
& $(19)$ & $(20)$ & $(23)$ \\
\hline
\end{tabular}

Bron: CELS-bestand (op basis van opgaven gemeenten)

Tabel 7.7. Soorten in Limburgse gemeenten gevormde colleges, 1982-1990.

\begin{tabular}{lccc}
\hline & 1982 & 1986 & 1990 \\
\hline Afspiegeling: & & & \\
keuze & $36 \%$ & $42 \%$ & $36 \%$ \\
gedwongen & $28 \%$ & $21 \%$ & $11 \%$ \\
minderheid & $9 \%$ & $9 \%$ & $12 \%$ \\
sub-totaal & $73 \%$ & $72 \%$ & $59 \%$ \\
Niet-afspiegeling: & & & \\
niet-minimaal & $11 \%$ & $11 \%$ & $27 \%$ \\
minimaal & $6 \%$ & $6 \%$ & $3 \%$ \\
minderheid & $10 \%$ & $11 \%$ & $11 \%$ \\
sub-totaal & $27 \%$ & $28 \%$ & $41 \%$ \\
& $100 \%$ & $100 \%$ & $100 \%$ \\
Totaal & $(69)$ & $(69)$ & $(56)$ \\
& & & \\
\hline
\end{tabular}

Bron: CELS-bestand (op basis van opgaven gemeenten) 
Opvallend is het geringe en afnemende aantal niet-afspiegelingscolleges, dat op een minimale meerderheid in de gemeenteraad berustte.

De gegevens van de tabellen 7.5 en 7.6 leveren bij elkaar opgeteld, de in tabel 7.7 weergegeven verdeling van Limburgse colleges over de zes hiervoor onderscheiden categorieën op.

In de periode 1982-1990 nam het percentage gedwongen afspiegelingscolleges af, terwijl het percentage niet-afspiegelingscolleges met een niet-minimale meerderheid in de raad in 1990 sterk is toegenomen. Het percentage minderheidscolleges bleef min of meer constant rond de twintig procent. De gekozen afspiegelingscolleges vormden in alle drie verkiezingsjaren de grootste categorie. Dit levert opnieuw een aanwijzing op voor de tamelijk brede steun voor de gevormde coalities.

\section{Partij-politieke samenstelling van niet-afspiegelingscolleges}

Uit een analyse van de politieke samenstelling van niet-afspiegelingscolleges kan worden afgeleid of zich conflictpatronen tussen de verschillende partijen voordeden, die als verklaring kunnen worden aangevoerd voor het buiten de coalitie houden van bepaalde lijsten, die op grond van de omvang van hun fracties volgens de afspiegelingsregel wel in aanmerking zouden komen voor een wethouderszetel. Daarbij kan naast de in de inleiding gesuggereerde tegenstelling tussen lokale en landelijke lijsten ook gedacht worden aan een tegenstelling tussen confessionele en niet-confessionele landelijke partijen.

In tabel 7.8 is te zien welke politieke samenstelling de betreffende niet-afspiegelingscolleges ${ }^{9}$ hadden, gerelateerd aan het type lijst dat buiten het college werd gehouden.

In de meeste gevallen, namelijk 29 van de 54, blijken het lokale lijsten te zijn geweest, die in afwijking van de afspiegelingsnorm buiten de colleges zijn gehouden. Het CDA hield in combinatie met of wel andere landelijke lijsten, of wel samen met éen of meer lokale lijsten, 25 keer een lokale lijst in afwijking van de afspiegelingsregel buiten de coalitie. Zelf werd het CDA in 16 coalities buitengesloten. In 14 gevallen was bij deze coalities ook een lokale lijst betrokken.

Dit duidt op enige mate van polarisatie tussen het CDA en de grote plaatselijke politieke groeperingen in de betreffende gemeenten. Zestig procent van het totale aantal gevormde niet-afspiegelingscolleges in de periode 1982-1990 is hiermee in verband te brengen.

Een tweede tegenstelling die uit het onderzoek naar de politieke samenstelling van niet-afspiegelingscolleges naar voren komt, was die tussen CDA enerzijds en nietconfessionele landelijke lijsten - met name de PvdA - anderzijds. Deze tegenstelling werd bij 11 niet-afspiegelingscolleges zichtbaar, ofwel bijna twintig procent van het totaal.

9 Met uitzondering van acht niet-afspiegelingscolleges die gevormd werden vanuit raden waarin uitsluitend lokale lijsten vertegenwoordigd waren, zangezien deze niet in verband te brengen zijn met é́n van de genoemde tegenstellingen. 
Tabel 7.8. Politieke samenstelling van in Limburgse gemeenten gevormde niet-afspiegelingscolleges, 1982-1990.

\begin{tabular}{llc}
\hline Collegepartijen & Buitengesloten lijst & Aantal \\
\hline Landelijke lijsten & Lokale lijst & 18 \\
CDA + Lokale lijst(en) & Lokale lijst & 7 \\
Lokale lijsten & Lokale lijst & 4 \\
sub-totaal & & 29 \\
& CDA & 8 \\
Lokale lijsten & CDA & 4 \\
PrdA/VVD + Lokale lijst & CDA & 2 \\
PvdA + VVD & CDA & 2 \\
PvdA + D66 + Lokale lijst & & 16 \\
sub-totaal & PvdA/PAK & 3 \\
CDA & VVD & 3 \\
CDA + PvdA & & 3 \\
Overige combinaties & & \\
Totaal & & 54 \\
\hline
\end{tabular}

Bron: CELS-bestand (op basis van opgaven gemeenten)

Het belang van deze scheidslijnen in de Limburgse lokale politiek moet echter gerelativeerd worden op grond van het feit dat de hiervoor aangeduide rivalen in veel andere gemeenten wel samen een college vormden. Coalities tussen CDA en PvdA kwamen in de periode 1982-1990 56 keer voor; coalities tussen het CDA en de grootste lokale lijst in de betreffende gemeente, werden 61 keer gevormd. Van een systematische uitsluiting van bepaalde typen lijsten in de Limburgse lokale politiek was in deze periode over het algemeen geen sprake. De tegenstellingen tussen lokale en landelijke lijsten en tussen confessionele en niet-confessionele landelijke lijsten stonden in de regel de vorming van afspiegelingscolleges in Limburgse gemeenten niet in de weg.

Mate van consensus over afspiegeling als norm

Uit het voorgaande kan echter niet zonder meer afgeleid worden dat met de introduktie van landelijke partijen nu cok in de Limburgse lokale politiek de afspiegelingsnom stevig geworteld is. Wanneer de analyse van collegevorming op het niveau van de individuele gemeenten wordt gebracht, kan bekeken worden in hoeveel gemeenten in alle verkiezingsjaren in de onderzoeksperiode consequent afspiegelingscolleges zijn gevormd.

In tabel 7.9 zijn de Limburgse gemeenten ingedeeld op grond van het soort colleges dat in de periode 1982-1990 tot stand is gekomen. Gelet op de gemeentelijke herindeling in Midden-Limburg in 1990, heeft het onderzoek alleen betrekking op de Noord- 
Tabel 7.9. Limburgse gemeenten* naar het aantal keren dat de betreffende colleges voldeden aan de afspiegelingsnorm in de periode 1982-1990.

\begin{tabular}{ll}
\hline Aantal keren afspiegelingscolleges & Aantal gemeenten \\
\hline geen & $7 \%$ \\
én keer & $27 \%$ \\
twee keer & $31 \%$ \\
drie keer & $35 \%$ \\
Totaal & $100 \%$ \\
& $(49)$ \\
\hline
\end{tabular}

* Met uitzondering van: Haelen, Heel, Heythuysen, Maasbracht, Melick c.a., Posterholt en Roggel. Bron: CELS-bestand (op basis van opgaven gemeenten)

en Zuidlimburgse gemeenten, alsmede die Middenlimburgse gemeenten waar slechts sprake was van beperkte grenscorrecties ${ }^{10}$. In totaal gaat het daarbij om 49 gemeenten.

Uit deze gegevens blijkt dat de afspiegelingsnorm in ongeveer een derde van de Limburgse gemeenten dusdanig sterk geworteld was, dat er in de periode 1982-1990 geen enkele keer van werd afgeweken. Wij concluderen hieruit dat het in de rest van Nederland gangbare patroon van collegevorming op basis van afspiegeling in Limburgse gemeenten wel op tamelijk grote schaal is overgenomen maar nog niet als een bijna absolute norm ingang heeft gevonden.

Aan deze gegevens kan worden toegevoegd dat uit de lijsttrekkersenquête bleck dat de meeste respondenten wel een voorkeur hadden voor colleges met een brede basis. (Aangezien de term afspiegeling wellicht bij een aantal respondenten tot verwarring zou kunnen leiden is gekozen voor de terminologie 'brede basis' versus 'smalle basis'.)

De mate waarin de 78 tot raadslid verkozen respondenten een voorkeur hadden voor een college op brede dan wel smalle basis is in tabel 7.10 weergegeven. Daarbij zijn de respondenten uitgesplitst naar type lijst.

De voorkeur van een ruime meerderheid van de respondenten in beide categoricën ging uit naar een college op brede basis. Het is daarbij opvallend dat de respondenten van lokale lijsten zelfs nog een grotere consensus over de wenselijkheid van grote coalities vertoonden dan de respondenten van landelijke lijsten. Van de elf respondenten van landelijke lijsten die een voorkeur uitspraken voor een college op smalle basis, behoorden er negen tot de linkerzijde van het politieke spectrum (PvdA en kleinere linkse partijen). De CDA- en VVD-respondenten waren wel vrijwel unaniem in hun voorkeur voor brede coalities.

Ondanks deze over het algemeen positieve attitude ten aanzien van colleges op brede basis kan men constateren dat in de praktijk het aantal gevormde niet-afspiegelingscolleges nog tamelijk groot was. Niettemin is er sprake van een scherp contrast

10 Het betreft de gemeenten Echt, Hunsel, Nederweert, Roermond, Stramproy, Swalmen, Thom en Weert 
Tabel 7.10. Voorkeur van lijsttrekkers ten aanzien van de samenstelling van het college, naar type lijst.

\begin{tabular}{llll}
\hline & $\begin{array}{l}\text { Lokale } \\
\text { lijsten }\end{array}$ & $\begin{array}{l}\text { Landelijke } \\
\text { lijsten }\end{array}$ & Totaal \\
\hline smalle basis & $14 \%$ & $31 \%$ & $22 \%$ \\
brede basis & $76 \%$ & $64 \%$ & $71 \%$ \\
geen vourkeur & $10 \%$ & $5 \%$ & $7 \%$ \\
Totad & $100 \%$ & $100 \%$ & $100 \%$ \\
& $(42)$ & $(36)$ & $(78)$ \\
\hline
\end{tabular}

$\mathrm{chi}^{2}=3,52$; (niet-sign.)

Bron: Lijsttrekkersenquête. RL

met de situatie zoals die uit de op de communalistische periode betrekking hebbende case-studies naar voren $\mathrm{kwam}$.

\subsection{Verhoudingen binnen het lokaal bestuur}

Uit de in de eerste paragraaf besproken onderzoeksgegevens komt voor de communalistische periode een beeld naar voren van tamelijk sterke tegenstellingen in de raden van veel Limburgse gemeenten met name op het moment van collegevorming. In de periode 1982-1990 lijkt echter in de meeste gemeentebesturen sprake te zijn van meer harmonische verhoudingen. Aan de hand van de resultaten van de mondelinge lijsttrekkersenquête kan de situatie in vijftien gemeenten in de periode 1982-1986 nader onder de loupe worden genomen.

Over dit onderwerp zijn uitsluitend de 78 respondenten die als raadslid fungeerden in de periode 1982-1986 ondervraagd. Lijsttrekkers die zonder succes aan de verkiezingen deeinamen worden geacht te ver van de dagelijkse praktijk van de lokale politiek af te staan om een betrouwbare evaluatie hiervan te kunnen maken.

Voor wat betreft de onderlinge verhoudingen binnen het gemeentebestuur is de volgende vraag in de enquête opgenomen: "Ik wil u nu iets vragen over de verhouding tussen de verschillende instanties die samen het gemeentebestuur vormen. Dat kan van gemeente tot gemeente nogal verschillen. Soms is er sprake van eensgezinde samenwerking, soms is het meer een proces van geven en nemen, soms is er sprake van regelmatige conflicten. Hoe zou u de verhoudingen in (naam gemeente) in de periode 1982-1986 willen omschrijven?"

Aan de respondenten werd vervolgens een kaart getoond met daarop vijf verhoudingen, te weten:

- verhouding tussen burgemeester en gemeenteraad;

- verhouding tussen burgemeester en wethouders onderling;

- verhouding tussen wethouders en gemeenteraad; 
Tabel 7.11. Percepties van lijsttrekkers van de verhoudingen tussen actoren in de eigen gemeente, in de periode 1982-1986.

\begin{tabular}{llllll}
\hline & \multicolumn{2}{l}{ Verhouding } & & & \\
\cline { 2 - 6 } & $\mathrm{A}$ & $\mathrm{B}$ & $\mathrm{C}$ & $\mathrm{D}$ & $\mathrm{E}$ \\
\hline eensgezinde samenwerking & $35 \%$ & $59 \%$ & $39 \%$ & $15 \%$ & $47 \%$ \\
geven en nemen & $44 \%$ & $32 \%$ & $39 \%$ & $46 \%$ & $31 \%$ \\
regelmatige conflicten & $21 \%$ & $9 \%$ & $22 \%$ & $39 \%$ & $22 \%$ \\
Totaal & $100 \%$ & $100 \%$ & $100 \%$ & $100 \%$ & $100 \%$ \\
geen antwoord & $(77)$ & $(71)$ & $(77)$ & $(76)$ & $(74)$ \\
\hline
\end{tabular}

$A=$ tussen burgemeester en gemeenteraad; $B=$ tussen burgemeester en wethouders onderling; $C=$ tussen wethouders en gemeenteraad; $D=$ tussen raadsfracties onderling; $E=$ tussen wethouders en eigen fracties.

Bron: Lijsturekkersenquête, RL

- verhouding tussen raadsfracties onderling;

- verhouding tussen wethouders en eigen fracties.

De antwoorden van de respondenten gezamenlijk zijn weergegeven in tabel 7.11. Uit deze tabel blijkt dat de verhoudingen binnen de diverse colleges van burgemeester en wethouders volgens de meeste respondenten harmonisch was. Als minder soepel werd de relatie tussen burgemeester en raad becordeeld. De burgemeester slaagde er, ondanks zijn positie als min of meer boven de partijen staande actor, volgens de meeste respondenten kennelijk niet in om een eensgezinde samenwerking met de raad te verkrijgen.

Ook in de relatie tussen wethouders en raad en tussen wethouders en de eigen raadsfracties was vaak geen sprake van eensgezinde samenwerking. De meest gepolariseerde relatie lijkt die tussen de raadsfracties onderling te zijn.

Wanneer de respons per gemeente wordt bekeken, dan valt ten aanzien van de verhoudingen binnen de colleges op dat er weliswaar in zes gemeenten regelmatige conflicten werden gemeld, maar telkens door slechts één respondent. In negen gemeenten was er volgens een duidelijke meerderheid van de respondenten sprake van eensgezinde samenwerking binnen het college.

In niet meer dan twee steekproefgemeenten vond daarentegen het merendeel van de respondenten dat de burgemeester eensgezind met de gemeenteraad samenwerkte. De respondenten van de vijf gemeenten met minder dan 10.000 inwoners karakteriseerden de relatie tussen de raad en haar voorzitter vrijwel unaniem als 'geven en nemen'. Slechts in eén gemeente deden zich volgens de meeste respondenten regelmatig conflicten voor tussen burgemeester en gemeenteraad.

In zes van de vijftien gemeenten sprak meer dan één respondent van regelmatige conflicten tussen wethouders en de eigen raadsfracties. Een grote mate van eensgezindheid tussen wethouders en eigen fracties lijkt slechts in een viertal gemeenten te 
Tabel 7.12. Percepties van lijsttrekkers van de stemverhoudingen in de eigen gemeenteraad, in de periode 1982-1986.

\begin{tabular}{lr}
\hline eensgezindheid & $19 \%$ \\
twee blokken & $67 \%$ \\
drie of meer blokken & $5 \%$ \\
geen vast stempatroon & $9 \%$ \\
& $100 \%$ \\
Totaal & $(78)$ \\
\hline
\end{tabular}

Bron: Lijsttrekkersenquête, RL

hebben bestaan. Overigens was er juist bij dit onderdeel nogal wat verschil in perceptie tussen lijsttrekkers uit dezelfde gemeente.

Om te achterhalen in hoeverre er in de steekproefgemeenten sprake was van een tegenstelling tussen oppositie en coalitie, is voorts gevraagd naar de stemverhoudingen binnen de gemeenteraad. De respondenten werd verzocht aan te geven welke van een aantal op een kaart gespecificeerde situaties in hun gemeenteraad bij stemmingen over belangrijke kwesties in de periode 1982-1986 het meeste voorkwam.

De aangegeven situaties waren:

1. bij belangrijke kwesties werden de leden het gewoonlijk eens en stemde men op dezelfde wijze;

2. bij belangrijke kwesties splitste de raad zich gewoonlijk op in twee blokken die tegenover elkaar stonden;

3. bij belangrijke kwesties viel de raad gewoonlijk uiteen in drie of meer blokken met verschillende opvattingen;

4. bij belangrijke kwesties viel er gewoonlijk geen vast patroon te ondekken in het stemgedrag van raadsleden.

De betreffende respons is in tabel 7.12 weergegeven. Ook bij dit onderdeel is de respons per steekproefgemeente geanalyseerd. In tien gemeenten werd het uiteenvallen van de raad in twee blokken door een duidelijke meerderheid van de lijsttrekkers als de dominante situatie aangeduid. In drie kleine gemeenten lijkt de raad in hoge mate eensgezind te zijn geweest in de betreffende periode. De respons uit de overige twee gemeenten liep te zeer uiteen om een eenduidige conclusie te kunnen trekken.

\section{Samenvatting}

De relaties tussen de verschillende actoren in de meeste van de vijftien steekproefgemeenten werden grosso modo met 'geven en nemen' getypeerd. Binnen de colleges van $B$ en W was volgens de respondenten in de betreffende periode (1982-1986) vaak sprake van eensgezindheid. Bij de verhoudingen tussen de raadsfracties onderling en russen wethouders en de gemeenteraad signaleerde een groter aantal respondenten regelmatige conflicten. Deze conflicten kunnen in tweederde van de steekproefgemeenten in verband worden gebracht met het uiteenvallen van de gemeenteraad in twee blokken. 
Deze gegevens ondersteunen het tamelijk harmonische beeld dat de kwantitatieve analyse van de collegevorming in Limburgse gemeenten in de periode 1982-1990 opriep.

\subsection{Achtergronden van de collegevorming in Limburgse gemeenten}

De in Nederlandse gemeenten gevormde colleges van B en W vormen, zoals in de inleiding is gesteld, qua partijpolitieke samenstelling in de regel een afspiegeling van de getalsmatige verhoudingen in de betreffende gemeenteraad. Op het moment waarop heel nadrukkelijk de verdeling van macht over de verschillende partijen aan de orde is, ontstaan in de meeste gevallen geen gepolariseerde onderhandelingssituaties, maar wordt gebruik gemaakt van een rekenkundig criterium, de afspiegelingsnorm, om de wethouderszetels over de grootste fracties te verdelen.

Deze wijze van collegevorming kan in verband gebracht worden met de ook op lokaal niveau van oudsher verzuilde partijstructuur (bv. Tops en Korsten, 1984:13$15)$, waarbij structurele minderheden gedwongen werden tot een vorm van samenwerking die bekend staat als de pacificatiedemocratie (Lijphart, 1979). Om te voorkomen dat (potentiële) machts- en belangenconflicten escaleerden, was er voor die samenwerking behoefte aan objectieve normen voor de verdeling van machtsposities. Deze zorg vormde de aanleiding tot het onderdrukken van de op zich natuurlijke neiging om bij de collegevorming het onderste uit de kan te halen.

In de provincie Limburg waren de aan de traditionele zuilen gebonden partijen echter (buiten enkele grote steden) lange tijd afwezig op lokaal niveau. De katholieke zuil verkeerde in een riante en naar het leek onaantastbare meerderheidspositie in de Limburgse samenleving. Voor de plaatselijke politici was er wat dat betreft dus geen aanleiding om bij de collegevorming een strategie te volgen waarbij werd afgezien van maximalisering van de op korte termijn te behalen opbrengsten.

Tops heeft in navolging van met name de coalitievormingstheorieën van Budge en Laver, een op Nederlandse gemeenten toegespitste structuur van opbrengsten en kosten van maximaliserend gedrag bij collegevorming ontworpen, aan de hand waarvan zowel de bestendigheid van afspiegelingscolleges na de periode van verzuiling, (Tops, 1990), als de afwijkende situatie in Limburg nader geanalyseerd kan worden (Kuiper en Tops, 1989).

Daarbij wordt een onderscheid gemaakt tussen de direkt aan de verwerving van een wethouderszetel verbonden baten in de vorm van status en prestige, en de afgeleide opbrengsten in termen van invloed op het beleid en mogelijk electoraal gewin bij volgende verkiezingen. Als kosten van een maximaliserende strategie noemt Tops met name de hoge besluitvormingskosten bij minimale meerderheden en het risico dat een partij die andere partijen bij coalitievorming uitsluit, een risico loopt om zelf vier jaar later te worden buitengesloten. Het streven naar continue deelname aan de coalitie vormt in dat kader een rem op de neiging om de genoemde opbrengsten te maximaliseren $^{11}$. 
In de sterk op de persoon van de politicus gerichte politieke cultuur in Limburgse gemeenten, kan men veronderstellen dat deze opbrengsten van het wethoudersambt door de meeste politici hoog werden ingeschat. Geen wethouder worden of niet betrokken worden bij de coalitie betekende bij cliëntelistische verhoudingen dat de eigen kiezers minder goed bediend konden worden. Het betekende bovendien minder publieke en publicitaire aandacht voor de eigen persoon en daardoor waarschijnlijk ook een verminderde wervingskracht bij volgende verkiezingen. Deze overwegingen gaven aanleiding tot een sterke impuls voor het voeren van een maximaliserende strategie bij collegevorming. De tamelijk geringe mate van steun aan colleges in de communalistische periode zijn op deze manier verklaarbaar.

\section{Gevolgen van nationalisering}

De intrede van landelijke lijsten in de Limburgse lokale politiek en de toenemende organisatie van politieke groeperingen kunnen moeilijk geacht worden invloed te hebben gehad op de omvang of aard van de direkt aan de wethouderszetels verbonden opbrengsten. Dit ligt anders bij de met het verkrijgen van een plaats in de coalitie te verwerven opbrengsten in termen van het te voeren gemeentelijk beleid.

De nationalisering kan geacht worden een meer politiek-ideologische benadering van lokaal bestuur met zich mee te brengen, waardoor de beleidsinhoudelijke conflicten deels van karakter zijn veranderd. Gelet op de inhoud van het gemeentelijk beleid en de omvang van de gemeentelijke beleidsvrijheid, lijkt er echter in politiek-ideologisch opzicht nauwelijks aanleiding te zijn om éen van de politieke hoofdstromingen uit te sluiten en te kiezen voor een maximalistische strategie (Tops, 1990:192). Uit de analyse van de partijpolitieke samenstelling van Limburgse colleges blijken de voor de hand liggende scheidslijnen tussen confessionele en niet-confessionele partijen en tussen landelijke en lokale lijsten inderdaad betrekkelijk zelden aanleiding te zijn tot de vorming van niet-afspiegelingscolleges. Wanneer de politiek-ideologisch getinte conflicten de boventoon gaan voeren is het te verwachten dat de ruimte voor beleidsopbrengsten en de daaruit voortvloeiende neiging tot maximaliserend coalitie-gedrag afneemt.

Het gewicht van mogelijke electorale opbrengsten wordt verondersteld af te nemen, naarmate meer kiezers zich bij gemeenteraadsverkiezingen laten leiden door politieke ontwikkelingen op landelijk niveau. Immers, in dat geval heeft het gedrag van de politicus, dan wel diens partij, steeds minder invloed op de keuze van de kiezer. Waar aan deze factor in de communalistische periode een groot belang kan worden toegeschreven, zal bij genationaliseerde politieke verhoudingen sprake zijn van een afnemende invloed hiervan op het coalitiegedrag van de verschillende actoren, zodat ook deze impuls voor maximaliserend coalitiegedrag aan belang zal inboeten.

De besluitvormingskosten van kleine coalities vormen in beide perioden een rem op maximalistisch gedrag. De angst voor repurcussies bij een volgende coalitievorming zal echter met name groot zijn in een situatie waarbij sprake is van een min of meer

11 Een dergelijke vorm van het afzien van opbrengstenmaximalisering is door Elster bestempeld als de onder bepaalde omstandigheden rationele strategie van 'zelf-binding' (Elster, 1979). 
uitgekristalliseerd partijsysteem. Het veronderstelt een optreden van op continue machtsuitoefening gerichte politieke organisaties naast individuele politici als actoren bij de collegevorming. Aan deze condities werd in de communalistische periode niet voldaan.

De geleidelijke stabilisering van de lokale politieke systemen in Limburg die sindsdien is opgetreden (zie hoofdstuk 3), brengt met zich mee dat dit risico van maximaliserend gedrag aan het eind van de onderzoeksperiode zwaarder gevoeld zal worden. Dit vormt mede een verklaring voor het feit dat ook de meerderheid van de lijsttrekkers van lokale lijsten een positieve attitude ten aanzien van colleges op brede basis vertoonden.

Tegen de achtergrond van deze ontwikkelingen in de structuur van opbrengsten en kosten van verschillende vormen van coalitiegedrag verwachten wij een verdere toename van de consensus over de wenselijkheid van afspiegelingscolleges en een nog veelvuldiger hantering van de afspiegelingsnorm bij collegevorming in Limburgse gemeenten. 



\section{Hoofdstuk 8}

\section{Samenvatting en conclusie}

Deze studie beoogt inzicht te geven in de ontwikkelingen in de Limburgse lokale politiek in de afgelopen vijftien jaar. In deze periode heeft zich een proces van nationalisering voltrokken waardoor aan de van oudsher vrijwel afwezigheid van landelijke lijsten bij Limburgse gemeenteraadsverkiezingen een eind is gekomen. Om een goed inzicht te verkrijgen in de politieke ontwikkelingen werd het wenselijk geacht om deze te plaatsen in de bredere context van de maatschappelijke ontwikkelingen die zich in de provincie Limburg hebben voorgedaan. Vervolgens is het onderzoek met name gericht op de aard en de manier van functioneren van lokale lijsten, op de binding tussen kiezers en politici, op de kenmerken van politieke leiders in relatie tot hun wijze van recrutering en tenslotte op de collegevorming in Limburgse gemeenten.

In dit afsluitende hoofdstuk kijken wij terug op de resultaten van het onderzoek naar ontwikkelingen in de Limburgse lokale politiek.

\section{Maatschappelijke ontwikkelingen in Limburg}

De staatkundige geschiedenis en de sociaal-economische, sociaal-geografische en culturele ontwikkelingen in de provincie Limburg indiceren met betrekking tot een aantal aspecten een aparte positie van deze provincie, in vergelijking met de overige provincies van ons land. Wat dit betreft kan onder andere gewezen worden op het betrekkelijk late tijdstip waarop dit gebied haar definitieve karakter als Nederlandse provincie verkreeg, de culturele invloeden vanuit het omringende buitenland, het katholieke karakter en de sterk van het Nederlands afwijkende streektalen.

Deze afwijkende positie komt eveneens naar voren als wij de electorale ontwikkelingen bij boven-lokale verkiezingen in ogenschouw nemen. Limburgse kiezers stemden tot in de jaren zestig heel massaal op de KVP. In de betrekkelijke korte periode van 1963 tot 1972 daalde de aanhang van de katholieke partij echter van bijna tachtig naar ruim veertig procent van de kiezers. De opvolger van deze partij, het CDA, blijft tot het eind van de onderzoeksperiode de partij met de meeste aanhang in Limburg. Bijna de helft van de kiezers stemde op de christen-democraten, aanmerkelijk meer dan het landelijk gemiddelde (rond een derde). Als tweede partij kwam, vooral vanaf 
1977, de PVDA sterk op in Limburg. In de jaren tachtig verkreeg deze partij ongeveer een derde van het electoraat achter zich. Aan het eind van de onderzoeksperiode was er sprake van een scherpe daling van de aanhang van deze partij. De overige landelijke partijen verwierven slechts een beperkte en instabiele electorale positie in deze provincie.

\section{Electorale ontwikkelingen in de Limburgse lokale politiek}

Deze ingrijpende electorale wijzigingen kregen pas veel later gevolgen voor de meeste lokale politieke systemen. Tot aan de gemeenteraadsverkiezingen van 1978 is namelijk nauwelijks sprake geweest van deelname van de landelijke lijsten aan de lokale politiek in deze provincie. Buiten enkele grotere steden deden vrijwel uitsluitend lokale lijsten aan verkiezingen mee. De niet-confessionele partijen waren over het algemeen op het platteland niet sterk genoeg om met succesvolle eigen lijsten uit te komen. De afwezigheid van de KVP verklaren wij met name vanuit de afwerende houding van plaatselijke politieke leiders en de angst voor dissidentisme van het KVP-kader.

Vanaf 1978 en met name bij de verkiezingen van 1992, (in het herindelingsgebied Zuid-Limburg eind 1981), werden er in steeds meer gemeenten landelijke lijsten geïntroduceerd. Aanvankelijk breidden met name de PvdA en de VVD, die bij boven-lokale verkiezingen in Limburg toenemende aanhang verwierven, hun deelname uit. Later nam het CDA, als opvolger van de KVP, in veel gemeenten het initiatief. Het resultaat was dat aan het eind van de onderzoeksperiode het CDA en de PvdA in vrijwel alle Limburgse gemeenten met een eigen lijst uitkwamen. De VVD bleef wat dat betreft enigszins achter. Overige landelijke partijen waren buiten de grotere steden nog steeds zelden vertegenwoordigd.

De landelijke lijsten, met name het CDA, slaagden er vaak in om bestalande lokale lijsten en gevestigde politieke leiders in hun gelederen op te nemen. Bij de lokale lijsten was sprake van een sterke sanering: veel kleine lijsten hieven zich op en slechts een beperkt aantal grotere bleef als zelfstandige lijst voortbestaan.

Ten gevolge van deze deelname van landelijke lijsten zijn de politieke verhoudingen in de meeste gemeenten sterk veranderd. In tweederde van de Limburgse gemeenten verwierven de landelijke lijsten samen in 1990 een meerderheid in de raad. In eveneens ongeveer tweederde van de gemeenteraden vormde het CDA in dat jaar de grootste fractie. Toch bleven de lokale lijsten een aanzienlijke kiezersaanhang behouden. In de periode 1990-1994 beschikten deze lijsten gezamenlijk over bijna 40 procent van de Limburgse raadszetels. De Limburgse lokale politiek was in betrekkelijk korte tijd in sterke mate genationaliseerd, maar lokale lijsten bleven in veel gemeenten een belangrijke rol spelen. 


\section{Aard en functioneren van lokale lijsten}

Nadat is vastgesteld dat lokale lijsten een belangrijke rol hebben gespeeld en spelen in de Limburgse lokale politiek, komt de vraag op waar deze lijsten voor staan, welke motieven voor deelname zij hebben, hoe zij zijn georganiseerd en op welke manier zij functioneren.

Lokale lijsten kunnen in verband worden gebracht met vier typen scheidslijnen; territoriale (dorpen, buurten, wijken), sociaal-economische (beroepsgroepen, stiunden, klassen), 'culturele' (met name verenigingen) en persoonsgebonden scheidslijnen. Naast deze traditionele scheidslijn in de Limburgse lokale politiek komen er in de jaren zeventig ook vemieuwingsgezinde lokale lijsten naar voren, die zich afzetten tegen de bestaande lijsten en politieke leiders en zich veelal profileren aan de hand van een standpunt in een concrete beleidskwestie.

Toepassing van deze typologie van lokale lijsten levert problemen op aangezien allerlei mengvormen voorkomen, namen van lijsten weinig houvast bieden en vaak sprake is van verschuiving van het profiel in de tijd. Alleen door het verrichten van longitudinale case-studies kan een betrouwbaar beeld worden verkregen van de achtergrond van de verschillende lokale lijsten in een bepaalde gemeente.

Aan de hand van enkele case-studies, alsmede de resultaten van een in 1986 uitgevoerde mondelinge enquête onder lijsttrekkers van lokale lijsten bij de verkiezingen van 1982 in vijftien Limburgse gemeenten, komen wij tot de voorzichtige conclusie dat de culturele en sociaal-economische scheidslijn in de jaren tachtig een geringe rol speelden.

Een ander resultaat van de lijsttrekkersenquête betreft de politieke voorkeur van lijsttrekkers van lokale lijsten bij boven-lokale verkiezingen. Deze voorkeur bleek tamelijk heterogeen te zijn. De in politiek-ideologisch opzicht heterogene samenstelling van de lijst werd bovendien door verschillende lijsttrekkers onderstreept. Dit gegeven, gevoegd bij het feit dat de meeste van deze lijsten vanaf de jaren tachtig in een concurrentie-verhouding met het CDA verkeerden, leidt tot de conclusie dat de lokale lijsten in Limburg in ieder geval niet als verkapte confessionele lijsten kunnen worden beschouwd.

Uit de op de jaren tachtig betrekking hebbende lijsttrekkersenquête blijkt voorts dat er qua organisatiestructuur een groot verschil bestond tussen landelijke lijsten en de meeste lokale lijsten. Plaatselijke afdelingen van landelijke partijen waren gericht op continuiteit, poogden het ledental te verhogen en waren georganiseerd volgens landelijke statuten, hetgeen onder andere een van de fractie onafhankelijk bestuur, dat gecontroleerd wordt door de ledenvergadering impliceert.

De meeste lokale politieke groeperingen, daarentegen, vormden een betrekkelijke losse, informele organisatie, zonder de mogelijkheid te bieden aan kiezers om lid te worden of met slechts een beperkt aantal leden. Institutionalisering als een op continuïteit gerichte politieke vereniging bleef veelal achterwege.

Dit heeft ook gevolgen voor het functioneren van lokale lijsten. In deze studie zijn de wijze van kandidaatstelling en het opstellen van verkiezingsprogramma's bij de verkiezingen van 1982 onderzocht. De kandidaatstelling bij landelijke lijsten vond op 
een in de statuten geregelde wijze plaats, waarbij gewooniijk het bestuur als voorbereider en de ledenvergadering als besluitvormend orgaan optraden. Bij lokale lijsten werd de lijstvolgorde van kandidaten in de regel in onderlinge overeenstemming door de kandidaten zelf overeen gekomen. Vervolgens werd aan de persoonlijke voorkeurstem van de kiezers een zwaarder gewicht toegekend dan volgt uit de regeling van de Kieswet, inzake het bij voorkeur verkozen worden. De aan deze groeperingen toegewezen zetels werden bijna steeds ingenomen door de personen met het grootste absolute aantal voorkeursstemmen, waarbij een enkele stem de doorslag kon geven. De lijstvolgorde heeft in dat geval een betrekkelijker waarde dan wanneer de Kieswet zou worden gevolgd. Lokale lijsten bleken tenslotte aanmerkelijk minder uitgebreide verkiezingsprogramma's op te stellen dan landelijke lijsten.

Aan het eind van de onderzoeksperiode lijken de verschillen tussen lokale en landelijke lijsten zoals die uit de lijsttrekkersenquête naar voren komen, af te nemen. Het opheffen van veel kleine lijsten en de professionalisering van overblijvende grotere lokale lijsten heeft tot gevolg, dat veel plaatselijke politieke groeperingen qua organisatie en functioneren meer zijn gaan lijken op afdelingen van landelijk partijen.

\section{De band tussen kiezers en politici}

Een analyse van het aantal uitgebrachte voorkeurstemmen, de resultaten van enkele kiezersonderzoeken en de gegevens die met behulp van de lijsttrekkersenquête zijn vermeld, wijzen op een sterk persoonlijke band tussen kiezers en gekozenen in de Limburgse lokale politiek. Vooral kiezers die hun stem uitbrachten op lokale lijsten en het CDA bleken primair op een persoon te stemmen en in mindere mate op een partij of programma. Bij de overige landelijke partijen was dat in mindere mate het geval.

Daarnaast klonk vaak een instrumenteel element in de band tussen burgers en politici, waarbij sprake was van persoonlijke dienstverlening, een verschijnsel dat met de term cliëntelisme kan worden aangeduid.

Het is niet direkt te verwachten dat de band tussen kiezers en politici sterk zal veranderen door de introduktie van landelijke partijen. De komst van dit soort partijen opende juist nieuwe mogelijkheden voor nog effectievere vormen.van dienstverlening door lokale politici, gegeven de dwarsbanden met provinciale, nationale en Europese niveaus. Gelet op de bestaande politieke cultuur op dit punt achten wij het waarschijnlijk dat plaatselijke politici ook in de toekomst van deze mogelijkheden gebruik zullen maken om cliëntelistische betrekkingen met de kiezers te onderhouden.

\section{Recrutering en kenmerken van politieke leiders}

In het verlengde van de organisatie en het functioneren van de verschillende typen lijsten, alsmede de aard van de band tussen kiezers en gekozen in Limburg, is 
onderzocht wat de kenmerken van plaatselijke politieke leiders zijn en welke factoren een belangrijke rol hebben gespeeld bij hun recruteringsproces.

Aan de hand van de resultaten van de mondelinge lijsttrekkersenquête hebben wij een profiel opgesteld van de gemiddelde lijsttrekker in de Limburgse lokale politiek in de jaren tachtig.

Voor de lokale lijsten was de typische lijsttrekker een man van in de vijftig, die zijn hele leven in de betreffende gemeente had gewoond, actief lid was van verenigingen en de kerk, een tamelijk laag opleidingsniveau had genoten en werkzaam was in de private sector. De gemiddelde CDA-lijsttrekker sloot goed aan bij dit profiel, zij het dat er gemiddeld sprake was van een hoger opleidingsniveau, terwijl het activisme in de kerk, verenigingen en ook instellingen en organen (bijvoorbeeld woningbouwcorporaties) nog iets groter was. Voor deze respondenten gold overigens dat een groot aantal van hen aanvankelijk via een lokale lijst in de lokale politiek was terecht gekomen.

De lijsttrekkers van andere landelijke partijen weken op een aantal punten nogal af van dit profiel. Zij waren over het algemeen jonger, hoger opgeleid, woonden korter in de betreffende gemeente, waren minder kerkelijk en ook minder actief in het gemeenschapsleven. Lijsttrekkers van linkse partijen waren over het algemeen werkzaam in de publieke sector.

Dat deze verschillen samenhingen met de aard van het recruteringskader van respectievelijk lokale lijsten en plaatselijke afdelingen van een landelijke partij, bleek ook uit het feit dat volgens lijsttrekkers van landelijke partijen het functioneren binnen de eigen afdeling van zeer groot belang werd geacht bij de eerste kandidaatstelling. Deze factor werd door geen van de respondenten van lokale lijsten genoemd. Het zwaarste gewicht werd door deze lijsttrekkers toegekend aan de activiteiten in het verenigingsleven. Dat gold ook voor de CDA-respondenten, die vrijwel allemaal ten tijde van hun eerste kandidaatstelling nog lid waren van een lokale lijst.

De formalisering van recruteringsprocessen via politieke partijen, heeft gevolgen voor het profiel van de politieke leiders. Aan de ene kant kunnen politieke partijen, door gerichte aandacht, zorgen voor een vergroting van kansen van groepen die bij informele selectie een hoge drempel ondervinden, zoals vrouwen, jongeren en allochtonen. Aan de andere kant heeft partijactivisme een tamelijk elitair karakter zodat het waarschijnlijk is dat de politieke leiders die via politieke partijen worden gerecruteerd, qua opleiding en sociaal-economische status in mindere mate aansluiten bij de doorsnee van de bevolking.

\section{Collegevorming in Limburgse gemeenten}

Voor de communalistische periode, waarin de lokale politiek vrijwel geheel gedragen werd door lokale lijsten, geeft de collegevorming een beeld te zien van tamelijk sterke polarisatie, blijkend uit de veelal krappe meerderheden waarmee wethouders werden verkozen. De op de jaren tachtig betrekking hebbende lijsttrekkersenquête geeft geen duidelijke bevestiging van dit beeld. De aard van de relaties tussen de diverse actoren 
binnen het gemeentebestuur werden door de meeste respondenten gemiddeld genomen met 'geven en nemen' aangeduid. Binnen colleges van B en W kwam regelmatig eensgezindheid voor. Wel viel de gemeenteraad bij belangrijke stemmingen in tweederde van de steekproefgemeenten in twee blokken uiteen.

De meeste respondenten van de lijsttrekkersenquête spraken een voorkeur uit voor colleges die op brede basis in de raad rustten. Ruim tweederde van de in Limburg in de periode 1982-1990 gevoimde colleges voldeden aan de afspiegelingsnorm. Toch kwam slechts in 35 procent van de gemeenten in alle drie verkiezingsjaren in deze periode een afspiegelingscollege tot stand. De afspiegelingsnorm was kennelijk in veel gemeenten (nog) niet sterk geworteld. Bij de vorming van niet-afspiegelingscolleges bleek in de meeste gevallen enige polarisatie tussen het CDA en de grote lokale lijsten in de betreffende gemeente een rol te spelen.

Niettemin concluderen wij dat de nationalisering van de lokale politiek ertoe heeft geleid dat de steun voor colleges over het algemeen breder is geworden.

\section{Conclusie}

Afsluitend stellen wij vast dat zich vooral de afgelopen vijftien jaar diepgaande veranderingen in de Limburgse lokale politiek hebben voltrokken. De lokale lijsten hebben veel terrein verloren aan landelijke lijsten, maar aan het eind van de onderzoeksperiode was er in veel gemeente sprake van een stabilisatie van hun electorale positie. Het aantal lijsten is sterk verminderd en er is een professionaliseringtendens zichtbaar, hetgeen gevolgen zal hebben voor de aard van de recrutering en daammee de kenmerken van politici. Deze ontwikkelingen zullen echter niet noodzakelijkerwijs een einde maken aan de veelal persoonsgeoriënteerde en cliëntelistisch getinte bindingen tussen kiezers en gekozenen in Limburg. De mate van polarisering binnen het lokaal bestuur, tenslotte, lijkt enigszins te zijn afgenomen. 


\section{Appendix I}

\section{STEEKPROEFTREKKING LIJSTTREKKERSENQUETE}

Bij de lijsttrekkersenquête kunnen de volgende twee analyse-eenheden onderscheiden worden:

- lokale en nationale lijsten c.q. lijsttrekkers daarvan die deelnamen aan de gemeenteraadsverkiezingen van 1982 in deze provincie;

- gemeenten van de provincie Limburg;

Om te bereiken dat de betreffende analyse-eenheden in de steekproef op enkele relevant geachte factoren gelijkenis zouden vertonen met de gehele populatie, is gekozen om een steekproef te trekken uit gemeenten, gestratificeerd naar het percentage zetels in de raad dat door kandidaten van lokale lijsten in 1982 werd behaald. De Limburgse gemeenten werden op grond van dit criterium in de volgende vier categorieën onderverdeeld:

Groep A: gemeenten waarin minder dan 25 procent der zetels in de raad na de verkiezingen van 1982 werd ingenomen door kandidaten van lokale lijsten;

Groep B: gemeenten waarin tussen 25 en 50 procent der zetels in de raad na de verkiezingen van 1982 werd ingenomen door kandidaten van lokale lijsten;

Groep C: gemeenten waarin tussen 50 en 100 procent der zetels in de raad na de verkiezingen van 1982 werd ingenomen door kandidaten van lokale lijsten

Groep D: gemeenten waarin 100 procent der zetels in de raad na de verkiezingen van 1982 werd ingenomen door kandidaten van lokale lijsten.

Het steekproefpercentage werd gesteld op circa 20 procent, waarbij in de minst omvangrijke groep A naar boven werd afgerond en in de overige groepen naar beneden. Dit levert het overzicht van tabel I.1 op.

Per groep werden de gezochte gemeenten random getrokken (met behulp van de SPSSX-procedure SAMPLE).

De op deze wijze geselecteerde gemeenten zijn:

Groep A: Maastricht en Roermond;

Groep B: Brunssum, Eijsden, Helden en Landgraaf;

Groep C: Arcen en Velden, Beesel, Broekhuizen, Echt, Margraten en Nuth;

Groep D: Stevensweert, Stramproy en Thom.

Als het steekproefresultaat op het niveau van de gemeente wordt bekeken naar de factoren inwonertal, de urbanisatiegraad en geografische spreiding binnen de provin- 
cie, dan blijkt de verdeling van gemeenten in de steekproef redelijk tot goed overeen te komen met de populatie.

Door alle lijsttrekkers in de onderzoeksgemeenten bij de enquête te betrekken, werd beoogd om ook op het niveau van de lijsten c.q. lijsttrekkers een op de populatie gelijkende steekproef te verkrijgen.

In tabel I. 2 is het verschil tussen de populatie en de steekproef te zien op de voor dit onderzoek centrale factor van de 'politieke kleur' van de respondenten, of wel het type lijst waartoe zij behoorden. Uit deze vergelijking blijkt dat respondenten van landelijke lijsten enigszins oververtegenwoordigd zijn in de steekproef, hetgeen met name veroorzaakt wordt door het relatief grote aantal lijsttrekkers van de VVD en van kleinere linkse partijen. Evenals bij het aantal bij het onderzoek betrokken gemeenten, geldt dat het steekproefpercentage van de lokale en landelijke lijsten rond de 20 procent ligt (respectievelijk 18 procent en 23 procent).

Tabel I.1. Gemeenten naar het bij gemeenteraadsverkiezingen van 1982 in de respectievelijke gemeenteraden door lokale lijsten behaalde zetelpercentage, in de populatie en in de steekproef.

\begin{tabular}{lll}
\hline & \multicolumn{2}{c}{ Aantal gemeenten } \\
\cline { 2 - 3 } & populatie & steekproef \\
\hline Groep A & 8 & 2 \\
Groep B & 21 & 4 \\
Groep C & 27 & 6 \\
Groep D & 13 & 3 \\
Totaal & 69 & 15 \\
\hline
\end{tabular}

Tabel I.2. Verdeling van lijsten c.q. lijsttrekkers over verschillende typen lijsten in de populatie en in de steekproef.

\begin{tabular}{lcc}
\hline & \multicolumn{2}{c}{ Percentage lijsten/lijsttrekkers } \\
\cline { 2 - 3 } & populatie & steekproef \\
\hline CDA & $11,6 \%$ & $10,2 \%$ \\
PvdA & $8,7 \%$ & $9,2 \%$ \\
VVD & $8,1 \%$ & $11,2 \%$ \\
Klein Links & $9,8 \%$ & $13,3 \%$ \\
Totaal landelijke lijsten & $38,2 \%$ & $43,9 \%$ \\
Lokale lijsten & $61,8 \%$ & $56,1 \%$ \\
& $100 \%$ & $100 \%$ \\
Totaal & $(482)$ & $(98)$ \\
\hline
\end{tabular}




\section{Appendix II}

\section{TABELLEN BLJ HOOFDSTUK 5}

In tabel II. I. zijn de antwoorden op de volgende vraag weergegeven; "In welke mate dragen volgens u deze (onderstaande) campagne-activiteiten bij tot succes van uw lijst bij raadsverkiezingen?"

Tabel U.1. Mate waarin campagne-activiteiten volgens lijsttrekkers bijdragen aan het eigen succes, naar type lijst.

\begin{tabular}{|c|c|c|c|c|}
\hline Folders verspreiden & $\begin{array}{l}\text { Lokale } \\
\text { lijsten }\end{array}$ & $\mathrm{CDA}$ & $\begin{array}{l}\text { Ov. landel. } \\
\text { lijsten }\end{array}$ & Totaal \\
\hline veel & 12 & 3 & - & $\begin{array}{l}15 \\
(26 \%)\end{array}$ \\
\hline matig & 15 & 5 & 16 & $\begin{array}{l}36 \\
(62 \%)\end{array}$ \\
\hline niet & 4 & 1 & 2 & $\begin{array}{l}7 \\
(12 \%)\end{array}$ \\
\hline Totaal & 31 & 9 & 18 & $\begin{array}{l}58 \\
(100 \%)\end{array}$ \\
\hline \multicolumn{5}{|l|}{$c h i^{2}=13,29 ;(p \leq 0,01)$} \\
\hline Advertenties & $\begin{array}{l}\text { Lokale } \\
\text { lijsten }\end{array}$ & $\mathrm{CDA}$ & $\begin{array}{l}\text { Ov. landel. } \\
\text { lijsten }\end{array}$ & Tocaal \\
\hline veel & 4 & 3 & - & $\begin{array}{l}7 \\
(13 \%)\end{array}$ \\
\hline matig & 12 & 5 & 16 & $\begin{array}{l}33 \\
(60 \%)\end{array}$ \\
\hline niet & 12 & 1 & 2 & $\begin{array}{l}15 \\
(27 \%)\end{array}$ \\
\hline Totaal & 28 & 9 & 18 & $\begin{array}{l}55 \\
(100 \%)\end{array}$ \\
\hline geen antwoord & 3 & - & - & 3 \\
\hline$c h i^{2}=14,71 ;(p \leq 0,005)$ & & & & \\
\hline
\end{tabular}




\begin{tabular}{|c|c|c|c|c|}
\hline Posters ophangen & $\begin{array}{l}\text { Lokale } \\
\text { lijsten }\end{array}$ & CDA & $\begin{array}{l}\text { Ov. landel. } \\
\text { lijsten }\end{array}$ & Totaal \\
\hline veel & 6 & 3 & 2 & $\begin{array}{l}11 \\
(20 \%)\end{array}$ \\
\hline matig & 14 & 5 & 14 & $\begin{array}{l}33 \\
(58 \%)\end{array}$ \\
\hline niet & 9 & 1 & 2 & $\begin{array}{l}12 \\
(22 \%)\end{array}$ \\
\hline Totaal & 29 & 9 & 18 & $\begin{array}{l}56 \\
(100 \%)\end{array}$ \\
\hline geen antwoord & 2 & 一 & 一 & 2 \\
\hline \multicolumn{5}{|l|}{$\mathrm{chi}^{2}=6,11 ;$ (niet-sign.) } \\
\hline Toespraken, forumdiscussies & $\begin{array}{l}\text { Lokale } \\
\text { lijsten }\end{array}$ & CDA & $\begin{array}{l}\text { Ov. landel. } \\
\text { lijsten }\end{array}$ & Totaal \\
\hline veel & 6 & 1 & 4 & $\begin{array}{l}11 \\
(19 \%)\end{array}$ \\
\hline matig & 7 & 2 & 10 & $\begin{array}{l}19 \\
(33 \%)\end{array}$ \\
\hline niet & 18 & 6 & 4 & $\begin{array}{l}28 \\
(48 \%)\end{array}$ \\
\hline Totaal & 31 & 9 & 18 & $\begin{array}{l}58 \\
(100 \%)\end{array}$ \\
\hline \multicolumn{5}{|l|}{ chi $^{2}=8,33 ;$ (niet-sign.) } \\
\hline \multicolumn{5}{|c|}{ Zoveel mogelijk contact met burgers in openbare gelegenheden, bij feesten, etc. } \\
\hline & $\begin{array}{l}\text { Lokale } \\
\text { lijsten }\end{array}$ & & $\begin{array}{l}\text { Ov. landel. } \\
\text { lijsten }\end{array}$ & Totaal \\
\hline veel & 21 & 6 & 3 & $\begin{array}{l}30 \\
(52 \%)\end{array}$ \\
\hline matig & 2 & - & 9 & $\begin{array}{l}11 \\
(19 \%)\end{array}$ \\
\hline niet & 8 & 3 & 6 & $\begin{array}{l}17 \\
(29 \%)\end{array}$ \\
\hline Totaal & 31 & 9 & 18 & $\begin{array}{l}58 \\
(100 \%)\end{array}$ \\
\hline$c h i^{2}=19,97 ;(p \leq 0,005)$ & & & & \\
\hline
\end{tabular}




\begin{tabular}{|c|c|c|c|c|}
\hline Andere publiciteit (krant/radio) & $\begin{array}{l}\text { Lokale } \\
\text { lijsten }\end{array}$ & CDA & $\begin{array}{l}\text { Ov. landel. } \\
\text { lijsten }\end{array}$ & Totaal \\
\hline veel & 1 & 2 & 5 & $\begin{array}{l}8 \\
(14 \%)\end{array}$ \\
\hline matig & 6 & 3 & 8 & $\begin{array}{l}17 \\
(30 \%)\end{array}$ \\
\hline niet & 22 & 4 & 5 & $\begin{array}{l}31 \\
(56 \%)\end{array}$ \\
\hline Totaal & 29 & 9 & 18 & $\begin{array}{l}56 \\
(100 \%)\end{array}$ \\
\hline geen antwoord & 2 & - & - & 2 \\
\hline \multicolumn{5}{|l|}{$c h i^{2}=11,86 ;(p \leq 0,01)$} \\
\hline Huisbezoeken ('canvassing') & $\begin{array}{l}\text { Lokale } \\
\text { lijsten }\end{array}$ & $\mathrm{CDA}$ & $\begin{array}{l}\text { Ov. landel. } \\
\text { lijsten }\end{array}$ & Totaal \\
\hline veel & 15 & 6 & 4 & $\begin{array}{l}25 \\
(43 \%)\end{array}$ \\
\hline matig & 1 & - & 7 & $\begin{array}{l}8 \\
(14 \%)\end{array}$ \\
\hline niet & 15 & 3 & 7 & $\begin{array}{l}25 \\
(43 \%)\end{array}$ \\
\hline Totaal & 31 & 9 & 18 & $\begin{array}{l}58 \\
(100 \%)\end{array}$ \\
\hline $\mathrm{chi}^{2}=15,48 ;(p \leq 0,005)$ & & & & \\
\hline
\end{tabular}

Bron: Lijsttrekkersenquête, RL.

In tabel II.2. is de respons op de volgende vraag weergegeven: "Bij de keuze van de kiezers voor uw lijst in 1982 zullen verschillende zaken een rol hebben gespeeld. Kunt u aangeven hoe belangrijk naar uw mening de hieronder genoemde zaken waren?"

De volgende zaken werden aan de respondent voorgelegd:

- de inzet voor individuele kiezers door open te staan voor en te helpen bij hun persoonlijke problemen;

- de persoonlijke inzet in de plaatselijke gemeenschap;

- de standpunten van de lijsttrekkers en diens groepering bij bepaalde beleidskwesties;

- de afkomst uit een bepaald dorp of stadsdeel;

- het verkiezingsprogramma van de groepering;

- ontwikkelingen in de landelijke politiek.

(Kortheidshalve is de categorie niet of nauwelijks belangrijk aangeduid als 'niet belangrijk'.) 
Tabel II.2. Oordeel van de lijsttrekkers over het belang van diverse factoren bij de keuze van de eigen kiezers, naar type lijst*.

\begin{tabular}{|c|c|c|c|c|}
\hline Inzet voor individuele kiezers & $\begin{array}{l}\text { Lokale } \\
\text { lijsten }\end{array}$ & $\mathrm{CDA}$ & $\begin{array}{l}\text { Ov. landel. } \\
\text { lijsten }\end{array}$ & Totaal \\
\hline $\begin{array}{l}\text { heel } \\
\text { belangrijk }\end{array}$ & 24 & 9 & 7 & $\begin{array}{l}40 \\
(69 \%)\end{array}$ \\
\hline $\begin{array}{l}\text { enigszins } \\
\text { belangrijk }\end{array}$ & 6 & - & 7 & $\begin{array}{l}13 \\
(22 \%)\end{array}$ \\
\hline $\begin{array}{l}\text { niet } \\
\text { belangrijk }\end{array}$ & 1 & - & 4 & $\begin{array}{l}5 \\
(9 \%)\end{array}$ \\
\hline Totaal & 31. & 9 & 18 & $\begin{array}{l}58 \\
(1100 \%)\end{array}$ \\
\hline \multicolumn{5}{|l|}{$\operatorname{chi}^{2}=12,64 ;(p \leq 0,005)$} \\
\hline Inzet in de plaatselijke gemeenschap & $\begin{array}{l}\text { Lokale } \\
\text { lijsten }\end{array}$ & CDA & $\begin{array}{l}\text { Ov. landel. } \\
\text { lijsten }\end{array}$ & Totaal \\
\hline $\begin{array}{l}\text { hee! } \\
\text { belangrijk }\end{array}$ & 27 & 6 & 8 & $\begin{array}{l}41 \\
(72 \%)\end{array}$ \\
\hline $\begin{array}{l}\text { enigszins } \\
\text { belangrijk: }\end{array}$ & 3 & 3 & 7 & $\begin{array}{l}13 \\
(23 \%)\end{array}$ \\
\hline $\begin{array}{l}\text { niet } \\
\text { belangrijk }\end{array}$ & 1 & - & 2 & $\begin{array}{l}3 \\
(5 \%)\end{array}$ \\
\hline Totaal & 31 & 9 & 17 & $\begin{array}{l}57 \\
(100 \%)\end{array}$ \\
\hline geen antwoord & - & - & 1 & 1 \\
\hline
\end{tabular}

Standpunten over bepaalde beleidskwesties

\begin{tabular}{|c|c|c|c|c|}
\hline & $\begin{array}{l}\text { Lokale } \\
\text { lijsten }\end{array}$ & CDA & $\begin{array}{l}\text { Ov. landel. } \\
\text { lijsten }\end{array}$ & Totaal \\
\hline $\begin{array}{l}\text { heel } \\
\text { belangrijk }\end{array}$ & 23 & 4 & 14 & $\begin{array}{l}41 \\
(71 \%)\end{array}$ \\
\hline $\begin{array}{l}\text { enigszins } \\
\text { belangrijk }\end{array}$ & 7 & 5 & 4 & $\begin{array}{l}16 \\
(27 \%)\end{array}$ \\
\hline $\begin{array}{l}\text { niet } \\
\text { belangrijk }\end{array}$ & 1 & - & - & $\begin{array}{l}1 \\
(2 \%)\end{array}$ \\
\hline Totaal & 31 & 9) & 18 & $\begin{array}{l}58 \\
(100 \%)\end{array}$ \\
\hline
\end{tabular}

$\mathrm{chi}^{2}=4,13 ;$ (niet-sign.) 
Afkomst uit een bepaald dorp of stadsdeel

\begin{tabular}{|c|c|c|c|c|}
\hline  & $\begin{array}{l}\text { Lokale } \\
\text { lijsten }\end{array}$ & $\mathrm{CDA}$ & $\begin{array}{l}\text { Ov. landel. } \\
\text { lijsten }\end{array}$ & Totaal \\
\hline $\begin{array}{l}\text { heel } \\
\text { belangrijk }\end{array}$ & 11 & 4 & - & $\begin{array}{l}15 \\
(26 \%)\end{array}$ \\
\hline $\begin{array}{l}\text { enigszins } \\
\text { belangrijk }\end{array}$ & 8 & 2 & 4 & $\begin{array}{l}14 \\
(25 \%)\end{array}$ \\
\hline $\begin{array}{l}\text { niet } \\
\text { belangrijk }\end{array}$ & 12 & 3 & 13 & $\begin{array}{l}28 \\
(49 \%)\end{array}$ \\
\hline Totaal & 31 & 9 & 17 & $\begin{array}{l}57 \\
(100 \%)\end{array}$ \\
\hline $\begin{array}{l}c h i^{2}=10,38 ;(p \leq 0,05) \\
\text { geen antwoord }\end{array}$ & - & - & 1 & 1 \\
\hline Verkiezingsprogramma & $\begin{array}{l}\text { Lokale } \\
\text { lijsten }\end{array}$ & CDA & $\begin{array}{l}\text { Ov. landel. } \\
\text { lijsten }\end{array}$ & Totaal \\
\hline $\begin{array}{l}\text { heel } \\
\text { belangrijk }\end{array}$ & 14 & 2 & 3 & $\begin{array}{l}19 \\
(33 \%)\end{array}$ \\
\hline $\begin{array}{l}\text { enigszins } \\
\text { belangrijk }\end{array}$ & 12 & 5 & 9 & $\begin{array}{l}26 \\
(46 \%)\end{array}$ \\
\hline $\begin{array}{l}\text { niet } \\
\text { belangrijk }\end{array}$ & 5 & 2 & 5 & $\begin{array}{l}12 \\
(21 \%)\end{array}$ \\
\hline Totaal & 31 & 9 & 16 & $\begin{array}{l}57 \\
(100 \%)\end{array}$ \\
\hline geen antwoord & - & 一 & 2 & 2 \\
\hline chi $^{2}=5,35 ;$ (niet-sign.) & & & & \\
\hline
\end{tabular}

Ontwikkelingen in de landelijke politiek

\begin{tabular}{|c|c|c|c|c|}
\hline & $\begin{array}{l}\text { Lokale } \\
\text { lijsten }\end{array}$ & $\mathrm{CDA}$ & $\begin{array}{l}\text { Ov. landel. } \\
\text { lijsten }\end{array}$ & Totaal \\
\hline $\begin{array}{l}\text { heel } \\
\text { belangrijk }\end{array}$ & 1 & 1 & 14 & $\begin{array}{l}16 \\
(28 \%)\end{array}$ \\
\hline $\begin{array}{l}\text { enigszins } \\
\text { belangrijk }\end{array}$ & 6 & 5 & 2 & $\begin{array}{l}13 \\
(22 \%)\end{array}$ \\
\hline $\begin{array}{l}\text { niet } \\
\text { belangrijk }\end{array}$ & 24 & 3 & 2 & $\begin{array}{l}29 \\
(50 \%)\end{array}$ \\
\hline Totaal & 31 & 9 & 18 & $\begin{array}{l}58 \\
(100 \%)\end{array}$ \\
\hline
\end{tabular}

$\operatorname{chi}^{2}=40,02 ;(p \leq 0,005)$

* Bij de volgende drie factoren kwamen verwachte celfrequenties kleiner dan 1 voor. inzet voor individuele kiezers, inzet in de plaatselijke gemeenschap en standpunten over bepaalde beleidskwesties. In alle gevallen betrof het de antwoorden 'niet belangrijk'. Voor de berekening van chi' is het geringe aantal respondenten met de betreffende respons bij de categorie 'enigszins belangrijk' gevoegd.

Bron: Lijsttrekkersenquête, $R L$ 



\section{Appendix III}

\section{TABEL BIJ HOOFDSTUK 6}

In tabel App.6.1 is de respons weergegeven op de volgende vraag uit de schriftelijke lijsttrekkersenquête:

"Toen u zich, hetzij uit eigener beweging, hetzij door anderen gevraagd, voor het eerst kandidaat stelde bij raadsverkiezingen, hoe belangrijk waren toen voor u de volgende factoren?"

Onder deze vraag waren de in de tabel genoemde factoren opgesomd, waarbij men de drie antwoordcategorieën 'heel belangrijk', 'enigszins belangrijk' en 'niet of nauwelijks belangrijk' kon aankruisen. (In de tabel is de laatste categorie kortheidshalve aangeduid als 'niet belangrijk'.)

Tabel App.6.1. Mening van lijsttrekkers over de rol van een aantal factoren bij de eerste kandidaatstelling, naar type lijst.

\begin{tabular}{lcccc}
$\begin{array}{l}\text { Bekendheid met een of meer zittende raadsleden } \\
\text { Lokale } \\
\text { lijsten }\end{array}$ & CDA & $\begin{array}{l}\text { Ov. landel. } \\
\text { lijsten }\end{array}$ & Totaal \\
\hline $\begin{array}{l}\text { heel } \\
\text { belangrijk } \\
\text { enigszins } \\
\text { belangrijk } \\
\text { niet } \\
\text { belangrijk }\end{array}$ & 10 & 1 & 1 & $\begin{array}{l}12 \\
(21 \%)\end{array}$ \\
$\begin{array}{l}\text { Totaal } \\
\text { chi }{ }^{2}=13,53 ;(p \leq 0,01)\end{array}$ & 9 & - & 2 & $\begin{array}{l}11 \\
(19 \%)\end{array}$ \\
\hline
\end{tabular}


Activiteiten in het verenigingsleven en/of kerkgenootschappen

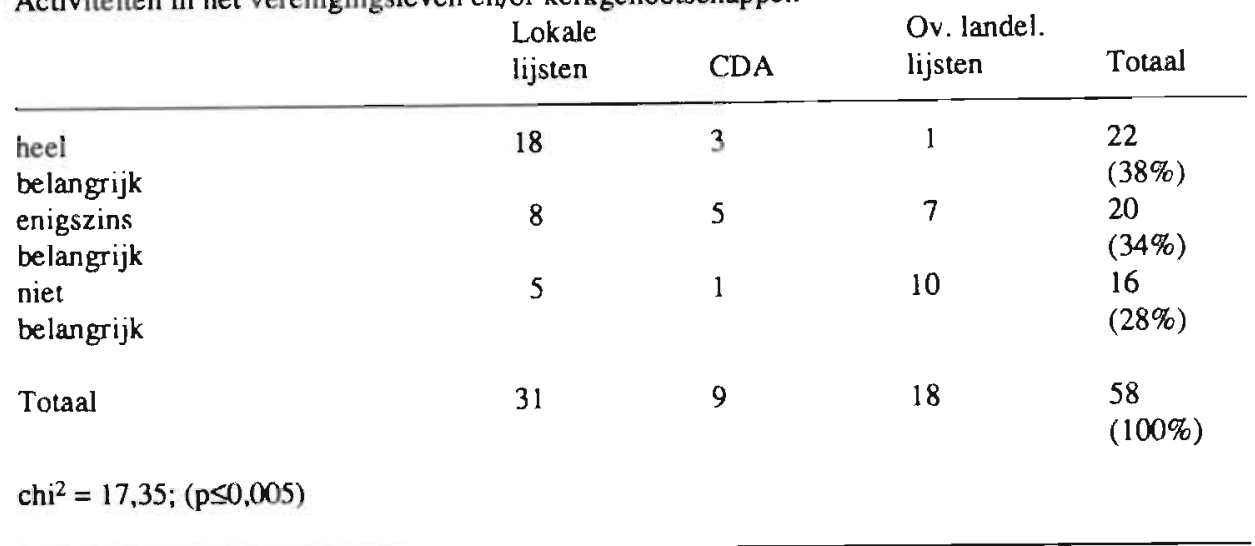

Activiteiten in bepaalde organen als schoolbesturen, woningbouwverenigingen, buurtcentra etc.




Het feit dat men in een bepaald dorp of stadsdeel woont

\begin{tabular}{lcccl} 
& $\begin{array}{l}\text { Lokale } \\
\text { lijsten }\end{array}$ & CDA & $\begin{array}{l}\text { Ov. landel. } \\
\text { lijsten }\end{array}$ & Totaal \\
\hline $\begin{array}{l}\text { heel } \\
\text { belangrijk } \\
\text { enigszins } \\
\text { belangrijk } \\
\text { niet }\end{array}$ & 12 & 2 & 2 & $\begin{array}{l}16 \\
(28 \%)\end{array}$ \\
belangrijk & 7 & 2 & 2 & $\begin{array}{l}11 \\
(19 \%)\end{array}$ \\
Totaal & 12 & 5 & 14 & $\begin{array}{l}31 \\
(53 \%)\end{array}$ \\
& 31 & 9 & 18 & $\begin{array}{l}58 \\
(100 \%)\end{array}$
\end{tabular}

chi $^{2}=7,42$; (niet sign.)

Het feit dat een of meer familieleden actief zijn (geweest) in de lokale politiek

\begin{tabular}{lcccc} 
& $\begin{array}{l}\text { Lokale } \\
\text { lijsten }\end{array}$ & CDA & $\begin{array}{l}\text { Ov. landel. } \\
\text { lijsten }\end{array}$ & Totaal \\
\hline $\begin{array}{l}\text { heel } \\
\text { belangrijk } \\
\text { enigszins } \\
\text { belangrijk } \\
\text { niet }\end{array}$ & 4 & - & - & 4 \\
belangrijk & 6 & 1 & - & $\begin{array}{l}7 \\
(7 \%)\end{array}$ \\
Totaal & 21 & 8 & 18 & $\begin{array}{l}47 \\
(81 \%)\end{array}$ \\
& 31 & 9 & 18 & $\begin{array}{l}58 \\
(100 \%)\end{array}$
\end{tabular}

$\mathrm{chi}^{2}=8,09$; (niet sign.)

Activiteiten binnen de organisatie van de eigen politieke groepering

\begin{tabular}{lcccl} 
& $\begin{array}{l}\text { Lokale } \\
\text { lijsten }\end{array}$ & CDA & $\begin{array}{l}\text { Ov. landel. } \\
\text { lijsten }\end{array}$ & Totaal \\
\hline $\begin{array}{l}\text { heel } \\
\text { belangrijk } \\
\text { enigszins } \\
\text { belangrijk } \\
\text { niet } \\
\text { belangrijk }\end{array}$ & 11 & 2 & 13 & 26 \\
$\begin{array}{l}\text { Totaal } \\
\text { chi }\end{array}$ & 8 & 2 & 4 & $\begin{array}{l}(45 \%) \\
14\end{array}$ \\
\hline
\end{tabular}

Bron: Lijsttrekkersenquête, RL 



\section{Summary}

A striking feature of local politics in the Dutch province of Limburg is the traditionally strong position of independent political groups. Until the 1970s, municipal elections in most municipalities were not contested by national parties. In the last two decades a remarkable process of nationalisation took place, leading to important changes in the structure and culture of local politics in Limburg. This monograph offers an exploration of local political systems dominated by independent or local lists, as well as the backgrounds and effects of this nationalisation process.

The analysis of political changes in Limburg municipalities cannot be isolated from an analysis of some other developments in the Limburg society at large. Chapter 2 therefore deals with the historic, social-economic and cultural context of local politics in this province. The peripheral position of Limburg within the Netherlands, in terms of both geography and culture, provides a natural background for different features of electoral behaviour at national and provincial elections. From 1946 to 1963 the Catholic People's Party (KVP) obtained about 80 percent of the vote in Limburg. This is explained by the existence of a catholic mono-culture in the southern part of the Netherlands, coupled with the pillarisation ('verzuiling') of Dutch society. Processes of secularisation and depolarisation became manifest in the $1960 \mathrm{~s}$. In the short period between 1963 and 1972 votes for the Catholic People's Party dropped to circa 40 percent. The Social-Democrat Labour Party (PvdA) established itself as the second largest party in Limburg, assembling approximately a third of the electorate in the eighties.

The third chapter focuses on the results of post-war municipal elections. The virtual absence of the KVP on the municipal level is explained by the fear of dissidentism and the lack of competition between the KVP and other national parties in this part of the country, as well as the hostile attitude of local political elites. The other national parties failed to gain enough membership and support to contest local elections. At the wake of the changes mentioned in electoral behaviour, however, their chances of success were growing in the seventies, resulting in a rapid expansion of their local branches and lists presented at municipal elections. This expansion in tum provoked a reaction of the Christian-Democrat Appeal (CDA), the successor-party of the KVP, formed at the end of the seventies. Making use of the possibilities offered by the enlargement of scale, due to municipal restructuring in 1982 and 1989, this party succeeded in setting up local branches in almost every municipality. Many former independents (individuals and groups) crossed over to the Christian-Democrats. The PvdA followed suit, whereas the other parties lagged far behind the Christian-Democrats and Social-Democrats, in their number of local branches. 
This process of penetration of national parties in the local arena radically changed the structure of most local political systems. National party-lists gained a majority of seats in two-thirds of the municipal councils. The CDA evolved as the strongest party group in almost 70 percent of the councils in Limburg. The independent groups retained only about 40 percent of the seats between 1990 and 1994, although in some municipalities they regained some of their lost territory. A massive regrouping of local lists took place in the eighties. As a result the traditional fragmentation of these lists diminished.

In chapter 4 we concentrate on these local lists or independent groups. Drawing on the results of a survey of independent leaders in fifteen municipalities, the profile, the organisation and the functioning of the conceming groups is compared with local branches of national parties. The survey gives an indication of the situation in the period between 1986 and 1990. In addition, the results of several longitudinal casestudies are used to reconstruct developments in greater detail.

Local lists are classified according to the social cleavages which they are linked to as territorial (representing villages or neighbourhoods), social-economic (representing professions or classes), cultural (representing voluntary associations) or personal lists. In the seventies a fifth category entered the local arena, comprising lists aiming at a renewal of the political structure and culture, and opposing the political establishment often focusing on specific policy issues. The social-economic and cultural cleavages seem to have lost political relevance in the post-war period. Classification of most of the lists under investigation, however, remained highly ambiguous.

Local branches of national parties and independent groups differ greatly in their organisation. The former are structured in conformity with national regulations, prescribing (among others) the possibility of membership and a separation of the council group and the board of the party-branch. Local lists in general are loosely organised groups, which come close to the type of political organisation Duverger dubbed caucuses. In coherence with these findings, the order of candidates on most local lists is decided on in an informal way, whereas within local branches of national parties this same decision is strictly guided by procedural regulations. Another marked difference exists between the two types of groups on a second basic function of political parties, the articulation of policy objectives.

Many local lists did not present a party manifesto and if they did, they amounted to one or two pages only. Lists of national parties provided on the contrary rather elaborate manifestos. In face of the increasing competition between national and local lists and the restructuring of the latter, a process of professionalisation of local lists is taking place, which tends to reduce the differences, highlighted in this chapter.

The consequences of the differing organisational outlook of national and local lists on the links between citizens and politicians are elaborated in chapter 5 . It is concluded that the links between the electorate and local politicians are characterised by rather strong personal and often clientelistic orientations. Clientelism is deeply rooted in the Limburg political culture; it has proved to be an effective way of securing votes and of accommodating the demands and pressures of citizens vis-a-vis the local political 
system. The introduction of national political parties on the local level even enhances more effective clientelistic activities based on intra-party links between local, regional and European level.

In chapter 6 we take a closer look at the characteristics of local political leaders and at the processes of candidate recruitment and selection. Using the findings of the survey mentioned earlier, two (ideal-)types of political leaders are distinguished. The first type of leaders is attached to the local lists and the CDA-lists. Leaders of these political parties are in their fifties, they are 'real locals' and they show a high level of activity in the community life. These activities played an important role during their recruitment as local politicians.

Leaders of the second type belong to lists of the other national parties. These leaders are comparatively young, well educated and less active in voluntary associations. In their case the level of party-activism constituted the most important factor leading to their own recruitment as candidates. Women are very rare among political leaders of all parties.

The differences between leaders of local lists and CDA-lists on the one hand and other national lists on the other hand, are expected to decrease as a result of the strengthening of the role of political parties (i.e. local branches of national parties or professionalised independent groups) as recruitment agencies.

Chapter 7 deals with local coalition formation in the province of Limburg. The executive of Dutch municipalities consists of an appointed burgomaster and two or more aldermen, who are elected by the municipal council. In most Dutch municipalities a tradition of accommodation has been established by applying the unwritten rule that aldermen are chosen proportionately ('afspiegeling'). As a consequence they are usually elected by large majorities.

This has not been the case in most Limburg municipalities during the period where national lists were not involved in the process of coalition formation. Consensus has been the exception rather than the rule. Most executives were supported by a small and in many cases unstable majority of council-members.

The nationalisation of local politics in Limburg changed this traditional pattem of coalition behaviour. By and large, coalitions formed in the period between 1982 and 1990, gained more support in the respective councils than in the previous period. Moreover, about two-thirds of the political leaders included in our survey showed a positive attitude towards the formation of 'grand coalitions' instead of coalitions supported by a small majority of council-members. Exceptions to the 'afspiegeling'rule were mostly due to a certain antagonism between the Christian-Democrats and the largest independent group represented in the council. In many other instances, however, this cleavage between the largest national and local lists did not emerge during the process of coalition formation. As a result, 'grand coalitions' between local and national lists were quite frequent during the last decade.

Finally, Chapter 8 summarises the findings of the previous chapters. 



\section{Literatuur}

Alberts, W.J., Geschiedenis van de beide Limburgen, deel II, Assen, 1974.

Andeweg, R.B., Dutch voters adrift, On explanations of electoral change (1963-1977), Leiden, 1982. Andeweg, R.B., A. Hoogerwerf en JJ.A. Thomassen (red.), Politiek in Nederland, Alphen a/d Rijn, 1985.

Andeweg, R.B. en R. Hillebrand, De kiezers en de PvdA, Veranderingen en mogelijkheden in het licht van een oud verkiezingsonderzoek, in: Bank, J. e.a. (red.), Het zesde jaarboek voor het democratisch socialisme, Amsterdam, 1985, p. 14-39.

Bailey, F.G., Strategems and spoils, A social anthropology of politics, Oxford, 1977.

Bakvis, H., Catholic power in the Netherlands, dissertatie, Kingston, 1978.

Bax, M., Harpstrings and confessions, Machine style politics in the Irish republic, Assen, 1976.

Bekkers, V., Gemeentelijke herindeling in en rondom Maasbracht, in: A.F.A. Korsten, W. Kuiper en F.P.C.L. Tonnaer (red.), Gemeentelijke herindeling, keuzen en kansen, Lessen uit Midden-Limburg, Zeist, 1991, p. 105-117.

Belloni, F., M. Caciagli en L. Mattina, The mass clientelism party: The Christian Democratic Party in Catania and in southern Italy, in: European Journal of Political Research, 1979 (7), p. 253.275.

Bense, M., De verantwoordingsplicht van het college van burgemeester en wethouders tegenover de gemeenteraad en ontslag van wethouder door de gemeenteraad, Amsterdam, 1983.

Boissevain, J., When the saints go marching out: Reflections on the decline of patronage in Malta, in: Gellner, E. en J. Waterbury (red.), Patrons and clients in mediterranean societies, London, 1977, p. 81-96.

Boogers, M. en R. Keizers, Een verdeelde eenheid, Lokale politiek in Sittard tussen 1900 en 1990 , Sint-Geertruid, 1991.

Bruce, A. en G. Lee, Local election campaigns, in: Political studies, 1983 (30), no. 2, p. 247-26 I.

Centraal Bureau voor de Statistiek, Statistiek der verkiezingen, gemeenteraadsverkiezingen, 's-Gravenhage, diverse jaargangen.

Centraal Bureau voor de Statistiek, Statistiek der verkiezingen, verkiezingen voor Ptovinciale Staten, 's-Gravenhage, diverse jaargangen.

Centraal Bureau voor de Statistiek. Statistiek der verkiezingen, verkiezingen voor de Tweede Kamer der Staten-Generaal, 's-Gravenhage, diverse jaargangen.

Centraal Bureau voor de Statistiek, 13e Algemene Volkstelling 1960, 's.Gravenhage, 1967.

Centraal Bureau voor de Statistiek, $14 \mathrm{e}$ Algemene Volkstelling 1971, 's-Gravenhage, 1982.

Centraal Bureau voor de Statistiek, Arbeidskrachtentelling 1981, 's-Gravenhage, 1985.

Centraal Bureau voor de Statistiek, Enquête beroepsbevolking 1991, 's-Gravenhage, 1992.

Chapman, J., Leaders and losers: A comparative study of competition, gender and the composition of local political leaderships in Scotland, the Soviet-Union and the U.S.A., Paper gepresenteerd tijdens de Joint Sessions of the ECPR, Amsterdam, 1987.

Chubb, J., Patronage, power and poverty in Southem Italy, Cambridge, 1977.

Cohen, M J. en K.L.L.M. Dittrich, De Limburgse gemeenteraadsverkiezingen, Het probleem van het stemmen bij volmacht, in: Nederlands Juristen Blad, 20 maart 1982, p. 347-351.

Costongs, J.E.L. en P.W. Tops (red.), Tilburg na 1945, Momenten van veranderingen in politiek, bestuur en beleid, Tilburg, 1986. 
Custers, J., Macht en meerderheid, Lokale politiek in Sint-Geertruid tussen 1919 en 1982, Sint-Geertruid/Maastricht, 1988.

Czudnowski, M.M., Political recruitment, in: Greenstein, F. en N. Polsby (red.), Handbook of political science, vol. 2, Reading, 1975, p. 155 e.v.

Daalder, H., Politisering en lijdelijkheid in de Nederlandse politiek, Assen, 1974.

Denters, B., Towards a conditional model of coalition-behaviour, in: European Journal of Political Research, 1985 (13), p. 295-3^9

Denters, B., Partijen, kiezers en gemeentelijk beleid, Een empirische toetsing van een politiek-economische theorie, Enschede, 1987.

Derks, W., Arbeidsmarkt, verstourd evenwicht, in: Soeters, J., H. Spoormans en R. Welten (red.), Het nieuwe Limburg, Herstructurering en ontwikkeling, Schiedam, 1990, p. 52-64.

Derksen, W., Macht in de gemeente, Amsterdam, 1985.

Derksen, W. en A.F.A. Korsten (red.), Lokaal bestuur in Nederland, Alphen a/d Rijn, 1985 en 1989 (tweede druk).

Dewachter, W., Het effect van de samenvoeging van gemeenten op de gemeenteraadsverkiezingen, in: Res Publica, 1986 (28), p. 235-260

Dittrich. K.L.L.M., Partij-politieke verhoudingen in Nederlandse gemeenten, een analyse van de gemeenteraadsverkiezingen 1962-1974, dissertatie, Leiden, 1978.

Dittrich, K.L.L.M., Limburg en de gemeentepolitiek, een analyse van de gemeenteraadsverkiezingen van 21 oktober 1981, in: Burg, F.H. van der en M.H. van der Ham (red.), Gemeentelijke vrijheden, Alphen a/d Rijn, 1983, p. 45-61.

Dittrich, K.L.L.M., P.W. Tops en R.G. Welten, Het gebeurde in het zuiden, in: Socialisme en Democratie, 1986 (43), p. 295-303.

Donneur, A.P. en J.G. Padiouleau, Local clientelism in post- industrial society, in: European Journal of Political Research 1982 (10), p. 71-82.

Downs, A., An Economic theory of democracy, New York, 1957.

Duffhues, T., A.J.A. Felling en J. Roes, Bewegende patronen, Een analyse van het landelijk netwerk van katholieke organisaties en bestuurders 1945-1980, Baam, 1985.

Duverger, M., Political parties: Their organization and activity in the modem state, derde editie, London, 1967.

Eijk, C. van der en B. Niemöller, Stemmen op godsdienstige partijen sinds 1967, in: Acta Politica, 1983 (18), p. 169-182.

Eisenstadt, S.N. en L. Roninger, Patrons, clients and friends, Cambridge, 1984.

Elias, N., Problemen van betrokkenheid en distantie, Amsterdam, 1982.

Elster, J., Ulysses and the sirens, Cambridge, 1979.

Engberg, J. en J. Gidlund, Organizations and pluralist democracy, in: Scandinavian Political Studies, 1982 (5), p. 315-335.

Eulau. H. en M.M. Czudnowski (red.), Elite recruitment in democratic polities, Indianapolis, 1976.

Eulau, H. en K. Prewitt, Labyrinths of democracy, Adaptations, linkages, representation and policies in urban politics, New York, 1973.

Felling, AJ.A. en J. Peters, Het culturpatroon van de katholieke en onkerkelijke Limburger in het midden van de jaren tachtig, in: Henau, E. en T. van den Hoogen (red.), Van katholiek Limburg naar katholieken in Limburg, Heerlen, 1988, p. 25-84.

Ferro b.v., Marktonderzoek, Peiling van de achtergronden van het verkiezingsresultaat in Zuid-Limburg ten dienste van de Partij van de Arbeid, Amsterdam, 1982.

Fockema Andreae, S., De Nederlandse staat onder de Republiek, Amsterdam, 1962 (tweede druk).

Gellner, E. en J. Waterbury (red.), Patrons and clients in mediterranean societies, London, 1977.

Girard, R., Des choses caches depuis les fondations du monde, Paris, 1978.

Grant, W., Independent local politics in England and Wales, Farnborough, 1977.

Graziano, L., Patron-client relationships in Southern Italy, in: European Journal of Political Research, 1973 (1), p. 3-34. 
Graziano, L., A conceptual framework for the study of clientelistic behavior, in: European Journal of Political Research, 1976 (4), p. 149-174.

Green, D.G., Power and party govemment in an English city, An account of single-party rule, London, 1981 .

Günes-Ayata, A., Factionalism and clientelism as strategies in leadership, Paper gepresenteerd tijdens de Joint Sessions of Workshops of the ECPR, Amsterdam, 1987.

Hamilton, C., The patron-recipient relationships and minority politics in New York, in: Political Science Quarterly, 1979 (94), p. 211-227.

Harrop, M. en W.L. Miller, Elections and voters, A comparative introduction, London, 1987.

Henau, E. en T. van den Hoogen (red.), Van katholiek Limburg naar katholieken in Limburg, Heerlen, 1988.

Hillebrand, R., De antichambre van het parlement, Kandidaatstelling in Nederlandse politieke partijen, dissertatie, Leiden, 1992.

Houska, J., Influencing mass political behavior, Elites and political subcultures in the Netherlands and Austria, Berkeley, 1985.

Hoogerwerf, A., Politicologie, Begrippen en problemen, Alphen a/d Rijn, 1978.

Huntington, S.P. en J.J. Dominguez, Political development, in: Greenstein, F.I. en N.W. Polsby (ed.), Handbook of political science, vol. 3, Reading, 1975, p. 1-114.

Instituut voor Toegepaste Sociologie, Achtergronden van stemgedrag. Een sociologisch onderzoek naar de achtergronden van het stemgedrag bij de verkiezingen voor de Provinciale Staten 1966 in de Limburgse Mijnstreek, Nijmegen, 1966.

Irwin, G.A., Party, accountability and the recruitment of Dutch municipal councilman, in: Eulau H. en M. Czudnowski (red.), Indianapolis, 1976.

Keers, C., H. Wilke en P.O. Kampschuur, Orièntatie in de sociale psychologie, Het individu en de groep, Alphen a/d Rijn, 1981 (vierde druk).

Kervel, A.DJ., Spelregels voor collegevorming, in: De Nederlandse Gerneente, 1982 (24), p. 365-367.

Knegt, R., Regels en redelijkheid in de bijstandsverlening, Groningen. 1987.

Knippenberg, E.T.C., Het gedwongen ontslag van wethouders in Limburgse gemeenten; artikel 87a Gemeentwet en de 'communalistische' politieke cultuur, Tijdschrifi voor Openbaar bestuur, 14-1-1988, p. 4-9.

Knippenberg, E.T.C. en A.F.A. Korsten, Vertegenwoordiging van vrouwen in Limburgse gemeentebesturen, in: Korsten, A.F.A. en W. Kuiper (red.), Limburg kiest, Ontwikkelingen in de lokale politiek rondom de gemeenteraadsverkiezingen van maart 1990, Zeist, 1991, p. 205-220.

Knippenberg, H. en B. de Pater, De eenwording van Nederland, Nijmegen, 1988.

Komito, L., Irish clientelism, A reappraisal, in: Economic and Social Review, 1984 (15), p. 173-194.

Korsten, A.F.A. en W. Kuiper (red.), Limburg kiest, Ontwikkelingen in de lokale politiek rondom de gemeenteraadsverkiezingen van maart 1990, Zeist, 1991.

Korsten, A.F.A., Het modeme Limburg, in: Korsten, A.F.A. en W. Kuiper (red.), Limburg kiest, Ontwikkelingen in de lokale politiek rondom de gemeenteraadsverkiezingen van maart 1990, Zeist, 1991, p. 11-54.

Korsten, A.F.A., W. Kuiper en F.P.C.L. Tonnaer (red.), Gemeentelijke herindeling, keuzen en kansen, Lessen uit Midden-Limburg, Zeist, 1991.

Kuiper, W., Verdwijnen van lokale lijsten is verlies voor democratie in Limburg, in: Namens, 1988 (3), p. 19-22.

Kuiper, W. en P.W. Tops, Local coalition formation in the Netherlands, in: Mellors, C. en B. Peijnenburg (red.), Political parties and coalitions in European local government, London, 1989, p. 220-239.

Kuiper, W. en E.T.C. Knippenberg. Het CDA en de lokale lijsten in Limburg, in: Bestuursforum, 1990 (14), p. 146-148. 
Kuiper, W. en K.L.L.M. Dittrich, Breukvlakken in het politieke landschap in Limburg, in: Korsten, A.F.A. en W. Kuiper (red.), Limburg kiest, Ontwikkelingen in de lokale politiek rondom de gemeenteraadsverkiezingen van maart 1990, Zeist, 1991, p. 55-67.

Kuiper, W., De spelers in de verkiezingsarena, in: Korsten, A.F.A. en W. Kuiper (red.), Limburg kiest, Ontwikkelingen in de lokale politiek rondom de gemeenteraadsverkiezingen van maart 1990, Zeist, 1991, p. 105-115.

Kuiper, W., M.FJ. van Tilburg en A.F.A. Korsten, Politieke verhoudingen voor en na de herindeling, in: Korsten, A.F.A., W. Kuiper en F.P.C.L. Tonnaer (red.), Gemeentelijke herin deling, keuzen en kansen, Lessen uit Midden-Limburg, Zeist, 1991,p. 51-73.

Kuypers, G., Grondbegrippen van politiek, Utrecht, 1973.

Laver, M., C. Rallings en M. Thrasher, Coalition theory and local government: Coalition payoffs in Britain, in: British Journal of Political Science, 1987 (17), p. 501-509.

Laver, M., Theories of coalition formation and local government coalitions, in: Mellors, C. en B. Peijnenburg (red.), Political parties and coalitions in European local government, London, 1989, p. 15-33.

Lawson, K. (red.), Political parties and linkage, A comparative perspective, New Haven, 1980.

Leijenaar, M. en B. Niemöller, Vrouwen in het lokaal bestuur, in: Derksen, W. en A.F.A. Korsten (red.), Lokaal bestuur in Nederland, Alphen a/d Rijn, 1985, p. 98-111.

Leijenaar, M. De geschade heerlijkheid, Politiek gedrag van vrouwen in Nederland, 1918-1988, dissertatie, Leiden, 1989.

Lijphart, A., Verzuiling, pacificatie en kentering in de Nederlandse politiek, Amsterdam, 1979 (derde druk, oorspronkelijk 1968).

Linden, $R$, van der en D. Ruijters, Limburg en de regionaal-economische politiek van de rijksoverheid, in: Soeters, J., H. Spoormans en R.G. Welten (red.), Het nieuwe Limburg, Herstructurering en ontwikkeling, Schiedam, 1990, p. 17-29.

Lokin, J., De invoering van het Burgerlijk Wetboek in het Hertogdom Limburg op I januari 1842, in: Luijten, E. e.a., 146 jaar Burgetlijk Wetboek, Deventer, 1989. p. 15-28.

Luykx, H., Andere katholieken, 1920-1960, in: Archief voor de geschiedenis van de katholieke kerk in Nederland, Nijmegen, 1987 (29), p. 52-84.

Mellors, C. en B. Peijnenburg (red.), Political parties and coalitions in European local government. London, 1989.

Ministerie van Binnnenlandse Zaken, De helft als minderheid, 's-Gravenhage, 1983.

Morlan, R.L., Gemeentepolitiek in debat, Opvattingen van burgers en bestuurders, Alphen a/d Rijn, 1974.

Mouriken, P., The demanding citizen: Diven by policy, self-interest or ideology? in: European Joumal of Political Research, 1987 (15), p. 417-435.

Mulder, M., Omgaan met macht, Amsterdam, 1977.

Nissen, P.J.A., Godsdienst en kerk in ontwikkeling, in: Soeters, J., H. Spoormans en R.G. Welten (red), Het nieuwe Limburg, Herstructurering en ontwikkeling, Schiedam, 1990, p. 297-325.

Nuyens, E., De staakkundige geschiedenis der provincie Limburg vanaf haar ontstaan tot aan haar uiteenvallen in 1839. Maastricht, 1956.

Ohlenforst, M.H.M., Democratie en dorpspolitiek, Lokale politiek in Echt tussen 1946 en 1990 , Sint-Geertruid, 1992.

Parker, AJ., A note upon localism and party solidarity, The transfer of votes in the Udaras na Gaeltachta election of 1979, in: Economic and Social Review, 1984 (15). p. 209-24.

Passchier, N., Katholieke ontzuiling, kerkelijke binding en context, Onderzoeksnotitie van het Instituut voor Sociale Geografie, UvA, Amsterdam, 1986.

Pennings, P., Verzuiling en ontzuiling, De lokale verschillen, Kampen 1991.

Poggi, G., Clientelism, in: Political Studies, 1983 (31), p. 662-667.

Prewitt, K., The recruitment of political leaders, A study of citizen-politicians, Indianapolis, 1970. 
Pridham, G., Coalitional behaviour in theory and practice; An inductive model for Western Europe, Cambridge, 1986.

Putten, J. van (red.), Haagse machten, Verslag van een politicologisch onderzoek naar de totstandkoming van acht regeringsmaatregelen, 's-Gravenhage, 1980.

Quanjel, M.M.H., Coalitievorming als continu proces, coalitiegedrag op lokaal nivo, Een stemanalyse van de gemeenteraden van Roermond en Sittard, stageverslag. Nijmegen, 1988.

Reerink, J. e.a., Honderd jaar over de rooien, De sociaal-democratie in Limburg van 1889-1988, Sittard, 1989.

Research en Marketing b.v., Analyse van het stemgedrag van de Limburgse kiezer bij de Tweede Kamerverkiezingen van 21 mei 1986, Heerlen, 1986.

Righart, H., De katholieke zuil in Europa, Het ontstaan van verzuiling onder katholieken in Oostenrijk, Zwitserland, België en Nederland, Amsterdam, 1986.

Rokkan, S., Eine familie von Modellen fur die vergleichende Geschichte Europas, in: Zeitschrift fur Soziologie, 1980 (9), p. 118-128.

Rochon, T. Local elites and the structure of political conflict, Parties, unions, and action groups in the Netherlands, dissertatie, Michigan, 1980.

Rooduijn, M., Politieke patronage in Zuid-Italië, Verdwijnen de heiligen uit het paradijs?, Nijmegen, 1986.

Rowley, C., The relevance of the median voter theorem, in: Journal of Institutional and Theoretical Economics, 1984, p. 104-126.

Sartori, G., Parties and party systems, A framework of analysis. Cambridge. 1976.

Sayari, S., Political patronage in Turkey, in: Gellner, E. en J. Waterbury (red.), Patrons and clients in mediterranean societies, London, 1977, p. 103-114.

Scott, J., Patron-client politics and political change in South-east Asia, in: American Political Science Review, 1972 (66), p. 91-113.

Scoth, J., Patronage or exploitation, in: Geliner, E. en J. Waterbury (red.), Patrons and clients in mediterranean societies, London, 1977, p. 21-39.

Silverman, S., Patronage as myth, in: Gellner, E. en J. Waterbury (red.), Patrons and clients in mediterranean societies, London, 1977, p. 7-19.

Soeters, J., H. Spoormans en R.G. Welten (red.), Het nieuwe Limburg, Herstructurering en ontwikkeling, Schiedam. 1990.

Soeters, J. en A.J.A. Felling, Het eigene van Limburg, in: Soeters, J., H. Spoormans en R.G. Welten (red.), Het nieuwe Limburg, Herstructurering en ontwikkeling, Schiedam, 1990, p. 277-296.

Spoormans, H., R.G. Welten en K.L.L.M. Dittrich, Politiek: deining in de electoraie stromen, in: Soeters, J., H. Spoormans en R.G. Welten (red.), Het nieuwe Limburg, Herstructurering en ontwikkeling, Schiedam, 1990, p. 326-348.

Stanyer, J., Understanding local government, Oxford, 1980.

Steunenberg. B., Ombuigingsbeleid en politieke besluitvorming, Een politiek-economische theorie. getoetst voor politie, Enschede, 1989.

Steunenberg, B., Coalition theories: Empirical evidence for Dutch municipalities, in: European Journal of Political Research 1992 (22), p. 245-278.

Suleiman, E., State structures ancl clientelism, The French state versus the 'notaires', in: British Joumal of Political Science, 1987 (17), p. 257-279.

Swaan, A. de, Coalition theories and cabinet formations, Amsterdam, 1973.

Thomassen, J J.A. (red.), Democratie, Theorie en praktijk, Alphen a/d Rijn, 1981.

Tilburg. M.F.J. van en M.H.M. Ohlenforst, De neergang van de opkomst: afgang van de politiek? in: Korsten, A.F.A. en W. Kuiper (red.), Limburg kiest, Ontwikkelingen in de lokale politiek rondom de gemeenteraadsverkiezingen van maart 1990, Zeist., 1991, p. 171-188.

Tilburg, M.F.J. van, Lokaal of nationaal?, Het lokale karakter van de gemeenteraadsverkiezingen in Nederlandse gemeenten (1974-1990), 's -Gravenhage, 1993.

Toonen, Th., Denken over binnenlands bestuur, 's-Gravenhage, 1987. 
Tops, P.W. en A.F.A. Korsten, Collegevormen in Nederlandse gemeenten 1970-1982, Amsterdam, 1984.

Tops, P.W. en A.F.A. Korsten, Het college van burgemeester en wethouders, in: Derksen, W. en A.F.A. Korsten (red.), Lokaal bestuur in Nederland, Alphen aan den Rijn, 1989, p. 128-143.

Tops, P.W., Afspiegeling en afspraak, Coalitietheorie en collegevorming in Nederlandse gemeenten (1946-1986), 's-Gravenhage, 1990.

Tops, P.W., Coalitievorming in communale gemeenten, in: Korsten, A.F.A. en W. Kuiper (red.), Limburg kiest, Ontwikkelingen in de lokale politiek rondom de gemeenteraadsverkiezingen van maart 1990, Zeist, 1991, p. 69-85.

Vellenga, S., Katholiek Zuid Limburg en het fascisme, Een onderzoek naar het kiesgedrag van de Limburger in de jaren dertig. Assen, 1975.

Venner, G., Inventaris van het archief van de familie De Heusch, later Van Scherpenzeel Heusch 1386-1895. Maastricht, 1989.

Vooren, F.W.C.J. van de en P.V.M. Hanraets, Het Limburgse herstructureringsbeleid, in: Soeters, J., H. Spoormans en R.G. Welten (red.), Het nieuwe Limburg, Herstructurering en ontwikkeling, Schiedam, 1990, p. 30-51.

Waterbury, J., An attempt to put patrons and clients in their place, in: Gellner, E. en J. Waterbury (red.), Patrons and clients in mediterranean societies, London, 1977, p. 329-342.

Welten, R.G., Nationalisering en professionalisering in de Limburgse gemeentepolitiek, De raadsverkiezingen van 1986 in perspectief, in: De Europese gemeente, 1986, nr. 6, p. 43-48.

Werkgroep Lokale politiek, Rijksuniversiteit Limburg, Lokale politiek in Limburg, Een menu met 69 variaties, Maastricht, 1986.

Wijnen, J. en Th. Kooprnanschap. Hoe katholiek is Limburg? Maasbree, 1982.

Zielonka-Goei, M.L., Uitzicht op de toekomst, De totstandkoming van verkiezingsprogramma's voor de Tweede Kamerverkiezingen van 1986, Leiden 1989.

Zijlstra, P. Herindeling en politieke partijen in de gemeenten Elsloo, Stein, Umond, Afstudeerscriptie, Hogeschool Katholieke Leergangen Sittard, 1989.

Zuckerman, A., Clientelist politics in Italy, in: Gellner, E. en J. Waterbury (red.), Patrons and clients in mediterranean societies, London, 1977, p. 63-80. 


\section{Curriculum vitae}

Wim Kuiper is in 1961 in Zwolle geboren. Hij voltooide in diezelfde plaats in 1979 de opleiding Atheneum- $\mathrm{A}$ aan het Carolus Clusius College en studeerde vervolgens tot 1986 bestuurskunde aan de Universiteit Twente. Eind 1985 trad hij als wetenschappelijk assistent in dienst bij de Faculteit der Rechtsgeleerdheid van de Rijksuniversiteit Limburg. Vanaf 1989 was hij bij deze faculteit werkzaam als universitair docent bestuurskunde in de vakgroep metajuridica en als secretaris van het Centrum voor Euregionale, provinciale en Lokale Studies (CELS). In 1990 werd hij lid van de gemeenteraad van Maastricht en in maart 1993 werd hij tot wethouder benoemd in deze gemeente. 